\title{
, $\therefore$.
} Hh . 0
$*$

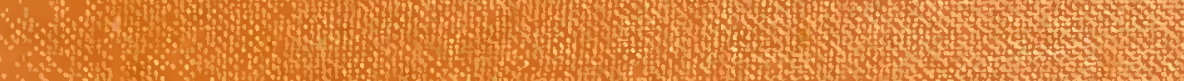
. 3. 8. - H.

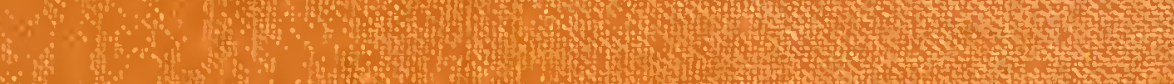

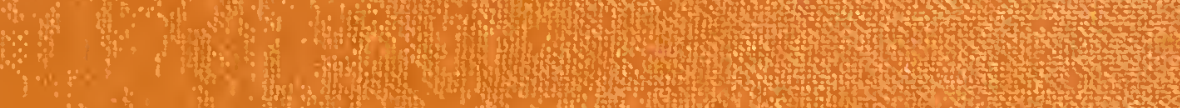
(3)

ato is
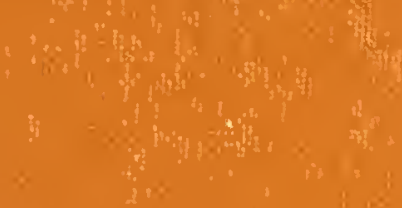

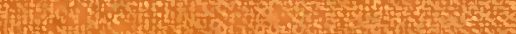

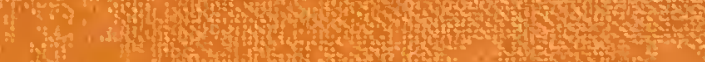
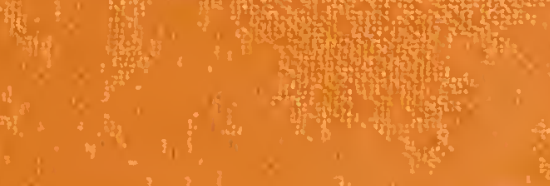

Hith the the
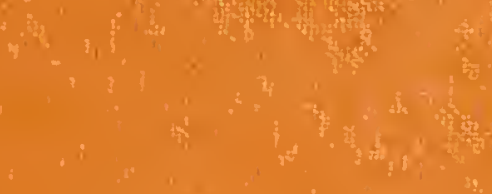

ir
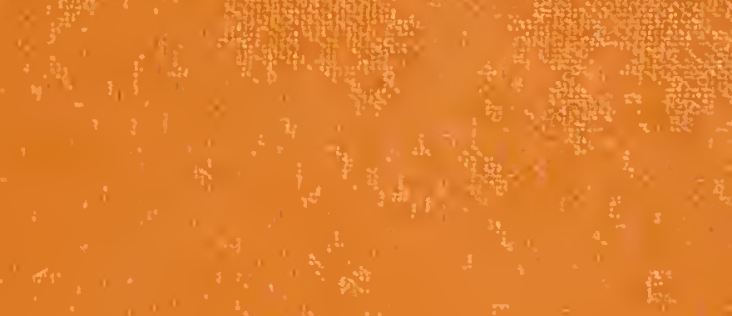

2.
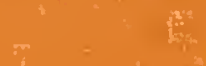

thes

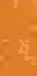

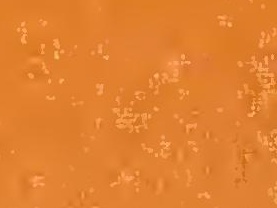
2. ?.
$\because \frac{1}{4}$
का?

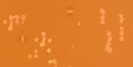

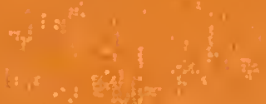

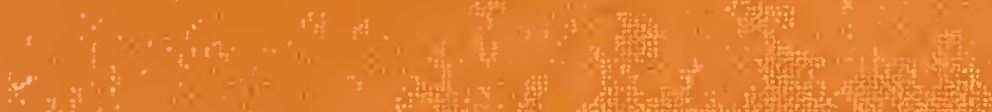

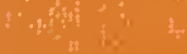

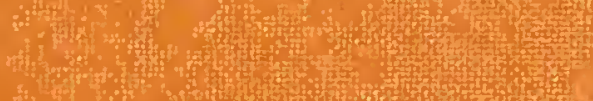

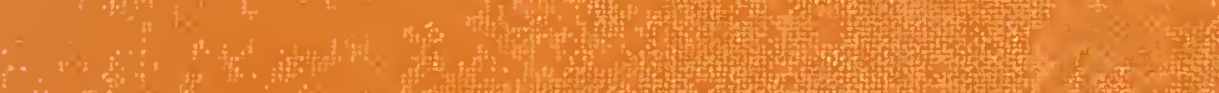

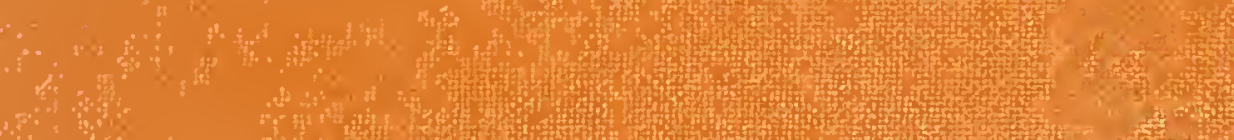
th

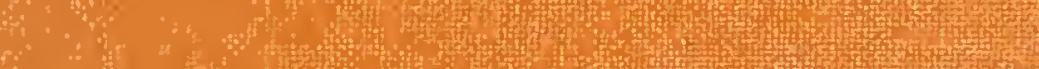
(4)

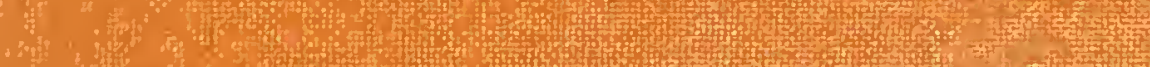
$: 40$ -

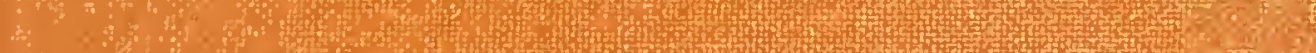
$\therefore \%$..

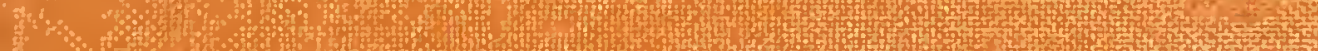
16.

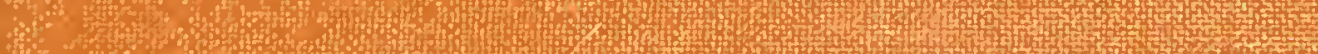
A O. 46. O. 


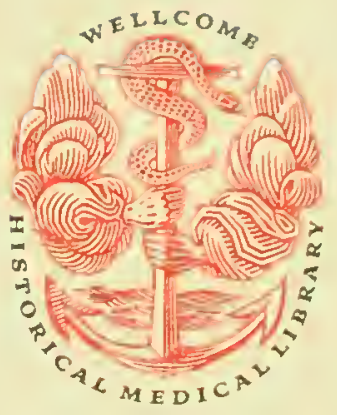

ACCESSION NUMBER

PRESS MARK 
Digitized by the Internet Archive in 2015

https://archive.org/details/b24875260 

ON THE

POPULAR NAMES OF BRI'ISII PLANIS. 



\section{ON THE \\ POPULAR NAMES}

or

\section{BRITISH PLANTS,}

RBING AN IXPLANATION OF THB

\section{ORIGIN AND MEANING}

OF THB NAMBS OF OUB

INDIGENOUS AND MOST COMMONLY CULTIVATED SPECIES.

BX

R. C. A. PRIOR, M.D.

FELLOT OF THE ROTAE COLLBGB OF PHYSICIANS OF LONDON, AND OF THE LINNEAN AND OTHBR BOCTETIPS;

TRANSLATOR OF "ANCIENT DANISH BALLADS."

THIRD EDITION.

\section{LONDON :}

FREDERIC NORGATE,

7. KING STREET, COVENT GARDEN;

WILLIAMS \& NORGATE, 20, FREDERICK STREET, EDINBURGH. 


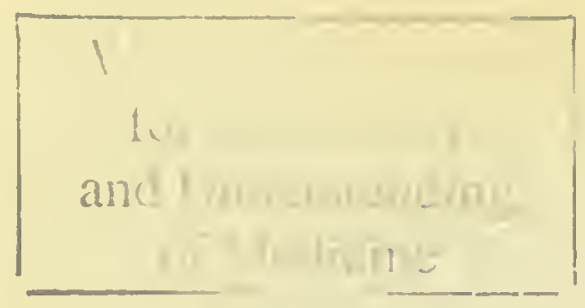

$$
\begin{gathered}
(2) \\
A Q, A M
\end{gathered}
$$

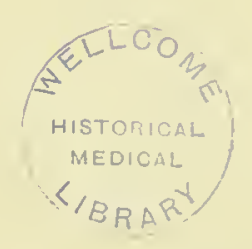


ADVERTISEMENT TO THE THIRD EDITION.

Ix publishing a new edition of this work, I beg to express my warmest thanks and my obligation to many friends, and to many correspondents not personally known to me, but more particularly to $\mathrm{Mr}$. Leo Grindon, of Manchester, and Mr. M. P. Edgrworth, and the Rev. J. C. Atlinson, for mueh valuable information that they have given me, and for the correction of several oversights and errors.

R. C. A. P.

Halse House, near Taunton, 1879. 



\section{N'TRODUCTION.}

THE authors of our several Floras, and other systematic writers, have been careful to translate the Greek and Latin names of our plants, and, as far as it is known, to explain their meaning, but have passed over the popular ones, as though the derivation of these were too obvious to require any notice. This is far indeed from being the case. Our excellent lexicons and Latin dictionaries enable us in most cases to understand the former with comparative facility, but in the very backivard state of English etymology, as exhibited in books of reference, it is impossible, without a great waste of time and trouble, to discover the real meaning of the latter; of those more particularly which date from an early period. It is the object of the following Vocabulary to supply the defect.

The Anglo-Saxon names, during the period of ncarly five hundred ycars that intervened betwcen the Conquest and the revival of botanical inquiry in the sixtecnth ccntury, had, the most of them, fallen into disuse, and been replaced with others taken from Latin and French, or transferred to plants to which they did not originally 
belong. 'They have probably been nearly all of then preserved to us in ancient manuscripts; but it is difficult to aseertain what werc the several plants that were meant by them. Indeed it is not likely that in earliel times any great number of our indigenous speeies liad been carefully distinguished. It is only when nations have arrived at a high state of culture, that they are curious about oljjects of Natural History, as such, or have special names for any but a fer of the more conspiciously useful, beautiful, or troublesome of them. Our fruit and timber trees, the cereal grains, and several potherbs and medicinal plants, have the same at the present day as they bore a thousand years ago; but by far the greater number of our other species have only sueh as have been given to them within the last three hundred years. 'These, for the most part, were introduced from abroad; for in the aceurate study of living plants the eontinental nations took the lead, and our own early herbalists did little more than aseertain which they meant, and apply their names to our orvn.

In the selection of these the father of English Botany, Dr. William Turner, set his suceessors a laudable example by lieeping as closely as possible to the Flemish and German, as languages more akin to our mother-tongue, and intelligible to the uncdueated, than Greek and Latin. Lyte in his excellent translation of Dodoens did the same, and was worthily followed by Gerarde, and by Parkinson. The works of later herbalists are little clse than transeripts 
of what was published by these four. Turner's Herbal eame out in three parts between 1551 and 1568; Lyte's in 1575 ; Gerarde's in 1597 ; a new edition of it by T. Johnson in 1632; and Parkinson's two works, his Paradisus Terrestris, and his Theatre of Botany, in 1629 and 1643. 'The Grete Herball, the Little Herbals, and Maeer's Herbal, Batman's Bartholomew de Glantvilla, and some other black-letter books of an earlicr date than Turner's, are of seareely any assistance to us, from the difficulty there is to diseover by their very inadequate deseriptions, what plants they mean. The aneient voeabularies published by Jos. Mayer and Wright, and by Halliwell and Wright, and others in the British Muscum* and foreign libraries, are, for the same reason, very soldom available. Some most valuable manuseripts have, sinee the first edition of this book, been published, with a translation and glossary, by the Rev. Oswald Cockayne, in lis "Anglo-Saxon Leeendoms," a work of great interest, and one to which reference is made in the following pages. There has also appeared the first part of a Dietionary of English Plant-names by Britten and Holland, a work compiled with industry and honesty from information received from almost every part of these islands, and in which even the local misspelling or misapplieation of any term is faithfully recorded.

'There are distinguished botanists at the present day who

- I have hero tho agrecablo duty of acknowledging the kindness of the late Mr. J. J. Bennett, the Curator of the Botanical collections, in most handsomely placing at my disposal many extracts from these mauuscripts, that bo had made for a similar undertaking. 
look upon popular nanes as leading to confusion, and a nuisance, and who would gladly abandon them, and ignore their existenee. But this is surely a mistake, for there will always be ladies and others, who, with the greatest zeal for the pursuit of Natural History, have not had the opportunity of learning Grcek and Latin, or have forgotten it, and who will prefer to call a plant by a name that they can pronounce and reeollcet. We need but to ask ourselves, what sueeess would have attended the exertions of the late exeellent and benevolent Professor Henslow among the little pupils of his village sehool, if he had used any names but the popular ones.

Besides, admitting to the full all that eau be urged against them from a purely botanical point of view, we still may derive both pleasure and iustraetion from traeing them back to their origin, and reading in them the habits and opinions of former ages. In following up such au analysis we soon find that we are travelling far away fiom the humble oceupation of the herbalist, and are entering upon a higher region of literature, the history of man's progress, and the gradual development of his eivilization. Some of the plants that were familiar to our aneestors in Central Asia, bear with us to this day the very names they bore there, and as distinetly intimate by them the uses to whieh they were applied, and the degrec of eulture whieh prevailed where they were given, as do those of the domestie affinities the various oeeupations of the primeval family. The names of 
animals, with which many are compounded, carry us still further back, or to still more distant regions; for in some cases it is impossible now to deduee any meaning from them at all, and it is probable that these names may have been adopted, with the knowledge of the animal, from an entirely alien nation. In such, for instance, as hound and $o x$, we have unquestionable proof that they must have been given to those animals, before the existing dialects of our ancient mother-tongue had assumed their distinctive form; and this must have been at an immensely remote point of timc. For to educe from the same language others so different from one another, not only in their voeabulary, but in their grammatical construction and declensions, as were already in their earliest known state the oldest of them with which we arc aequainted, the Sanskrit, Latin, Greek, and Gothic, required a period of not merely centuries, but millennia.

The most interesting, in this respeet, of the names that have eome down to us, are those which date from a time antecedent to the settlement of the German raee in England, names whieh are dedueible from Anglo-Saxon roots, and identical, with allowance for dialeetie peculiarities, in all the High and Low German, and Seandinavian languages, and, what is partieularly worthy of our attention, each of them expressive of some distinct meaning. These will prove, what with many readers is a faet ascertained upon other evidence, sueh as the contents of sepulclural mounds, traditionary laws, and various parallel researehes, 
that the tribes which descended upon Britain had entered Lurope, not as a set of savares, or wandering pastoral tribes, or mere pirates and warriors, but as colonists, who, rude as they may have been in dress and manners, yet, in essential points, were already a eivilized people. It will be secn at the same time that they must have come from a colder country; for while these names comprehend the Oak, Becch, Birch, Hawthorn, and Sloc, trees that extend far into Northern Asia, they do not comprise the Elm, Chestnut, Maple, Walnut, Sycamorc, Holly, or any evergreen, execpt of the fir tribe, or Plum, Pear, Pcach, or Cherry, or any other fruit-tree, except the Apple. For all thcse latter thcy adopted Latin names, a proof that at the time when they first came into contact with the Roman provincials on the Lower Rhine, they were not the settled inhabitants of the country they were then oceupying, but forcigners newly arrived there as colonists or conquerors from a country wherc those trees were unknown. It is remarkable that the early Greek writers make no mention of any German tribes, but represent the Scythians as the next neighbours of the Celts, and this differenee in the names of the one set of trees and the other, and the names which they adopted being Roman, and not Celtic, suggests that the Germans had come down from the north-east not very long before the Christian era, and intruded themselves, as a wedge, betwcen those two more anciently recorded nations.

There seems to be much misapprehension in respect to 
this great movcment of the Eastcrn raees which broke up the Roman cmpire. The subject is one into which it would here be out of plaee to enter fully, and it has becn largely treated by J. Grimm in his admirable Gesehichte der Deutschen Spraehe. But even in the following vocabulary we shall see evidenee of the continuous advance of a civilized race from the confines of India to these islands, and nothing indieative of a great rush from the North of wild hordes bent npon robbery and destruction, as it has bcen usually represented to have bcen. The gradual drying of the Caspian Sea left the interior of Asia more and more barren, the knowledge of the useful metals facilitated the conquest of the savages of the West, and it is likely that predatory bands of Huns and Turks and allicd nomadie nations aceelerated the movement by rendering the labour's of agrieulture less remuncrative. Thus the migration, being one that proeeeded from constantly aeting causes, extended over many centuries. Let us lay aside all prepossessions, and inquire what light is thrown by the following voeabulary upon the real state of the Germane tribes at that period.

In thesc mere names of plants, sctting aside all other sources of information, we diseover that these people eame from their home in the East with a knowledge of lctters, and the useful metals, and with nearly all the domestic animals; that they cultivated oats, barley, wheat, rye, and beans; built louses of timber, and thatched them; and, what is important, as showing that their 
pasture and arable land was intermixed, and acknowledged as private property, they hedged their fields and feneed their gardens. Cosar denies this; but the frontier tribes, with whom he was aequainted, were living under eertain peeuliar Mark laws, and were, in fact, little else than an army on its mareh. The unquestionably native, and not Latin or Celtie origin of sueh names as Beech and Hawthorn, or Oats and Wheat, proves that although nur aneestors may have been indebted to the provineials of the empire for their fruit-trees, and some other luxuries, for a knowledge of the fine arts, and the Latin literature, and a debased Christianity, the more essential aequirements upon which their prosperity and progress as a nation depended were already in their possession. Like the seattered lights that a traveller from the wilderness sees here and there in a town that lies shrouded in the darkness of night in a valley beneath him, and the oeeasional indistinet and solitary voiee of some domestic animal, that for a moment breaks the silenee, these distant eehoes of the past, these speeks that glimmer from its obseurity, faint as they are, and few and far between, assure us that we are eontemplating a seene of human industry, and peace, and eivilization.

In this respeet the inquiry is one of the highest interest. In another it is probable that some who eonsult these pages will be disappointed. The names have usually been given to the plants from some use to which they were applied, and very ferw of them bear any traee of poetry or 
romance. In short, our Sweet Alisons and Herb Truloves, our Heartseases, Swcet Cicelies, and Sweet Williams resolve themselves into sadly matter-of-fact terms, which arose from causes very different from the pretty thoughts with which they are now associated, and sometimes, as in the case of the Forget-me-not, were suggestive of very disagreeable qualities. In many cases, as in that of the hawkweed, the miltwaste, and the celandine, they refer to virtues that were ascribed to the plants from the use that birds and other animals were supposed to make of them. Many more have been given to them in accordance with the so-called doctrine of signatures. This was a system for discovering the medicinal uses of a plant from something in its external appearance that resembled the disease it would cure, and proceeded upon the belief that God had in this manner indicated its especial virtues. Thus the hard stony seeds of the Gromwell must be good for gravel, and the knotty tubers of Scrophularia for scrofulous glands; while the scaly pappus of Scabiosa shorved it to be a specific in leprous diseases; the spotted leaves of Pulmonaria, that it was a sovereign remedy for tuberculous lungs; and the growth of Saxifrage in the fissures of rocks, that it would disintegrate stone in the bladder. For, as Wm. Coles tells us in his Art of Simpling, ch. xxvii : "Through Sin and Sathan have plunged mankinde into an Ocean of Infirmities, yet the mercy of God which is over all his workes, maketh Grasse to grow upon the Mountaines, and Herbes for the 
use of men, and hatl not only stamped upon them a distinct forme, lut also given them particular Signutures, whereby a man may read, cven in legible characters, the use of them."

Other names we shall find relate to the eeonomical uses to which the plants were once applicd. Some few are descriptive; some refer to the legrends or the ccremonies of the Roman Catholic Church; some to the clegant mythology of the Greeks; some to a vulgar joke. In thinking over these names, and the antiquated notions that they represent, we are led at every moment to recall the times from which they date, to pieture to ourselves the living figures of our ancestors, to hear them spealing their obsolcte dialcet, and almost to makc the weeds that shadow their grave tell more than their tombstonc of its sleeping inhabitants.

The terms with whieh we have to deal may for convenience be referred to tro groups, as Germanic, or Romanic. To the former belong such as are of AngloSaxon, German, or Low Germall, or Scandinavian origin, and to the latter such as are French, or derived from other forms of debased Latin, including a few adopted into it from the Arabic. When a word falls within the first group, we find great assistance in Dr. Bosworth's and J. Jamieson's Dietionarics, and in the works of Adelung, Bopp, Pott, Diefenbaeh, and the brothers Grimm, and in those of the Frisian and Seandinavian writers. French words, from the loss of those Ccltie dialects with which 
the Latin element of the language was eorrupted, and the extreme degree of debasement to which it has arrived, are of much more diffeult analysis. For these we have the assistanee of Diez's Wörterbueh der romanisehen Spraehen, Scheler's Dietionnaire d'Etymologie Française, the Dietiounaire etymologique of $\mathrm{A}$. Braehet, and the eopious Dietiomaire de la Langue Française of Littré. A large number of the names referable to this group have been adopted from the Latin of the Middle Ages, a jargon that, with many peeuliarities in each eountry, was at one period used all over the West of Europe, and is explained in the great Lexieon Medire Latinitatis of Dueange. These names, obseure as they often were from the first, have been so eorrupted by ignorant eopyists as in many eases to defy all analysis, and render it neeessary to refer to old rocabularies, eatalogues, and herbals to diseover their meaning. We might have expeeted many to have been derived from the language of the aneient Britons; but, as far as I am aware, "Maple" is the only one; and there are very few indeed that have been adopted from the modern Welsh, or from the Erse or Graelie.

As the term "Ind-European" will be frequently used, and some may refer to the following voeabulary who have not entered into philologieal speeulations of this kind, it is neeessary to mention that the analysis of words, and the omparison of their roots and grammatical structure, have proved that all the prineipal languages of alphabetieal literature, exelusive of the Arabie and its allies, are inti- 
mately eomneeted with the aneicnt dialects of Persia and Northern India. 'This has been eonsidered by many writers as a proof that all the nations which speak them have deseended from a eoinmon stock, and although this inferenee as to the people may be ineorreet, still, in a philologieal point of view, we may treat the languages as sister deseendants of some Asiatic parent which has long since perished, and rank with them sueh other dialects as agree with these in their roots and strueture. Under"Ind-European," then, will be eomprised Sanskrit and Zend, and all the Indian and Persian dialeets that are related to them; Greek; Latin, and its modern varieties; Celtie; Gothic, and all the other Germanie and Seandinavian dialeets; Lithuanian, and Slavonian; but not Basque, Lapp, Finn, DIagyar, or Turkish. The language of the Indian Vedas, as the oldest existing member of the family, is that to whieh linguists refer in searehing for the roots of words of this elass, itself no more than the representative of another still more aneient one, whieh is utterly lost.

In order to avoid a long word, and for no other apparent reason, it has been proposed of late to supersede the rery expressive and most unobjectionable term of "Indo-" or "Ind-European," and to substitute for it that of "Aryan," which it is to be hoped will not be generally adopted. For, as well as this may apply to a few Asiatic dialects, it is

* I have ventured in this word to omit the 0 , as is done in other rords similarly forned from Greek and Latin; e.g. magnanimous, philanihropy, and neuralgia, which are never written magno-animous, philo-anthropy, and neuro-algia. 
only by violently wrenching words from their proper meaning, that it can be extended to the European members of the group. It is perhaps an even stronger objeetion to its usc that some of the most distinguished philologists of the day have applied it specially to thesc Asiatic languages in contrasting them with the European. Thus L. Diefenbach, Or. Eur. p. 34:

"Ihre bciden stämme in Asien: der Indische und der Iranische, der wahrseheinlichst eingt anch im östlichen Europa hauste, ritt, und fuhr, bilden sämmtlichen Europäischen gegenüber eine gruppe die wir die Arische nennen."

Other terms, such as "Japetic," "Indo-Germanic," and "Caucasian," are too vague, or too limited.

But independently of the etymology of the names taken by themselves, the question is ever arising, why they should have bcen affixed to eertain plants. Wherc old writers are quoted, and they give the reason for those that they have themselves imposed, their authority is, of eourse, conclusive; but in other eases their notions are often fanciful, and must be accepted with great reserve; for old as are the writers and thcir books, relatively to modern botanists and floras, the names that they interpreted were often older than thcy, and the original meaning of them forgotten. Synonyms in foreign languages, including the Latin, arc of essential service, but neither are thesc very trustworthy; for authors, mistaking the sense of some unusual or obsolete word in one language, lave often translated it wrongly into another; and this is 
a fault that was as often made in ancient as in modern times; so that it is quitc impossible to reeoncile wlut is said of certain plants by Greck and by Latin writers. In the case of the Hyacinth, Violet, Anemony, and other conspieuous flowers mentioned by 'Theocritus as Sicilian plants, this is the morc extraordinary, as the flora of that island is very similar to the Italian, and from its vicinity might have been familiar to Italian pocts. But wo find cren in our own small island, that, what a Scotchman calls a "Bluebcll," and makes the subjeet of popular songs, is a totally different flower from the English Bluebcll.

It is this vague and random way of applying the same name to very different plants that occasions the greatest difficulty in the attempt to discorer its original meaning. Who would dream that the Privet, for instanee, has obtained a name indieative of "early spring" from having been confused under "Ligustrum" with the Primrose? or that the Primrose has borrowed its name from the Daisy? Numberless blunders of this kind arose while the art of describing a species was as yet unknown, and learned recluses, instead of studying nature in the fields, were perplexing themselves with a vain attempt to find in the north of Europe the Mediterranean plants of Theophrastus and Dioscorides. Indeed it was not till the publication of Turner's Herbal in the sixtcenth century, that there was any possibility of ascertaining with certainty, through any English work, which of several speeies, or, indeed, which of several genera, might 
be meant by any given name; and, as it would be mere waste of time to attempt it now, the following vocabulary will eontain, with the exception of a few from Chaucer and Gower, none but sueh as have been in use sinee that period.

Under the head of Popular Names our inquiry will eomprise those of the species most commonly cultivated in this country, as well as those of the naturalized and indigenous oncs, but not Gardeners' or Farmers' names of mere varieties. Provineial words, that have not found their way into botanical works, are, with a very few exeeptions, omitted. Many of thesc are very ancient, and expressive, and good names, and curiously illustrative of habits and superstitions that are rapidly passing away; but the study of them must be left to the loeal antiquary. They seem, generally, to be traceable to the language of the race which settled in the district where they prevail, and much less than the book names to a French or Latin souree. In the northern counties and Scotland the nomenelature is very essentially different from that of the middle and south of England, and contains many words of Norse origin, and many of Frisian; but unfortunately these have been so vaguely applied, that nobody linows to what plants they, any of them, properly belong. 'This is more particularly the ease with Seotch names. "Gowan," for instance, whieh in our English editions of Robert Burns is explained for us as "the daisy," means in different parts of Scotland many different plants, whieh agree 
in notling but the having a yellow flower." In Devonshire and the west of Somersetshire, there is also much that is peeuliar, and, apparently, continued from the Anglo-Saxon period. In Suffolk, too, there has leeen a rreat number of valuable old names preserved, and carefully reeorded in the Voeabularies of Moore and Forloy. Many that are familiar to us in aneient herbals and in old poetry, have long fallen into disuse, except as they oeeur in the names of villages, and surnames of fumilies, sueh as the plaees beginning with Gold, the ancient name of the marigold; as Goldby, Goldham, Goldthorpe, Goldsbury, and Goldworthy; and the families of Arnott, Sebright, Boughtflower, Weld, Pettigrew, Lyne, Spink, and Kemp. Those of the eommonest plants are the most variable, as the rarer ones have attraeted too little of popular notiee to have any but sueh as are given in books.

It seems desirable that these old wames should be preserved, but there is already mueh greater diffieulty in obtaining a eorrect list of those of any partieular distriet, and the meaning of them, than there was a generation ago, from the dying out of the raee of herb-doctors, and of the simplers, generally females, who used to eolleet for them. It is doubtful, indeed, whether any one of this

* The Cleroland dialect of Yorkshire, a dialcct almost purcly Torse. has been most carefully investigated by tho Rev. J. C. Atkinson in a work that is a model of accurate research, and should form a basis upon which to construct a more general glossary of the language of tho North-Humbrian couties. 
class could now be found, who has learnt them from tradition, and independently of modern books.

One of the last was about nincty years ago living at Market Lavington in Wiltshire, a genuine old-fashioned speeimen of his class, a Dr. Batter. He was understood to liave liad a regular medical education, probably as an apothecary, and eertainly enjoyed a very high reputation. He has been described to me by a physician who knew him well, the late Dr. Sainsbury, sen., of Corsham, as a most unpretending man, and a sueeessful practitioner, and visited and consulted from all parts of the county. He liad been brought up very humbly, and lived and dressed as a poor man in a eottage by the roadside, where he was born, and where his father and grandfather had lived before him, and been famous in their day as bonesetters. There, if the weather permitted, he would bring out his chair and table, and seat his numerous patients on the hedgebank, and preseribe for them out of doors. It is said that, being well acquainted with every part of the county, he would usually add to the names of the plants that he ordered, the loealities near the home of his visitor where they would most readily be found.

There were probably up to the end of the last century many such persons in other parts of England, eombining the trades of herbarist and apothecary, and humbly supplying the plaee of those "gentlewomen" for whom Gerarde wrote his Herbal, and of the kind and eharitable nuns of an earlier time. They were people of very humble 
or no edueation, and we might be tempted to suppose that we owe the absurd names we find in the following cataloguc to their ignorance and credulity. This is not at all the casc. Pcople in that rank of life seldom or never originate anything. Popular plant names, quitc as mucl as popular tales, superstitions, ballads, and remedies, arisc with a highcr and morc erlucated elass of society, and merely survive in a lower, after they have clsewherc bccome obsolete. We ean scarcely rcad without a smilc of scorn the meaning of such names as Fumitory, Devil's bit, Consound, and Cclandine; but it is to men of great celebrity in their day, to Greek and Latin writers, such as Theophrastus, Aristotle, Dioscorides, and Pliny, to Arabian physicians, the most aecomplished men of their time, and to the authors and translators of our early herbals, that we are indebted for ncarly all such names as these. TWe are not to criticize them, or attempt to cxplain them away, but honestly to trace them back to their origin, and in doing so to bear in mind, for our own humiliation, that those who have betrayed such astonishing ignorance and superstition, passed in their day for philosophers and men of letters. 


\section{WORKS REFERRED TO.}

Aasen, J. Ordbog. o. d. Norske Folkesprog, 1850.

Adclung, J. C. Wörterbuch, 1775 .

Apulcius, L. De herbarım virtutibus, Basil, 1528.

Atkinson, J. C. The Clereland Dialect, 1868.

Batman's Bartholomew de Glantvilla, 1582.

Banhin, Casp. Prodromus Theatri Botanici, 1620.

, De plantis a Sanctis nomen habentibus, 1591.

Bauhin, J. Historia Plantarum, 1650.

Beckmann, J. A. Lexicon Botanicum, 1801.

Bopp, F. Comparative Grammar, 1862.

Bosworth, J. Anglo-Saxon Dictionary, 1838.

Brachet, A. Dictionnaire Etymologique, 1870.

Britten and Holland. English Plant Names, 1878.

Brunsfclsins, O. Norum Herbarium, 1531.

Brunschwygk, H. De arte distillandi, 1500.

Clnsius, C. Plantæ rariores, 1601.

Cockayne, O. Leechdoms, 1864-6.

Coghan, Th. Haren of Health, 1584.

Coles, W. Adam in Eden, 1657.

Art of Simpling, 1656.

Constantini, Rob. Dictionarium abstrusorum vocabulorum, 1573.

Cordus, E. In Dioscoridem, 1549.

Diefenbach, L. Lexicon Comparativum, 1851.

Origines Europaea, 1861.

Diez, Fr. Etymologisches Wörterbuch, 1861.

Dodonæus, R. Stirpium Historia, 1583.

Douglas, Gavin. Virgil's Eneis, 1720.

Du Bartas, Divine Weekes, by Sylrester, 1611.

Du Cange, C. Glossarium Mlcdix Latinitatis, 1840-50, new ed. 7 rols. Ato.

Du Chesne, E. A. Les Plantes Utiles, 1846.

Erelyn, J. Silva, 1786.

Fuchs, L. Historia Stirpium, 1542.

Garnett, R. Philological Essays, 1859.

Gcraide, J. Herbal, 1597.

" ed. Th. Johnson, quoted as Ger, em., 1 C36.

Gesner, C. De Lunariis herbis, 1668. 
Glantvilln, Bar, by J. Trovian, lisis; ; Jy Jatman, 158\%.

Grafi, E. G. Althochdoutscher Sprachechatz, 1834.

Gray, S. F. Natural Arrangement, 1821.

Groto Herball, by Trovisa, 1526, and 105j1.

Grimm, J. Gesch. d. Dontsehon Sjurache, 1848.

$"$ J. and W. Doutsches Wörterbuch, 1854-79.

Halliwell, J. O. Archaic Dictionary, 185 5.

Hampson, R. 'T. Medii xevi Kalondarium, 1841.

Herbarius, 1528.

Hill, J. Herbal, 1755.

Hogg, J. On the Classical Plants of Sicily, in Hooker's Journal, 1834.

Holmbeo, C. A. Dot Norske Sprog, 1852.

Honnerat, S. J. Dict. Provençal-Fran çais, 1846.

Hyll, Th. Arte of Gardening, 1586.

Isiderus Hispalensis, de Etymologia, Migne's ed. 1850.

Jacob, E. Plantæ Favershamenses, 1777.

Jamieson, J. Scottish Dictionary, 1846.

Jennsen-Tusch, H. Folkelige Plantenarne, 1867.

Johnston, G. Botany ef Eastern Border, 1853.

Kent, Miss Flera domestica, 1823.

"

Sylvan Sketchcs, 1825.

Keogh, W. Botanelogia Hibernica, 1735.

Köne, J. R. Heljand, 1855.

Langham, W. Garden of Health, 1633.

Lightfoet, J. Flera Scotica, 1792.

Littré, E. Dict. de la langue Française, 1863-78.

Lobcl, M. Kruydtboek, 1581.

Lovell, R. Complete Herbal, 1665 .

Lupton, Th. A Thousand Notable Things, 1595.

Lyte, H. Niewe Herbal, 1578.

Macer, Am. De Virtutibus Herbarum, Basil, 1527 and 1581.

Mätzner, E. Alt-Englische Sprachproben and Wörterbach, 1878.

Matthioli, P. A. Comm. in Dioscoridem, Ven. 1554.

" Epitome aucta a Camerarie, Frankf. 1586.

Mayer and Wright. National Antiquities, 1857.

Menzc], C. Index Nominum Plantarum, 1682.

Milne, Colin. Indigeneus Botany, 1793.

Menc, F. J. Quellen und Forschungen, 1830.

Nares, R. Glessary, 1859.

Nemnich, P. A. Nomenclater multilinguis, 1793-98.

Newten, Th. Herbal to the Bible, 1585.

Ortus Sanitatis, by Cuba, 1486.

Outzen, N. Gloss. d. Friesischen Sprache, 1837.

Parkinson, J. Paradisus Terrestris, 1656. 
Plinius Secundus, Historia Naturalis, ed. Sillig, 1851.

Pott, A. F. Indogormanische Sprachen, 1853.

Promptorium Parvalorum, ed. Way, 1843-51.

Randolph, Frero. Slonne MS. in Brit. Mus. No. 3549, 1.

Ray, J. Synopsis Stirpium, 1724.

Regimen Sanitatis Salernitanum, ed. A. Croke, 1830.

Ruellius, J. De Natura Stirpium, 1724.

Schade, O. Altdentsches Wörtorbuch, 1866.

Scheler, A. Dict. d'Etymologie Française, 1862.

Sharrock, R. History of Vegetables, 1660.

Skinner, S. Etymologicon, 1671.

Smith, W. Dictionary of the Bible, 1863.

Stephanus, C. De re hortensi, 1536.

Stockholm Medical MS. of 14th century, in Archæologia, vol. xxx.

Stratmann, F. H. Dictionary of Old English, 1873.

Tabernæmontanus, J. T. Kraüterbuch, 1613.

Talbot, H. F. English Etymologies, $18+7$.

Threlkeld, C. Stirpos Hibernicæ, 1727.

Tonrnefort, J. P. Institutiones Rei Herbariæe, 1719.

Tragus, H. De Stirpibus, 1552.

Turner, R. Botanologia, 1664.

Turner, W. Libellus de re Herbaria, 1538.

, Herbal, 1551-68.

, Names of Plants, 1548.

Ulfilas, ed. Massmann, 1857.

Wedgwood, H. English Etymology, 1859-62.

Westmacott, W. Scripture Herbal, 1694.

Winning, W. B. Manual of Philology, 1838.

Wright, Th. Domestic Manner's in the Middle Ages, 1862.

" and Halliwell. Reliquire Antiqure, 1841-3. 


\section{ABBREVIATIONS OF IAANGUAGES.}

$\begin{array}{ll}\text { Ar. } & \text { Arabic. } \\ \text { Arm. } & \text { Armenian. } \\ \text { A.S. } & \text { Anglo-Saxon. } \\ \text { Boh. } & \text { Bohemian. } \\ \text { Bret. } & \text { Breton. } \\ \text { Da. } & \text { Danish. } \\ \text { Du. } & \text { Dutch. } \\ \text { Er. } & \text { Erse or Old Irish. } \\ \text { Est. } & \text { Esthonian. } \\ \text { Fin. } & \text { Finnic. } \\ \text { Fl. } & \text { Flemish. } \\ \text { Fr. } & \text { French. } \\ \text { Fris. } & \text { Frisian. } \\ \text { Gael. } & \text { Gaelic of the Highlands. } \\ \text { G. } & \text { German. } \\ \text { Go. } & \text { Gothic of Ulfilas. } \\ \text { Gr. } & \text { Greek. } \\ \text { Heb. } & \text { Hebrew. } \\ \text { Ic. } & \text { Icelandic. } \\ \text { It. } & \text { Italian. } \\ \text { L. or. Lat. Latin. } \\ \text { Lap. } \quad \text { Lappish. } \\ \text { Lith. } \quad \text { Lithuanian. } \\ \text { L.Ger. } \quad \text { Low German, Platt- } \\ \text { II.Gr. } \quad \text { Modern Greek. } \\ \end{array}$

$\begin{array}{ll}\text { M.Lat. } & \text { Mliddleage Latin. } \\ \text { Norw. } & \text { Norwegian. } \\ \text { O.F. } & \text { Old English of the 12tl. } \\ & \text { 13th, and 14th centuries. } \\ \text { O.Fr. } & \text { Old French. } \\ \text { O.H.G. } & \text { Old High German. } \\ \text { Off.L. } & \text { Officinal Latin. } \\ \text { O.N. } & \text { Old Norse, the ancient } \\ & \quad \text { Danish. } \\ \text { O.S. } & \text { Old Saxon of Lower Ger- } \\ & \quad \text { many. } \\ \text { Pers. } & \text { Persian. } \\ \text { Pol. } & \text { Polish. } \\ \text { Por. } & \text { Portnguese. } \\ \text { Rus. } & \text { Russian. } \\ \text { Skr. } & \text { Sanskrit. } \\ \text { Scot. } & \text { Scotch of the Lowlands. } \\ \text { Slav. } & \text { Slaronian. } \\ \text { Sp. } & \text { Spanish. } \\ \text { Sw. } & \text { Swedigh. } \\ \text { Tar. } & \text { Tartar. } \\ \text { Wal. } & \text { Walachian. } \\ \text { W. or Tel. Welsh. } \\ \text { Zend. } & \text { The old language of Per- } \\ & \text { sia, probably the Mede } \\ & \text { dialect. } \\ \end{array}$




\section{NAMES OF BRITISH PLANTS.}

Aaron, a corruption of L. arum, Gr. ápov, into a more familiar" word,

A. maculatum, $\mathrm{L}$.

Abete, Du. abeel, in Pr. Pm. awbel or ebeble, from Fr. aubel, M. Lat. albellus, whitish, a word that occurs as the name of the tree in Lambertus Ardensis, p. 79 : "Albellus cum tilia juxta crucem, ubi plantata est ad peregrinatorum requiem et præsidium," and which refer's to the white colour of the twigs and leaves. Our Abele is this Dutch name, abeel, with whieh it was introduced from Holland in Evelyu's time (Silva, 1. 207). Populus alba, L.

Acacra, Gr. ảкăkıa, gruilelessness, good nature; a name given by Dioscorides (b. i. ch. 130) to a small Egyptian tree, but now transferred in popular language to an American Robinia,

R. Pseudaeaeia, L.

Acri, Fr. ache, the old name of parsley, from L. apinu, formed by the ehange of $p i$ to ch, as in sapiam to sacke, propius to proche, etc., now only retained in Smallage, the small ach, Fr. ache de marais, ache rustique, ache femelle, as contrasted with the Alexander, Fr. ache large, grande ache, Apium, L.

Acosire, derived by Thcophrastus from the village 'Akoval. but by Ovid (Met. vii. 4.19) from growing upon rock, ùкoй,

"Quæ quia nascuntur dura vivacia caute, Agrestes aconita vocant."

Pliny suggests that it is so called from growing where 
there is no lust, $a$, not, and roves, dust, "nullo juxta ne pulvere quidem nutriente." It is, ratlice, a word of the same derivation, but used in a different sense, ákovitov, without a strugglc, alluding to the deadly virulence of its juice, which W. 'Turner says "is of all poysones the most hastie poysonc." The plant of the Greek writers lias been identified with the monkshood,

\section{Aconitum Napellus, L.}

"WinTER-, Eranthis hyemalis, DC:

Adden's TOngue, from the Du. adterstong, in old MSS. called nedderis gres (grass) and nedderis-tonge, MI. Lat. serpentaria, from its spikc of capsules having some fancied resemblance to that reptile's tongue,

Ophioglossum vulgatum, L.

ADDERwonT, the suakeweed or bistort, from its writhed roots, Polygonum Bistorta, L.

AfFady, M. Lat. affodillus, from L. asphodelus, Gr. cं $\sigma \phi \delta \varepsilon \lambda \circ s$, pietured in Ort. Sanit. as an Iris, an old term replaced in later times by Daffodit,

\section{Nareissus Pseudonarcissus, L.}

Agaric, L. agarieon, G. ảyapekov.

Agrimony or Egremony, in Chancer egremoine, L. agrimonia, a word of uncertain origin, probably the Gr. a $p \gamma \epsilon \mu \nu \eta$; but what this plant was, or why it was called so, is unknown. A. Eupatorium, L.

„ HeMp-, from its being confused under the name of Iinpatoria with the preceding species, and the resemblance of its learcs to those of hemp, Eupatoria cannabina, L.

Albespyne, in old works the name of the white- or haw-thorn, from the whitencss of its rind as contrasted with that of the black-thorn, Fr. aubespine, L. alba spina, as in Ovid (Fist. 1. vi. 165):

"Virgaque Janalis de spina sumitur alba."

Cratregus Oxyacantha, L.

Alder, formerly, and still locally, and more properly, 
Alten, A.S., clr, alr, aler, with a $d$ inserted for euphony, as in alderfirst, alderlast, Go. erila, whenee G. erle, O.H.G. elira, L. alnus. Garnett would eonneet it with words implying moisture, as uligo, ulva, ete. (Phil. Ess. p. 30). The similarity of the Danish elle with the name of fairies in that language, elle-trai, and elle-folk, has misled Goethe to give the name of erlen-kinig to the fariry-king. There is no etymologieal eonneetion between the two.

\section{Alnus glutinosa, L.}

, Black-, or Berry-BeAring-, a buekthorn that was wrongly assoeiated by the older botanists with the alder, but distinguished from it by bearing berries,

Rhamnus Frangula, L.

AlEcost, from L. costus, some unknown aromatie, and ale, so ealled from its having formerly been esteemed an agreeable aromatie bitter, and mueh eultivated in this country for flavouring ale. "Put eertaine handfuls of this herbe in the bottom of a vessel, and tumne up new ale upon it." Coghan (eh. 71.)-See Costurary.

Balsamita vulgaris, $L$.

ALE-HOOF, ground-ivy, from ale, and hoof, whieh appears to be the A.S. hufe, erown, Du. huif, O.N. hufa, and to have been given to this plant either as translating its $\mathrm{Gr}$. and Lat. names $\sigma \tau є \phi a \nu \omega \mu a$ $\gamma \eta s$, corona terrce; or in allusion to the ehaplet that erowned the alestake at a public-house, as in Chaueer (Prol. 1. 667):

\section{"A gerlond hadde he sette upon his heed,} As gret as it were for an alc-stake."

J. and $W$. Grimm would regard it as a eompound of ei, ivy, and loof, leaf, but, as we shall see under Ivy, the bush has been so named from the herb, and not the herb from the bush.-See Gir.t.

Nepeta Gleehoma, Benth.

Alexanders or Alisanders, the horse-parsley, fiom its ILatin specifie name Alexandrinum, a name that Ray says was given to it from its being a plant of Alexandrin in 
Egypt, but more probably derived from an earlier name, Petroselinum Macedonicum, a parsley of Macedon, Alexinder's country.-Dee Dodoens, p. 697.

Smyrnium Olus atrum, Is.

Alisson or Alison, L. Alyssum, from Gir. $\dot{a}$, not, and $\lambda \nu \sigma \sigma \eta$, maduess, a plant called so by the ancients, because, "ts 'Turner says, "it helpeth the biting of a worl dorgre." Tle seems, by his description of it, to mean the field madder, Sherardia arvensis, L. a very different plant from that which now bears the name. That of modern botanists is a genus of Cruciferx,

, SWEEr-, from its seent of honey,

Alyssum, L.

A. maritimum, $\mathrm{L}$.

AlKinet, Fr: orcanette, a dim. formed from It. and Sp. alcana, representing the Arabic $E l$ or Al hame or canne, the name of a very different plant, the Lawsonia inermis, $\mathrm{L}$. which yields, like the alkanet, a red dye, the IIenna of the harems,

$$
\text { "Bastard-, Lithospermum arvense, } \mathrm{L} \text {. }
$$

Alkekengi, from the Arabic, Physalis Alkeliengi, L.

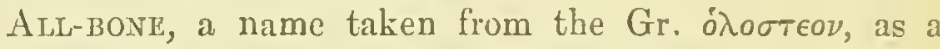

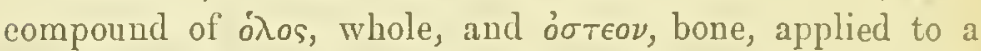
very tender plant, "whereof," says Gerarde, "I see no reason, unlesse it be by the figure called Antonomia; as, when we say in English, 'Hc is an honest man,' our meaning is, "He is a kllave." The ónooreov of Dioscorides was some other, probably, very different plant, the name of which has been transferred to this from its jointed skeleton-like stalks. In Cheshire it is ealled "Breakbones" from their snapping off at the joints.

Stellaria Holostea, L.

Alielujah, see Haldetujah.

Allgood, Du. algoede, G, allgut, from a Latin name tota bona, Fr. in Cotgrave and Palsgrave toutte bonne, given in old works to a groosefoot, that is otherwise called "Eng- 
.lish Mercury," on account of its excellent qualities as a remedy aud as an eseulent; whenec the proverb :

"Bc thou sick or whole, Put Mercury in thy koole."

Coghan (ch. 29).

Chenopodium Bonus Henricus, $\mathrm{l}$.

Alti-heal, see Clown's All-heal.

AlL-SEED, from the great quantity of its sced,

Radiola Millegrana, Sm.

and also

Chenopodium polyspermum, L.

and

Polycarpon tetraphyllum, L.

Alsike, Sw. alsike-kilöver, a clover so called from its growing abundantly in the parish of Alsike near Upsal in Sweden (J. H. Lunden in N. and Q.)

Trifolium hybridum, L.

Ausdou, from the Fr., a word of uncertain derivation, Polyporus fomentarius, igniarius, and dryadeus, Fries.

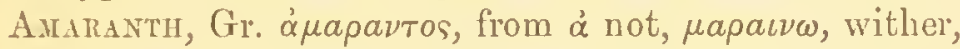
a word of not unfrequent oecurrence in Milton and other poets, as a vague name for some unfading flower. The original species was one that, from its quality of reviving its shape and colour when wctted with water, was much used by the ancients for winter chaplets. The phrase in St. Petcr's 1st Epis. ch. v. 4, "a crown of glory that fadeth not away," is in the original, "the amarantine erown of

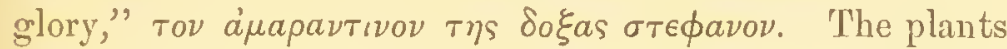
which botanists call so are the specics of the genus to which the "Love lies bleeding" belongs. " Amarantus, L.

Ambrose, a name given in old writings to some swectscented herb, from Gr. $\alpha \mu \beta \rho o \sigma \iota a$, the food of immortals, Skr. anrita, clixir of immortality, from $a$, not, and mri, Lat. mori, dic. It is uncertain what plant was meant by the Greek term, but whatever this may have bcen, Matthioli tells us in his Comment on Dioscorides, (1. iii. c. 12 ,) that it was ealled so by the aneients, becansc at continued use of it rendered men long-lived, in the 
same way as the Ambrosia, which was the food of the. Gods, was fabled to preserve them immortal. The Moors (see Hooker and Ball's Marocco, p. 14.0) are to this day possessed with a belief in the existence of such a plant. The Pr. Pm. translates it salgia sylvestris, wild sage; Palsgrave ache champeslie, field parsley; Cotgrave oke-ofCappadocia, or -of-Jerusalcm. The name is now assigned by botanists to a plant of the wormwood kind,

Ambrosia, I,.

That of the poets was diseovered by Isis :

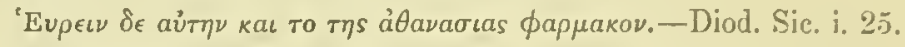

In Homer and the other early poets ambrosia was the ford, and ncetar the drink, of the Gods, as in Odyss. v. 93 :

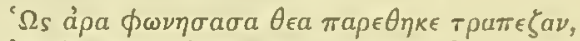

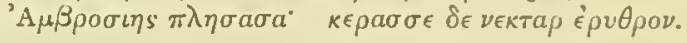

and in Orid (ex Ponto, i. 10)

"Nectar et ambrosiam, latices epulasque deorum."

But the two beeame eonfused together, and the same author tells us (Met. xiv. 606) that Venus, after bathing Eneas,

"Ambrosia cum dulci nectare mista,

Contigit os, fecitque deum."

In the beautiful tale of Cupid and Psyehe in the Golden Ass of Apuleius, (b. vi,) Jupiter in eonferring immortality on Psyche, gives her a cup of ambrosia to drink: "porrecto ambrosice poculo, Sume, inquit, Psyche, et immortalis esto." The Ambrose of our older English writers seems to have been Chenopodium Botrys, L.

Ameos, the genitive of Ammi, used, like Camy, for the seed of the plant,

A. majus, $\mathbf{L}$.

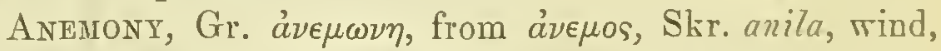
from an, to blow. It is said by Bion to have sprung from the tears that Venus wept over the body of Adonis, a myth that seems to whisper that the tears of that frail and loving goddess were soon blown away.-(Idyl. i. 1. 62). 


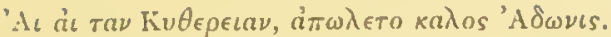

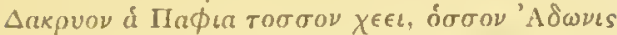

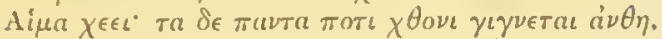

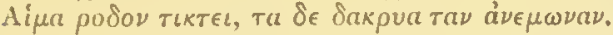

Alas the Paphian! fair Adonis slain !

Tears plenteous as his blood she pours amain.

But gentle flowers are born, and bloom around, From every drop that falls upon the ground:

Where streams his blood, there blushing springs the Rose, And where a tear has dropped, a Wind-flower blows.

Whether the flower that we now call Anemony, was that whieh the Sicilian writers meant, is a question, into which it were here out of place to enter. Pliny tells us (H.N. 1. xxi.c. 11) that it was so named, because it never opens but when the wind is blowing. Ovid describes it as a very fugacious flower, and after comparing it with that of the Pomegranate, says (Met.x. 737):

"Brevis est tamen usus in illis,

Namque male hrentem, et nimia levitate eadueum Excutiunt idem qui præstant nomina venti."

It is doubtful whether he meant the same plant as Pliny; and he could scarcely have meant that which we call so now; more probably a cistus, or rock-rose. The name is now applied to the grenus

ANET, dill seed, from L. anethum, Gr. àv $\theta 0 \nu$, Anemone, L.

A. graveolens, T.

Angelica, its Lat. name, either as Fuchs tells us, (Hist. Plant. p. 126,) "a suavissimo ejus radicis odorc, quem spirat," or "ab immensa contra venena facultate," from the sweet seent of its root, or its value as a remedy against poisons and the plague, yielding, as Brunschwygk tells us, "das aller-edelst wasser das man haben mag für die pestilenz;" and of which Du Bartas says, (Third day, p, 27,) Sylvestcr's translation, 1641,

"Contagious aire ingendring Pestilence

Infeets not those that in their mouths have ta'en

Angeliea, that happy counterbane 
Sent down from heav'n by sorne celestial scout, As well the name and nature both avovt."

Angelica sylvestrie, $\mathrm{I}$.

Anise, or as in "The Englishman's Doctor," Axisy,

"Some Anny seeds be sweet, and some more bitter."

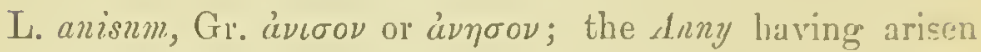
from a mistake of Anise for a plural noun;

Pimpinella -Inisum, L.

Anthovx, St. his nut and turnep, see under SAIæT A.

Apple, A.S. epl, appel, O.N. epli, Sw. reple, Da. aljle, G. apfel, O.H.G. aphol, Wel. afal, derived from a more aneient form, apalis, preserved in the Lith. obolys, or obelis. Lett. ahboli. In all the Celtie and Selavonian languages the word is, with allowanee for dialeet, the same. This similarity, or, we may say, identity of name, among alien nations would lead us to believe that it was brought with the tree from some one country, and that, no doubt, an Eastern one; and that the garden apple is not, as it is often supposed to be, merely an improved crab, but rather the erab a degenerate apple. This was, apparently, the only fruit with whieh our ancestors were aequainted, before they came into Europe; for, with the exception of a few wild berries and the hazel nut, it is the only one for whieh we have a name that is not derived from the Latin or French. It seems to have accompanied them on a northern route from the western spur of the Himalayan mountains, a district extending through Ancient Bactria, Northern Persia, and Asia Minor, to the Caneasus, and one from whieh we have obtained, throngh the Mediterranean eountries, and within the historical period, the peach, aprieot, plum, damson, eherry, filbert, vine, and walnut, and probably some of the eereal grains; a distriet in whiel there is reason to think that our portion of the limman race first attained to civilization, and whence it spread, with its domestie animals and plants, to the south-east and 
north-rest. The meaning of the word is unknown. It is very possibly from Skr. amb, eat, and $p$ 'hal, fruit, but as ap is, in Zend and Sanskrit, "water," we might be tempted to believe that it originally meant "water-fruit," or "juieefruit," with which the Latin pomum, from po, to drink, exaetly tallies. The rentarkable eoincidenees of name, to whieh allusion has been made, are due to the intimate eonnection with eaeh other of all the Ind-European nations and their languages, from their having grown up in the same nursery together in Upper Asia, and dispersed subsequently to their becoming aequainted with this fruit; and not to a mutual borrowing of it sinee their settlement in Europe.

Pyrus Malus, L.

Apricot, in Shakspenre (M.N.D. iii. 1) Apricock, in older writers, ABricot and ABREcocke, It. albericocca and albicocco, from Sp. albaricoque, Ar. al, burqüq or barkokon, from Mod. Gr. Врєккока, O. Gr. of Dioseorides and Galen, траєкоккц, L. precoqua or precocia, early, from the fruit having been considered to be an early peaeh. A passage from Pliny (Hist. Nat. xv. 12) explains its name. "Post autumnum matureseunt Persiea, rstate pracocia, intra xxx annos reperta." There is a good paper upon it in Notes and Queries, Nov. 23, 1850. "The progress of this word," says the author, "from W. to E., and then from E. to $\mathrm{S} . \mathrm{W}$., and thenee to $\mathrm{N}$., and its various ehanges in that progress, are strange. One would have supposed that the Arabs living near the region of whieh the fruit is a native, might have either had a name of their own for it, or at least have borrowed one from Armenia. But they have apparently adopted a slight variation of the Latin. The Spaniards must have had the fruit in Martial's time, [who alludes to it in the words:

"Vilia maternis fueramus precoqua ramis,

Nunc in adoptivis persica cara sumus.'

-Lib. xiii. Ep. 46.] 
but they do not take the name immediately from the Latin, but through the Arabie, and call it albaricogue. The Italians again copy the Spanish, not the Latin, and call it albicocco. The French from them have abricot. The English, though they take their word from the French, at first called it abricock (restoring the $/ 2$ ), and lastly with the French termination, apricot." Prunus armeniaca, L.

Arach, in Pr. Pm. and in Palsgrave Arage, the older spelling of Oraci.

Arehat, a lichen ealled more commonly Orchil,

Roecella tinctoria, DC.

Archanger, M. Lat. archangelica, so called, Parkinson tells us, "ab eximiis ejus viribus;" Nemnich, from its having heen revealed by an angel in a dream; more probably from its being in blossom on the Archangel St. Miehael's day, the 8th of May, old style, and thenee supposed to be a preservative against evil spirits and witchcraft, and particularly against the disease in cattle called elfshot, G. hexenschuss, ulcera regia. The name is applied to an nmbelliferons plant, Angelica arehangelica, L. and to certain labiates, severally distinguished as

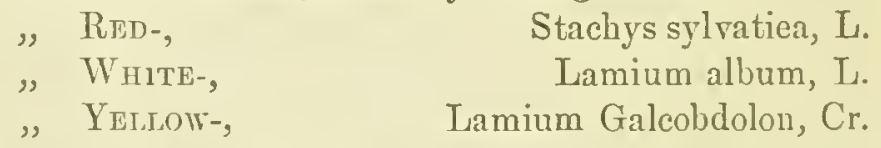

Annut, or Ennut, Du. aardnoot, the earth-nut, Carum Bulboeastanum, K. and Bunium flexuosum, With.

Arrow-Grass, a translation of its Greek name, triglochin, from the thrce points of its eapsules, $\tau \rho \in \iota \varsigma$, three, $\gamma \lambda \omega \chi \iota$, arrow-point, Triglochin palustre, L.

Arrow-head, from the shape of the leaves,

Sagittaria sagittifolia, L.

Arsmant, Fr. curage, i.e. cul-rage, the water-pepper, from the irritating effect of the leaves,

Polygonum Hydropiper, L.

Antichoкe, in 'Turnel Archinocke, It. articiocco, Sp. 
artichofa, a name whieh Diez derives from Ar. ardischantib, earth-thorn, and which was introdueed with the plant by the Moors of Spain.

Cynara Seolymus, T.

AsARABACCA, a name adopted, as a eompromise or middle term, in eonsequenee of the confusion between the two plants Asarum and Baccharis, one with the other. "In former times," says Parkinson (Th. Bot. p. 115), "divers did thinke that Asarum and Baeeharis in Dioseorides were all one hearbe, and thereupon eame the name of Asarabaecara; some taking Asa:um to be Baeeharis, and so contrarily some taking Baeeharis to be Asarum."

Inula Conyza, DC. and Asarum europæum, L.

Astr, A.S. resc, Da. and Siv. ask, O.N. askr, O.H.G, asc, G. and Du. esche. From the toughness of the rood it was much used for spear-shafts, and A.S. asc eame to mean a spear, and asc-plega, the game of spears, a battle. Fresne in the same manner was used in France for a spear, whenee the expression brandir le fresne. It was further extended to the man that bore it, and he was himself ealled asc. Being also the wood of whieh boats were built, the A.S. rese and O.N. askr meant a vessel, just as a barge with an oak bottom is ealled, from its rood, in L.Germ. eeke, Du. ceke, Sw. ela. The derivation and primary meaning of $A s h$ is obseure. It is not improbably connected with L. ascia, Gr. $\alpha \dot{\xi} \xi \nu \eta$, and axe, and with L. axis, an axle, from the tough wood of this tree having in all times been preferred for axe handles and axletrces.

Fraxinus exeelsior, L.

Mountain-, the rowan, from a faneied resemblanee of its pinnate leaves to those of the ash-tree, and its nsual plaee of growth,

Pyrus aueuparia, Gärt.

AsII-WEED, AISE- or Ax-WEed, from its ternate leaves somewhat resembling those of the ache or eelery. See ACHI: Agopodium Podagraria, L.

Asparagus, Gr. à trapayos,

A. offieinalis, L. 
Aspen, the adjectival form of $\Lambda$ spe, the older and more correct name of the trec, and that which is used loy Chances' and other carly writers; $\Lambda . S$. cepse and cesp, ri. aspe, O.H.G. aspa, O.N. espi, Populus tremula, L.

Aspuoner, Gr. $\dot{a} \sigma \phi o \delta \in \lambda \circ s$, a word of unknown derivation, applied in Homcr (Odyss. xi. 539) as an eppithet to a mcadow, év $a \sigma \phi \phi \delta \epsilon \lambda \omega \lambda \epsilon \iota \mu \omega \nu \iota$. Thic plant so called by Grcek writers of a later age, was one that had edible roots, that were laid in tombs to be food for the dead, and is that

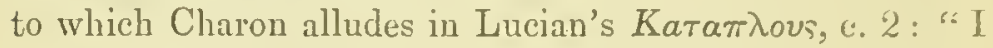
know, says he, "why Mcrcury kecps us waitiug so long. Down herc with us there is nothing to be lad but asphodel, and libations, and oblations; and that in the midst of mist and darkness; but up in heaven it is all bright and clear, and plenty of Ambrosia there, and nectar without stint." This root, under the name of cibo regio, food for a king, was highly csteemed in the middle ages, but howerer improved by cultivation, it is likely to have been troublesome by its diuretic qualities, and has probably for that reason gone out of fashion. There is some ground to suspect that it was the original claimant of an cxpressive name that has since passed to the dandelion.

The plant of the Greek poets is supposed to bc the

Narcissus pocticus L.

That of Lucian and of modcrn botanists, Asphodelus, L.

That of our earlier English and French poets, the daffodil, Narcissus Pseudonarcissus, L.

"Bog-, or LANCASHIRE-,

Narthecium ossifragum, Huds.

Scotch-, Tofieldia palustris, Huds.

Asses-FOoT: Fr. pas d'anne, the colt's foot, from the shape of the lcaf, Tussilago Farfarn, L.

Ass-PARsLey, in old works given as the translition of Fr. cicutaire, the same, probably, as fool's parslcy, Ethusa Cynapium, L. 
Aster, $\mathrm{Gr} . \dot{a} \sigma \tau \eta \rho$, a star, from the radiate flower,

Aster, L.

Autunn-Brils, from its bell-shaped flowers and their season of opening, Gentiana Pncumonanthe, I.

Avrass, in Pr. Pm. avence, in Topsell and Askham avance, M. Lat. avantia or avencia, in Ort. San. anancia, a word of obscure origin, and quite unintelligible, spelt also auartia, anantia, arancia, amancia, and enantica. As this plant was supposed to ward off the devil and evil spirits, venomous serpents, and wild beasts, it is probable that the Greek Évavtıa, in the sense of 'antidote,' may be the original and proper form of the word. Sce Herb BennetT.

$$
\begin{aligned}
& \text { „Common-, or Yellow-, Geum urbanum, L. } \\
& \text { " Mountarn-, Diyas octopetala, L. } \\
& \text { "Water-, or Nodding-, Geum rivale, L. }
\end{aligned}
$$

Averoyne, of the Stockholm Med. M.S., but long disused, $\mathrm{Fr}$. aurone, from Lat. abrotanum, the southernwood, Artemisia Abrotanum, L.

AwL-WorT, from its subulate leaves,

Subularia aquatica, L.

Aye-Green, cver-green, the houseleek, a translation of Lat. sempervivum. Aye is the A.S. crg, ever, properly an cgg, which, having no beginning or end, was symbolical of cternity. The plant was so called from its conspicuous tufts of evergreen leaves. Sempervivum tectorum, L.

Bacilelor's Buttons, a name given to several flowers "from their" similitude to the jagged cloathe buttons, antiently worne in this kingdom," according to Johnson's Gerarde, p. 4.72 , but ascribed by other writers to "a habit of country fellows to earry them in their pockets to divine their suecess with their sweethcarts ;"

usually understood to be a double varicty of Ranunculus, according to others, in some countics, of Lychnis sylvestris, L. Scabiosa succisa, L. 
BALdARE, the name that W. 'Turner gives in his Liluellus as that of the Florimer, one that possibly may allude to the god Balder and his restoration to life. See Auaraxtr.

Amarantus caudatus, $I$.

Bardmoney, or Bawd-Money, in Gower Barmesoryz, the mew, a corruption of L. valde lona, very grood. 'The Gretc Herball, ch. ccccxxiii, speaking of Sistra, says, "Sistra is dyll, some call it Mew, but that is not so. Howbeit they be very like in properties and vertue, and be put eche for other, but Sistra is of more vertue than Mew, and the leaves be lyke an herbe called valde bona, and beareth small sprigges as spiknarde. It groweth on hye liylles."

Meum athamanticum, L. in some authors, incorrectly, Gentiana lutea, L.

Batrock-GRass, A. S. bealloc-wyrt, from its tubers resembling small balls, whence its Greek name, o’ $\rho \chi \varsigma$,

Orehis, L.

Batir, BaUlir, or Bawn, contracted from Balsam, L. Galsanum, by some said to be derived from Hebr. bol smin, chief of oils, by W. Smith from Hebr. Lâsẩm, balm, and besem, a sweet smell, terms originally applied to a plant very different from that which now bears the name,

Mclissa officinalis, $\mathrm{I}$.
, Bastard-,
Melittis Melissophyllum, L.

Balsam, or Barsamixe, see above,

Impatiens Noli me tangere, I.

BANeberry, A.S. bana, murderous, from its poisonous quality. Hill says in his Herbal (p. 320), that children who have caten the fruit have died in convulsions.

\section{Actra spicata, L.}

BANETORT, from its being supposed, like several other marsh plants, to bane sheep, and Salmon tells us that it does so by ulccrating their entrails. Ranunculus Flammula, L.

BAnkcress, from its growing in hedge banks, the ledge mustard, Sisymbrium officinalc, L. 
Baxnot, the walnut, apparently a corruption of ball-nut, from the shape of its fruit, Juglans regia, L.

Barbara, St. her cress, see under $\mathrm{S}_{\text {T. }} \mathrm{B}$.

Barberiy or Berberny, M. Lat. berberis, Ar. barbāris,

B. vulgaris, $L$.

BARLEx, called in Wycliffe's Bible, Exod. ix, 31, barlich, in Sloane MS. No. 1571, 3, at fol. 113, barlych, and in the A.S. Chronicle, A.D. 1124, borlic. Verstegan says that "the name of barley was given to it by reason of the drinke therewith made called beere, and from beerlegh it came to berlegh, and from berlegh to barley." The dictionary derivation of it from the Welsh barlys is untenable, both for philological reasons, and for that it is highly improbable that the English of the twelfth century would have bort rowed from a half-eivilized mountain race a name for a familiar plant. See Bear. Hordeum vulgarc, L.

\section{Wall-. See Motse Batrley.}

Barmaby-thistle, from its flowering about the time of St. Barnabas' day, the llth of June old style, which corresponds to the 22nd June of the new.

Centaurea solstitialis, L.

Barrex-wort, called so, says Gerarde, p. 3s9, " because it is an encmy to conception, and not beeause it is described by Dioscorides as being barren both of flowers and leaves." Nevertheless, this belicf in its sterilizing powers may be due to the remark of Dioseorides, who must have meant some other plant; for this sceds very frecly in Styria and other parts of Austria.

Epimedium alpinum, L.

Base-Broon, L. Genista humilis, a name that docs not, as its Latin synonym would lead us to suppose, ref'er to its lowly growth as compared with that of the common broom, but to its being used as a buse to prepare woollen cloths for the reception of scarlet and other dyes.

Genista tinctoria, I. 
BasE-ROCKNT, a mignonette so ealled from its roclset-like leaves, and these wild mignonettes being used as a bare in dyeing woollen eloths. See Aubrey's Nat. IIist. of Wilt. (ed. Jaekson), p. 50.

Reseda lutea, I.

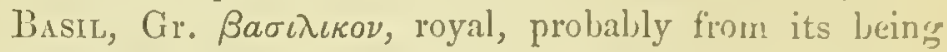
used in some royal unguent, bath, or medieine,

Oeymum basilicum, I.

"Field-, Calamintha Clinopodium, Benth.

Basil-thyme, so ealled, says Parkinson ('Th. Bot. p: 19), "beeause the smell thereof is so excellent, that it is fit for a king's house;" Calamintha Aeinos, Clair.

Bassiners, Fr. bassinet, a small basin, a skull-eap, snel as was worn nnder the helmet, from the shape of the flower,

Ranuneulus, $\mathrm{L}$.

"Brave-, in Lyte's Herball, Caltha palustris, L.

BAST-TREE, the lime-tree, from its inner bark furnishing bast for matting, a word introduced with the material from Germany or Denmark, and related to Skr, pas, bind, Pers. benden, and Zend and Skr. bandh, whenee Z. basta, bound,

Tilia europæa, L.

$\mathrm{BAY}, \mathrm{Fr}$. baie, formed, by the usual omission of $c$ between two vorrels, from L. baca, often so spelt for bacca, a berry. In old works bay means a berry generally, as " the bayes of ivyne," but as those of the sweet bay, the lauri bacce of Virgil, were an article of commeree, the term came to be applied to them exelusively, and was thenee extended to other evergreens, mueh as is laurel at the present day.

Laurus nobilis, L.

Daphne laureola, L.

BenN-tree, more properly White Bedu, from A.S. beam, a tree, O.S. bam, G. baum, Goth. bagms, O.N. bndmr, words related to G. banen, build. Beam, without the White prefixed, is a vague term, meaning in $\mathrm{A}$.S. a tree generally, so that Bean-tree is a silly pleonasm, a tree-trce.

Pyrus Aria, L. 
Bern, A.S. bean, O.N. baun, Du. boon, G. bohne, Da. bönne, Sw. böna.

Vicia l'aba, L.

Bear, Beer, or Bere, A.S. bar, Fris. bar, barley, a grain that inight scem to have been so callcd from leer, the liquor brewed from it, a word for which L. Diefenbach remarks that "sichere Etymologien fchlcn noch." Outzen and several other philologists support this derivation of it, but J. Grimm would trace it to Go. bairan, bear, whence baris, gen. barizis, O.N. barr, gen. bars. Gesch. d. Deutsch. Sprache, i. p. 65 . It may be related to Hind. bagra, a kind of millet (holeus spicatus, L.), that is much cultivated in the mountains of the north of India. In our northern counties bear means the four-rowed variety of barley and bigg the six-rowed. Brockett, p. 25. Hordeum vulgare, L.

Bearbirry or Bear's Bilberry, from its fruit being a favourite food of bears, Arctostaphylos uva ursi, Spr.

BEAR-BIND or BARE-BIND, from binding together the stalks of bear or barley, Convolvulus arvensis, L.

BEAR's-BREECH, from its roughness, a name transferred by some mistakc from the acanthus to the cow-parsnip,

Heracleum Sphondylium, L.

BEaR's-Ears, from its former Latin name, ursi auricula, in allusion to the shape of its leaf, Primula Auricula, L.

BEar's-root, from its digitate leaf,

$$
\text { Helleborus foetidus, } \mathbf{L} \text {. }
$$

Bear's-GarLick, so called, says Tabcrnæmontanus, "quia ursi eo delectantur,"

Allium ursinum, L.

BEArwont, from the G. bärwurz, which Adelung suggests is rather to be derived from its usc in nterine complaints than from the animal, Meum athamanticum, 'L.

BEDE-SEDGE, from its round bead-likc burs, resembling the beads used by Roman Catholics and Buddhists for counting their praycrs, A.S. beal, a prayer, a name given to it by 'Turner, Sparganium ramosum, L.

Beistraw, or Our Ladx's Bedstraw, L. Sher. Marice 
stramen, G. nnser lieben franen bellstro, from its saft, puffy, flocculent stems and golden flowers, a name that refer's to straw having formerly been used for bedding, even by ladies of rank, whence the expression of their being " in the straw." 'Thus in the Latin hymn, No. 128 in Bäsler's Altehristliche Lieder, Mary sings :

"Lectum stravi tibi soli, Dormi nate bellulc!

Stravi lectum fono molli: Dormi mi animule!

Ne quid desit, sternam rosis, Stcrnan foenum violis:

Pavimentum hyacinthis Et prasepe liliis."

The name may allude morc particularly to her having given birth to her son in a stable, with nothing but wild flowers for her bedding.

Galium verum, L.

"W HITE-,

G. Mollusgo, L.

"Yellow-,

G. verum, $\mathrm{L}$.

In old writers its Latin and German synonyms are giren equally to the wild thyme. See C. Bauhin de plantis sanctis, p. 71.

Bew-Lankspun, "from the resemblance of its petals studded with ycllow hairs to a bumble bee whose head is buried in the recesses of the flower." Treas. of Bot.

Delphinium grandiflorum, L.

"NETTLE, from its nettle-like leaves, and the supposed fondness of bees for its flowers,

Galeopsis Tetrahit, L.

, -ORCHIS or BEE-FLower, from the resemblance of its flower to a bee,

Ophrys apifera, L.

BEE's-NEST, from the nest-like compact growth of its infloresccnce,

Daucus Carota, L.

BeEch, A.S. boc, bece, beoce, Go. bolia, M.H.G. buoche, O.H.G. puocha, G. buch, Du. beuk, O.N. beyli, Da. büg, $\mathrm{Sw}$. bok, words which, in their several dialcets, mean, with difference of gender only, a book and a bceeh-trce, from Runic tablets, the books of our ancestors, having been made of this wood.

Figus sylratica, L. 
BEET, L. beta, from the resemblance of the seed to the sceond letter of the Greek alphabet. There are some verses of Columclla to this effect, which are quoted by luchs and Parkinson:

"Nomine cum Grajo, ceu litera proxima primæ Pangitur in cel"a docti mucrone magistri, Sic et humo pingui ferratie cuspidis ictu Deprimitur folio viridis, pede candida beta."

Nemnich pronounces this idea to be a mere grille or fancy, but gives no better derivation for the word.

B. maritima, L.

Beggar's Lice, from its burs sticking to the clothes, and somewhat resembling those vermin,

Galium Aparine, L.

BetL-FLower, from the shape of the corolla,

Campanula, L.

Belladonna, It. bella-donna, fair lady, the deadly nightshade, called so, according to 'Tournefort, and to G. Burnet (Outl. of Botany, 4514), and to Duchesne (Pl. ut. p. 90), from its berries, known in France as guines de cótes, beingr used by the Italian ladies as a cosmetic. Ray also says that it was called belladonna, "quia ex ejus succo sive aqua destillata fucum conficiunt fœminæ, quo faciem oblinunt, et ex rubicunda pallidam efficiunt frigoris vehementia." (Cat. Plant. Cant. p. 4.3.) Atropa Belladonna, L.

BetLeisle-Cless, from its occurrence at L'isle, a town of Burgundy, which has becn confused with Belleisle,

Barbarea præcox, RB.

Bex or White Ben, from a supposed Ar. behen, which however is not to be found, Silene inflata, $L$.

Bexxet, see Некв B.

BENT-GRASS, any wiry grass, such as usually grows upon a bent, i.e. a common, or other neglected broken ground, at word often used in that sense in old English poctry-as: "Bowmen bickered upon the bent." Chevy Chase, 
and preserved in Seotland to this day. The name of the grass seems to have been talien from its place of growth, as in the ease of healh, brake, and brier. Under the name of Bent, are eomprised Agrostis vulgaris, L. 'Triticum juneeum, L. Psamma arenaria, PB. and many more.

Berganот, a name popularly given to a eornmon garden plant from its odour,

Monarda fistulosa, $\mathrm{L}$.

Bertram, a eorruption of L. pyrelhrum, that scems to have been adopted from German writers,

P. Parthenium, L.

Berry Alder, a buekthorn that was onee wrongly associated with the alders, and distinguished from them by bearing berries, Rhamnus Frangula, L.

Berony or Wood Betony, L. betonica, said by Pliny to have been first ealled Vettonica from the Vettones, a people of Spain,

B. offieinalis, L.

Water-, from similarity of leaf to that of the wood betony, Serophularia aquatiea, $\mathrm{L}$.

Birolu, the tway-blade, L. bifolium, two-leaf, Listera ovata, RB.

BIG, O.N. bygg, a name of Seandinavian origin applied in our northern eounties and Seotland to the six-rowed variety of barley, and aeeording to Holmboe ( $\mathrm{v}$. bygg), unquestionably related to bua, dwell, whence byggia, till, as being the grain most eommonly eultivated in high latitudes,

Hordeum vulgare, $\mathrm{L}$.

BIGold, tinsel, false gold, applied to a weed that is not the genuine Golde, Chrysanthemum segetum, L.

Bilberry or Bulberry, Da. böllebär, a name which Outzen tells us, p. 24, means "dark-berry": "Die Heidelbeeren Bickbeeren heissen, d. i. seliwarzbeeren. Das engl. bill-berries, dän. böllebor, will eben dasselbe sagen."”

Vaeeinium Myrtillus, L.

BIND-WEED, a weed that binds,

Convolvulus arvensis, and sepium, $L$. 
" ВеACK-,

Bind-with, a with used to bind up faggots, the Traveller's joy,

Bırch, in the northern eounties Brrk, A.S. beorc, birce, or byrc, O.H.G. piricha, L.G. barke, Du. berke, Da. birk, Ic. and Sw. biörk, Russ. bereza, a $z$, as usual, replacing a German $k$, connceted with Skr. brichk, Hindi birchli, a tree, and perhaps with Skr. blurgga, a tree whose bark is used for writing upon. Klaproth argues from this word the northern origin of the dominant race in Hindostan, to whom this tree was the only one south of the Himalaya which they could name; all the others being new to them (Garnett, p. 33). It is the same word as bark in the two significations of tree-rind and vessel. In the first, as trecrind, we find it forming A.S. beorcan, to bark, L.G. bark, borke, Eng. Du. and Da. bark, Ic. and O.N. boerkr; in the sense of vessel, the Lat. barca, which, as it stands isolated in its own language, is, no doubt, of foreign origin, the source of Fr. barque, Du. and Da. barke, Ie. barkr, Eng. bark and barge. In the earlier period of our Germanic race, while it was still confined to the northern latitudes, birch bark was used, as at the present day in the same countries, for boat building and roofing, and probably, as in Norway occasionally, for greaves for the legs, and trom these different applications the tree took its name of barktree, a word connected with G. bergen, A.S. beorgan, protect, shelter, put into a place of safety. Betula alba, $\mathrm{L}$.

Bird's BrEaD, from the Fr. pain d'oiseau, the stoneerop, called so, apparently, from no better reason than its appearanec in blossom when young birds are hatehed,

Bird-cherry, a eherry only fit for birds, Sedum acre, L. Prunus padus, L.

BIRD'S-EYES, from its bright blue flowers,

Veroniea Chamæedrys, Is. 
and also, locally, "RED-,
Primula farinosa, $\mathrm{I}$. Geranium Rolscrtianum, $\mathrm{C}$. Bunds-Foot, from its incurved claw-like legumes, Ornithopus perpusillus, $\mathrm{L}$.

Bird's-Foot Trefoil, from its legumes spreading lite a erow's foot, Lotus corniculatus. I. and Trigonclla ornithopodioides, DC:

BIRD'S-NEsT, from its leafless stalks resembling a nest of sticks, such as crows make, Monotropa Hypopitys, L. also, from its matted roots, Neottia Nidus aris, L. and from the form of its inflorescence in fruiting, the wild carrot,

BIRD-SELD, canary grass used to feed birds, Daucus Carota, L.

Phalaris canariensis, $\mathrm{L}$.

Bird's-Tongue, L. lingua passerina, from the shape of the leaf, the knot-grass, Polygonum aviculare, L.

Binthwort, from its supposed remedial powers in parturition, suggested, on the doctrine of signatures, by the shape of the corolla, whenee also its Greek name from

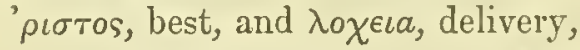

Aristolochia Clematitis, L.

Bishop's-LEaves, from being known in French as $l$ herle du siège, in reference to its remedial porvers in hemorrhoidal affections, and this word siège being understood as of a hishop's see,

Scrophularia aquatica, L.

BISHOP's-WEED, possibly from Fr. levesque, the name of another umbelliferous plant, transferred to this, and mistaken as meaning bishop, Ammi majus, L.

Bishop's-wort, a name applied, for reasons unknown, to the Devil-in-a-bush,

Nigella damascena, L.

Bistort, from its writhed roots, L. Gis, twice, torta, twisted, and thence called by Turner Twice-vorthen,

Polygoum Bistorta, L.

BitTer cRess,

Cardamine amara, L.

Bitter-sweet, L. Amara-dulcis, from the riud of its 
stalk, which, as Tumer observes (b. iii. 2), "when it is tirst tasted is bitter, and afterwards sweet," a quality from which it gets its German name, je lenger je lieler, the woody nightshade,

Solanum Dulcamara, L. (ed. 155 t, fol. 174) :

For all such time of love is lore,

And like unto the bittersuete,

For though it thinke a man fyrst suete,

He shall well felen ate laste,

That it is sower, and maie not laste.

BitTER VETCH,

Pyrus Malus, L. var.

Vicia Orobus, DC.

BitTER-Wort, from the taste of the root, a name adopted from the German bitterwurtz,

Gentiana, L.

BlackвеRry, from the black colour of its fruit in contrast with that of the raspberry and dewberry,

Rubus fruticosus, L.

Black-Bent, -Couch, or -Squitch, from its weedy character and dark purple flowers, the slender foxtail,

Alopecurus agrestis, L.

Black Bindweed, from its want of the conspicuous white flowers of the other bind-weeds,

Polygonum Convolvulus, L.

Black Bryony, from its dark-coloured glossy leaves, and black root,

Tamus communis, L.

Buack Horehound, from its dingy colour in contrast with the white-leaved true horehound, Ballota nigra, L.

Black Saltwort, in contrast with the Salsola,

Glaux maritima, L.

BLACK-SEED, the nonesuch, from its black head of legumes in contrast with the light yellow capitules of the hop-clover, Medicago lupulina, L.

BlackThons, the sloc, from the conspicuous blackness of its rind at the time of flowering, in contrast with that of the white-thorn,

Prunus spinosa, L. 
BI.ACK-Wonts, whortle-berrics, from their dark colour as compared with the cow- and cranlerry,

Vaccinium Myrtillus, L.

Buadder campion, from its inflated calyx,

Silenc inflata, $\mathrm{L}$.

BLADDER-FERN, from its bladder-like indusium,

Cystopteris fragilis, Bern.

BladDER HERB, the wiuter cherry, which, on the doctrine of signatures, was supposed, from its inflated calyx, to "cleanse the bladdcr, and open, scour, and purgc, the urinal passages,"

Physalis Alkekengi, L.

BLADDER-NUT, from its inflated seedpods,

Staphylea pinnata, L.

Bladder-snout, from the shape of the corolla, and

BLADDER-WORT, from the vesicles on its leaves,

Utricularia vulgaris, L.

Bleaberry, or Blafberry, from blae, a word that in our northern counties means "of a livid or pale-bluish colour," Atk. Clevel. Dial. Vaccinium uliginosum, L.

BLEEDING HEART, the name in the western counties of a dark variety of the wallflower, and apparently dating from a time when in its ordinary state it was called Heart's ease,

Cheiranthus Cheiri, L.

Blessed Thistue, a thistle so called, like other plants which bear the specific name of "blcssed," from its supposed power of counteracting the effect of poison,

Carduus benedictus, L.

Buind Netrle, from the resemblance of its leaves to those of a stinging nettle, and their not harming or sceming to notice any body; whence in most languages it bears a name that implies dead, dcaf, or blind;

Lamium album, L.

Buinks or Blinking-CHickweed, the "alsine flosculis conniventibus" of Merret's Pinax, so called from its half- 
elosed little white flowers peering from the axils of the upper leaves, as if afraid of the light, Montia fontana, I.

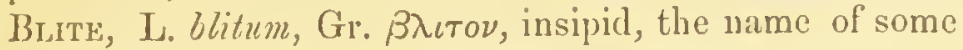
potherb whieh Evelyn in his Acetaria takes to be the Good Henry, and remarks of it that "Tis insipid enough,"

Chenopodium Bonus Henrieus, L. in more modern works usually referred to Blitum, Ls.

BroOD-ROOT, from the red eolour of its roots and its eonsequent adoption, upon the doetrine of signatures, for the cure of the bloody flux. "Tormentilla in dysenteria quod rubra est." Linn. in Bibl. Botan. p. 117.

Tormentilla offieinalis, L.

Blood-strange, from blood, and a verb only found in composition, strengen, draw tight, and metaphorieally, as in G. harn-strange, stop, Myosurus minimus, I.

BLOOD-WORT, or BLOODY-DOCK, from its red veins and stems,

Rumex sanguineus, L.

BLOODY WARRIOR, from its crimson-tinged petals, the dark-blossomed wallflower, Cheiranthus Cheiri, L.

Bloody-man's Finger, from its lurid purple spadix, Arum maculatum, Is.

BLow-BAI,I, the head of the dandelion in seed, from ehildren trying their luek ly blowing the pappus from its receptacle, Leontodon Taraxacum, L.

BLUE-BELL, from the bell shape and bright blue colnur of its flower, Scilla nutans, Sm. in Scotland, Campanula rotundifolia, L.

BLUb-BL,AW, a name that would at first sight seem to be merely "blue blow or blossom," but the latter word is in old works invariably spelt blaw, and is rather the G. blane, blue, Prov. blave, of which the lir. names of the flower, blaveole, blavelle, llavel, or blaverolle are the diminutives. Blue-blaw is therefore a tautology, and means "blue-bluc." Its Seotel name, llawort, is a better one.

Centaurea Cyanus, L 
Bude-3otrus, from the bottle shape of the involuere, and its brilliant blue flower,

Centaurea Cyanus, I.

BLUE-CAPS, from its tuft of blue flowers,

Seabiosa sueeisa, L. and Knautia arvensis, Coult.

Bog Asphodel,

Nartheeium ossifragum, Iud.

Bog-Bean, either a translation of Fr. trèfle des marais, or a fancied eorreetion of its proper name, luck-lyeain,

Menyantlies trifoliata, L.

BoG-BERRY, or BoG-WORT, the eranberry,

Vaecinium Oxyeoecos, L.

Bog Featherforl, from its finely divided feathery leares, or foils, the water violet,

Bog-Moss, Hottonia palustris, L. Spbagnum, L.

Bog Myrtle, or Dutch Myrtre, an evergreen aromatie shrub with some general resemblanee to a myrtle, and abundant in peat-mosses,

Bog-Rush, Myriea Gale, L.

BoG VIOLET, the butterrort, Pinguienla vulgaris, $L$. Botronac, from the Arabie, Lunaria biennis, $L$. Bout, a misspelling of Bout, Ranunculus, L. Boodle, see Buddue, Chrysanthemum segetum, L.

Borage, Fr. bourache, M. Lat, borago, probably a Latinized Oriental name brought with the plant from Syria, B. offieinalis, L.

Bore-cole, in Tusser Bore, according to Hettema, in Philol. Trans. 1858, from Du. boerekool, peasant eabbage, Brassica oleraeea, L. v. timbriata.

Bore- or Bour-tree, the clder, "from the grent pith in the younger branehes, whieh ehildren eommonly bore out to make pop-guns," Ray, N. C. Words, but perhaps the O.N. Gurr, barrr, or bör (Holmboe), Sambueus nigra, L.

BotTle-BRUSH, the field horsetail, from the form of its barren frond,

Equisetum arvense, L. 
Bouts, or Boots, the marsl marigold, from the Fr. bouton d:or, in respect of the yellow flower buds,

Caltha palustris, $\mathrm{L}$.

Bowyer's Mustard, supposed by Skinner to be so named from some apothecary, but more probably meaning originally "Boor's mustard," Du. boeren mostaert, written by Lyte, (clı. lxii.,) Bowers Mustard, and thence corrupted to Bowyer's, Thlaspi arvense, $\mathrm{L}$. and Lepidium rudcrale, $\mathrm{L}$.

Box, A.S. box and $b u x$, L. buxus, Gr. $\pi v \xi \circ s$, from $\pi v \xi \iota \varsigma$, a pyx or turned box made of wood,

Buxus sempervirens, L.

Box-HOLLY, from its box-like leaves terminating in a prickle like those of holly,

Ruscus aculentus, L.

Bor'S-LOVE, or LAD'S-LOVE, the southernwood, from an ointment made with its ashes being used by young men to promote the growth of a beard: "Cinis Abrotani barbam segnius tardiusque enascentem cum aliquo dictorum olcorum elicit." Matth. Comm. in Diose. iii., 25; a purpose for which it is also recommended by Herbarius, c. ii.

\section{Artemisia Abrotanum, L.}

Brakes, from Zrake, G. brache or brach-feld, uneultivated land, a term used to replace the M.Lat. fractitius or muptitius ager, land that is breakable, or again open to tillage after a term of years, land that is not prescrved as forest. The fern so called is named from its place of growth in the same way as whin, hcath, bent, and brier.

Ptcris aquilina, $\mathrm{L}$.

Bracken, supposed by Jamieson to mean female brake, but more likcly to be a word introduced from Scandinavia and identical with $\mathrm{Sw}$. bräken, which Rictz derives from Siv. Uräcka, brcak,

Pteris aquilina, $\mathrm{L}$.

Branible, A.S. Zremel, brembel, or brembel, in Pr. Pm. brymmeylle or brymbyll, Du. braam, G. Zrame, O.H.G. pramo, words, which, as Grimm remarks, signify prickly 
or thorny bushes, but are connceted ctymologically with G. Irrmmen, L. fiemere, and others indicating " noise." Bramble means usually the blackberry bush,

Rubus fruticosus, I.

but in Chaucer, (Tale of Sir Thopas, 1. 35),

"The bramble flour that bereth the red hepe,"

is the dog-rose,

Rosa canina, $\mathrm{L}$.

Brandy-3otTle, a name usually cxplained as alluding to the odour of the flower, but rather more probabily taken from the shape of the seed-vessel, the yellow water-lily, or can-dock, Nuphar luteum, L.

BraNk, buckwheat, from a Latin word, brance, that occurs in Pliny, (l. xviii. c. 7,) where it seems rather to mean a barley: "Galliæ quoque suum genus farris dedere, quod illic brance vocant, apud nos sandalam, nitidissimi grani." The word will be identical with blanc, white, Port. branco, and equivalent to wheat, which properly means "white." See Diefenbach, Orig. Europ. p. 265. Pol. pohanka. Polygonum Fagopyrum, L.

Breakstone, from L. saxifraga, a plant that fissures a rock, understood as meaning a lithontriptic plant to be administered in cases of calculus, a name applied to sereral diffcrent specics belonging to different genera, viz.

Pimpinella Saxifraga, L. Alchemilla arvenis, DC. and more particularly the genus Saxifraga, L.

Bride's Laces, see Lady's Laces.

Bridewont, from its resemblance to the white feathers worn by brides, Spiræa ulmaria, L.

Brier, A.S. Zrcer, Pr. Pm. and Gowcr, Brere, Fr. bruyere, called in Normandy bricre, from the waste land on which it usually grows, M.Lat. Urugaria or bruarium, W. Zrueg, a forest, Bret. Znig, from which brugaria would seem to have been formed, various wild specics of

Rubus and Rosa,

„, SWLET-, Rosa rubiginosa, L. 
Brier-rose, any wild rose, but chiefly the common hedge or dog-rose,

Brimstunewont, from its roots yiclding, as W. Coles says, "a ycllow sap which waxeth quickly hard, and dry, and smelleth not unlike to brimstone,"

\section{Pencedanum officinale, L.}

Bristle-fern, from the bristle that projects beyond its receptacle,

Trichomanes radicans, Sw.

Broccolt, the plural of It. broccolo, a small sprout, diminutive of brocco, a shoot,

Brassica oleracea, L. var. sabellica.

Brook-LIME, in old writcrs BROK-LEMPE or -LYMPE,

Veronica Beccabunga, L.

BrooK-WLed, from its growing beside brooks,

Samolus Valerandi, L.

Broosr, A.S. brom, G. brame, a word of the same origin as bramble, and O.N. brum, foliage, but at present applicd almost exclusively to a shrub of which besoms arc made, and called from it brooms,

\section{"DYer's-,}

Spartium scoparium, L.

Broon-RAPE, L. rapum geniste, from broom, a plant, upon which it is parasitie, and rape, L. rapa, a turnip, which its clubby tubcrous stem somewhat resembles,

Orobanche, L.

Brownwort, A.S. brunwyrt, G. braunwur\%, in Brunsfelsius and all the old herbalists spelt brnnnwurz, said to be called so from the brown colour of its stems and flowers, lut more probably from its growing so abundantly about the brunnen or public fountains of German towns and villages, Scrophularia aquatica and nodosa, L. also, from the brown colour of its flower spikes, and its being supposed to curc the disease called in German dic braunc, a kind of quinscy, the Brunclla, or, as it is now spclt with a $\mathrm{P}$,

Prunella vulgaris, L. 
Butsswort, from its supposed efficacy in bruises, the daisy, and also the soapwort,

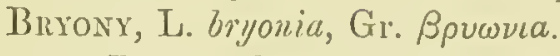

Betlis perennis, $I$.

Saponaria officinalis, I. "BLACK-, from its dark glossy leaves and black rort, Tamus communis, $\mathrm{I}$. of the root,

"Whrte-, from the paler eolour of the leaves and

Buckbean, believed by some botanists to have leen originally bog-bean, whieh, from its Freneh synonym, treffle des marais, is very plausible, but that in Dutch also it is ealled bocks-boonen, and in German bocksbolene, and eonsidered a remedy against the scharbock, or scurvy, whenee it is ealled scharlock's klee. Buckes-leane, and not bog-bean, is the name of it in all the old herbals, and this must be admitted to be the proper and established one, being, no doubt, derived from the Duteh word, one which seems to be a eorruption of L. scorlutus, the scurvy.

Menyanthes trifoliata, L.

" FringeD-, so called from its delieately fringed 'eorolla, and its allianee with the genuine buekbean,

Limnanthemum nymphæoides, Lk.

BuCK'S-BEARD, from its long eonrse pappus, rescmbling the beard of a he-goat, Tragopogon pratensis, L.

Buck's-HORNE, from its furcated leaves,

Plantago Coronopus, L.

Buckrans, from its offensive odour, see Rarson.

Allium ursinum, L.

in Parkinson's Th. Bot, and some otler Herbals, for buckrampe, in allusion to the spathe and spadix,

\section{Arum maeulatum, L.}

Buckthorn, from M. Lat. spina cerrina, or cerri spina of Valerius Cordus, who seems to have misunderstnod its German name $Z u x d o r n$, i.e. box-thom, a translation of the $\pi \nu \xi a \kappa a \nu \theta a$ of Dioseorides, to which this shrub and its eon- 
gencrs trere referred by the earlicr herbalists, for bockstorn, the thorn of a buck, Rhamnus eatharticus, L.

Buckinizat, Du. boekweit, G. buchuaitzen, a translation of $\mathrm{L}$. fago-pyrum, from the resemblance of its triangular seeds to beeehnuts, a name adopted with its culture from the Dutch,

Polygonum Fagopyrum, L.

Buddle, in Tusser spelt Boople, Du. Guidel, a purse, because it bears gools or goldins, gold coins, Du. gulden ; a punning allusion to its yellow flowers so called;

Chrysanthemum segetum, L.

Bug AGARIC, a mushroom that used to be smeared over bedsteads to destroy bugs,

Agaricus muscarius, L.

Bugle, M.L. bugula, dim. of abuga, one of the various spellings of a word given by Pliny as corresponding to Gr. $\chi a \mu a \iota \pi \iota \tau v s$, and variously written abiga, ajuga, iva, ctc.

Ajuga reptans, $\mathrm{L}$.

Bugloss, L. buglossa, from Gr. Bovs, an ox, and $\gamma \lambda \omega \sigma \sigma a$, tongue, deseriptive of the shape and rough surfaee of the leaves,

Anchusa officinalis, $\mathrm{L}$.

$\Rightarrow$ Field-,
$"$ Sea-,
$" \quad$ Vipelr's-,

Lycopsis arvensis, L. Mertensia maritima, Don. Echium vulgare, L.

Bugloss cowsire, the lung-wort, from its having the leaves of a bugloss and the flowers of a primula,

Pulmonaria offieinalis, $\mathrm{L}$.

Buliace, in the Grete Herball bolays, in Turner bulles, in Pr. Pm. bolas, the Sp. bolas, bullets, Lat. bullas, bosses on bridles, and ealled so from its hard round fruit,

Prunus eommunis, Huds, var. insititia, L.

Bullock's LuNGworT, from its eurative powers in the pueumonia of bullocks, suggested, on the doctrinc of signatures, by the resemblance of its leaf to a dewlap; see Mulueis.

Verbaseum 'T'liapsus, L.

Beili-Fist, M.L. bovisha, G. bofist, a word that has uc 
reference to bulls, but derives its first syllable from buffen, puff,

Lyeoperdon, L.

Bulis and Cows, more commonly called "Lords and Ladies," the purple and the pale spadices, respectively", of

Arum maculatum, L.

BUtL'S-Foot, from the shape of the leaf, the more commonly called coltsfoot, Tussilago Farfara, L.

BulL-WEED, from O.E. boll, any globular body, such as the seed-vessel of flax, Dan. boll, a ball, It. palla, Gr. $\pi a \lambda \lambda a$, the knapweed, so called from its globular involucre,

Centaurea nigra, $\mathrm{L}$.

BULL-WonT, properly pool-wort, from its growing in or near pools, Scrophularia, L. also, in Gerarde, for the same reason, Ammi majus, L.

Bulnusi, formerly spelt as in Lyte, ch. lii., pole-rush, the pool-rush, jonc d'eau, A.S. ea-risc, from its growing in pools of water, and not, like the other rushes, in mire,

Scirpus lacustris, L.

and incorrectly the reed mace, Typha latifolia, L.

BULL-SEGG, the pool-segg or -sedlge, the reed mace,

Typha latifolia, L.

Bumblekites, the blackberry, from Scot. kiyte, belly, as in the "Wife of Auchtermuchty":

"The deil cut aff thair hands, quoth he,

'That cramm'd your kytes sae strute yestreen!"

and bumble, applied in Chaucer, (Wife of Bathes T. 116 ) to the voice of the bittern; from the rumbling and bumbling eaused in the bellies of children who eat its fruit too greedily, Rubus fruticosus, $\mathrm{L}$.

BukDock, a name that, properly speaking, is a pleonasm; for bur and dock both meant originally, the one in French, and the other in the Germanic languages, a flock or lump of wool, flax, or hemp combed out in carding : but upon dock being extended from the bur-7ock to other broad-leaved plants, the first syllable was added, to distinguish this 
species (whieh pre-eminently deserved the name by the trouble it gave housewives) from plants of the sorrel and other tribes. The word bur is the $\mathrm{Fr}$. bourve, L. burra, and primarily means the lump or tangled mass of refuse fibre, of which the involuere of this species formed the nucleus. See Hardock. Aretium Lappa, L.

Bur Manigold, a eomposite flower allied to the marigold, with seeds that adhere to the clothes, like burs,

Bidens tripartita, L.

Bur parslex, from its bur-like bristly carpels,

Caucalis daucoides, L.

Bull kEED, from its narrow reed-like leaves, and the burs formed by its seed vessels,

Sparganium ramosum, L.

Búr tuIstLe, from its priekly involuere,

Carduus lanceolatus, L.

Bur-weed, or Burdock Clotweisd, a weed with large leaves and burs somewhat like those of the burdock or elotbur,

Xanthium strumarium, L.

BurNer, a term formerly applied to a brown eloth, Fr. brunette, It. Urunetta, dims. of brun and bruno, and given to the plant so called from its brown flowers,

\section{Poterium Sanguisorba, I.}

Burnet BLOOD-WORT, from its powel of stanehing blood, and its resemblanee to burnet,

Sanguisorba offieinalis, $\mathrm{L}$.

Burvet Saxifrage, from its supposed lithontriptic yualities, and the resemblanee of its leaves to burnet,

Pimpinella Saxifraga, L.

Burstwort, from its supposed efficaey in ruptures,

Herniaria glabra, L.

Bretcinfr's Broom, aecording to Loudon, and to the autlioress of "Sylvan Sketches," Miss Kent, from butchers making besoms of it to sweep their blocks; aceording to Parkinson (Th. Bot. p. 254), to sweep their stalls. But it 
seens to have been called so from leeing nsed to prescrve meat from rats and bats. Thus 'lrache, ed. ]5y5, p. 340: "welchen dorn etliche myacantham, d.i. murizum syinam nennen, darmmb das discr dorn der meusen nnol ratten zuwider ist." Matthioli (1. iv. c. 141), gives the same explanation of its Italian name, Pungi-toyi, prick-rats: "Nos, quod arcendis muribus is aptissimus sit, si salitis appensis carnibus funiculo circumligetur, Pungi-turi $1 \mathrm{He}$ trusca lingua dicimus." So also Castor Durante in his Herbario nuovo, p. 40\%: "Per avere i ranctti vencidi ed le foglie dure, et horride, se ne famno le scope e servono per cacciar, come si è detto, i topi e le nottole dalle carni salate." So also Lonicerus (Kraüterb., p. 204).

Ruscus aculeatus, $\mathrm{L}$.

Butcher's Prickwood, from skewers being made of it, Rhamnus Frangula, L.

ButTer aNd Egas, from the colour of the flowers,

Linaria vulgaris, $\mathrm{L}$.

Butterbur Coltsfoot, a plant so called perhaps from a confusion of Fr. bourre, whence bur in burdock, with Fr. benrre, butter. W. Turner in Libell. says: "Fœminæ hujus herbæ foliis butyrum involvunt, unde nomen fecerunt." Dr. How and W. Coles also derive the name from the leaves being used, as they suppose, for lapping butter in; a purpose to which they do not seem to be applied at the present day.

Petasites vulgaris, Dsf.

BuTTER-CUP, not from butter and cup, but from buttoneop, Fr. bouton d'or, the bachclor's button, a name giren to its double variety, the cup being the Old Eng. cop, a head, a word that became obsolete, and was replaced by cup. It will have meant button-head. Sec Goldcup and KIxGcup.

Ranunculus, L.

Butren-Dock, from its leaves being used for lapping butter, whence the Scotch name of it, Smair-dock,

Rumex obtusifolins, L. 
Butter-flower, Du. buter-bloem, G. schmalz-blume, from a mistaken notion that it gives butter a yellow colour; or, as Fuchs tells us, p. $87 \mathrm{~S}$, from the greasy surface of the petals,

Ranunculus, $\mathrm{L}$.

ButTER-JAgs, an obscure name, perhaps in the first place bulter'll eggs. According to the Rev. M. J. Berkelcy, the plant is popularly called Eggs and Bacon, and the name may refer to some resemblance borne by its flowers, which are yellow streaked with red, to sueh a dish.

Lotus corniculatus, L.

Buttenwort, from its greasy feel, "as if," says W. Coles, "melted butter had been poured over it,"

Pinguicula vulgaris, L.

Cabbage, Fr. caboche, It. cappuccio, from cabo, a head, being a variety of colewort that forms a round head,

Brassica capitata, L.

"St. Patrick's-, Saxifraga umbrosa, L.

"Sel-,

Crambe maritima, $\mathrm{L}$.

CaLanint, Gr. $\kappa a \lambda \eta$, good, and $\mu \iota \nu \theta \eta$, mint, as being a raluable antidote to the bite of serpents,

Calamintha officinalis, $\mathrm{L}$.

Calathian Violet, L. Viola calathiana, from L. cala-

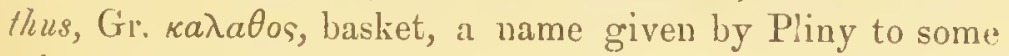
other very different plant, but by a mistake of Ruellius transferred to

Gentiana Pneumonanthe, L.

Cate, Cole, or Colewort, A.S. cawl, and cawlwyrt, Du. kool, L. canlis, a stalk, a name given to a thick-stemmed variety, the kohl-rabi, and extended to the other kinds of cabbage. "The Apothecarics and common Herbarists do call it cantis of the goodnesse of the stalke," says Gerarde, p. 249.

Brassica oleracea, L.

"SEA-,

Crambe maritima, L.

Caltrops, A.S. collrappe, in the romance of K. Alisander, 1.6070, calketrappen, MI.Lat. calcitrapa, from L. cal.r, 
a hecl, and M.Lat. trappa, a snare, a name first applied to the caltrop used in war to impe le the progress of curvalry, and thence to the spiny heads of this plant,

Centaurea Calcitrapa, L.

Calves-Hoot, Fl. calfsroet, Fr. pied de veau, from the shape of the leaf, Arum maculatum, L.

Cacves-snout, the snapdragon, Fr. mufle de veau, from a fancied resemblance in the seed vessel. "Antirrlinon," says Cordus, "fruetum fert vitulino capiti similem, tam cxquisita similitudine, ut etiam os et nares appareant." $\mathrm{Hc}$ illustrates his statement with a caricature of the seedvessel, which, as he gives it, eertainly bears a most extraordinary likeness to a calf's skull.

Antirhinum majus, L.

Calverkeys, in Awbrey's Wilts, probably the same as the Culverkeys of Walton's Angler, names no longer known.

CAmмоск, A.S. cammuc, -ec, or -oc, a name given by old writers to two very different plants, to one which was probably the Shepherd's Needle, but called by old writers Pencedanum, and to an Ononis. In the former sense it oecurs in Piel's Plowman's Vision, 1. 13,554:

"For communlike in contrees Cammoke and wedes

Foulen the fruyt in the feld, ther thei growen togideres."

In this sense it is found in several MSS. quoted by 0. Cockayne in Leechdoms, vol. ii., p. 374. The term kambuck is still given in Suffolk to the kcxes.

Seaudix Pecten, L.

harrow,

In the herbalists cammock means whin or rest-

CAmpion, from having been used in the chaplets with which champions at the publie games wore erowned. Ir. campione, M.Lat. campio, from campus, a battle-field.

BLADDER-, from its iuflated calyx,

Silene iuflata, $\mathrm{I}$. 
CAMPION, CoRN-, from its growing among eorn, Agrostemma Githago, L.

" Mesdow-, the Ragged Robin, Lyehnis flos eueuli, L.

„ Moss-, from its moss-like tufts,

Silene aeaulis, L.

" Rose-, from the eolour of the flower,

Lyehnis eoronaria, $\mathrm{L}$.

CaNary-grass, from being a grass of the Canary Islands, and used to feed Canary birds, Phalaris canariensis, L.
" RLED-,
Digraphis arundinaeea, Trin.

CAN-DOCK, from its broad leaves, and the shape of its seed-ressel, like that of a silver ean or flagon, Dan. aa-kande, the yellow water-lily, Nuphar luteum, Sm.

CANDLE-BERRY, from the fruit of an Ameriean species of the genus yielding wax of whieh candles are made,

\section{Myrica Gale, L.}

CANDLE-RUSII, from its pith being used for rush-lights, Juneus effusus, L.

Candy-tuft, or Candy-Mustard, a tufted flower brought from the Island of Candy, or Crete, Iberis umbellata, L.

Canker, a tree-fungus, from its seeming to eat like a caneer into a deeaying tree, Polyporus, Mieh.

CaNKER-Rose, from its red eolour and its detriment to arable land, the field poppy,

Papaver Rhœas, L.

Canterbury Bells, so named by Gerarde (Ed. em. p. 450), from growing very plentifully in the low woods about Canterbury, in allusion, probably, to the bells so ealled that were used by pilgrims on their road to and from the shine of St. Tliomas. Britten and Holland, p. 87.

Campanula Traehelium, L.

CaPER-Plant, or Wild CAPER, from its immature seed vessels being used in sauee for the buds of the real eaper, Euphorbia Lathyris, L.

Capildalre, the maiden-hair fern, from its being used 
to prevent the hair from filling off, says Matthioli (l. iv. c. 132), quoting from theophrastus: "al defluvium capillorum ntile," Adiantum Capillus Veneris, L.

Capon's Tall, Ger. em. p. 107s, from its spreading white llowers, some eultivated species of Valeriani, L.

Caprifoly, M.Lat. caprifolium, gont's leaf, a mistake for capparifolium, cuper-leat", the woodbine, which, in an Anglo-Sixon translation of Dioscorides quoted by O. Cockayne (vol. ii. p. 302), is spoten of as one "pe man cappluris and oprum naman wudubend hates", which is called capparis, and by another name voodline. The similarity of the leaf of this shrub to that of the cilper, and its habit of growing about walls and roeks, very nuturally led the northern nations to confuse then together, and the blundering mistake of cappari for capri has siven rise to the Fr. cherrefuille, G. geiss-blalt, etc. Loniceral Capritolium, L.

Carnoon, Fr. cardon, L. curlunculus, dim. of carlunes, a thistle,

Cynari Cirrlunculus, L.

Carline thistle, L. Carolina, so named after Charlemagne, Ciurl de gronte, of whom the legend relates, as we learn from Tabernæmontanus (vol. ii. p. 391), that " $\Lambda$ horrible pestilence broke out in his army, and earried oft many thousand men, which greatly troubled the pious emperor. Wherefore he prayed eamestly to God, and in his sleep there appeared to him an angel, who shot an arrow from a cross-bow, telling him to mark the plant upon which it fell, for that with that plant he might eure his army of the pestilence. And so it really happlened." The herb thus miraculously indieated was this thistle.

Carlina vulgaris, $\mathrm{L}$.

Carsation, incorretly derived in greneral from the flesh colour of the flowers, and supposed to be connected with C. came, but more correetly spelt by our older writers coronation, as representing the retonica coronariu of the enlly herbalists, and so called from its flowers being used in 
chaplets, corona. So Spenser, in his Shepherd's Calendir:

"Bring coronations and sops in wine

Worn of paramours."

Dianthus Caryopliyllns, $\mathrm{T}_{\text {. }}$.

Carpatron-grass, certain sedges, fram the resemblance of their leives to those of the carnation, more especially the Carex glauca, Scop., and C. panicea. C.

CARPEATER'S-mERb, from its corolla seen in profile being shaped like a bill-hook, and, on the doctrine of signatures, supposed to heal wounds from edged tools, the self-henl,

Prmella vulgaris, $L$.

Carraway, M.Lat. carui semina, sceds of eareum, Cir. kapoy, Carian, so called from its native country, Caria. This genitive case was alopted for the name of the seed, as in Arundel MS. 4\%, f. 55: "Carui growep mykel in merys in pe feld, and drye placys of grode crpe." Way's Pr. Pni. p. 333.

Carum enrui, L.

Carragern-moss, a sea-weed so called from an Irish word that means "a little rock," the name of some place in Ireland where it was first collected for sale,

Chondrus crispus, Lyngl).

C..nRot, Fr. carotie, L. carota, Dancus Carota, L.

Carse, an old spelling of cress, A.S. crers.

CASE-WEed, or CASSE-WEeD, so called in allusion to its little purse-like capsules, from Fr. caisse, L. capsa, a money-box, Du. cas,

Capsella Bursia pastoris, L.

Cassinosy, L. stachas sidonia, from Sidon, where the plant is indigenous,

Lavandula Stœehas, L.

Car's E.Ir, from the shape of its leaves,

Hypohæris maculata, L.

Cat's-Foot, from its soft flower-hcads,

Gnaphalinm dioicum, L. also, from the shape of its leaves, the gromul ivy,

Nepeta Glechoma, Benth. 
CAT's-MILK, from its millky juice oozing in drops, as milk from the smill teats of a cat, the sun spurge,

Euphorbia helioscopia, I.

CAT-3Int, or CAT-Nep, "beeause," say's Gerarde, p. 54:2, " eats are very much delighted herewith : for the smell of it is so pleasant unto them, that they rub themselves upon it, and wallow or tumble in it, and also feed on the branches very greedily;" the last a singular statement which the good old herbalist eopied from Dodoens (i. 4. 14), without aseertaining its truth.

Nepeta eataria, L.

Cat's-Tall, from its long eylindrieal furry spilies,

Typha latifolia, L. also from its eylindrieal spike, Phleum pratense, L.

CatCH-FLY, from its glutinous stalks, the genus Silene, and Lyehnis visearia, L.

CATCH-WEED, a weed that eatehes the passer by, Galium Aparine, L.

Caulflower, L. of Bauhin's Pinax, brassica cauliflora; of Parkinson, (Par., p. 505), caulis florida; from L. caulis, eole, and flores, flowers, formely ealled cole-flower, coleyflowers, and cole-flourey,

Brassiea oleraeea, L. var. Alorida.

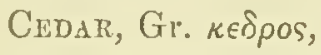
Pinu- Cedrus, L.

Celandine, Celinoine, or Celidoxy, L. chelidoninm, Gr.

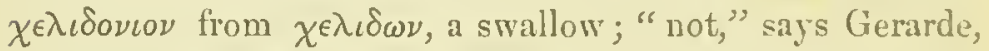
p. 911 , "because it first springeth at the eoming in of the swallowes, or dieth when they go away, for, as we have saide, it may be founde all the yeare, but beease some holde opinion, that with this herbe the dams restore sight. to their young ones, when their eies be put out;" a notion quoted from Dodoens (i. 2. 29), and eopied by him from Pliny (l. xxv. e. i.), and by Pliny from Aristotle. This wonderful faet is received and repeated by every botanical writer of those days, and is embodied by the author of the 
Schola Salernitana, 1. 217, and by Macer, c. 52, in the couplet :

"Cacatis pullis hac lumina mater hirundo, (Plinius ut scripsit) quamvis sint eruta, reddit."

William Coles, assuming the fact to be indisputable, thus moralizes upon it: "It is known to such as have skill of nature, what wonderful care she hath of the smallest creatures, giving to them a knowledge of medicine to help themselves, if haply diseases annoy them. The Swallow cureth her dim eyes with Celandme; the Wesell knoweth well the vertue of Herb Grace; the Dove the Verven; the Dogge dischargeth his marve with a lind of grasse; the Spider is triacle to the Monkey; the Hippopotamus dischargeth the aboundance of his bloud by opening a vaine; and too long it were to reckon up all the medicines which the beastes are known to use by nature's direction only."

Chelidonium majus, L.
" Lresser-, from its blossoming at the season when the swallow arrives, the pilewort, Ranunculus Ficaria, L.

Celeiry or Sellery, Fr. celeri, It. strlari, the plural of sellaro, the name under which it was introduced in the seventeenth century, corrupted from L. selinum, Gr. $\sigma \in \lambda \iota \nu \circ \nu$, Apium graveolens, $\mathrm{L}$.

Centaury, or Centory, L. centaurium, a plant so called, says Pliny, from the Centaur Chiron, who cured limself with it from a wound he had accidentally received from an arrow poisoned with the blood of the hydra. What plant this was, is uncertain. The name is now given to the knapweeds, which the Germans, resolving centaurinm into centum aureos, a hundred pounds, call Tausend Gulden.

Centaurea, L.

" Greater-, or More-, of the old black-letter herbals, a gentianeous plant. Askham, in his Lytel Herball, says of it: "It is named the More Centory or Larthgall: his 
floures be yelowe in the croppe;" and Dr. Linacre in his version of Macer, that "More Centory or liartligall hath leves lyke to the Lesse Centory, but more whyter, and yclowe flowers, and flowreth not but in the top."

Chlora perfoliata, L.

Lyte, and other herbalists since his time, incorrectly assign the name to the knapwced,

Centaurea nigra, L.

" Lessen-, so called in contrast with the greater- or more- centory,

Erythræa Centaurium, L.

Centinode, or Centronody, hundred knot, from its many joints, L. centum and nodus, Polygonum avieulare, L.

Ceterach, according to Du Cange from an Arabic word, C. officinarum, J. Sm.

Chadrock, see Chedlock.

Chafe-Weed according to Sir W. Hooker in Fl. Lnnd., from its use in Northumberland to prevent beavy loads from galling the backs of beasts of burden; but more probably from its application to chafings of the skin in the lumman subject, or, as Ray expresses it in Cat. Plant. Cant., "quoniam ad intertrigines valet;" the cud-weed,

Gnaphalium germanicum, $\mathbb{T}$.

ChafF-WeEd, from its small chaffy leaves,

Centunculus minimus, L.

Chalots, sec Shallo't.

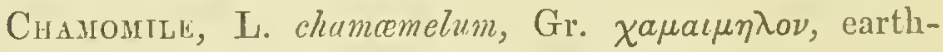
apple, from the odour of its flowers,

Anthemis nobilis, L. Matricaria chamomilla, L.

Champignon, from the French through M.Lat. campinio from campus, a ficld,

Marasmius orcades, Fries.

Chantarlele, from the French, M.Lat. canthurellus,

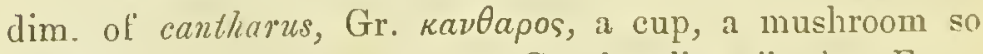
called, Cantharellus cibarius, Fr.

Chartock, Carlock, or Carlock, in Scotland SkelLoch, A.S. cerlice, which seems to be formed from leac, a 
plant, and cerran, turn, and to indicate a viearious plant, a weed of fullow ground. The name is at present given to a wild mustard.

Brassiea Sinapistrum, Boiss.

Checkered LiLy, from the markings on the petals, Fritillaria Meleagris, L.

Cheddar Pink, from its place of growth in Somersetshire, on the eliffs of that pieturesque ravine,

Dianthus cresius, $\mathbf{L}$.

Chedlock, Chadlock, or Kedlock, A.S. cerleleac, from leac, a plant, and cede, whieh seems to be the same as L.Gcrm. kiülick, kettich, köddick, Da. kidike, related, perhaps, to Da. licle, annoy. In the eastern counties chad means the refuse sifted from wheat. The name is now eonfounded with charlock, but in Westmaeott's Seripture Herbal, p. 86 , and other old works, is assigned to the hemlocks. 'There is nothing related of St. Chad or Cedde, that in any way eonnects him with these weeds.

Brassiea Sinapistrum, Boiss.

Cheesebouls, the poppy, from the shape of the ripe capsule resembling that of round cheeses,

Papaver somniferum and P. Rhœas, $\mathrm{L}$.

Chefse-Rennet, or -Running, a name given to the yellow lindy's bedstraw from its suppcsed power of eurdling milk. "Galium inde nomen sortitum est suum, quiod lae eongulet." Matth. 1. iv. e. 91. A.S. cys-gerun, from cys, eheese, and gerun, a word eonnected with G. rinnen and gerinnen, Sw. rönna, eongulate.

Galium verum, L.

Creet, the name of a spurious oil that in Gerarde's time was palmed off upon the publie for the Spanish oil of Sesamum. See belorv, Gold of Preasure.

CHEIr, WrLd-, the wallflower, from its Isatin name,

Cheiranthus Cheiri, I.

Cuequer-Tree, the serviee-tree, so called in Evclyn's Sylva, and in Sussex at the present day, from Choker, the 
choke-pear, being an antique pronunciation of tlie word which we find in the humorous old ballad of 'The Frere and the Boy, 1. 115 :

"Whan my fader gyveth me mete, she wolde thereon that I were chcke." i.e. choaked.

See ChoKe-pear.

Sorbus domestica, L.

Cherry, from O.E. Cherise, as it is spelt in Chaucer, a word that was mistaken for a plural of cherry, Fr. cerise,

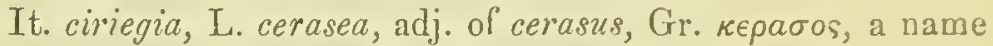
brought with the tree from Asia Minor,

Prunus Cerasus, L.

"BIRD's, a sort fit for birds only,

Prunus Fadus, L.

WILD-, or Gean,

Prunus avium, $\mathrm{L}$.

Cherry-Trood, in Jacob's Pl. Faversh, the water-elder, from its bright red fruit, Viburnum Opulus, L.

Chervil, A.S. carfille, Fr. cerfeuil, L. charophlyllum, Gr. $\chi a \iota \rho \epsilon \phi v \lambda \lambda o \nu$, from $\chi a \iota p \omega$, rcjoice, and $\phi v \lambda \lambda o \nu$, leaf, Chærophyllum sylvestre, $L$. " Hemlock-, or Rovgr-, Caucalis Anthriscus, L.

Chesses, a name that by some mistalie has been transfcrred to this plant, the peony, from the poppy, which, from the shape of its capsule, was called chasses and chese-bunles, Pæonia corallina, L.

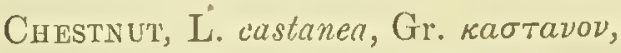

Custanca resca, Lam.

"Horse-, probably so named from its coarseness, but accordirg to Purkinson (Th. Bot., p. 1402), from being used in Turkey as a food for horses suffering from shortness of wind,

Esculus Hippocastanum, L.

Churisaunce, in Spenser's Sheph, Cal. April, 1. 14: :

"The pretty pawnee and the chevisaunce,"

cvidently a misprint for cherisaunce, comfort, heart's-ease, the cheiri or wallilower, the plant to which the name of 
Ileart's-ease was originally given. The word is omitted in the glossarics to Spenser, but oeeurs in Chaneer's Romaunt of the Rose, 1. 3337 :

"Then dismayed I left all soole, Forwearie, forwandred as a foole, For I ne knew ne cherisaunce."

Cheiri is the Moorish name Keiri, with whieh the plant now so familiar to us was brought hither from Spain.

Cheiranthus Cheiri, I.

Chrck-pes, or Chiches, It. cece, L. cicer,

$$
\text { C. arietinum, } \mathrm{L} \text {. }
$$

Chickling, a spurious Chick; cf. Vetehling and Crambling;

Lathyrus, L.

CHickтLed, A.S. cicena-mete, from the various plants comprehended under this name having been used to feed chickens. "Qui alunt avieulas eaveis inelusas hoe solent illas, si quando cibos fastigiant, recreare." W. Turner, Libell. "It is thought to be wholesome for siek birds, whenee ealled Chickweed." Threlkeld. "On en eonsomme beaucoup pour la nourriture des oisenux de volière." Duehesne, s. 1. plantes utiles, p. 226.

Stellaria media, L. also, in Hudson, Veroniea arvensis, and agrestis, L. Mouse-ear-, Cerastium vulgatum, Huds. Winter-grene-, Trientalis europæa, $\mathrm{L}$.

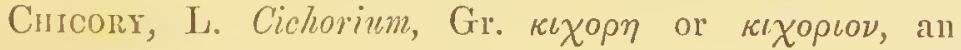
ligyptian word. "Intybum in Egypto Ciehorium voeant." Plin. N.H. 1. xx. c. 8 .

C. Intybus, L.

Cirier, Wild-, see Chrvisaunce, the wallHower, from an Arabic word, Keiri, Cheiranthus Chciri, L.

Childing Crowelid, a parturient eurlweed, Gnaphalium germanieum, W.

Cinforng Pink, a parturient pink, one that is ealled so from its throwing out younger and smaller flowers like a family of little children round it. Chilling is an expression 
analogous to "calving," "kittening," cte., ayd occurs fiequently in old authors. 'Thus in Lev. xii. 3, Wycliffe"s: version lias, "If a woman childip a male clisld :" arsd in Gen. iv. 1, 2, "Eve childide Cain, and eft sche chilntile lis brother Abel."

Dianthus prolifer, J.

Chrves, in R. Turner's Bot. p. 175, Cives, Fr. cives, derived by Diez from L. cepa,

Allium Sehcenoprasum, L.

Choke-Pear, Fr. poire d'estrangrillon, L. pyrum strangulatorium, Ger. p. 1270, a name given to a wild pear so hard and austere as to ehoke; with an allusion perhaps, to the death of Drusus, a son of the Emperor Claudius, which was eaused by a fruit of this eharaeter;

Pyrus eommunis, $\mathrm{L}$.

( hlistopher, see Herb Christopher, a name given to several different plants for reasons unkiown.

Christmas, from being used for deeoration at that season, the bolly, Ilex Aquifolium, $\mathrm{L}$.

Chuistuas Rose, from its open rose-like flower, and its blossoming during the winter months,

Helleborus niger, $\mathrm{L}$.

Christ's LAdDER, an old name, for we find it as Christis leddere in eatalogues of the fourteenth century. From the plant having been ealled fel-wort, earth-gall, fel-terra, ete., we may suspeet that it has arisen from Christis galle, Christ's gall, or Christis schale, Christ's Cup, having been mistaken for Christi scala, Christ's ladder, and that it alludes to the bitter draught offered to Jesus upon the eross.

Erythroa Centaurium, L.

Churd,'s head, from its rough hairy involuere,

Centamrea nigra, $\mathrm{L}$.

Churl's Treacle, garliek, from its being regarded as a Triacle or antidote to the bite of venomons animals. Sce Poor MaN's 'Treacle.

Allinm sativum, L. 
Chursstaff, from its straight stem spreading into a flat top, the sun-spurge,

Euphorbia helioseopia, L.

Crвbols, Fr. ciboule, It. cipolla, seallions, L. capnlla, Allium Asealonieum, L.

Cicely, Gr. $\sigma \epsilon \sigma \epsilon \lambda \iota$, some umbelliferous plant. "Rovgr-, Cauealis Anthriseus, Huds. "SwEeT-, from its agreeable odour,

Myrrhis orlorata, L.

WILD-,

Cideragh, Fr. cillrage, Chærophyllum sylvestre, L. Polygonum Hydropiper, L.

Crnquerorl, in A. Askham's Lytel IIerball Quynckefolye, Fr. cinq and feuilles, L. cinque foliola, so ealled from its five leaflets,

Marsh-;

Ciss, abbreviated from Cicely.

Chappedepouch, a nickname that alludes to the lieensed begrging of lepers, who stood at the cross-ways with a bell and a elapper. Hoffmann von Fallersleben in his Niederländiselıe Volkslieder says of them, p. 97: "Separated from all the world, without house or home, the lepers were obliged to dwell in a solitary wretehed hut by the road-side; their clothing so seanty that they often lind nothing to wear but a hat, and a eloak, and a begging wallet. They would eall the attention of the passers-by with a bell or a elapper, and receive their alms in a eup or a bason at the end of a long pole. The bell was usually of brass. The clapper is deseribed as an instrument made of two ol three boards, by rattling whieh they exeited people to relieve them." The leper's would get the name of lattle-ponehes, and this be extended to the plant in allusion to the little purses which it hangs out by the way-side.

Capsella Bursa pastoris, L.

Crary, in W. 'Turner's Libellus Clake, M.Lat. sclarea, a word formed from clarus, clear, by prefixing the preposition ex, whenee It. schiarire and schiarare. 'I'his word 
Clary affords a eurious instance of medicil research. It was solved by the apotheearies into clear-cye, franslated Oculus Christi, Godes-cie, and Sce-brighl, and eye-calses made of it. See Gerarde, p. 627. Salvia Sclarea, L. WIr,D-, Salvia Verlenaca, $\mathrm{L}$.

Claver, Du. klaver, the old and correct way of spelling Clover. See Clover.

Cleavers, or Clivers, the goosegrass, A.S. clife, Du. kleef-kruid, from its eleaving to the clothes, and O.F. clivers, claws, as in the Owl and the Nightingale, 1. 1.5.5:

"Thu havest clivers suthe stronge."

Galium Aparine, L.

Ciematis, Gr. $\kappa \lambda \eta \mu a \tau \iota s$, a word adopted from Dioseorides, but which in his writings and in Pliny's was applied to plants different from those to whieh it is now given, the Lady's bower, and its allies,

\section{Cliders, see Clite.}

Clematis Vitalba, L.

Clifw pink, from its growing upon Cheddar Cliffs in Somersetshire,

Dianthus ersius, L.

Clite, Clithe, Cliders, and Cutheren, a name of the goose-grass, probably from Cliver, by a change, not unfrequent, of $v$ to th; see Cleavers. Galium Aparine, L.

Clmibers, from its habit of climbering, or attrehing itself to objects, the Fr. grimper, originally identical with griper, elutch, a use of the word found in Tusser, p. 109 :

"Set plenty of boughs among runcival pease, "To climber thereon, and to branch at their easc."

the Virgin's bower, Clematis Titalba, Is.

CLOG-TEED, a shortened form of keyc-logge, as it is spelt in Turner of Tottenham, quoted by Way in a note to Pr. Pin. p. 27S, a word formed of licek, a hollow stalk, ancl lock, A.S. leae, a plant, and signifying the kex-plant, the eow-parsnip,

Heraeleum sphondylium, I. 
Close Sclences, the Dame's Violet, called, as Parlininson tells us (Th. Bot. p. 62S), the single variety of it, Single Sciney, and the double variety, Close Sciney, from which Gerarde made this ridiculous name. Sciney, no doubt, has arisen from its specific name, Damascena, understood as Dame's Scena.

Hesperis matronalis, L.

Clot-Bur, the bur-doek, called in Chaucer and in $\mathrm{Pr}$. Pm. Clote, sometimes spelt incorrectly Clod-Bur, A.S. clate, G. Kilette, a bur that sticks to clothes, a word connected with many others beginning with $c l$ or $k l$, such as cleare, climb, cling, liletten. The name may possibly have some connection with clout, through a confusion between the Latin name of the plant, lappa, and Du. lap, G. lappcn, a clout, whence our English verb lap; as in Pierce Plowman's Crede, 1. 438:

"Thereon lay a litel chylde lapped in cloutes."

Aretium Lappa, L.

CLOCD-BERRY, from its growing on the cloudy tops of mountains, Ger. p. 1368, Rubus Chamæmorus, L.

Clove Gilliflower, from its scent of clove, Sp. clavo, a nail, the shape of the spice so called,

Dianthus Caryophyllus, L.

Clover, or, as it is more correctly spelt in all the herbals, and all our older writers, and in Lowland Scotch, Claver, Du. klaver, A.S. clefer and cleefra, Da. klever. It is evidently a noun in the plural number, probably a Frisian word, and means "clubs," from L. clava, and refers to the clace trinodis of Herenles. It is in fact the club of our cards, Fr. trèfle, which is so named from its resemblance in ontline to a leaf with thrce leallets. Trifolium, L.

"Alsike-, Trif. hybridum, L.

" Birdsroot-, from its elaw-like legumes,

Lotus corniculatus, L.

and Trigonella ornithopodioides, DC.

Crimson-,

Trif. incarnatum, L. 


Dutci-,
" Harlisfoot-,
" Harts-,
" HearT-,
Hop-, Torif. a

" Meadow-,
" Plaister-,
" Red-, or Purple-,
Strawterry-,

Trif. repens, IJ. I'rif: arvense, I. Mclilotus officinalis, I. Medicago maculata, L. , the lucerne,

Medicago satira, L. Trif. pratense, L. Mclilotus officinalis, L. 'Trif. pratense, $\mathrm{I}$. Trif. fragiferum, L.

Clown's Allheal or Woundwort, so called by Gerarde, p. 852 , because a countryman, who had cut himself to the bone with a scythe, healed the wound with it in seven days,

Stachys palustris, L.

Clown's LUNG-Wort, from its use in pulmonary disease, Lathræa Squamaria, L.

Club-yoss, a mossy plant with a club-like inflorescence, Lycopodium, L.

Club-Rush, from its club-like inflorescence, the reedmace, Typha latifolia, L.

Con-NuT, from cob, a thick lump, O.E. cop, head, so called from being used in a game called cols-nut,

Corylus Avellana, L. var. grandis.

Cuck's comb, of botanists, from the shape of the calyx, Rinanthus Crista galli, L.

Cock's conrs, of Hill's, and somc other herbals, from the shape of its lcgume, the sainfoin, Onobrychis sativa, $L$.

Cock's сомв of the gardeners, Celosia cristata, L.

Cock's-COmb-Grass, from the shape of the panicle, Cynosurus cchinatus, $\mathrm{L}$.

Cock's-Foot, from the shape of the spike,

Dactylis glomerata, L.

Cock's-IIEAD, from the shape of the legume, the sainfoin, Onobrychis sativa, $L$. 
Cocks, from children fighting the flower-stems one against the other. See Kенps. Plantago lanceolata, L.

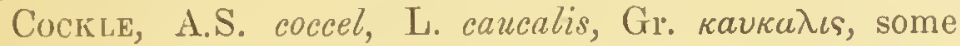
umbelliferous plant, which Clusius says (p. ceii.) was the

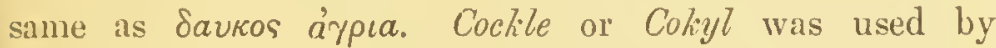
Wycliffe and other old writers in the sense of a weed generally, but in later works has bcen appropriated to the gith, or corn pink,

Agrostemma Githago, L.

ConLrn, originally coddling, from coddlle, to stew or boil lightly, a boiling apple, an apple for coddling or boiling, a term used in Shakspeare (Tw. N. i. 5), of an immature apple, such as would require cooking to be eaten, but now applied to a particular variety, Pyrus Malus, L. var.

Codlins and Creas, from the odour of its flowers, or of its fresh shoots, or according to Threlkeld, of its bruised leaves, the larger willow-herb so named after a once fivourite dish alluded to in King's Cookery :

"In cream and codlings rev'ling with delight."

Epilobium hirsutum, L.

Col, abbreviated by the Apothecaries from Coliander once used for Coriander,

Coriandrum sativum, L.

Coleseed, or Coldard ; see Calee; rape,

Brassica Napus, L.

Coleirort, or COLJET, cabbage, Brassica oleracea, L.

Colmenier, a name given in the Herbals to the Sweet William, and also spelt Tolmeiner, which in Parkinson is divided into I'oll-me-neer, as though the meaning had been Cull me, or Toll me near, probably a fanciful explanation of a name derived from some unknown foreign word, d'Allemagne, perhaps; see Tolmeiner.

Dianthus barbatus, L.

Colt's Foot, L. ungula caballina, from the shape of the leaf, 'T'ussilago Purfima, L.

Coltza, f'lem, kool-zaad, cole-seed,

Brassica Napus, L. 
Columbins, T. colnmbina, adj. of columba, pigeon, from the resemblanee of its neetaries to the heads of pigeons in a ring round a dish, a favourite deviee of ancient artists, Aquilegia vulgaris, I.

Courrey, L. comfirma, from its supposed strengrthening qualities, see KNıт-Back, Symphytum officinale, L.

"Spotted-, see Lungwort.

Consound, or Consoud, L. consolida, "quia tanta pros. tantia est, ut earnes, dum eoquuntur, eonglutinet addita, unde nomen :" Pliny, xxvii. 6. A name given in the middle ages to several different plants, and among them to the daisy,

Bellis perennis, L.

to the comfrey,

to the bugle,

and to the wild larkspur, Symphytum offieinale, L. Ajuga reptans, L.

Conval Lily, L. lilium convallium, Gr. крunov $\tau \omega \nu$ $\kappa o r \lambda a \delta \omega \nu$, lily of combes, ineorreetly translated "Lily" of the valley." The expression is used in the Vulgate translation of the Bible (Cant. ii. 1), and is appropriately given to this plant, as the flower of hollows surrounded by hills, its usual place of growth, although certainly not the flower meant by the royal poet. Convallaria majalis, $\mathrm{L}$.

Convolvulus, an adopted Latin name from L. convolvere, to roll round, the bindweed,

C. arvensis, and sepium, $L$.

Cop-rose, from its red rose-like flower and the eop-or button-like shape of its eapsule, Papaver Rhoas, L.

Coral-root, from its branehing and jointed root-stoek resembling white eoral, Corallorhiza innata, $\mathrm{RB}$.

CORAL-WORT, from its white root, and the "divers small round knobs thereon resembling the knaggy eminenees of eoral," W. Coles, p. 56, Dentaria bulbifera, L.

Cond-Grass, ealled so by Turner, beenuse he "saw that rishe in the islands of Last Friesland, and the people there 
make ropes of that rishe, and thache thcir houses also wyth the same,"

Spartina stricta, Sm.

Cormander, a plant, says Cogan, p. 26, "commonly

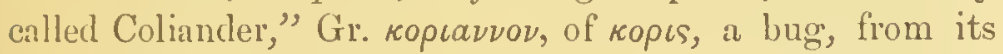
odour,

Coriandrum sativum, L.

Conk, the orehil, Norw. korkje, a corruption of orchil, whieh see,

Roccella tinctoria, DC.

" in the Highlands, Lecanora tartarea, Ach.

Conme, the service-tree, from an ancient Gaulish name

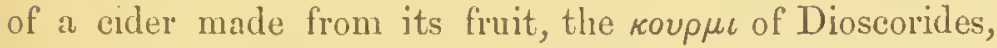
whence Fr. cormier, see Service Tree,

Pyrus domestiea, Sm.

Cormeille, Corr, or Caryylie, Gael. caermeal, the heath-pea, a word adopted from the Gaelic,

Orobus tuberosus, L.

Cons, one of several words, which being common to widely separated branches of the Ind-European rnee, prove the praetiee of tillage among our aneestors before they left their first home in eentral Asia, Skr. Karana, Go. kaum, L. granum, Russ. zerno, a term applied to. the several kinds of grain most commonly used in their respective countries. Max Müller refers the word to Skr. Kurna, ground.

Cory-bind, see Bind-weed and Bear-bind.

Corn-hottle, sce Blue Bottle.

Corn-Cockine, see Cockle.

CORN-Flower, from its being one of the gayest and most conspienous wild flowers of corn-fields, Du. korenbloem, Isatin in Ort. San. Flores frumentorum, Fr. fleur de blé, the bluc-bottle,

Centaurea Cyanus, $\mathrm{L}$.

Conx-Honewort, from its use in euring the hone, or boil on the cherk, Pctroselinum segctum, L.

Corn-Marigold, a golde, the pest of corn-fields in the south of Europe,

Chrysanthemum segetum, $\mathrm{L}$. 
Cons-Prnk, in Northamptonshirc (Baker), the corncockle, in some counties, Agrostemma (jithago, I.

Conn-Poppy, or -Rose,

Corr-Salad,

ConN-Violet, Campanula hybrida, I. Papaver Rhosas, $\mathrm{L}$. Valcrianella olitoria, L. Campanula liylorida, L.

Cornel, It. corniolo, L. corneolus, dim. of corneus, adj. of L. cormus, Gr. крауєıа,

Cornus sanguinea, $I$.

Cornish Moneywort, from its round leaves, and its having been first discovered in Cornwall, and supposed peculiar to that county, Sibthorpia curnpa, L.

Coronation, the older and more corrcet spelling of carnation, from its M.Lat. name Vettonica coronaria, as in Dodoens (P. ii. l. i. c. 18), Tabern. (vol.ii.c. 1), and Lyte (b. ii. cl. vii.), who, in speaking of Clove Gillofers, says, "The greatest and bravest sort of them are called coronations or cornations." See Carration. Dianthus Caryophyllus, L.

Costmary, L. costus amarus, its name in Banhin's Th. Bot. p. 674, Fr. coste amere, misunderstood as Costus Murice, from Gr. кобтos, some aromatic plant unknomn, an crror that has very naturally arisen from this one liaving becn dedicated to St. Mary Magdalene, and called after her, Maudlin, cither in allusion to her box of scented ointment, or to its use in the uterine affections over which she presided. In old authors it occurs as Herba sancte or dina Mrarice. See Maudlin. Balsamita vulgaris, $W$.

Cotton-grass, or -Rush, a grass-like plant with secdspikes rescmbling tufts of cotton from the protrusion of the hypogynous bristles beyond the glinmes,

\section{Eriophorum polystachyum, L.}

CotTon-WeEd, from its soft white pubesccucc,

Gnaphalium, I.

Covch-Grass, or Quitch, A.S. cwice, from cwic, vivacious, L. Germ. quek, quik, or queek, on account of its tenacity of life, for, as says the Bremen Glossary (rol. iii. 
p. 401), "Kein gewächs hat mchr lebenskraft als der Queck, wie die land- und garten-bauer mit verdruss erfahren," a name given to several creepiug grasses, but more especially to Triticum repens, L. and Agrostis alba, L. var. stolonifera.

CovgH-wort, a translation of G. $\beta \eta \chi \iota 0 \nu$, a name given to it from its medicinal use, the colt's-foot,

\section{Tussilago Farfara, L.}

Coventry-Bells, from their abundance near that town (Ger. em. p. 448), Campauula Trachelium, L.

Coventry RaPES, see RAMpion, called rape from its tuberous turnip-like roots, Campanula Rapunculus, L.

Cowbane, from its supposed baneful effect upon cows, the water hemlock,

Cicuta virosa, L.

Cowberry, apparently from a blunder between Vaccinium, the fruit of the whortle, and vaccinum, what belongs to a cow,

Vaccinium Vitis idæa, L.

Cow-cress, a coarse cress, Lepidium campestre, L.

Cowslip, A.S. cuslyppa or cusloppe, which O. Cockaync (Leechdoms, ii. p. 379), would derive from cu, cow, and slyppa slop, an explanation of it which is by no means prołable. Still less so is Wedgwood's, who, in ignorance that cows do not eat corslips, would regard the last syllable as a corruption of leek. There is very little poetry in these popular names, and the word seems really to allude to a very humble part of dress. In the Stockholm medical M.S. it is spelt loousloppe, and evidently means "hoseflap," from Flem. lousss, hose, and lopp, flap. Such a name could scarcely have been given in the first place to the plant now called " cowslip," but was very applicable to the large oval flannelly leaf of the mullein, Adtam's flaunel, as it is called in some northern counties, from which it has been transferred to it through the Latin name Verlascum, which comprehended both the cowslip and the mullein. 
This view is confirmed by its French name bruielle.

Primula veris, I.

„ French- or Mountain-, P. Auricula, I.

"Jerusalem-, Pulmonaria officinalis, L.

Cow's Lungwort, sec Bullock's Luxgwort.

Cow-Parsley, or Cow-weed,

Chærophyllum sylvestre, $\mathrm{I}_{\mathrm{A}}$.

Cow-Parsnep, Heracleúm Sphondylium, L.

Cow-QUAKE, a word that would seem to have arisen from a confusion in German works between queck, lively, a name given to the couch grasses, and quäg, live-stock, cattle. 'Thus Bauhin tells us (Th. Bot. p. 9), that Quecligras, quitch, is so called by the Saxons [the people of Lower Germany] from the cattle bcing fond of it: "a jumentis qux ea herba delectantur; Queck enim ipsis 'jumentum' significat." The quaking grass is ranged by Tragus under these queck-gräser, and the similarity of $G$. queck and $\mathrm{E}$. quake has fixed the name upon this species. The four words are in fact identical, etymologically speaking, and mean "alive;" whence their various applications, as queck, quitch, quake, and quäg, to objects in which life and motion are conspicuous. Briza media, L.

Cow-weed, see Cow Parsley.

Cow-whEat, from its seed resembling wheat, but being worthless as food for man, Miclampyrum, L.

Crab, Sc. scrab, from A.S. scrobb, a shrub, implying a bush- or wild-apple, in the Grete Herball called a "Wood crabbe," and according to Turner (b. ii. p. $4 i$ ), "in the north countrc a Scarb-tre," Fr. in Cotgrave, pomme de boys,

Pyrus Malus, L.

Crab-grass, from its growing on the sea-shore, where crabs abound, and being supposed to afford them food,

Salicornia herbacea, L.

Crake-Berry, the crow-berry, O.N. kraka, a crot, whence Da. krake-bär, from its black colour, or, accord- 
ing to Dr. Johnston, in East. Bord. from crows eating it greedily,

Empetrum nigrum, L.

Crambling Rocket, a spmious crambe, or mustard (as vetchling is a spurious vetch), with the leaves of rocket,

Sisymbrium offieinale, L.

Cranberry, from its fruit being ripe in the spring, when the crane returns, Da. tranebcer, from trane, a crane, a name of late introduction, for Lyte calls them Marrish Whorts and Fenberries, and says (b. vi.c. 11) that "there is none other name for them known,"

\section{Vaccinium Oxyeoccos, L.}

Crane's-BILL, from the form of the seed vessel, Geranium, Is.

Crap, or Crop, buck-wheat, related to L.carpere. Crop in our old writers means a head of flowers, a cyma, and may have been given to this plant, as being thus distinguished from the cereal grains, which have no such conspicuous flowers. There is probably some prefix lost from the word.

Polygonum Figopyrum, L.

Crappe, in some works, for no obvious reason, applied to the ray-grass, Lolium perenne, $\mathrm{L}$.

Crazr, or Craiser, in Wiltshire and the adjoining counties, the buttercup, apparently a corruption of Christ's eye, L. oculus Christi, the medieval name of the marigold, which, through the confusion among old writers between callha and calendula, lias been transferred to the marsh marigold, and thence to other ranunculacex. Thus in M.S. Sloane, No. 5, Oculus Christi is explained "calendula, solsequium, the Seynt Marie rode;" see Ruddes; and again, Gesner explains Caltha, which usually meaus the marsh marigold, "ringrel-bluom, solsiu, quod solem sequatur, vulgo calendula, quasi calthula. See Mrarrou.

Ranunculus, L.

Cress, a word that is found in all the Germanic languages from the earliest times, and adopted into the 
Romanie and other dialeets, but of which the origrin is unknown, in Gower and Chaneer kers, used absolutely it means the genus Lepidium, L. " Beldeisle-, Barbarea precox, liß. " Bitrere-, Cardamine amara, $\mathrm{L}$. " Garden-, or Town-, from its eultivation in tounes, i.e. euelosures, or gardens, Lepidium sativum, L. "LAND-, in distinetion from the water-eress, Barbarea vulgaris, RB. "Penny-, from its round silieules, Thlaspi arvense, L. " Sctatica-, from its medieinal use, Iberis, L. "Swine's-, or Wart-, Senebiera Coronopus, Poir. "WALL-, from its usual plaee of growth,

$\begin{array}{lr} & \text { Arabis, L. } \\ \text { " Water-, } & \text { Nasturtium offieinale, RB. } \\ \text { Winter-, } & \text { Barbarea vulgaris, RB. }\end{array}$

Crocus, Gr. крокоя, saffron.

Crioss of Jerusalem, from the resemblanee of its searlet petals, both in shape and colour, to the arms of a Maltese or Jerusalem eross, Lyehnis ehaleedoniea, L.

Cross-Flower, from its flowering in Cross-rweek. See ROGATION FLOWER.

Polygala vulgaris, L.

Cross-wont, from its erueiate or eross-plaeed leaves,

Galium erueiatum, Seop.

Crow-BELLs, that of Lyte, the daffodil,

Nareissus Psendonareissus, L.

" of Aubrey's Wilts, the blue-bell,

Seilla nutans, Sm.

Crowbenry, from the blaek eolour of its fruit, or from crows feeding on it, Empetrum nigrum, L.

Crowfrower, of Gerarde, Lyehuis flos eueuli, L.

Crowfoot, or Crowflower of later works, the buttereup, supposed from the shape of the leaf to be the Coronopus or erow's-foot of Dioseorides, Rinuneulus, $L$. 
Crowroot Cranesible, a geranium with a lcaf like that of a crowfont, Geranium pratensc, L.

Crow-Garlick, a worthless one, Allium vineale, L.

Crotr-LewKs, Scilla nutans, Sm.

Crow-needles, or Crake-needles (Ray) from the long beaks of the sced vessels, Scandix Pecten, L.

Crow-Toes, from its claw-like spreading legumes,

Lotus corniculatus, L.

Cuckosd, the burdock, a corruption of cockle, Arctium Lappa, L.

Crckoo's BRedD, or Cuckoo's meat, or GowK-Meat, from its blossoming at the season when the cuckoo's ery is heard, M.Lat. of Ort. Sau. c. xviii., panis cuculi, Fr. pain de concou, the wood sorrel, Oxalis Acetosella, L.

"Cuскоо вuds of yellow hue," Shaksp. (L.L.L. v. 2), are probably the buds of the crowfoot.

Cuckoo Flower, a name given in old works to the ragged robin, Lychnis flos cuculi, L. but now more generally to the lady's smock, whieh, as Gerarde says (p. 203), "Howers in April and May, when the cuekoo doth begin to sing her pleasant notes without stammering,"

Cardamine pratensis, L.

Cucroo Grumifower, one of the plants formerly comprehended under the gilliflowers, and blossoming at the time of the cuckoo's song,

Lychnis flos cuculi, L.

Cuckoo-grass, a grass-like rush flowering at the time of the cuelioo,

Luzula campestris, L.

Ctckoo-pint, or -pintle, from A.S. cucu, lively, and pintle (see Bailey), L.Ger. pintel, Fris. pint and peynth, words explained in Outzen's Glossary, a plant so called from the shape of the spadix, and its presumed aphrodisiac virtues. See below, WAKE-PINTLE and WAKE-RoBin.

Alum maculatum, L.

Cuckoo sorrist, A.S. geaccs sure, the wood-sorrel, from its flowering at the scason when the cuckoo sings,

Oxalis Acetosella, L. 
Cucumber, lix. concombre, It. cocomero, L. cucumis, -eris, C. sativus, I.

Cudbear, from a Dr. Cuthljert Gordon, who first manufactured a dye from it, Lccanora tartarca, Achar.

Cudweed, from cut, Du. Kutle, A.S. cwi $\delta$, vulva, a jlant that on account of its soft cottony pubescence was used to prevent chafings or to relieve them (see Cinfriremu).

Gnaphalium germanicum, and uliginosum, $\mathbf{W}$.

"SEd-, Diotis maritima, $\mathrm{L}$.

Cull-me-, Cuddle me-, or Call me to yot, sec Paxsy.

Curlions, It. coglione, augm. of coglia, L. colens, from its double tubers,

Orchis, L.

Colrage, through the French from L. culi rabies, a plant so named, says Gerarde (p.361), "from his operation and effect when it is used in those parts." See Lobel, Adv. Nov. p. 134. Picrs of Fulham says:

"An erbe is cause of all this rage

In oure tonge called culrage"

Polygonum Hydropiper, L.

Culverkeys, a name found in Walton's Angler, and the same probably as Calverleys, in Awbrey's Wilts, one now no longer used or understood. Being applied to a meadow plant it cannot be, as supposed by the commentators, the columbine, but far morc probably, as suggested by Mr. Edw. King, in Notes and Queries, 2nd S. rii. 303, the blue-bell or common hyacinth. Scilla nutins, Sm.

Culverfoot, in Lupton (b. ix. no. 15), the dores-foot crancsbill, Geranium columbinum, L.

Culverwort, A.S. culfie, pigeon, and roort, from the resemblance of its flowcrs to little heads of such birds feeding together, the columbine, Aquilegia rulgaris, L.

Cumme, from Ar. al qanoun, Cuminum cyminum, $\mathrm{L}$.

Cup in Butter-cup, King-cup, and Gold-cup, not from a drinking vessel, but from the resemblance of its double 
variety to the gold liead of a button, O E. cop, a stud, Fr. bouton d'or, Ranunculus acris, L.

Cup Licher, or Cup-Moss, from its eup-like shape, Scyphophorus pyxidatus, Hook.

Crrrant, a name transferred from the small grape brought from Corinth, and thenee ealled Uva Corinthiaca, to the fruits of several speeies of Ribes,

R. rubrum and nigrum, L.

Cushion-pink, from its dense tufted growth, and the resemblanee of its flowers in their general appearanee to pinks,

Statice Armeria, L.

Cut-HEal, the valerian, which was probably so ealled from its supposed effieaey in uterine afteetions, O. Du. lutte, A.S. cwid, matrix, O.E. cowth, and kutte, see Stratmann, but in mistaken eonformity to its name, used, as Gerarde tells us, "in sleight euts, wounds, and small hurts,"

Valeriana offieinalis, L.

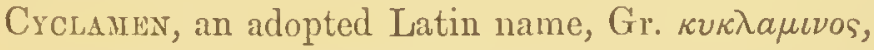

C. europæum Is.

Cyderaci, the eulrage. See Ciderage.

CrPuel, an unexplained name, possibly the Gr. $\kappa \nu \phi \epsilon \lambda \lambda a$, a mass of elouds, from its growth on cloud-eapped Alpine licights,

Cherleria sedoides, L.

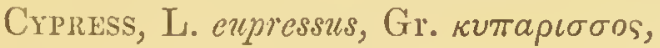

C. sempervirens, L.

Crptess-Root, or Sweet Cypress, from L. cyperus, a plant the aromatie roots of which are known as Linglish. golingale,

Cyperus longus, L.

Daffadowndily, Daffodilly, Avfodilly, and DaffoDIL, I. asphodelus, from which was formed Afforlilly, the name of it in all the older writers, but subsequently eonfused with that of another flower, the so-ealled sapharounor saffron lily. 
"The thyrde lylye gyt there ys, That ys called felde lylye, y wys, Hys levys he lyke to sapharoun, Men know yt therby many one."

MS. sloane, No. 1571.

With the taste for allitcration that is shown in popular names the Sapharoun-lily, upon blending with afforlilly, beeame, by a sort of mutual compromise, daffadlowin-dllly, whence we get our rluffortilly and dafforlit. 'This cxplanation of it is merely eonjcctural, and wants the test of historical evidence, but appears to be the best. 'The dictionaries derive it from "fleurs d'affodille;" but there is no such name to be found in any work, Freneh or English, and it is highly improbable that a plant should be called the "flowers" of the plant. Neither does this explain the -down- of Daffadlowndilly. Nareissus Pseudonarcissns, L.

$\mathrm{D}_{\Delta \mathrm{ISY}}$, A.S. doeges-eage, eye of day, O.E. duieseyghe, from its opening and closing its flower with the daylight, a name that seems to have delighted Chaucer, who, in the Lcgend of Good Women, line 40, and elsewhere, makes long and repeated allusions to it, Bellis perennis, L.

, Greate, or Moon-, or Ox-EYE-,

Chrysanthemum Leucanthemum, L.

" Mrchaelias-, from its season of flowering,

Aster Tradeseanti, L.

, SEa-, Almeria maritima, IV.

Damask Vrolet, or Dame's Violet, L. Fiola Damascena, from Damaseus in Syria, Fr. Tiolette de Damas, misunderstood for Fiolette des dames. The name has probably come to us from Italy, where that of violetta is not so usually given to the genus viola, as to certain swcetscented crueiferous plants of the gencra Matthiola, Hesperis, and their allies.

Hesperis matronalis, $\mathrm{L}$.

Damsons, Damasins, or Damask prunes, Fr. damascene, a lind of plum first brought from Damascus,

Pruuus communis, Huds, var. damaseena. 
Danderion, Fr. dent de lion, lion's tooth, L. leontodon, a name, about the meaning of whieh modern authors are undeculed. Some derive it from the whiteness of the root; some from the yellowness of the flower, whieh they eompare to that of the heraldic lion, whose teeth are of gold; most of the Herbalists from the runeinate jags of the leaf, which somewhat resembles the jaw, but eertainly not a tooth of the lion; others from other grounds more or less plausible, but all to the negleet of the only safe guide in these inatters, the ancient writer who gave the name. We learn from the Ortus Sanitatis, eh. 152, that a Master William, who was a surgcon, and who seems, from eh. 226, to have written a "eyrorgi," or work on surgery, was very fond of this plant on aceount of its virtues, and therefore likened it to a lion's tooth, ealled in Latin dens leonis. "Diss kraute hat Meyster Wilhelmus, eyn wuntartzet gewest, fust lieb gehabt umb seiner tugent willen, unnd darumb hatt er es geglichen eynem leuwen zan, genaut zu latein dens leonis." Ld. Augsburg, 1486, fol. It bears a similar name in nearly every Europcan language.

Taraxacum offieinale, Vill.

Danewort, Daneweed, or Danesweed, names of the dwarf elder for whieh Awbrey in his Nat. Hist. of Wilts, p. 50, substitutes that of DANESBLOOD, and gives an explanation of it that seems to be a faneiful one, seeing that the plant bears the same name of "Danesweed" in other eounties, viz. that it grows in great plenty about Slaughterford, where there was a great fight with the Danes. Parkinson (Th. Bot. p. 208) derives it with more probability from the aptness of the plant to cause a flux called the Danes; but as it is expressly reeommended by Platearius as a remedy "eontra quotidianam," the Dane may be a eurruption of the last syllables of this word.

Sambueus Ebulus L.

Dapine, the name of a nymph, who was turned into a 
shrub by the other grods, when pursued l,y Apollo, Ovid. Met. i. 452.

D. Isaurerola, I.

Darnet, in Pr. Pm. Denciet, a name that in old writers did not mean exclnsively the large ray grass to which we now assign it, but many other plants also, of many different genera and natural orders, leguminosx, gramincex, and earyophyllex. Whether in the first place it was assigned to any one of them exelusively, eannot now be diseovered. Under Darnel our early herbalists eomprehended all kinds of eorn-field weeds. So in the Grete Herball, el., 24,6, we find under the pieture of a vetch (!), "Lolium is Cokyll." The A.S. version of Matth. elr. xiii. v. 25, renders the Lat. "zizania" coccel, Wycliff"s both cokel. and damel, and later versions tares, and 'Th. Nerton, in his Herbal to the Bible, p. 226, tells us expressly that, "under the name of Cockle and Darnel is eomprehended all vieious, noisome, and unprofitalle graine, eneombring and hindering good eorne." The origin of this word is extremely obseure, and all analysis of it quite eonjeetural. The impression that it always meant the grass that we now eall so has led etymologists to try to diseover in it the sense of intoxicating, which it was probably never intended to eonvey. Some ineidental notiee may another day throw a light upon it, that eannot he elieited by any amount of thought, or ingenuity of conjeeture.

Lolium temulentum, L.

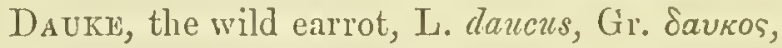

$$
\text { D. Carota, L. }
$$

Deaduay's Fingers, from the pale eolour and hand-like shape of the palmate tubers, Orehis maeulata, L.

Dead NetTle, Lat. of Ort. San. Urtica mortua, a plant that has nettle-like leaves, but does not resent the toneh with a sting, and from its apparent insensibility is ealled dead, deaf, and blind,

Lamium L.
9
WIIITE-,
L. album, L. 


$$
\begin{aligned}
& \text { " „ RED-, L. purpureum, L. } \\
& \text { " "Yelfow-, L. Galeobdolon, Cr. }
\end{aligned}
$$

DEAD-TONGUE, from its paralysing effeets on the organs of voice, of whieh Threlkeld gives a striking example, on the authority of a Mr. Vaughan, in the ease of eight lads who had eaten it, and of whom "five died before morning", not one of them having spoken a word," the Water Hemlock,

Ginanthe croeata, L.

Deadly Nightshade, cr Death's Herb, Atropa Belladonna, L.

Deaf Netthe, the Dead nettle, Lamium, L.

Deal-trees, the speeies of fir that produce the deal of eommeree,

Pinus and Abies.

DeEr's HaIR, from its tufts of slender stems looking like eoarse hair,

Seirpus exspitosus, L.

DeLT-ORACH, an orach whose leaves are triangular, like a Greek letter $\Delta$, Atriplex patula, L.

Deptrond Pink, from its growing, acording to Gerarde, "in a field next Deptford, as you go to Greenwieh,"

Dianthus Armeria, L.

Devil IN THE BUsh, from its horned eapsules peering from a bush of finely divided involuere,

Nigella damascena. L.

Devil's-Bir, G. Tenfels abbiss, L. Morsus diaboli, so ealled, says the Ortus Sanitatis, c. eelxi, on the authority of Oribasius, "beeause with this root the Devil practised such power, that the mother of God, out of eompassion, took from the Devil the means to do so with it any more; and in the great vexation that he had that the power was gone from him, he.bit it off, so that it grows no more to this day." Threlkeld reeords a legend, that "the root was once longer, until the Devil bit away the rest, for spite; for he needed it not to make him sweat, who is always tormented with fear of the day of judgment." Later authors explain it, as though the root would cure all 
diseases, and that the Devil, out of his invetcrate malice, grudges mankind such a valuable medicine, and lites it off.

Scabiosa succisa, L.

Devil's daRNing NeEdles, from its long awns,

Scandix Pecten, Is.

Devil's auts, from the resemblance of the stem to catgut, and the mischief it causes, the dodder, Cuscuta, L.

Devil's MiLK, from its acrid poisonous milk, Euphorbia, L.

DeVIL'S SNUFF-BOXES, Lycoperdon, L.

Dew-Berry, G. tauben-beere, Norw. col-lär, supposed to be eallcd so from the dove colour of its fruit, A.S. duru, Du. duif, a dove, but perhaps with better reason referrible to the theve-thorn of Wycliffe's Bible. See Theve-trons.

Rubus cæsius, L.

Dew-Grass, from its rough dew-besprent blades, the cocksfoot grass, Daetylis glomerata, $\mathrm{L}$.

Dewtry, from L. Datura (see Hudibras, pt. iii. c. 1. 1. 321 ), the thorn-apple, D. Stramonium, L.

Dili-SeED, from O.N. dilla, lull, being used as a carminative to cause children to sleep,

Anethum graveolens, L.

Diтсн-веR, called by Turner Dychebur, from its burlike involuere, and its growth on dykes, not in ditches, as its modern name would lead us to suppose, the dyke, Du. diik, bcing the dry bank that confines the water,

Xanthium strumarium, L.

DitTander, or DitTany, apparently a corruption of L. dictamnus, the name of a very different plant, but applied to a cress, of which Lyte says (b. v. ch. 66), "It is fondly and unlearnedly called in English Dittany. It were better in following the Douchemen to call it Pepperwurt." Lepidium latifolium, L.

Dock, A.S. docca, which seems to be the same word as Norw. dokka, G. docke, Dan. dukke, a bundle of flax or 
hemp, a word that corresponds to Fr. bourre, a floek, and O.E. harde or herde, explained by Batman or Bartholomew (e. 160), as "what is ealled in Latin stupa, and is the elensing of hompe or flexe." The name Dock would seem from this to have been first given to the burdoek from the frequent oeeurrenee of its involucres entangled in wool, and to have been transferred from this to other broadleaved plants. Used absolutely, it means at the present day those of the sorrel kind. See Burdock and Hardock. Rumex, L.

" Bur-, see under Burdock.

"FIDDLe-, from the shape of its leaves,

Rumex pulcher, $\mathrm{L}$.

" Round-, the common mallow, still ealled so in the eharm that is said to be used by children when stung with nettles, and supposed to be the plant alluded to by Chaneer in Troilus and Cressida (b. iv. st. 62): "Nettle in, doek out."

Malva sylvestris, L.

"Sharp-, or Sour-, the sorrel, from its aeidity, Rumex Acetosa, L. Verbaseum Thapsus, L.

Dodder, the plural of Fris. dodd, a bunch, Du. dot, hampered thread, from its resemblance to bunches of threads entangled in the plants on which it grows,

$$
\text { Cuseuta, L. }
$$

DODDER Grass, from the trembling of its spikelets,

\section{Briza media, L.}

Dogberry, or Dog-cherry, the fruit of the Dogwoorl tree, a name misunderstood as referring to the quadruped. See Dogwood.

Dog's Cramosnet, a spurious or wild kind,

Cornus sanguinea, $l$.

Matricaria Chamomilla, I.

Dori-Grass, ealled so, Tabcrnæmontanus tells us, "sintemal sich die Hunde, wenn sie Massleid haben, damit 
purgiren;" and R. Turner (Bot. p. 89), "It is culled in Latin gramen caninum, because dogss eat the grass when they are sick."

Triticum caninum, Ilud.

Dog's Mercuny, or Dog's Cole, a spurious kind, to distinguish it from the so-called English XIcrcury,

Mercurialis perennis, $\mathrm{L}$.

Dog's OracH, a stinking kind,

Chenopodium Vulvaria, L.

Dog's Parsley, Gr. kvvatiov, a worthless weed, parsley for a dog, $\quad$ Ethusa Cynapium, $L$.

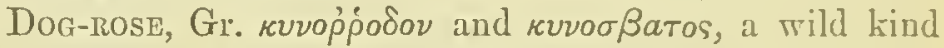
not valued for scent or beauty. It furnishes an instance of a tale written to a name: Pliny relates (1. xxv. c. 6) that a soldier who had been bitten by a mad $\log$ was healed with the root of this shrub which had been indicated to his mother in a dream. It bore the namc long before.

Rosa canina, L.

Dog's-TaIL-GRass, from its spike being fringed on one side only, Cynosurus cristatus, Is.

DOG'S-TONGUE, a translation of L. cynoglossum, a name given to it from its soft leaf, $\quad$ C. officinale, $L$.

DoG's-TOOTH-GRaSS, Fr. chien dent, from the sharppointed shoots of its underground stem,

Triticum caniuum, Hud. and Cynodon Dactylon, $\mathrm{P}$.

Dog-VIolet, a scentless onc, Viola canina, L.

Doa-woon, not so named from the animal, but from skewers being made of it. "It is rather a shrub than a tree," says 'Threlkeld, "the dry wood wonderfully resists the axe and the wimble, and is used for skewers by the butchers." Dog, in this view of it, is the Fr. dague, lt. and Sp. daga, Fl. and Old Engl. dagge, equivalent io G. dolch, a dagger, and A.S. dalc or dole, a fibulin, a broochpin, and related to Skr. dag, strike: "And forthwith they caused all the daggs and other weapons that the dukc's 
servants had in the louse to be sought out and sent away." From a letter dated $154 \mathrm{~S}$ quoted by Froude, in Hist. of Eng. vol. iv. p. 337. sm. Svo. The verb dawk is still retained in the Western eounties in a Nursery rhyme: "Priek it and dawk it, balier's man." This derivation of the name is supported by its synonyms Prick-wood, Skever-wood, and Gadrise, but bas been overlooked, and the fruit, from a mistaken idea of its meaning, called a Hound's-berry.

Cornus sanguinea, L.

Doob-GBASs, the name given in India to the dog's-toothgrass,

Cynodon Daetylon, P.

Dove's root, from the shape of the leaf,

Geranium molle, L.

Drane, Drawk, or Dravick, Du. dravig, W. drewg, Br. draok, darnel, cockle, or weeds in general, L. daucns, with insertion of $r$, as in Sp. tronar from tonar. It is sometimes found spelt drank, a form of the word whieh seems to have arisen, in the first place, from a mere misprint of $n$ for $u$. Bromus sterilis, and Avena fatua, L. etc.

Dropwort, according to Turner (b. iii. 3l), from its small tubers hanging like drops by slender threads, Spiræa Filipendula, L.

Dropwort, W WTER-, from its use in stillicidium, and growth in wet places,

Gnanthe fistulosa, L.

Dry-rot, a name given to several piees of fungus destructive of wood, which they render dry and as if destroyed by fire (see Proceedings of Linn. Soc. for 1850 , p. 80), but probably derived from tree, wood, and rot,

Merulius lacrymans, Wulf.

DUCK-MEAT ol-WEED, an aquatie plant, a favourite food of ducks, called in Pr. Pm. ende-mete, Du. eenden-groen, Lemna minor, L.

Dulsa, Gael. duillisg, from dnille, leaf, and uisge, water, a name given to several species of rose-spored algre, and more especially to

Rhodomenia palmata, and Iridxa edulis, B. St. V. 
Dunse-Down, a plconasm, from Du. dons, whicli means "down," so called from its soft spikes, but whimsically" derived by Lobel from its making people dunch or deaf; if it gets into their cars (Kruydtb. p. 113), an opinion that is advaneed by Rob. Constantine also, who says: "Italis mazza sorda; cjus cnim paniculse flos si aures intraverit, cxsurdat," the reed-mace, Typha latifolia, L.

Dutch Clover, or simply Dutch, from the seer of it having been very largely imported from Holland, 150 tons annually, says Curtis in his Flor. Lond.,

Trifolium repens, L.

Dutch Myrtle, L. Aryrtus Brabantica, from its abounding in Dutch bogs, and replacing the myrtle of more genial climates, Myrica Gale, L.

Dutch Rush, a rush-like plant imported from Holland, Equisetum hyemale, L.

Dwale, Da. dzoale, torpor, trance, whence dwale-lcer, a dwale- or trance-berry. In Chaucer (Recres T. 241), it is used for a sleeping draught: "There nedeth him no dwale;" and in Lupton's 1000 notable things, we have (b. iv. 1) a receipt for making Dwale for a patient to take, "while he be cut, or burned by cauterising," the ingredients of which are the juices of hemlock, nep, lettuce, poppy, and henbane, mixed up with pig's gall and vincgar. Once a general term, it has been appropriated to the deadly nightshade. Atropa Belladonna, L.

Dyer's GREEN-WEED, a weed, in the sense of a dye-herb, that tinges green,

Genista tinctoria, L.

Dyer's ROcKet or Yellow wEed, from its leares resembling those of the genuinc rocket, and its being used by the dyers to dye woollen stuffs yellow, sec BASE-ROCKET, Reseda Luteola, L.

Eartif-Balls, trufles, balls that grow under the carth, 'Tuber cibarium, Sib.

Earth-Call, A.S. eordgealle, from their bitterness, 
plants of the gentian tribe, more particularly the lesse $1^{\circ}$ centaury,

Earth-moss, Erythræa Centaurium, L.

Earth-nur, or -chestnut, Ennut, or Yernut, from its nntty esculent tubers, Bunium flexuosum, With.

Earth-SHoke, L. fumus terre, see Fumitory,

Fumaria officinalis, L

EARTH-STAR, a fungus so called from its stellate shape when burst and lying on the ground, Geaster, Berk.

Eglantine, a name that has been the subject of much discussion, both as to its exact meaning, and as to the shrub to which it properly belongs. In Chaucer and our other old poets it is spelt Eglantere and Eglatere, as in a passage in the Flower and Leaf, st. 3 :

The hegge also, that yede in compas,

And closed in all the greene herbere,

With sicamour was set and Eglatere.

But whether this word meant originally the sweetbrier, the yellow rose called in systematie works Eglanteria, the dogrose, the burnet rose, or some other speeies, cannot now be ascertained, and perhaps the poets who used it meant no more than a rose of any kind indifferently. Indeed, Milton in the expression "twisted eglantine," is supposed to have meant the woodbine. The derivation of the name is obscure. Diez, the highest authority in questions of French etymology, derives it from Lat. aculeus, a prickle, through aculentus, whence O. Fr. aiglent, covered with prickles, and aiglentier, which became églautier, and églantine, and in this view is supported by Brachet and Littré. In ancient French works it seems to have been given to the wild roses. In our own early writers, and in Gerarde and the herbalists, it was a shrub with white flower's that was meant. At the present diay by Eglantine is usually understood the sweet-brier, Rosa rubiginosa, L.

Elderi, A.S. ellen and ellarn, in Pierce Plowman eller, 
words that seem to mean "kindler," and to be derived through A.S. celd, Da. ild, Sw. eld, fire, from celan, lindle, and rchated to Du. helder, elear, whence op-helderen, kindle or brightcn up; a name which we may suppose that it acquired from its hollow branches being used, like the laamboo in the tropies, to blow up a fire;

Sambucue nigra, $L$.

DwarF-,
"Water-, Sambucus Eluulus, L. Viburnum Opulus, L.

Elecampane, L. Emula campana, by countrymen, says Isidore, ealled Ala campana, the latter word from its growing wild in Campania, the former from L. Inula, a word of uncertain derivation, Inula Hclenium, $L$.

Eleven o'clock lady, Fr. dame d'onze heures, from its waking up and opening its eyes so late in the day, the star of Bethlehem,

Ornithogalum umbellatum, L.

ELF-Dock, the elecampane, from its broad leaves called a llock, and from some confusion between its Italian name, ella, and the Dan. elle, an elf, deriving its prefix,

Inula Helenium, L.

ELrr, a word that is nearly identieal in all the Germanie and Scandinavian dialeets, but does not find its root in any of them. It plays through all the vowels, Ie. Almr, Da. $A l m$, $A l m$, and $E l m$, A.S. and Engl. Elm, Germ. in different dialeets $I l m e, O l m$, and Ulme, Du. Olm, but stands isolated, as a foreign word, whieh they have adopted. This is the Lat. Ulmus, the terminating syllable of which, mus, indicates an instrument, a material, or means, with which something is done; while the first secms to be the $u l$ of ulcus, sore, and ulcisci, punish, in allusion to the common nse of rods of clm for whipping slaves. Sec Plautus (Asin. $2,2,96)$. The foreign origin of the name indicates that the trec was introduced into England from the Soutl of Europe, and explains what Aubrey remarks in his "Wilts," that in the Villare Anglieum, although there are a great 
many towns and villages named after other trees, there are only three or four Elme-tons.

Ulmus, L.

Eyony, the anemony misunderstood as An Emony. "Gardeners commonly call them Emonies." R. Turner. Bot. p. 18.

Anemone, L.

Eichaxter's Nightsiade, a name that, by some blunder, has been transferred from the mandrake, Atropa Mandragora, to an insignifieant garden weed. The mandrake was ealled Nightshade from having been classed with the Solana, and Enchanter's from its Latin name Circcea, Gr. кьркаıа, given to it after the goddess Circe, who bewitehed the companions of Ulysses with it (Od. b.x.); or aceording to Dioscorides, as quoted by Westmacott, p. 105: "Twis ealled Circæa, because Ciree, an Enchantress expert in herbs, used it as a Tempting-powder in amorous coneerns."

C. lutetiana, $\mathrm{I}$.

Exdrve, Iт. and Sp. endivia, I. intybea, adj. of intybus, Cichorium Endivia, L.

Exglish Meroury, a plant reekoned among the Mercuries, but why called English more partieularly, we are not told, Chenopodium Bonus Henriens, L.

Ers, the bitter vetch, Fr. ers, L. ervnm, E. Ervilia, L.

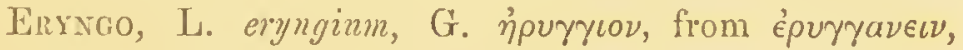
eructare, being, according to the herbalists, a speeific against that inconvenience, E. maritimum, L.

Euphrasy, Milton (P. L. xi. 1. 414), Stockholm Med.

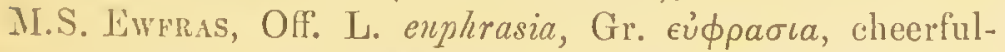
ness, a name that C. Bauhin with great probability tells us was first given to the bugloss, meaning probably the horage, and which has been transferred to the eyebright,

Euphrasia offieinalis, L.

Jiring prinrose, from its pale yellow colour and its opening at sunset,

Qinothern biennis, L.

Everdasting Flower, from its retaining shape and colour when dried,

Gnaphislinm, L. 
Everlasting pea, Fr. pois eternel, from not leing, like the eommon and the sweet pea, an annual,

Latliy rus latifolius, L.

EYE, the pink, in Tusser ealled "Indian eye," I. ocellus, as in the name of the earnation, ocellus Damascenus, from the eye-shaped marking of the eorolla, Dianthue, L.

Eyebright, so ealled, as W. Coles tells us in his Adam in Eden, from its being used by the linnet to clear its sight, and thenee adopted by men. Where he picked up this tale, does not appear. It is one of several similar legends. See Cerandine, Hawnweeil, and Pigeon's grass. We may add to this number of eye remedies learnt from the birds, that the use of fennel was tanght to man by serpents :

Hac mansa serpens oculos caligine purgat:

Indeque compertum est humanis posse mederi

Illam luminibus, atque experiendo probatum est.

Macer. c. xvii. l. 4.

We are told the same of the eagle, in referenee to the use of the wild lettuee: "Dieunt aquilam quum in altum volare voluerit, ut prospieiat rerum naturas, Laetucæ sylvatiex folium evellere, et sueeo ejus sibi oeulos tangere, et maximam inde elaritudinem aecipere." Apuleius, e. xxx. The plant was long in vogue as a remedy in diseases of the eye. Brunsehwygk tells us in his quaint old German: "Es was oueh ein liüngin in Engelant, die brant allein das wasser uss der blumlin, und thett wunderliehe ding darmit zů der ougen, als mir der selbigen küngin artzet geseyt hat." See Éuphrasx.

Euphrasia offieinalis, L.

Exebrigut Cow-wheat, a plant in some respects resembling both the eyebright and the eow-wheat,

Bartsia Odontites, Hud.

Fair maids of Februari, snowdrops, from their white blossoms opening about the 2nd of that month, when 
maidens dressed in white walked in proeession at the feast of the Purifieation,

Galanthus nivalis, L.

Fair maids of France, a donble-flowered variety of erowfoot introduced from France,

Ranunculus aconitifolius, L.

Fairy Butrer, a fungus so ealled in the northern eounties from its being supposed to be made in the night, and seattered about by the Fairies. Atkinson Clev. Dial, p. 169. Tremella arborea and albida, Sm.

Fairy Flax, a flax so ealled from its delieaey,

Linum eatlia'tieum, L.

FAllen stars, from their sudden appearanee glittering on gravel walks after a night's growth, and the vulgar opinion of their origin, certain gelatinous alga, and partieularly

Nostoc Commune, Ag.

Faxcy, an attempted explanation of Pansy,

Viola trieolor, L.

Fat Hen, G. Felle Henne, a name given in Germany and by the older herbalists to the orpine, Sedum teleplium, called also faba crassa, fat bean, but without any reason assigned. It has been of late years transferred in Engrland to plants of the Goosefoot tribe, and morc partieularly to the Good Henry, whieh a eorrespondent of Seeman's Journal (vol. i. p. 15l), asserts to have been used formerly for fattening poultry; a statement which requires confirmation, as there is no other English or foreign writer who mentions any such use of the goosefoots, or the orpine.

Chenopodium Bonus Henrieus and Atriplex patula, L.

Feabe, Fape, Fabe, 'Thape, Theabe, De-, Fae-, Fea-, or FEAP-BErRy, different forms of an East Anglian very obseure name of the gooseberry. An interehange of an initial $f$ and $t h$ is not uneommon. We find it, for instanec, in the verb fly, Go. pliuhan, O.H.G. Riohan, G. fliehcn; and in thalches, a dialectic pronunciation of vatches, i.e. 
filches or veleles, to be lieard in some parts of Somerset. The name seems to have attached itself to the grooseluerry through one of those blunders that have arisen from lad pietures. The melon, G. pfele, L. pepo, is so figured in Tabernæmontanus (vol. ii. p. 184.), as to look exactly like a gooseberry, and headed Pfele, and from this, or an equally bad pietnre, the name may have been adopted. Loudon (in Arbor. Brit. ii. p. 972), eonsiders it to be meant for fever-berry, a very improbable explanation. Wright would derive it from A.S. pefe-porn. The use of the term seems to be eonfined at present to the eastern counties, where the green unripe fruit is called Thape, as in a word well known to Norfolk sehoolboys, Thape-pie.

\section{Ribes Grossularia, L.}

Feather-few, Fedder-few, or Feather-fully, in Pr. Pm. Feder-For, the feverfer, through a ehange of $v$ to $t h$, and probably also from eonfusion of name with the featherfoil, Pyrethrum Parthenium, L.

Featirer-forl, feathery leaf, from feather and, foil, a name deseriptive of its finely divided leaves.

Hottonia palustris, L.

Featier-grass, from its feathery awn,

Stipa penuata, L.

Feldwode, Gower (Conf. Amant, bk. v. p. 262), who says of Medea :

"Tho toke she feldwode and verveine,

Ol' herbes ben nought better treine."

The plant is supposed by the editor, Dr. R. Pauli, to be the baldmoney, the yellow gentian, A.S. and O.E. feld weyrt,

Gentiana lutea, L.

but is possibly the hag-taper, or mullein, A.S. feltacyrt, See Coekayne (vol. ii. p. 384 and vol. iii. p. 326).

Verbaseum Thapsus, L.

Fetwort, the gentian, a name that looks like an anomalous eompound of L. fel, gall, and worl, but apparently is 
a mndified form of A.S. fell-wyrt, whieh there is little doubt arose from a eonfusion between L. fel and A.S. feld,

Gentiana, L.

FELON-WOR', or -wood, the bittersweet, from its use in euring whitlows ealled in Latin furunculi, little thieves, that is, felons, Solanum Dulcamara, L.

Fen-Berky, from its growing in fens, the eranberry, Vaeeinium Oxyeoeeos, L.

Fex-Rue, from its divided rue-like leaves and plaee of growth,

Thalietrum flavum, L.

Fenkel, and Fennel, M. Lat. fanculum, from L. feniculum, F. fenouil,

F. vulgare, Gärt.

„DoG's-, from some similarity of its leaf to fennel, and its bad smell,

Anthemis Cotula, L.

Fenvel-lilower, from its fennel-like finely divided leares,

Nigella damaseena, L.

FEne, A.S. fearn, G. farnkraut, Du. varenkruilt, a word of obseure origin, but from the appended kraut and kruidt to the G. and Du. synonyms, one that seems to be expressive of some use or quality. It has been, with great plausibility, referred to forms of the word feather, G. feder, Sl. pero, Gr. $\pi \tau \epsilon \rho \iota$ and $\pi \tau \epsilon \rho o \nu$, and suggested that it may be eonneeted with Skr. parna, which means both a leaf and a feather, and with L. frons. It seems a more easy and natural explanation of the word to traee it to the use of thuse plants for littering eattle, A.S. fear, G. forr, Du. var, a bullock, in which the eliange of the letters exactly eorresponds to that which takes plaee in the names of fern in the same languages. It might also be eonneeted with the name of the pig, A.S. feark, Du. varken, G. ferkel and ferken, L. verres, Skr. varälia. Matthioli (l. iv. c. 179), speaking of Pteris, and Filix mas, says: "Utriusque radiee sues pingueseunt;" and in a eharter of A.D. 855, in 'l'horpe's Diplomatarium, p. 113, pascua porcorum is translated fearnleswe. In some old German works the 
word is rarm, and as the Scandinavian name is orm-gris, worm- or snakc-grass, from the involuted vernation of the frond, it may be wortl eonsideration, whether these words, varm and orm, may not be the Lat. vermis, and farn a corruption of it. But, as J. Grimm says, "tiofes dunkel ruht auf der wurzel."

Filix.

Fern, Bladder-, from its small vesicular sporc-cases,

Cystopteris, Ber.

, Bristue-, from the bristle that projects beyond its receptacle, Trichomanes, Sm.

" Female-, of old writers, not the species now called Lady-fern, but the brakc, from Gr. $\theta \eta \lambda u \pi \tau \epsilon \rho \iota s$, a name that is now assigned to another one different from both of these. That of the herbals is Pteris aquilina, L.

, Filsy-, from its transparent filmy texturc, Hymenophyllum, L.

„Finger-, Ceterach officinarum, TH.

„, Flowering-, from its conspicuous spilies of fructification,

Osmunda regalis, $\mathrm{L}$.

"HARD-, from the rigid texturc of the frond,

Blechnum borcale, Sm.

, Holly-, from its prickly fronds,

Aspidium Lonchitis, S $\pi$.

"LADY-, a mere translation of filix foemina, a former Latin name of the brake, Gr. $\theta \eta \lambda v \pi \tau \epsilon \rho \iota s$, which was given to it from some caprice, and without refercnce to scx as now understood, and has been transferred to the spccies now called so, for no better reason than the delicacyof its foliage, Asplenium Filix fœmina, Bcrn.

"Mander-Harr-, Adiantum Capillus V'cncris, L.

„Male-, a translation of its old Latin name, Aspidium Filix mas, Sw.

"Marsh-,
, Mountain-, Aspidium Thelypteris, Sw. Aspidium Orcopteris, ST. 
,Osk-, of modern botanists,

Polypodium Dryopteris, L.

" $\mathrm{O}_{A K}$, of the herbalists, with a belicf that such plants of it as grew upon the roots of the oak-trce, were of greater medicinal power: "quod nascit super radices quercus, cst efficacius:" (Herbarius, e. 103.) the common polypody,

Polypodium vulgare, L.

" Parsley-, Allosorus erispus, Bern.

"Scaly-, from the scales on the fiond,

Ceterach officinarum, $\mathrm{W}$.

"Shield-, from the coverings of its spore-cases,

Aspidium Sw.

"WALL-, from its ordinary place of grorth,

Polypodium vulgarc, L.

Fescue, from the L. festuca, by change of $t$ to $c$,

F. ovina, I. etc.

Feveraw, L. febrifuga, from its supposed febrifugc qualities,

Pyrethrum Parthenium, L.

Field Cypress, the ground pine, from its. terebinthinate odour and divided leaves,

Field Madder,

Fig, Fr.figue, L. ficus, Ajuga Chamæpitys, Schr.

Sherardia arvensis, I.

Fra-WorT, from its use, on the doctrine of signatures, in the disease called ficus,

Scrophularia, L. and also, for the same reason, Ranunculus Ficaria, L.

Finbert, formerly spelt Filberd, and Fylberde, said by some to have been so called after a king Philibert; by Wedgrwood explained as Fill-bearl; but more probably a barbarous compound of phyllon or feuille, leaf, and beard, to denote its distinguishing peculiarity, the leafy involucre projecting beyond the uut, Corylus Avellana, Is.

Finскцe, G. fenchel Du. venkel, from I. feniculum, fenncl,

F. vulgare, I.

Fivger-trower, G. finger-hul, L. digitalis, from the re- 
semblanee of its flower to a thimble or the finger of a glove,

Fiorin, Fise fearh, grass, D. purpurea, Is.

I'In, O.H.G. furaha, Dan. fyrr, Sw. furu, the fire-tree, the most inflammable of woods. Etymologically the word is identieal with L.quercus, the initial qu laving, as in quinque, an $f$ for its representative in the Gormanic languages. See Max Müller, Lectures, 2nd course, p. 221.

Pinus and Alies.

"Scorch-, from its being found indigenous upon the mountains of Seotland, P. sylvestris, L.

"Siluver-, from the white under-surface of its leaves, P. Picea, L.

„SPrtck-, from G. sprossen, sprout, see Sprticr, Abies exeelsa, Poir.

FIR-Moss, a mossy looking plant like a little fir-tree, Lyeopodium Selago, L.

Fist-Balts, A.S. fist, G. feist, Du. veest, erepitus, Norw. fissopp and fisball. See Puckrist. Lyeoperdon, L.

Fiтch, an old spelling of Veteh, Vieia satira, L.

Five-pinger-grass, or Five-Lear, Sw. finger-ört, Gr.

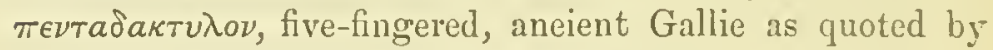
Dioseorides (iv. e. 42), $\pi \epsilon \mu \pi \epsilon \delta o v \lambda a$; by Apuleius (e. 2), pomperlulon; a word meaning five-leaf, a plant so ealled from its five leaflets,

Potentilla reptans, Sib.

FlaG, from its petals hanging out like banners; properly the speeies of

$"$ Conn-,
Swent-,
Yellow-,
Iris, L.

Gladiolus, L. Aeorus Calamus, L. Iris Pseudaeorus, L.

Flamy, in Miss Kent's Flora Domestiea given as a name of the pansy, and explained "beenuse its eolours are seen in the flame of wood." It is the translation of Lat. Fiola Rammea.

V. tricolor, L.

Flaw FLow Hir, from flaw a gust of rind, a translation 


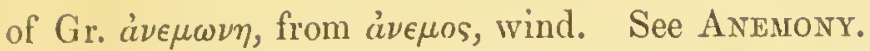
Anemone Pulsatilla, L.

Fldx, G. flachs, Du. vlas, Fr. filasse, M. Lat. filassium, yarn, from filare, spin, L. filum, a thread,

Linum usitatissimum, L.

Flax, Dwarf-, or Purging-, or Fairy-,

L. eathartieum, I.

"TOAD-,

Linaria vulgaris, L.

FLAX-SEED, from the resemblanee of its seed-pods to flax bolls, Radiola Millegrana, L.

Flax-weed, from its leaves resembling those of flax, Linaria vulgaris, $\mathrm{L}$.

Fled-BaNe, from its supposed power of destroying fleas, Inula Pulicaria, L. "BLUE-, Erigeron aere, L.

FLEA-WORT, from its keeping off fleas,

Inula Conyza, DC.

Fleur de lis, see Flower de Luce.

Fux- or FLUX-WEed, from its use in dysentery, a disease that was formerly ealled fii.

Sisymbrium Sophia, L.

FlodT- or more properly Flote-grass, not so mueh from its floating on the surfaee of the water, as from its abounding in floted, or irrigated meadows,

and also in some works

Poa fluitans, Seop.

Alopeeurus genieulatus, and Catabrosa aquatiea, L.

Florimerr, or Floramor, Fr. fleur d'amour, from a misunderstanding of its Latin name, Amarantus, as though a eompound of amor, love, and anthus flower,

A. eaudatus, and trieolor, $\mathrm{L}$.

Flower de Luce, Fr. fleur de Louis, from its having. been assumed as his device by Louis VII. of Franee: "Ce fut Louis VII. dit le Jeune, A.D. 1137, qui ehargea l'éeu de Franee de fleurs de lis sans nombre," Montf. 'The 
flower that he ehose seems to have leeen a white ore; for Chaueer says (C. T., Prol. 238) :

His nekke whit was as the flour-de-lys:

and there is a legend that a shield chargerl with these flowers was brought to Clovis from hearen while engraged in a battle against the Saraeens (H. Pyne, England and Franee in 15th cent. p. 23). It had already been used by the other French lings, and by the Emperors of Constantinople; but it is a question what it was intended in the first plaec to represent. Some say a flowcr, some a halbert-head, some a toad. See Notes and Queries, 29 Mar. 1856. Fleur de Louis has been ehanged to Fleur de Luce, Fleur de lys, and Fleur cle lis.

Iris, L.

Flower of Bristow, or -of Constantivople, the searlet lychnis, the latter name from its growing wild near the Turkish capital, the former from its colour being "Bristol red," as in Skelton's poem upon Eleanor Rumming :

"Her kirtle Bristow red."

Sce Chambers's Book of Days, i. p. 801.

Lyehnis ehaleedonien, $\mathrm{L}$.

Frower gentle, the floramor, Fr. in Cotgrave la noble fleur, from its resemblanee to the plumes worn by people of rank,

Amarantns tricolor, I.

Flowerivg Fern, from its handsome spikes of fructifieation,

Osmunda regalis, $\mathrm{L}$.

Flowertivg Rush, L. juncus floridus, a plant with a rush-like stem, and growing in the watcr, with a fine head of flowers, called by Lobel Juncus cyperoides floridus, "Juncus," saith he, "for that his stalke is like the rush; cyperoides, because his leaves do resemble Cyperus; floridus, because it hath on the top of every rushie stalke a fine umbel or tuft of small flowers in fashion of the Lilic of Alexandria." Gerarde, p. 27.

Butomus umbellatus, L. 
Frowk-, or Flook-wont, from its being supposed to give sheep the discase of the liver, in which parasites rescmbling the flook-or flounder-fish are found,

Hydrocotylc vulgaris, L.

Fudellix, probably from Du. flureelen, downy, velvety, Fr. velvote, and not, as Parkinson states, a Welsh word, the several species of Veronica, L.

"Female, of Gerarde, Hill, Curtis, and others, from its soft velvety leaves,

Linaria spuria, L.

Flybane, from its being used mixed with milk to kill flies,

Agaricus muscarius, L.

Fly Honeysuckre, from confusion with an Apocynum that eatches flies by the proboscis under its anthers, the A. androsamifolium, L., and whose flowers are somewhat similar, the upright honeysuckle,

Lonicera Xylosteum, L.

Fly Orchis, from the rescmblance of its flower to a $\mathrm{fly}$, Ophrys muscifera, Hud.

FolEFoOT, from the shape of its leaf,

Asarum europæum, L. and Tussilago Farfara, L.

Fool's Parslex, from its being a poisonous plant, which only fools could mistake for parsley,

Ethusa Cynapium, L.

Forebitten More, bitten-off root, sec Devil's-Bit, more or mor having formerly had the sense of "root," as it has still in the Western eountics,

Scabiosa succisa, I.

FORGET-ME-NOT, a name that for about fifty years has been assigned to a well known blue flower, a Myosotis, but which for more than 200 ycars had in this country, France, and the Netherlands, been given to a very different plant, the ground-pine, Ajuga Chamæpitys, on account, as was said, of the nauseous taste that it leaves in the moutl. It is to this plant exclusively that we find it assigned by Isyte, Lobel, Gerarde, Parkinson, and all our herbalists from the middle of the fifteenth eentury, and by all other 
botanieal authors who mention the plant, inclusive of Gray in his Natural Arrangement published in 1821, until it was transferred with the pretty story of a drowned lover to that whieh now bears it. This had always been called in England Mouse-ear Seorpion-grass. In Germany, Fuchs in his Hist. Plant. (Basil, 1542), gives the name Vergiss nit mein to the Teuerium Botrys, L. under the Lat. synonym of Chamædrys vera fomina. His exeellent plate at p. 870 leaves no doubt as to the species he meant. In Denmark a eorresponding name, Forglemm mig icke, was given to the Veroniea ehamadrys. At the same time it would seem that in some parts of Germany the Myosotis palustris was known as the Echium amoris, and Vergiss mein nicht, as at the present day; and in Swedish the Eehium aquaticum, the same plant, was ealled förgät mig icke. Some idea of the eonfusion will be seen in Mentzel's Index Nominum Plantarum, Berlin, 1682. Cordus on Dioseorides, in 1549, and Lonieerus assign it to Gnaphalium leontopodium, L. while the Ortus Sanitatis (Ed. 1536, ch. 199), and Macer de virtutibus herbarum (Ed. 1559), like the Danish Herbalists, give it to the Veroniea Chamædrys, L. This latter seems to be the plant to which the name rightfully helongs, and to which it was given in referenee to the blossoms falling off and flying away. See Speedwell. From this plant it will have been transferred to the ground-pine through a eonfusion in respect to which species should properly be ealled Chamadrys, and as both these rery different plants were taken for the Chamædrys of Pliny, the popular name of the one passed to the other. Tro cireumstanees about it are eurious; first, how the name could be transferred from the ground-pine to the seorpiongrass without the ehange being notieed by a single author of all our floras, general and loeal; and seeondly, how easily a good story is got up, and widely spread about the world, to mateh a name. The blossoms fall from a $\mathrm{Te}$ - 
ronica, and it is called "Speedwell!" and " Forget-me-not." The name passes to a plant of nauseous taste, the groundpine, and Dalechamp explains it as expressive of this disagreeable quality. It attaches itself to a river-side plant, and the story books are ready with a legend. We learn from Mills's History of Chivalry that a flower that bore the name of "Soveigne vous de moy," was in the fourteenth century woven into collars, and worn by knights, and that one of these was the subject of a famous joust fought in 14.65 between the two most accomplished knights of England and France. What the flower was, that was so called, it would be only possible to ascertain by inspection of one of these collars. The German name Ehrenpreis, prize of honour, which lias always been given to the speedwell, almost proves that this was the one. There is certainly no ground for assuming that it was the same as our present "Forget-me-not." The story of this latter, in connexion with the two lovers, will be found in Mills's work, vol. i. p. 314, and it now bears a name corresponding to our own in nearly every European languagc: as Fr. Ne m'oubliez pas, G. Vergiss mein nicht, Da. Kicrminde, Sw. Förgat mig icke, etc., and is worked into numberless rings and other ornaments.

Myosotis palustris, I.

Four-LEaved grass, a plant with four leaves only, the Herb Trulove,

Paris quadrifolia, L.

Foxglove, a name that is so inappropriate to the plant, that many explanations of it have been attempted, by which it might appear to mean something different from the glove of a fox. Its Norwegian names, Rev-bielde, foxbcll, and Reveleika, fox music, are the only foreign ones that allude to that animal ; and they explain our own, as having been in the first place foxes-glew, or music, A.S. gliew, in reference to a favourite instrument of earlier times, a ring of bells hung on an arched support, a tintinnabulum, which this plant, with its hanging bell-shaped 
flowers, so exactly represents. Its present latin name, Digitalis, was given to it by Fuclis with the remark that up to that timc, 3542, there was none for it in Greek or Latin.

D. purpurea, L.

For-tall-Grass, from the shape of the spike, Gr. of

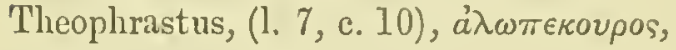

Alopecurus pratensis, L.

"Slender-, Alopccurus agrestis, L.

Franborse, a French corruption of Du. Erambezie, bramble-berry, the raspberry, Rubus idæus, L.

Franke, from "the property it hath to fatten cattle," as Lyte tells us (chap. 35); franke meaning a styc or stall, in which cattle were shut up to be fattened;

Spergula arvensis, L.

French bean, a foreign bean, French being used to express what in German would be called wälsch, anything from an outlandish country, Phaseolus vulgaris, L.

Frunch cowstip, Primula Auricula, L.

French Grass, sainfoin, L. fanum Burgundiacum,

Onobrychis sativa, $\mathrm{L}$.

French Honeysuckle, from the resemblance of its flowers to large heads of honeysuckle clover, Hedysarum coronarium, L.

French Lavender,

French Nut, the walnut, Lavandula Stoechas, L. Juglans regia, L.

French Sorreu, the wood-sorrel, Oxalis acetosella, L.

French Sparrow-grass, the name under which are sold in the Bath market to be eaten as asparagus, the sprouts of the spiked Star of Bethlehem,

Ornithogalum pyrenaicum, $\mathrm{L}$.

French Wheat, the buckwheat,

Polygonum Fagopyrum, L.

Frenci WrLLow, from its leaves somerhat resembling those of the willow,

Epilobium angustifolium, L. 
Fresil-Water Soldier, from its sword-shaped leaves, Stratiotes aloides, L.

Friar's Cap, from its upper sepals resembling a friar's cowl, the wolfsbane,

Aeonitum Napellus, L. " CROWN,

Carduus eriophorus, $\mathrm{L}$.

Fritrilakr, M.Lat. firtillaria, se. tabula, a cheekerboard, from fritillus, a dicebox, on aecount of its eheekered petals,

F. Meleagris, L.

FroG-BIT, L. morsus rance, from an idea that frogs ate it, Hydrocharis Morsus ranæ, L.

Frog-Foot, a name that in the Stoekholm Med. M.S. 1. 783 , is assigned to the vervain, the leaf of whieh, in its general outline, somewhat resembles the foot of this animal :

Frossis fot men call it,

For his levys are like the frossys fet.

Verbena offieinalis, L.

In modern works, for reasons unknown, it is transferred to the duekmeat, Lemnil, $\mathrm{L}$.

Frog-grass, from its growing in mire,

Salicornia herbaeea, L.

Frog's Leettuce, Potamogreton densus, L. Frost-BLite, a blite whitened as by hoar-frost,

Chenopodium album, L.

Fulder's herb, L. herba fullonum, from its taking out stains from cloth, a purpose for whieh it is said by Tragus, e. 131, to have been used by the monks,

Saponaria officinalis, L.

Fulrer's thistle, the teasel, Dipsacus fullonum, L. Funtory, in Shalspeare Fumiter, Fr. fume-terre, L. fumus lerre, earth-smolie, from the belief that it was proluced without seed from vapours rising from the earth. The words of Platearius, a great authority in lis day, are: "Dieitur fumus terrce, quod generatur a quadam fumositate grossa, a terra resoluta, et eirea superficiem terræ adhe- 
rente." Sce also the Ortus Sanitatis, Maycnce, 1485, ch. 176, and the Grete Herball, cap. clxxi. And this cxtraordinary account of it is given not only by the ignorant authors of the Ortus Sanitatis and the Grcte Herball, and the writers in the dark ages from whom they copied, lout is repeated by Dodoens, and other learned men, his cotemporaries. Pliny merely says, (l. xxv. c. 13), that it took its name from causing the eyes to water when applied to them, as smoke does : "Claritatem facit inunctis oculis delachry-

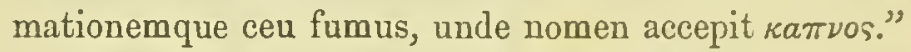

Fumaria officinalis, L.

Furze, sometimes spelt Furres, A.S. fyrs, a name of obscure derivation, as are those of so many of our commonest plants; apparently from fir, these bushes being, like the coniferous trees, a common firewood or fuel; but perhaps from $\mathrm{Fr}$. forest, as though that word meant a place of firs, as hyrst, carst, hulst, gorst, etc., the places or thickets of erica, carices, ulex and gorra, from M. Lat. words in cetum;

Ulex europæus, L.

" NeEUle-, from its finely pointed slender spines, Genista anglica, Hud.

Fuss-BaLLs, Fr. vesse, Lycoperdon, L.

Gadrise, and Gaitre, see Gatter.

Gale, or Sweet Gale, in Turner's herbal Gall, and in Somersetshire, he tells us, Gove and Golle, in Pr. Pm. gawl, gavl, or gawyl, A.S. and Du. gagel, corruptions apparently of galangale, a name that it may have acquired from its fragrance while burning, and which, through its intense bitterness, has become confounded with gall,

Myrica Gale, L.

Galangale, It. and Sp. galanga, O. Sp. garingal, G. galgant, from Pers. chalan, or Arab. Khalanjān, a word supposed to be a corruption from Chin. liang-kiang, mild ginger, the name under which that spice was introduced 
from China, and now transferred to a marsh plant, the roots of which are valued for their aromatic quality,

Cyperus longus, $\mathrm{L}$.

Gallow-Grass, Ger. p. 572, a cant name for hemp, as furnishing lalters for the gibbet, Cannabis sativa, L.

GANG-FLower, flos ambarvalis, the milkwort, from its blossoming in Gang-week, A.S. gang-dagum, three days before the Ascension, when processions were made in imitation of the ancient Ambarvalia, to perambulate the parishes with the Holy Cross and Litanies, to mark their boundaries, and invoke the blessing of God upon the crops; on which occasions, says Bishop Kennett, "the maids made garlands of it and used them in those solemn processions." So also Gerarde, p. 450. It was for the same reason called Cross-, Rogation-, and Processionflower.

Polygala vulgaris, L.

Garavarce, the chick-pea, or gram, Sp. garavanzo, Bask. garau, corn, and anzua, dry (Diez),

Cicer arietinum, $\mathrm{L}$.

GARLick, A.S. gar, a spear, and leac, plant, from its tapering acute leaves; or from the nutritive and stimulant qualities ascribed to it by the ancient northern poets as being the "war plant,"

Allium sativum, L.

GARLICK-WORT, from its smell,

Erysimum Alliaria, L.

GARNET-BERRY, the red currant, from its rich red colour and transparency,

Ribes rubrum, L.

Gatter, Gatten, Gadrise, or Gatteridge, names of several hedgerows, trees and shrubs, as the spindle, the cornel, and wild Guelder-rose, Evonymus europæus,

Cornus sanguinea, and Viburnum Opulus, L. derived, respectively, Gatter, in Chaucer Gaitre, from A.S. gad, a goad, and ter, i.e. treow, tree; Gatten, from gad, and tan, twig; Gadrise, from gad and hris, a rod, Da. and Du. riis, a shrub, and Gatteridge, $\mathrm{Fr}$. verge sanguine, from 
gaitre rouge, in referenee to the red colour of the twigs and antumnal foliage of the spindle and cornel trce. Gal is still used in our Western counties for a picked stick in the term spar-gad, a stick pointed at both ends to spar or fasten down thatel.

GaZLES, in Sussex and Kent, the black currant, apparently eorrupted from Fr. groseilles,

Ribes nigrum, L.

Gean, the wild cherry, Fr. guisne, Pol. wisn, Boh. wissne, in European Turkey wischna, Wal. visini, ML.Gr. Bıøıos, the two last words being identical with the Slavonian, i.e. the Polish and Bohemian, as far as they ean be written with Greek letters. We may eonelnde from this identity, and from the great quantity of pipe-sticks of it exported every year from Turkey, that the name originated in that eountry. The Dalmatians will have Italianized wischna into viscina, and under this name it will have been eonveyed to Italy, and thenee into Franee, where by the usual proeess of changing $v$ or $w$ to $g u$, and dropping the sound of $s$ and $s c$ before $n$, riscina becomcs guisne, and erossed into England as gean. But the Italians will have regarded viscina as a diminutive in ina from viscia, and have replaeed it, from some motive of euphony, by risciola, its present name, as they have formed biscuola from biscia, pescinolo from pesce, etc., and hence the German weicksel, which will not only represent the same tree, but the same word, as our Gean. It is to be observed that the "Bird eherry" is not this species, although this is the one ealled so by botanists in Latin systematic works. Prunus arium, L.

Gentins, from some Illyrian king named Gentius, Gentian:ı, L.

Gersnium, Gr. yepavtov, from yepavos, erane, the eranesbill, from the shape of the seed ressel, a genus that once included the Pelargonia, whieh in popular language are still ealled so, $\quad$ G. molle, pratense, ete. 
Gerard, sec Herb Gerard.

German Madwort, Du. meed, madder, and wort, root, so called from the red dye yielded by its roots, and its being used in Germany, Aspcrugo procumbens, L.

Germander, Fr. gamandrée, from L. chamcedrys, by insertion of an $n$ before $d$ for euphony, Gr. $\chi a \mu a \iota$, ground, and $\delta \rho v s$, oak, so named from the fancied likeness of its leaves to those of an oak, a name usually given to the

Teucrium Chamædrys, L.

Water-, Teucrium Scordium, L.
"WooD-,
Teucrium Scorodonia, L.

Germander Chickweed, the male Chamadrys of the herbalists,

Veronica agrestis, L.

Gill, Gill-go-By-Ground, Gill-creep-By-The-ground, GiLL-RLN-BITH-Ground, the ground-ivy, from its name Gill, that was given to it from its being used in fermenting beer, $\mathrm{Fr}$. guiller, a word still retained in the eastern counties, getting mixed up with another mcaning of Gill, that of a young woman, a girl; the go-by-ground, etc. referring to the crceping habit of the plant. Sec HAYMAIDS.

Nepeta Glechoma, Benth.

Gillirlower, formerly spelt gyllofer and gilofre, with the o long, from Fr. giroflée, It. garofalo, in Douglas's Virgil jereflouris, words formed from M. Lat. garoffolum, gariofilum, or, as in Albert Magn. (1. vi. c. 22), gariofilus,

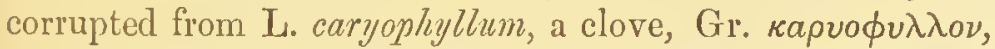
and referring to the spicy odour of the flower, which seems to have been used in flavouring wines to replace the more costly clove of India. The name was originally given in Italy to plants of the Pink tribe, especially the carnation, but has in England becn transferred of late year's to several cruciferous plants. That of Chaucer and Spenser and Shakspeare was, as in Italy, Dianthus Caryophyllus, L. that of later writers and gardeners,

Matthiola and Cheiranthus, L. 
Mueh of the eonfusion in the names of plants has arisen from the vague use of the French terms Giroflée, Oeillet, and Violette, which were, all three of them, applied to flowers of the Pink tribe, but subsequently extended, and finally restricted in English to very different plants. Giroflée has become Gilliflower, and passed over to the Cruciferæ, Oeillet been restricted to the Sweet Williams, and Tiolette been appropriated to one of the numerous claimants of its name, the genus to which the pansy belongs.

" Clove-, Dianthus Caryophyllus, L.
" Marsh-, the ragged-Robin,

Lyehnis flos cueuli, L.

"Queen's-, or Rogue's- or Winter-, the Dame's violet,

"STOcK-, Hesperis matronalis, I.

"WALI-, of old books, Ch
"WATER-, of Lyte's Herball,

Matthiola incana, L.

Cheiranthus Cheiri, L.

Hottonia palustris, L.

Gilliflower-grass, in Aubrey's Wilts, p. 49. See Carnation-grass.

Gipsey-wort, so called, says Lyte, " bycause the rogues and runagates which call themselves Egyptians, do colour themselves black with this herbe,"

Lycopus europæus, L.

GrTH, L. gith, an ancient name of the Nigella now applied to the corn-cockle, Agrostemma Githago, L.

Gladdon, Graden, Glader, Gladirys, names of the stinking iris usually derived from L. gladiolus, a small sword, in allusion to its sword-shaped leaves, but whieh have more probably arisen from confusion of its Dutch name lisch, with O.Freneh leesche, gladness. If from gladiolus, they will be plurals of glad; but as in herbal nomenelature the plant is ealled spatula, a tool used in 
smoothing, they may be related to Du. glad, smooth.

Iris fœtidissima, L.

GIAdiole, L. gladiolus, a small sword,

„W WateR-, the flowering rush,

Butomus umbellatus, L.

GLASSWORT, from furnishing ashes for glass-making,

Salieornia herbacen, L.

, Prickly-,

Salsola Kali, L.

Glastonbury Thorr, a variety of whitethorn, so ealled from the place where it was first enltivated.

GLobe rlower, from its globular form,

Trollius europæus, L.

Globe Thistle, from its globular infloreseenee,

Eehinops, L.

GOAT'S BEARD, from its long eoarse pappus, a translation

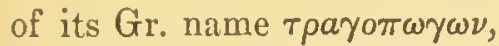

Tragopogon pratensis, L.

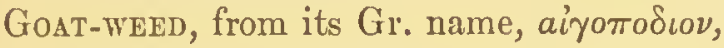
Egopodium Podagraria, L.

Gold-APPLES, Fr. pommes d'or, from their colour before maturity, tomatoes,

Solanum Lyeopersieum, L.

Gold of Plessure, a name which Gerarde and Parkinson attempt to explain by telling us that "the poore peasant doth use the oile in banquets, and the rich in their lampes." This seems to be a way of getting over a diffieulty by foreing a sense upon it. We learn from Gerarde that an oil was imported from Spain as "Oleo de Alegria," this latter word Alegria, being the name of anotler" oilplant, a sesamum, and it would seem that this "Oleo de Alegria" has beeome eorrupted to "Oro de alegria," gold of pleasure, and applied to a very different species, the souree of a spurious oil, passed off upon the publie for the Spanish. Whether Alegria was applied to the sesamum in the sense of "pleasure," or is an Arabie word beginning with al, it is irrelevant to inquire. Camelina sativa, L. 
Gold-curs, from O.E. cop, a liead, a button, or stud, and like King-eup, Gilt-cup, and 13utter-cup, representing the Fr. bouton d'or, the batehelor's l Jutton, Ranunculus, I.

GoLD-KNOBS, -KNAPPES, ol-KXopPES, A.S. cnep, a luttrin, Du. knoop. See Gold-cup.

GoLDF, in our old poets the marigold, supposed from its yellow flowers, to have been the $\chi \rho \nu \sigma a \nu \theta \epsilon \mu o \nu$, or gold flower of the Greelss, Calcudula officinalis, $\mathrm{L}$.

Gouden-Chais, from its long racemes of yellow flowers, Du. goude keten, in Sweden more tastefully called guldregn, golden rain,

Cytisus Laburnum, L.

GoLDEN-ROD, Lat. virga aurea, from its tall straight stalk of yellow flowers,

Solidago Virga aurea, L.

Golden SanpHIRE, from its thick samphire-like stems, and its golden flowers,

Inula crithmoides, L.

Golden Saximrage, from its yellow flowers,

Chrysosplenium, L.

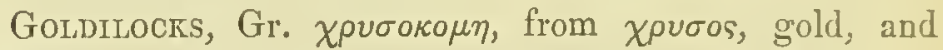
ко $\mu \eta$, hair, also

Chrysocoma Linosyris, L. Ranuneulus Auricomus, L.

Goldins, or Goldings, Du. gulden, golden, a florin, from the yellow eolour and flat round shape of its flowers, the sonrce of the numerous Scoteh names applied to the marigold, the marsh marigold, and other yellow flowers, such as Gowlan, Gowan, Gool, Goule, etc. See below Goous. By Goldin is usually meant the corn-marigold,

Chrysanthemum segetum, L.

Good Henry, or Good King Harry, the allgood, G. guter Heimich, Du. goeden Henrik, an obscure name, which Dodoens tells us (p.65l) was given to the plant to distinguish it from another, a poisonous one, called Malus Henricus; but why they were either of them called Henricus, he does not say. The Grimms in their Wörterbuch explain it as having reference to elves and liobolds which were called "Heinz" or "Heinrich," and as indicating supcr- 
natural powers in the plants. Cotgrave gives the name Bon Ilenry to the Roman sorrel, Rumex seutatus, L. as well as to the allgood, the plant to which it is usually assigned. Cordus on Dioseorides, Frankf. 1549, calls it "Weyss heyderich, vel ut alii volunt, Giit heynrich." It lias nothing to do with our Harry the Sth, and his sore legs, to which some have thought that it referred.

Chenopodium Bonus Henrieus, $L$.

Gools, Gules, Gowles, Gulldes, Goulans, Gowans, and Golds. See under Goldins.

Calendula offieinalis, Caltha palustris, and Chrysanthemum segetum, L.

Goose and Goslings, or Gandergosses, from the flowers being shaped like little goslings,

Orehis Morio, and bifolia, L.

Gooseberry, from the Fl. kroes or kmys bezie, Siv. krustuir, a word that bears the two meanings of "cross-" and "frizzle-berry," but was given to this fruit with the first meaning in referenee to its triple spine which not unfrequently presents the form of a eross. This equivoeal word was misunderstood and taken in its other sense of "frizzle-berry," and translated into German and herbalist Latin kräisel-beere and uva crispa. Matthioli (ed. Camerarii, li56) gives its German synonym eorreetly, as kreuzbeer. Lobel also (Krydtb. pt. ii. 1). 239) gives it as W'lem. krocsbesien, G. kruzbeer. The Fr. groseille, and Span. grosella are eorruptions of $\mathrm{G}$. liraïscl.

Ribes Grossularia, L.

Gooskbill, or Gooseshare, elivers, from the sharp serrated leaves being like the rough-edged mandibles of a groose,

Galium Aparine, L.

GoosEcorN, from its growth on eommons where geese are commonly reared, and the grain-like appearanee of the capsules,

$J$ uneus squarrosus, $L$. 
Goose-Foot, from the shape of its leaf,

Chenopodium, Is.

Goose-Grass, in Ray by mistake Goose-Grease, Pr. Pm. gosys gres, elivers, from a belief that goslings feed on it, (R. Turner, Bot. p. 71), and that "geese help their diseases with it," (Lupton, No. 60).

Galium Aparine, I.

Goose-herrifre of W. Coles's Adam in Eden; A.S. gas, a goose, and hegerife, hedge-reeve, from its attaehing itself to geese, while they pass through a hedge. The occurrenee of the name in this work of W. Coles is singular as an instanee of the retention into the seventeenth century of an Anglo-Saxon word no longer understood. The name is still retained in some counties as hariff. The Gooshareth, Goshareth, and Gooseshareth of W. Turner's Herball seem to be eorruptions of Goosehariff with a change of $f$ to th that is not uneommon in provineialisms, as for instance in the ease of fape and thape. Galium Aparine, L.

Goose-Tansy, a plant with tansy-like leaves, whieh Ray says is called so "beeause eaten by geese;" but perhaps like erow's garliek, swine's eress, and dog's mereury, the name may imply merely a tansy for a goose, a spurious tansy.

Potentilla anserina, $\mathrm{L}$.

Goose-tongue, from its finely serrated leaves,

Aehillæa Ptarmiea, L.

Gonse, A.S. gorst, Wel. gores or gorest, a waste, M. Lat. gorassi or gorra, brushwoud, used in Stat. Nontis reg. p. 236: "salicum, gorrarum et gorassorum non portantium fruetus comestibiles." Ulex europæus, L.

GoRY-DEW, from its resemblanee to blood drops,

Palmella eruenta, Agh.

Go-TO-BED-AT-NOON, from its early elosing, the gont's beard,

Tragopogon pratensis, L.

Gound, Fr. gourde, from gougourde, L. cucurbita,

C. Pepo, L.

Gou't Ivy, M.Lat. Iva arthritica, from being, as Parkin- 
son says, "powerful and effectual in all the pains and diseases of the joints, as gouts, eramps, palsies, sciatiea, and aches," the ground pine,

Ajuga Chamæpitys, L.

Gour-WEed, ol Gour-wort, from its supposed virtues in gout eases, Agopodium Podagraria, L.

Gowas, a north country word, usually derived from Gael. gugan, a bud, a flower, but clearly a colruption of govlan, the Seoteh form of gulden, as we see in the names of the troll-flower, whieh is called indifferently Luckengowan, -gollond, or -gowlan, and Witeh's gowan. Cf. gawn, a gallon measure, a milk-pail, in The Derby Ram. (Halliwell). In the glossaries it is usually explained as meaning merely "the daisy;" but it appears in diflerent parts of Seotland to be applied to the various luttercups, and the marslı-marigold, the dandelion, the hawkweeds, the corn-marigold, the globe flower, and indeed to almost any that is yellow. In the northern eounties of England, according to Brockett, it is a yellow flower common in moist meadows. W. Turner in his Libellus says that Golland is a name given to the king-eup or erow-foot.

Gowk-MEAT, from its blossoming when the gowk or cuckoo eomes, the wood-sorrel,

Oxalis Aeetosella, L.

Gray, an Eastern name, the ehiek pea,

Cieer arietinum, L.

Grape Hyacinth, or Grape flotrer, from its small round purplish flowers sitting in elusters on the stalk, like grapes,

Museari racemosum, Mill.

Grass, A.S. and Fris. gars, in nearly all other Germanic dialeets gras, and radically conneeted witl $\mathrm{L}$. gramen. By the old herbalists grass is used in the sense of a herb generally, and often spelt gres, which has led to its being misspelt grease in several names. By botanists the term is eonfined to the order

Gramineæ.

See under their specific names 
Grass, Arrow-

, BaLlocK-

"Bent-

„Brome-

"Canary-

"Carnation-

, Cat'S-Tail-

, Cock's-Foor-

„Cord-

„Cotton-

„COuch-

, Crab-

„ Cuckoo-

„Dog-

, Dog's-TAIL-

, Dog's-тооти-

„ Dоов-

, Feather-

" Fescue-

, Fiorin-

, Frnger-

" FIVE-FINGER-

, ElLOTE-

„ Foxtall-

" French-

"Gallow-

, GRIP-

, HaIr-

"Hard-

", HaRES-TAII,

"Hassock-

, KNOT-

, LOB-

", LYYSE-

"MaT-

"Meadow-
Grass, Mousf-'taif-

"Nit-

"OAT-

„ Orchard-

" Pexiy-

„ Plepper-

"Pigeny's.

" Puddixg-

, QuAKE-

"Quitch-

"RAY-

"REED-

„ RiB-

„Ribbon-

„ Rie-or Rye-

"Scorpiox-

"Scurvy-

"SEA-

"Shave-

„Shelly-

, Shere-

"ShorE-

, Sparrow-

Sprixg-

Spert-

SquirRed-Tate-

STaNder-

Star-

Swine-

Тгмотну-

TOAD.

Tussac-

Tropexiy

VERNAL-

VIPER'S-

WHITLOW- 
Griss, MeLick-

Mrtelet-

Mloon-
Grdss, Wire-Bent-

"WoOd-

Grass of Parnassus, a plant described by the Greek writers as growing on that mountain,

Parnassia palustris, L.

Griss-POLEY, from its being considered by Cordus as a pulegium or poley, and having grass-like leaves,

$$
\text { Lythrum hyssopifolium, I. }
$$

Grass-vetch, a vetel with grass-like leaves,

Lathyrus Nissolia, L.

Grass-wrack, a wrack with long linear grass-like leaves, Zostera marina, I.

Greeds, A.S. greed, translated in Alfric's glossary "ulva," a name of some water plant, now applied to the jondweed tribe,

Potamogeton, I.

Greek Valemian, a plant mistaken for the Phu or Talerian of the Greek writers, Polcmonium cæruleum, L.

Grefesauce, from its culinary use, Rumex acetosa, L.

Grewi-Wled, or Grennixg-Weed, from its use to dye yreen,

Genista tinctoria, L.

Greess or Granes, in Lyte's Herball Grayves, Du. Einden-gruen, duck's herb,

Lemna, I.

GrigG, heath, Wel. grigg, related to W. grwg and grig, a rumbling noise. See Branвze. Calluna vulgaris, Sal.

Grimm the collier, the name of a humorous comedy popular in Q. Elizabeth's reign, called "Grimm the collier" of Croydon," and given to the plant from its black smutty involucre,

Hieraeium aurantiacum, L.

Grip-Gr.ss, from its gripping or scizing with its hooked prickles whitever comes in its way, Galium sparine, I.

Gromerl, Grumel, or Gromweld, or Giray myie, as Turner says it should be written, from Grannm solis and Hilium solis together. "That is al one," says the Grete Herball, "granum solis and milium solis." The apothe- 
carics compromised the matter by combining them, as in the case of Asarabacea.

Ground Funze, Lithospermum officinale, Is.

Growndeele, G. grundheil, Fr. herbe aux ladres, so called from its having curcd a king of France of a leprosy from which he had been suffering eight years, a disease called in German grind. Brunschwygk tells us (b. ii. ch. 5), that a shcpherd had seen a stag, whose hind quarter was covered with a scabby eruption from the bite of a wolf, cure itself by eating of this plant and rolling itself upon it and that thereupon he recommended it to his king.

\section{Veronica officinalis, L.}

Ground Nut, or Gruxnut, from its tuber having the flavour of a nut,

Bunium flexuosum, $\mathrm{W}$.

Ground Iry, L. hedera terrestris, a name which at present is restricted to the Glcchoma, but in the Stockholm Med. M.S. 1. 861 (Archæol. v. xxx. p. 370) is given to the periwinkle:

Parvente is an erbe grene of colour;

In tyme of may he beryth blo flour.

His stalkys are so feynt and feye,

That never more groweth he heje.

On the grownde he rennyth and growe,

As doth the erbe that hyth tunhowe.

The lef is thicke, schinende, and styf,

As is the grene ivy leuf;

Unche brod and nerhand rownde;

Men call it the ivy of the grownde.

From the periwinkle the name has been transferred to a labiate plant,

Nepeta Glechoma, Benth.

Ground Pine, Gr. $\chi a \mu a \iota \pi \iota t u s$ from $\chi a \mu a \iota$, ground-, anl $\pi \iota \tau \cup s$, pine, so called from its terebinthinate odour, thc forget-me-not of all English berbalists till the beginning of this century,

Ajuga Chamæpitys, Sm.

Groundsel, in a MS. of the filteenth century GrondeswrLE, A.S. grundswelge, ground glutton, from grund, 
urround, and swelgan, swallow, still called in Scotland and on the Lastern Border grindy-swallow,

Senecio vulgaris, I.

Guelder Rose, from its lose-like balls of white flowers, a variety of the water-elder introduced from Gueldres,

Viburnum Opulus, L.

Guernsky-LILY, from its occurrence as a naturalized plant on that island,

Nerine sarniensis, W.

GoLF-WEed, from its floating on the gulf-streim, Sargassum baceiferum, B.

Guned Hex, from its Latin name, Meleagris, given to it from its petals being spotted like this bird, a native of the Guinea coast of Africa,

Fritillaria Meleagris, L.

Hag-berry, see Heg-berry.

Hag-TAPer, G, unholdenkerze. Gerarde tells us that "Apuleius reporteth a tale of Ulysses, Mercurie, and the inchauntresse Circe using these herbes in their incantation and witcherafts." See Higtaper.

Verbascum Thapsus, L.

HAIR-BELL, an unauthorized but very plausible correction of the more usual spelling, Ilarebell, a name descriptive of the bell-shaped flowers and delicate stalks of the plant,

Campanula rotundifolia, L.

HajR-grass, an imitation of its Latin name, Aira, L.

Halielujar, the wood-sorrel, from its blossoming between Easter and Whitsuntide, the season at which the Psalms were sung which end with that word; those, namely, from the 113th to the 117th inclusive. It bears the same name in German, French, Italian, and Spanish for the same reason. There is a statement in some popular works, that it was upon the ternate leaf of this plant that St. Patrick proved to his rude audience the possibility of a Trinity in Unity, and that it was from this called /lalle- 
lujah; au assertion for which there is no ground whatever. Oxalis Acetosella, I.

Hatm or Haulm, A.S. healm, straw, Du. helm and halm,

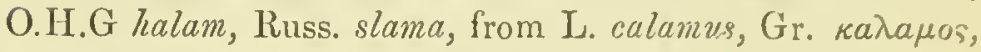
Skr. Kalama, its root hal, coneeal, eover, from its early and general use as thateh, Psamma arenaria, PB.

HARD-BEAM, from the laardness of its wood, the hornbeam, Carpinus Betulus, I.

Hard-grass, Rottbocllia ineurvata, $\mathrm{L}$.

HaRD-HAY, G. hartheu, or, as in old writers, harthan, from its liard stalks,

Hyperieum quadrangulum, L.

Hand-HFads, from the resemblanee of its knotty involucre to a weapon ealled a loggerhead, a ball of iron on a long handle,

Centaurea nigra, L.

HARDOCK, a word that occurs in the oldest cditions of Shakspeare, in K. Lear (Act iv. sc. 4), but in later ones is wrongly replaeed with Harlock. It seems to mean the burdoek, and to be so ealled from its involucres getting entangled in wool and flax, and forming the lumps ealled in old works hardes or herdes, whieh is explained by Batman on Bartholomew (c. 160), as "what is called in Latin strupa, and is the eleusing (i.e. the refuse) of hempe and flexe," the equivalcnt of Fr. Zourre from L. burra; as is evident from a passage in the Romaunt of the Rose, where Chaueer translates the phrase (1. 1233),

"Elle ne fut de bourras"

by

"That not of hempen herdes was."

Hardock will therefore be exaetly equiralent to Burdock. Arctium Lappa, L.

HARE-BELL, a name to whieh there is no corresponding onc in other lauguages, in England assigned by most writers to Campanula rotundifolia, L. 
in Scotland, and in some English works, including Parkinson's Paradisc, to the bluebell, Scilla nutans, Sm.

Hare's-ear, L. auricula leporis, from the shape of the leaves, Bupleurum rotundifolium, L. and also Erysimum orientale, L.

НАRE'S-Fоот, Fr. pied äe lievre, G. hasenfuss, from its soft downy heads of flowers,

Trifolium arvense, L.

Hare's Lettuce, from its name in Apuleius, Lactuca leporina, called so, says he, because "when the hare is fainting with heat, she recruits her strength with it:" or as Anthony Askham says, "yf a hare eate of this herbe in somer, when he is mad, he shal be hole." Topscll also tells us in his Natural History, p. 209, that, "when Hares are overcome with heat, they eat of an herb called Lactuca leporina, that is the Hares-lcttice, Hares-house, Harespalace; and there is no disease in this beast, the cure whereof she does not seek for in this herb." This hare's panacea is the sow-thistle, Sonchus oleraceus, $\mathrm{L}$.

HaRE'S PalaCE, Fr. palais de lièrre, L. palatium leporis, G. hasen-hans, the same as the hare's lettuce, and so called from a superstition that the hare derives shelter and courage from it; as we learn from the Ortus Sanitatis, ch. 334: "Dises kraut heissend ctlich hasenstrauch, ctlich hasenhauss; dann so der hase darunder ist, so furchtet er sich nit, und duncket sich gantz sicher, wann dises kraut hat macht über die melancoley. Nun ist kein thiere als gar ein mclancholicus als der hase." See Hare's Lettuce.

\section{Sonchus oleraceus, L.}

HARE'S-TaIL, from its soft flower-heads,

Lagurus ovatus, L.

Hare's-Tall-rush, a translation of Lat. Juncus cum cauda leporina, its name in Bauhin (Th. Bot. ii. 514), and Plukenet (Alm. 201.), from its wiry rush-like stems, and the protrusion, after flowcring, of soft liypogynous 
bristles resembling a lare's tail,

Hare-thistle, sce Hare's-letituce.

Erioplıorum vagrinatum, I.

Harif, Heiriff, Haireve or Haritch, in Pr. Pin. hayryf, A.S. hegerife, from A.S. hege, hedgc, and reafin, which, significantly enough, means botli a tax-gatlever and a robber, so called, we may suppose, from its plucking wool from passing sliecp; originally the burdock, at present the goose-grass,

Galium A parine, L.

HarLock, as usually printed in K. Lear (A. iv. sc. 4), and in Drayton, Ecl. 4:

"The honeysuckle, the harlocke,

The lily, and the lady-smocke:"

is a word that does not occur in the herbals, and which the commentators have supposed to be a misprint for charlock. There can be little doubt that Hardock is the correct reading and that the plant meant is the one now called Burdock. See above Haredock. Arctium Lappa, L.

Harstrong, or Horestrong, Du. harstrang, G. harnstrange, strangury, from its supposed curative porrers in this complaint,

Peuccdanum officinale, $\mathrm{L}$.

Hart's Clover, the melilot, so called, says R. Turner (Bot. p. 199), " because deer delight to feed on it," Melilotus officinalis, L.

Hart's-hors, from its furcated leaves,

Plantago Coronopus, L.

Hart's-тhorn, Florio in v., the buckthorn, L. spina cervina, Rhamnus catharticus, L.

HART'S-TONGUE, from the shape of the frond, the Lingua cerina of the apothecaries,

Scolopendrium vulgare, Gärt.

Hartwort, so called, because, as Parkinson tells us, (Th. Bot. p. 908) : "Pliny saith that women use it before their delivery, to help them at that time, bcing taught by 
hindes that eatc it to speade their delivery, as Aristotle did declare it before."

Tordylium maximum, I.

HARVEST-BELLS, from its season of flowering,

Gentiana Pneumonanthe, I.

HASK-wonT, a plant used for the hask or inflamed trachea, being from its open throat-likc appearance supposed, on the doctrine of signatures, to cure throat diseases. Ilask in the $\mathrm{Pr}$. Pm. is set down as synonymous with harske, austere, $\mathrm{S} w$, and Du. harsk, a term applied to fruits. Turner writes it harrish, as "dates are good for the harrishnes or roughnes of the throte," or what we should at present call huskiness.

Campanula latifolia, L.

Hassocks, A.S. cassuc, rushes, sedges, and coarse grasscs. "In Norfolk coarse grass which grows in rank tufts on boggy ground is termed hassock." A. Way in Pr. Pm. in v. "Hassock." The use of this term for the thick matted foot-stools used in churches scems to be taken from the application in that county to such purpose of the natural tumps of a large sedge, the

Carex paniculata, Is.

Hather, see Heath.

HAver, wild oat, Du. haver, G. hater or hafer, O.II.G. haparo, O.N. hafia, Sw. hafie, Da. havre, Wal. hufar, a name that, according to Holmboe, once mcant corn generally, but was gradually restricted to the species most commonly used, the oat. J. Grimm (Gesch. d. D. Spr. i. 66,) supposes it to be related to L. caper, a he-goat, but Diez with more probability derives it from L. avena, with the usual prefix of an aspirate, and the change of $n$ to $r$.

\section{Avena sativa, etc., L.}

HAWK-BIT, or HAWK-WEED, from a notion entcrtained by the ancients that with this plant hawks were in the habit of clearing their eyesight. See Pliny (1. xx. c. 7).

Hicracium, L.

IIAWK'S BEARD, a name invented by S. H'. Gray, and 
issigned, without any reason given, to the genus

Crepis, L.

HAwK-NUT, a name of which lhay says, (Syn. p. 201,); "cujus nominis rationem non assequor," but undoubtedly" corrupted from Hog-nut, as it is eorreetly spelt in Jacob's Pl. Fav. p. 16.

Bunium flexuosum, With.

HAwTHorn, the thorn of haws, hays, or hedges, A.S. hagaðorn, hag-, or hegeðorn, G. hagedorn, Sw. hagtorn, an interesting word, as being a testimony to the use of hedges, and the appropriation of plots of land, from a very early period in the history of the Germanie raees. The term haw is incorreetly applied to the fruit of this tree in the expression "lips and haws," meaning, as it does, the fenee on whieh it grows, A.S. haga or hage, G. hage.

Cratægus Oxyacantha, L.

Haymaids, or Hedgemaids, the ground ivy, a plant common in hays and hedges, whieh has derived the second syllable of its name from having been used as a "gill" to ferment beer, Fr. guiller, a word that also bore the meaning of "girl," or "maid," as in the prorerb "Every Jaek must have his Gill." From the same equivocation have arisen other such names as "Lizzie, up the hedge!" ete. See GiLr. Nepeta Gleehoma, Benth.

HAZEL, A.S. hase or heresel, and, allowing for dialeet, the same word in all Germanie languages, the instrumental form of A.S. haes, a behest, an order, from A.S. hatan, O.H.G. haizan, G. heissen, give orders, a hazel stiek haring l,een used to enforee orders among slaves and eattle, and been the baton of the master. J. Grimm (Geseb. d. Deuts. Spr. p. 1016,) obscrves: "Der lirt zeigt uns das einfaehe vorbild des fürsten, des $\pi \circ \iota \mu \eta \nu \lambda a \omega \nu$, und sein haselstab crseheint wieder im zepter dcr liönige: "hafa $\mathrm{i}$ hendi heslikylfo' ['hold in hand a hazel staff'] ;" an expression that oceurs in Sæmund's Edda in the seeond lay of the Helgaquida, str. 20. The verb halsian, foretell, seems to 
le clerived from the use of the hazel rod for purposes of divination.

Corylus Avellana, L.

HAZEL-WonT, G. Thasel-wurz, from the similarity of its ealyx to the involuere of a nut, and not, as the books tell us, frnm its growing under hazel bushes, which it does not affeet more than other shrubs. Friseh eonsiders it to be eorrupted from L. asarum.

A. europæum, $I$.

Headache, or Head-Warke, from the effeet of its odour, the red field-poppy,

Papaver Rhœas, L.

HEART'S-EASE, a term meaning "a eordial," as in Sir Walter Seott's Antiquary, eh. xi.: "buy a dram to be eilding and elaise, and a supper and hearts-ease into the bargain," and given to eertain plants supposed to be cardiac; at present to the pansy only, but by Lyte, Bulleyn, and. W. Turner to the Wallflower equally. The most probable explanation of the name is this. There was a medieine "good," as Cotgrave tells us, "for the passions of the liearl,", and ealled garinfilé, from the eloves in it, L. caryophilla. The wall-flower also took its name from the elove, and was ealled girofiée, from the same Latin word. See Grlulfower. The eardiae qualities of the medieine were also extended to it, and the name of Hearts-ease ; and, as the wallflower and the pansy were both eomprehended among the Violets, that of Hearts-ease seems to have been transferred from the former to the species of the latter now called so. H. Brunsehwygk, in his eurious work "de arte distillandi," tells us of the wallflower: "Gel violen wasser kület ein wenig das herz: das gesehyeht uss ursaeh syner kreftigung und sterekung, ob es zu vil keltin het, so temperier es, ob es zu vil hytz het, so temperier es ouch darumb das es rlas herz erfiöwel." Tabernæmontanus also, (Kraüt. p. 6×9,) says of the wallflower: "Welehem menschen das IIerz zittert von Kälte, der soll sieh dieses gebranchen." The instanees are so numerous of the transference of an appropriate name to a plant to which it is 
quite unsuited, that we can find no diffeulty in assigninger this origin to the term Hearts-case as at present employed.

Viola tricolor, $\mathrm{l}$.

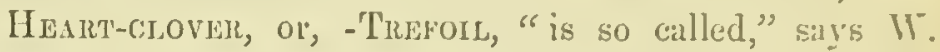
Coles, in his Art of Simpling, p. 89 , "not oncly because the leaf is triangular like the heart of a man, but also because each leafe contains the perfect icon of an lieart, and that in its proper eclour, viz., a flesh colour. It defendeth the heart against the noisome vapour of the spleen."

Mcdicago maeulata, Sibth.

Heath, Heather, or Hather, A.S. hað, G. heinle, O.N. heisi, Go. haipi, a word which primarily meant the country in whieh the heath grows, Skr. lishêtra, a field, Beng. liketa, and Skr. kshiti, land, from hshi, dwell. It is from the same root, kshi, that is derived Skr. kshamâ, ground, Prakr.

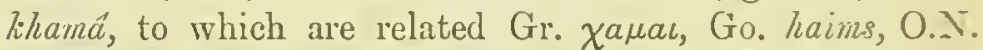
heimi, and our home. When the north of Europe was a forest, open land was naturally preferred for the site of dwellings, the heath was the only open land, and this acquired a name that had been used to designate a field, or homestead.

Eriea and Calluna.

„Irish-, or St. Dabeoc's-,

Menziesia polifolia, L. , SEA-, Frankenia pulverulenta, L.

HeAth-Cypress, from its resemblanee to a small eypress tree, and its growth upon heathy ground,

Lycopodium alpinum, L.

HEATH-PEd, from its pea-like eseulent tuber, and usually growing upon sandy heaths,

Lathyrus macrorhizus, Tim.

HeDGe BELLS, G. zann-glocke, a local, but expressirc name for the larger bindweed, Convolvulus sepium, $L$.

HEDGEHOG PARSLe, from its prickly burs,

Caucalis daucoides, $\mathrm{L}$.

HeDge Hrssor, a name transferred from a foreign 
speeies, a Grintiola, to a plant that does not often grow in hedges, the lesser sliulleap,

Seutellaria minor, L.

HEDGE-M.IIDS, see HaYMAIDS.

Hedge Mustard, Sisymbrium offieinale, L.

Hedge Nettle, or -dead netrle, Staehys sylvatiea, L.

Hedge Parsley, Cauealis Anthriscus, H.

Hedge Taper, see Hig-taper.

Hedge Thorn, see II ATthorn.

Hedae Vine, the Virgin's bower, Clematis Vitalba, L.

Heg-berry, Hedge-berry, Hag-, or Hack-berry, Sw. hiigg, N. and Da. hegebar, "a wood berry," from a wood being in the northern eounties ealled a hag, a word related to A.S. heye, hedge, the bird-cherry, Prunus Padus. L.

HELL-WEED, dodder, so ealled from the trouble and ruin it enuses in flax fields. 'Threlkeld observes, that "after it has fastened upon a plant, it quits the root, and like a eoshering parasite lives upon another's treneher, and first starves, and then kills its entertainer. Fer whieh reason irreligious elowns eurse it by the name of Hell-weed and Deril's-guts."

Cuseuta, L.

Helzebore, L. hellebornes, Gr. é $\lambda \lambda \epsilon \beta o p o s$, a word of doubtful origin, at present applied to eertain ranuneulaeeous plants, but not so in aneient works.

"BLACK-, the Christmas rose,

II. niger, Is.

" Fetid-, or Stinking-, H. fotidus, L.

" GREEN-,

II. viridis, $L$.

" Wixter-,

Eranthis hyemalis, $\mathrm{S}$.

Helizborine, from the resemblanee of its leaves to those of a veratrum ealled "white hellebore," Epipaetis, RB.

Hezm, see Hats. Psamma arenaria, PB.

Heimet-Fower, from the shape of the eorolla, the skulleap,

Seutellaria, L.

Heylock, or, as Gerarde spells it, Hourock, A.S. Kam or healm, straw or haulm, and lenc, plant, so ealled from the dry hollow stalks that remain after Howering; a name 
originally applied to any of the Umbelliferse, at present confined to two poisonous species,
"Common-,
Conium maculatum, $\mathrm{L}$.
"W WTER-,
Cicuta virosa, L.

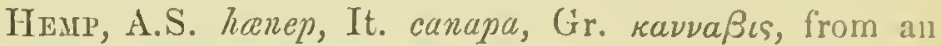
Oriental root. Herodotus speaks of the plant, (b) iv. (.. $7+4$ ) as a novelty lately introduced into Thrace from Seythia.

Cannabis sativa, $\mathrm{L}$.

Hemp-agriony, from its being elassed by the old herbalists with agrimony under the general name of Eujatorium, and the resemblance of its leaves to those of hemp,

Eupatorium eannabinum, L.

Hexp-NetTLE, or more properly Henp-DEAD-NetTr.e, from its flowers resembling those of the dead-nettles, and its leaves the leaflets of hemp, Galeopsis Tetrahit, L.

Henbane, a plant so ealled from the baneful effects of its seed upon poultry, of which Matthioli says (l. iv. c. 61) that "birds, especially gallinaceous birds, that have eaten the seeds perish soon after, as do fishes also." In old works it is ealled Henbell, A.S. henne-belle, a word that would seem to refer to the resemblanee of its persistent and enlarged ealyx to the seallop-edged bells of the middle ages, and the more so as the plant is called in some of the old plant-lists Symphoniaca, from symphonia, a ring of bclls to be struek with the hammer. Neverthcless this is possibly a ease, such as so frequently occurs, of accommodating an ill-understood name to a familiar object. The plant is ealled in A.S. belene, and belune, in German bilse, O.H.G. belisa, Pol. bielún, Hung. belénd, Russ. belenú, words derived (aeeording to Zcuss, p. 34) from an ancient Celtic God Belenus eorresponding to the Apollo of the Latins: "Dem Belenus war das Bilscukraut heilig, dis rou ilm Belisa und Apollinaris biess." It was from him that it was called in the Celtie language belinnentio, and from this word it is presumed that its name in other languages was 
derived. It is only in comparatively recent times that the bell has been replaced by bane, and it is difficult to see how it evcr was connected with henne, if the hemne referred to the bird so called. Hyoscyamus niger, $\mathrm{L}$.

НемвIт, G. hiüner-biss, 利. hoender-beet, I. morsus'gallince, from some fancied nibbling of its leaves by poultry,
" The greater-,
Lamium amplexicaule, L.
" The Lesser-,
Veronica hederifolia, L.

Hex's-Foot, a mere translation of Lat. pes pulli, a name that Stapel, in 'Theophrast. p. 812, says was griven to it from the resemblance of its leaves to a hen's claw, an observation that he must have made on a bad picture,

Caucalis daucoides, L.

Hepatica, an adopted Greek word, adj. of hepar, the liver, applied to a plant with three-lobed leaves, used in affections of that organ. "Hepatica in Hepatis morbis, quod folia visccris istius gerunt figuram." Limn. Bibl. Bot. p. 117. In the medieval writcrs, such as Platearius, it means a Marchantia, M. polymorpha, I. in popular language at the present day,

Ancmone hepatica, $\mathrm{L}$.

Herb Bennetr, L. Herba benedicta, Blessed Herb, the avens, so called, Platearius tells us, as quoted in Ort. San. c. clxxix, because "where the root is in the house the devil can do nothing, and flies from it: wherefore it is blessed above all other herbs." He adds that if a man carries this root about him, no venomous beast can harm him. 'The author of the Ortus says further, that, whicre it is growing in a garden, no venomous beast will approach within scent of it. Sce Avess. Geum urbanum, L.

" also the hemlock, from the same canse perhips, since we learn from Ort. San. c. lxxxvii. that, on Pliny's authority, serpents fly from its leaves, because they also chill to the deatl, "sye auch kelten biss auf den tod." 
Pliny, however, alludes to a different plant from this.

Conium maculatum, $\mathrm{L}$.

"also the valcrian, Sp. yerva benerletta, as being a preservative against all poisons, 'Tab. i. p. 471 ; and therefore "gut fur die biss der bösen vergifftigen thieren," Eays Brunschwygk.

Valeriana officinalis, L.

But in point of fact the proper name of these plants was not Herba benedicta, but Sit. Benedicti herba, St. Benedict's herb, G. Sanct Benedicten-krant, and was assigned to sucll as were supposed to bc antidotes, in allusion to a legend of St. Benedict, which represents, that upon his blessing a cup of poisoned wine, which a monk had given him to destroyhim, the glass was shivered to pieces. (Mrs. Jameson, Mon. Ord. p. 9).

Hers Christopher, a name vaguely applied to many plants which have no qualitics in common. Some, as aquatic plants, e.g. Osmunda, and Pulicaria, might refer to the saint's wading the river, and the Gnaphalium, a proliferous plant, to his bearing children on his shoulder, but we fail to see how he is connected with the others. The three to which it has been given by our own writers arelst, the baneberry, "but," says Parkinson, "from what cause or respect it is called so, I cannot learn,"

$$
\text { Actæa spicata, L. }
$$

2nd, the Osmund fern,

Osmunda regalis, $\mathrm{L}$. 3rd, the fleabanc,

Pulicaria dysenterica, Cass.

But besides these there are others which by the older herbalists are called Sti. Christophori herba, and Kristoffelskraut; such as Spiræa ulmaria, L. Gnaphalium germanicum, W. Betonica officinalis, L. Vicia Cracea and sepium $L$.

Herb Gerard, Du. Geraerts cmut, called so, sars Forster in Nat. Phen. p. 101, from St. Gerard, who used to be invoked against the gout, for which this plant was used as a remedy, Egropodium l'odagraria, L. 
HERB of GRACE, rue, from this word rue having also the meaning of "repentanee," which is needful to obtain God's grace, a frequent subjeet of puns in the old diamatists. See quotations in Loudon's Arboretum, vol. i. p. 485.

Ruta graveolens, L.

HERB ryrrous, from the younger flowers overtopping the older ones, like undutiful ehildren rising over the heads of their parents ; ob id impiam appellavere, quoniam liberi super parentem exeellant." Plin. Nat. Hist. (1. xxiv, 113).

Gnaphalium germanieum, Huds.

Herb Ivy, or Herb Ive, or - Eve, a name given to several different plants with deeply divided leaves, a corruption of the Abiga of Pliny. Beekmann, in lis Lexieon Botanieum, explains it thus: "Iva, Ruellius ibiga; hine duabus abjectis literis $i$ et $g$, $i b a$, et tandem $i v a$ manavit in vulgi nomenelationem." "The name las been given by the herbalists to

Ajuga Iva, Coronopus Ruellii, and Plantago Coronopus, L.

Herb Margaret, the daisy, see Marguerite.

Bellis perennis, $\mathrm{L}$.

Herr Paris, ineorrectly so spelt with a capital P, being its Lat. name Herba paris, Herb of a pair, of a betrothed eouple, in reference to its four leaves being set upon the stalk like a trulove-knot, the emblem of an engagement, whenee its synonym, Ilerb Trulove,

Paris quadrifolia, L.

Herb Peter, the eorvslip, from its resemblance to St. Peter's badge, a bunch of keys, whenee its German name, Schlïssel-blume, Primula veris, $\mathrm{L}$.

HERB RobErt, a greranium, that aeeording to Adelung, was so called from its being used to eure a disease known in Germany as the Ruprechts-Plage, from Robert, duke of Normandy, for whom was written the eelebrated medieal treatise of the middle ages, the "Regimen Sanitatis Salernitanum," or "Sehola Salernitana." In some old writers 
it is ealled Saneti Ruperti herba. See Bauhin de plant. sanet. p. 81. There are four saints of that name, and one of them, a bishop of Salzhurgr, is said by Allsan Butler in his Lives of the Saints to have eured all the maladies of body and soul. In a MS. vocalsulary of the 1.3th century, in Rel. Ant. vol. i. p. 37, it oeeurs as "/lerba Raberti, Herb Robert." Adelung's explanation is probably the eorreet one.

Geranium Robertianum, L.

Herb Trinity, L. Herba Trinitatis, G. dreifaltigkeitsblume, from having three eolours eombined in one flower, the pansy, Viola trieolor, L. and also from having three leaflets eombined into one leaf, Anemone hepatiea, L.

Hers twopence, from its pairs of round leaves, the moneywort, Lysinaehia Nummularia, L.

Herb William, in R. Turner's Botanologia, p. 45,

Ammi majus, L.

Heron's BLL, from the shape of the seed vessel,

Erodium, L'Her.

Hig-taper, HaG-TAPER, in Turner Hyggis-taper, in Lupton, i. 3, HEDGE-TAPER, ineorreetly spelt in our floras High-laper, from A.S. hege or haga, a hedge, the usual plaee of its growth. Dodoens tells us that it ras ealled Candela, "folia siquidem habet mollia, hirsuta, ad lucernarum funieulos apta ;" " a plant," says the Grete Herball, "whereof is made a maner of lynke, if it be talorred;" or, as Parkinson says, (Th. Bot. p. 62,) "Verbaseum is ealled of the Latines Candela regia and Candelaria, beeause the elder age used the stalks dipped in suet to burne, whether at Funeralls or otherwise." Brunfelsius, (ed. 1531,) says, p. 197, that it is ealled Tull-or König-kerz, "darum das sein stengel von vilen gedörrt würt, überzogen mit harz, waehs, oder beeh, und stangkerzen oder dartschen davou gemacht, und gebranut für sehaub-faekelen." See H.ırTAPER.

Verbaseum Thapsus, L. 
Hindberry, A.S. himdherie, M.H.G. himt-ber, O.H.G. hint-peri, a name that was once very generally given to the raspberry, and is still retained in some eountics, derived, apparently, from hind, as meaning the gentler, the tamer kind of bramble, contrasted with the heorot-berie, the hart-berry. Adelnng suggests its derivation from Lat. Incens, by a change that is quite consistent with analogy, viz. prefixing an $h$ to the initial vowel, and an $n$ before $l$.

Rubus idæus, L.

Hindhear, A.S. hind-hele, -heoleðe, or -hecle $\delta$, from its curing the hind, probably the same herb as the Elaphoboscum, which deer were supposed to eat when stung by scrpents, and of which Lnpton tells us, No. 80, that "it is said that harts in Crete being struck with darts envenomed, do eat of a eertain herb called Dittany, and thereby the prick that sticks in them, is driven ont." Teucrinm Scorodonia, L.

Hip-, or Hep-rose, the dog-rose, that which bears the hip, A.S. hiop, heap, heope, O.S. hiopa, O.H.G. hiofa, Norw.

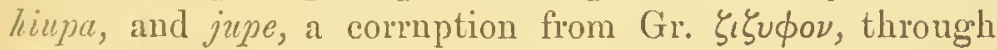
II. Lat. jujubu, the $j$ of which has become $h i$, as in many other instances, through the intermediate sound of $y$. Thus Job becomes in German Hiob, and jejunium, hunger, and conversely an initial $h i$ is in Norway always pronounced $y$; e.g. hierte, heart, yerte; and similarly in our own western connties heifer beeomes yeffer. It seems to confirm this view of the derivation of hip from jujuba, that the Ortus Sanitatis, the figures of which, bad as they are, are traditional copies of very aneient ones, gives (c. ccxx), a roscbush with hips on it for the Jujube, and titles the chapter: "Hanbotten, jujnbe grece et latine:" the hanbotte being the same as the laagebutle or hip. In the Old Saxon of the Heliand, hiopa seems to have meant the briar rather than the fruit: (1. 3488) "nec oe figun ni lesat an hiopon:" nor gather figs on hips: where hiopon represents the Gr. rpıßòos of Matth. vii. 16, a word that Wyclifle 
translates "breris," briars, but our autlorized version, less eorreetly, "thistles."

Rosa canina, $I$.

HIp-wonT, from the resemblanee of the leaf to the acetabulum or lip-soeket, whenee its former name of herba cosendicum, herb of the hips,

Cotyledon umbilicus, L.

Hinse, G. lirse, I. cerevisia, ale, from an ale being brewed from it, as in tropical Afiea to this day, a kind of millet,

Sorghum saccharatum, W.

Hock, or Hock-Hers, the mallow, from Lat. Alcea, ly the ehange of $l$ to $u$, and the usual prefix of $l$ to Lat. words beginning with a vowel upon their becoming English; $A l c$, auc, hanc. See Hollihock.

Althæa and Malva, L.

Hog's-FenNel, a eoarse rank plant, fennel for a hog,

Peueedanum officinale, L.

Hog-Nur, the pig-nut, Bunium flexnosum, With.

HOG-WEED, from the fondness of hogs for its roots, the eow-parsnep, Heraeleum Sphondylium, L.

Holtmock, in Huloet's Diet's. Holy Hoke, a perplexing word. The llock is elearly from the L. alcea, (see Hock, but the Holli is very difficult to explain. The most probable origin of it is L. caulis, with the meaning of a cule-, colcy-, or cabbage-liock, and referring, as in cabbagerose, to its well-filled double flowers, or used in the scnse of stalk, and referring to its lofty habit, in contrast with that of the lowly Hock-herb, or mallow. Cauli- or Culeyhock would easily pass into Holly-and Holy-hoch.

Althæa rosea, L. and fieifolia, Car.

Holdow-Wort, or Hole-wort, from its hollow root,

Corydalis tuberosa, DC.

Houly, or Holar, on the Eastern Border ealled Holdex, the old form of the word, and that from which hotm has heen formed by the eliange of $n$ to $m$, as lime from Iine: A.S. holen or holegn, a word deriver from L. uler, which in the middle ages was confused with ilex, the holm rak of the aneionts, whence the adjeetive uligua, and with the 
aspirate, huligna and holegn. The form Ilolly will have been the more readily adopted, and the tree have been called in Anglo-Saxon times elcbeam, or oil-tree, from its branehes having been used for olive branehes, and strewed before the image of Jesus, in eertain solemnities of the ehureh that represented his entranee into Jerusalem. 'Ihus in Googre's Naogeorg'us :

"He is even the same, that, long agone,

While in the streete he roade,

The people mette, and olive bowes

So thicke before him stroade."

Ilex Aquifolium, L.

KNEE-,
, SEA-,

Holly-, or Holir-oAK, see Holly.

Holy Girost, so called "for the angel-like properties therein," says Parkinson, (Th. Bot. p. 94l). "It is good against poison, pestilent agrues, and the pestilence itsclf," says IV. 'Turner (b. iii. 5.).

Angeliea sylvestris, $L$.

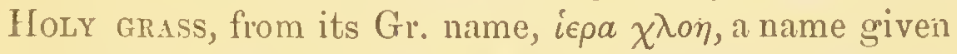
to it from "a praetiee in some parts of Germany of strewing it before the doors of eluurehes on festival days." Treasury of Botany.

Hierochloe borealis, $\mathrm{Rm}$.

Hor, IIAY, in some old works, the lueern, a mistaken translation of Fr. sain-foin. See Sarnforn.

$$
\text { Medicago sativa, L. }
$$

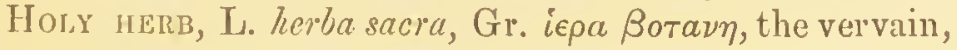

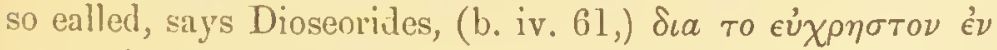

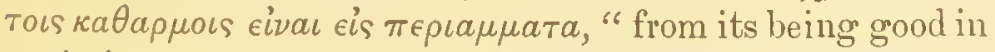
expiations for making amulets." It aequired this charaeter from being used to deeorate altars: "Ex ara sume verbenas tibi ; "Ter. in Andria; and, as Pliny tells us (b. 22, e. 2): "non aliunde sagmina in remediis publieis fuere, et in sacris legationibus, quam verbena;" and adds, "hoe est gramen ex ara eum sua terra evulsum." It would seem 
that branches of any lind used about the altar at sacred festivals were called verbena, and leeing borne by an ambassador rendered his person inviolable; and that the word did not originally apply exclusively to that which we now call vervain.

Verluena officinalis, L.

Holy rope, a plant that from its hemp-like leaves was named after the rope with which Jesus was bound; just as there was a Christ's thorn, a Christ's gall, a reed-mace, a Christ's ladder, etc., found to represent the other incidentz of the Crucifixion; the hemp agrimony,

Eupatorium eannabinum, L.

HoNesty, from the transparency of its dissepiments, Lunaria bicnnis, L.

Honewort, from its curing the hone, a hard swelling in the eheek so ealled, Ger. p. 101S, Trinia glaberrima, L. and Sison Amomum, L.

HoNEYSUCKLE, A.S. hunig-sucle, a name that is now applied to the woodbine, but it is very doubtful to what plant it properly belongs. In the A.S. vocabularies it is translated Ligustrum, which in other places means the cowslip and primrose. In Parkinson and other herbalists it is assigned to the meadow clover, which in our Western counties is still ealled so. This, too, is the plant meant by the rede homy suckle gres in the Stockholm MLed. MI.S. (Archæol. v. xxx. p. 399). The name seems to have been transferred to the woodbine on account of the honey-dew so plentifully deposited on its leaves.

In poetry and popular usage,

in farmer's language,

Honersuckle, Dwakf-,

"FLY-,

Lonicera, L.

" French-, a plant used on the Continent for fornge as the meadow clover is with us; a foreign honersuckleelover;

Hedysarum eorounrium, L.

HoNEY-Ware, A.S. war, sea-weed, and honey from its 
bcing covered with a layer of sugar, "dont les Islandais sc scrvent tròs bicn," says Duchesne, p. 364. Alaria esculentil, and Laminaria saccharina, Lam.

Hooded Mrlforl, Fr. millefenille, thousand leaf, from its very finely divided leaves and the hood shape of its corolla,

Utricularia vulgaris, L.

Hook-HEaL, from its being supposed, on the doctrine of signatures, to heal wounds from a bill-hook, which its corolla was thought to rescmble, Prunella vulgaris, L.

Hop, a name adopted from the Netherlands with the culture of the plant, Fl. hoppe, L. Gcr. hoppen, G. hopfe, M. Lat. lupa, Humulus Lupulus, L.

Hop-CLover, from the resemblance of its fruiting capitules to little heads of hop,

Trifolium procumbens, and agrarium, L.

Horehound, A.S. hara-hune, from hara, hoary, and hune, honey, a name that may lave been, and most likely was, suggested by that of another labiate plant, meliss, $\mathrm{Gr}$. $\mu \in \lambda \iota \sigma \sigma a$, honey, but may very possibly be a corruption of Lat. Urinarich; the plant having been regarded as one of great efficacy in cases of strangury and dysuria. See Ort. Sanit. ch. $256 . \quad$ Marrubium vulgarc, L.

Horenound, BLACK-, from its dark flowers,

Ballota nigra, L. " Water-, Lycopus europæus, L.

Hore-strange, or -strang, from its supposed virtue in strangury. Scc Harstrong.

Horхведм, or -веЕсн, from its rood being used to yolic horned cattle, "as well by the Romans in old time," says Gerarde, p. 14.79, "as in our own, and growing so hard and tough with age as to be more likc horn than wood,"

Carpinus Betulus, L.

Honswort, from its bi- and tri-fureate leaves,

Ceratophyllum, L. 
Horned Poppy, from its long curved liorn-like scedpods, Glancium luteum, L.

Horse-BaNe, from its being supposed in Sweden to cause in horses a kind of palsy, an effect that has been ascribed by Linnæus not so much to the noxious qualities of the plant itself, as to an inseet, curculio paraplecticus, that breeds in its stem (Syst. Nat. 610),

CEnanthe Phellandrium, Lam.

Horse-Bean, the variety of bean grown for the food of horses,

Vicia Faba, L.

HorSE-BEECH, see HuRsT-BEECH, of which it is a corruption.

HorSe-CHESNUT, said to be called so from its fruit being used in Turkey, the country from which we received it, as food for "horses that are broken or touched in the wind;" see Selby, p. 34. Parkinson says (Th. Bot. p. 1402): "Horse chesnuts are given in the East, and so through all Turkie, unto Horses to cure them of the cough, shortnesse of winde, and such other diseases." In this country horses will not eat them, and the name is more likely to have becn given to these nuts to express coarseness. The ingenious eonjecture of a writer in $\mathrm{N}$. and $\mathrm{Q}$. (3, ser, $\mathrm{x} .45$, ) that it was suggested by the eicatrix of its leaf resembling a horse-shoe, with all its nails evenly placed, has no support of ancient authors. Esculus Hippoesstanum, L.

Honse-CHIRE, the germander, from its groming after horse-droppings, Fr. chier, Teucrium Chamædrys, L.

Horse-Flower, Lyte, (b. ii. c. 14), from Flem. peerdbloeme, horse-flower, a name that it secms to hare acquired from the pyrum of its Latin name having been misunderstood to mean " pear," Flem. peere, and this word being confused with peerl, a horse, Mclampyrum sylvaticum, L.

Hors-heLe, -HEal, or-HEet, A.S. hors-elene, L. Inula Helenium, which by a donble blunder of Inula for himmula, a colt, and Ilelenium for something to do with heels or 
healing, has been corrupted into Hors-hele, and the plant employed by apothecarics to heal horses of scabs and sore heels,

Inula Helenium, L.

Horse-Hoor, from the shape of the leaf,

Tussilago Farfara, L.

Honse-Kxoв, a coarse knapwecd, Centaurea nigra, L.

HoRSE-MINT,

Mentha sylvestris, L.

Horse-yushroosr, from its size as compared with the species more commonly eaten, Agaricus arvensis, Sch.

HorSE-PARSLEY, from its coarseness as compared with smallage or celery,

HoRSE-RADISH, Smyrnium Olus atrum, L.

Horse-SHOE-VETCH, Off. L ferrum equinum, from the shape of the legumes, Hippocrepis comosa, L.

Horsetall, L. cauda equina, a name descriptive of its shape, and under which it was sold in the shops,

Equisetum, L.

Horse-thyae, a coarse kind of thyme,

Calamintha Clinopodium, Benth.

Hodnd's-BerRy-tree, or Hound's-tree, a mistaken equivalent for Dogwood; see DoGwood.

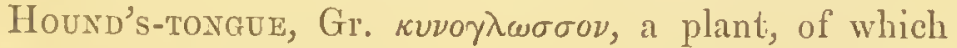
W. Coles tells us in his Art of Simpling, ch. xxvii., that "it will tye the Tongues of Houndes, so that they shall not bark at you, if it be laid under the bottom of your feet, as Miraldus writeth." The name was probably given to the Greek plant on account of the shape and solt surface of the leaf, and in contrast to the rough bugloss or ox-tongue.

Cynoglossum officinale, L.

HouSE-LEEK, a lcek or plant, A.S. lcac, that grows on houses,

Scmpervivum tectorum, L.

Hove, A.S. hufe, a chaplet, after its Latin namc, corona, Gr. $\sigma \tau \epsilon \phi а \nu \omega \mu \mu$, and so called, says Parkinson, "bccause it spreadeth as a garland upon the ground," the ground ivy, also called in old MSS. IIeyhowe, Heyouc, Haihouc, 
Halehoue, and Horshoue. Scc Pr. Pm. p. 250, note by Way.

Nepeta Glechoma, Benth.

Hulst, Du. Iutst, which Wciland derives from I. iles, but without accounting for the terminal $8 \ell$, which would seem in this, and scveral other words, to loc the Lat. celum, indicating the locality of its growth. Its immediate origin would thus be ulicetum for ilicetum, a bed of ulex or ilex, two names frequently confused in medicval writings, whence also G. huls, and Fr. houx. Ilex Aquifolium, L.

Hulver, in Chaucer Hulfeere, Fr. olicier, olive-trce, a name given to the holly from its being strown on the road in place of olive branches at the public festivals of the church; as was that of "palm," for a similar reason, to the flowering branches of the willow. See quotation under Holly. Ilex Aquifolium, L.

" KNeE-, the butcher's broom, see under KxeE-.

"SEA-, from its prickly leaves, and place of growth, Eryngium maritimum, L.

Hunger-grass, from its starving cereal crops among which it grows, and thus causing famine,

Alopecurus agrestis, L.

" -WEED, from its abundance indicating a bad crop, and season of famine, Ranunculus arvensis, $L$.

HURR-BURR, the burdock, whose involucres form the nucleus of the hardes or hurds, Norw. hör, the tangled lumps that are carded out of flax and wool,

\section{Arctium Lappa, L.}

Hurst- or Honst- or Horse-BeEcr, the hornbeam, from its growth on hursts, and some resemblance of its leaves to those of the becel-tree, Carpinus Betulus, L.

HunT-SICKLE, " because," says Culpeper, "with its hard wiry stem it turneth the edge of the sickle, that reapcth the corn;" called, for the same reason, by Brunsfelsius Blaptisecula, from Gr. $\beta \lambda a \pi \tau \omega$, injure,

Centaurea Cyanus, L. 
Hurtle-Berry, and Huckide-Berry, eorruptions of Thortle-berry, itself a eorruption of Myrtle-berry,

\section{Vaccinium Myrtillus, L.}

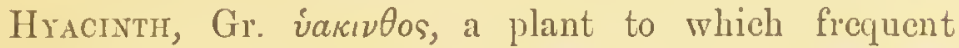
allusion is made by the Greek poets, but which, from the vague way in which they used the names of flowers, it is impossible to identify. It can searcely have been the hyacinth of our gardens. Some suppose it to have been the martagon lily, some a gladiole. The former seems to have been Ovid's plant, the latter that of the Sicilian poets, Theocritus and Moschus. But it would here be out of place to enter into the question. See Ovid, (Met. b. $x, 164$.) Theocr. (Id. $x, 28$. .) Mosehus, (Id. iii, 6.) As now understood, it is the genus Hyacinthus, L.

Hrssor, the name given in our authorized version of the Bible to some plant that has not been identified, but in popular language assigned to the supposed $\dot{v} \sigma \sigma \omega \pi$ os of Dioscorides, Hyssopus offieinalis, L.

Iceland Moss, a lichen so ealled from its abundance in Iceland, whence it is imported for medicinal and culinary purposes,

Cetraria Islandica, Ach .

It.Fx, a Latin name adopted and become popular, the holm oak,

Quercus Ilex, L.

Incarnation, in W. Turner's Libellus, the elove gilliflower, in mistake of the meaning of its name Coronation corrupted to Carnation, Dianthus Caryophyllus, L.

Inut, L. Inula, see Elecampane.

Ireos, the genitive ease of iris, used by apotheearies to mean the orrice root, raclix bcing understood. Sce OrRice. Irisir IfEath, from its oecurrence chicfly in the west of Ireland,

Menziesia polifolia, Jus.

Irisil, or Cariragezv Moss, a sca-weed so called, imported from Ireland,

Chondrus crispus, Lyngb.

IRON-HEADS, from the resemblanec of its knobled invo- 
lnere to a weapon with an iron ball fixed to a long handle, called a Loggrerhead,

Centaurea nigra, $\mathrm{J}$.

Ivray, Hr. ivraie, drunkenness. See Ray-grass.

Ivy, in MS. Sloane, No. 3489, 3, spelt Iryne, 1.S. ifig, a word strangely mixed up with the names of the yewtree, O.H.G. ëbah, from whieh, aceording to Grimm, arose ëbowe, ëbhowe, ebihowe, ephou, cpheu, and in Alsace epphau. It seems to have originated with the Lat. aliga, used by Pliny as the name of the plant ealled in Greek Chamepitys, and miswritten by some eopyist ajuga, which ras further eorrupted to the M. Lat. iva. See YEw. Lroking at the names of the two trees, the Ivy and the Yew, in the different languages of Europe, we eannot doubt that they are in reality the same word. Indeed in Höfer's "Törterbueh der in Oberdentsehland übliehen MIundart" we find that Ive or Ivenbaum belongs equally to one or the other. In English we get ivy from iva, and yew from the same word, written ina. The souree of the eonfusion seems to have been this. The Chamæpitys of Pliny, as we learn from Parkinson (Th. Bot. p. 284,) was "ealled in English Ground-pine, and Ground-ivie, after the Latin word Ira." But this name Ground-ivy had been assigned to another plant, which was ealled in Latin Hedera terrestris, and thus Iry and Hedera eame to be regarded as equiralent terms. But there was again another plant that was also ealled Hedera terrestris, viz., the ereeping form of Hedera helix, and as Ivy had beeome the equivalent of Herlera in the former ease, so it did in this too, and eventually was appropriated to the full-grown ever-green shrub so well-known. How iva beeame the name of the Yerr-tree will be explained below.

Hedera Helix, L.

Ivy, Ground-, see Ground-IVY.

Ivy-Leafed Chickiveed, Teroniea hederifolia, L.

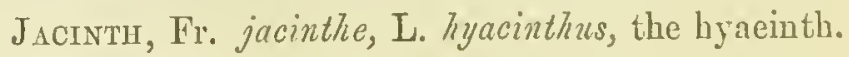


JACK BY THE IIEDGE, from Jack or Jakes, latrina, alluding to its offensive smcll, and its usual place of growth,

Alliaria offieinalis, L.

JACK OF THE BUTtery, a ridiculous name that secms to be a eorruption of Bot-theriacque to Buttery Jack, the plant haring been used as a theriae or anthelmintie, and called Vermicularis from its supposed virtue in destroying bots and other intestinal worms, Sedum acre, L.

JACOB'S LADDER, usually supposed to be ealled so from its suecessive pairs of leaflets, Polemonium eæruleum, $L$.

Jasuine, Jessauine, Jesse, or Gesse, Fr. jasmin, from Pers. jûsemîn, Ar. jầsamûm, Jasminum, $\mathrm{J}$.

JERSEY LIVELONG, from its occurrence in Jersey, and being of the same genus as many of the so-called everlasting flowers,

Gnaphalium luteo-album, L.

Jerusalem Artichone, ealled artichoke from the flavour of its tubers, and Jerusalem from It. girasole, turn-sun, that is, a sun that turns about, the sun-flower, to whieh genurs this plant belongs. By a quibble on Jerusalem the soup made from it is ealled "Palestine." Helianthus tuberosus, L.

Jertsalem Cowsurp, from being like a cowslip" "floribus primule veris purpureis," as deseribed by Lobel, and from having been confounded under the name of Phlomis with the Sage of Jerusalem, Pulmonaria offieinalis, L.

Jerisslem Cross, from an oeeasional variety of it with four instead of five petals, of the eolour and form of a Jerusilem eross,

Lychnis clialecdoniea, $\mathrm{L}$.

JertSALEI, OAK OF-, called oak from the resemblance of its leaf in an outline pieture to that of the oak, and its confusion under the name of $\chi a \mu a i \delta \rho v$, ground oak, witl the Chenopodium Botrys. The Jerusalem seems herc as in other eases to stand as a vague name for a distant forcign country.

Teucrium Botrys, L.

"Star of-, It. girasole, turn-sun, in allusion to the popular belief that it turns with the sun, whence it was 
also ealled solsccle, from Lat. solsequium, A.S. sol-sece, and star from the stellate expansion of the involucre. Sere Jerusalem Artichore, and SALSIFY.

'l'ragopogon porrifolius, L.

JEWS-EARS, L. auricula Jude, a fungus resembling the human ear, and usually growing from trunks of the elder, the tree upon whieh the legend represents Judas as having hung himself. Mandeville tells us, els. viii., that he saw the very tree. Exidia aurieula Judre, Fries.

JodN-, or JoNE-silven-PIN, the red poppy, ealled so, as Parkinson tells us, p. 367, beeause it is "Fair without and foul within," alluding to its showy flower and staining yellow juiee. Aceording to Forby the term "Joan's silver pin" means among the East Anghians " a single article of finery produeed oeeasionally and ostentatiously among dirt and sluttery," and in this sense too it is a fit name for this gaudy flower so eonspieuous among the reeds of the enrnfield.

Papaver Rhœas, L.

Jointed Charlock, from its pod being contraeted between the seeds, so as to appear artieulated, but being otherwise like eharloek, Raphanus Raphanistrum, L.

JoNQuIL, Sp. junquillo, dim. of junco, L. juncus, a rush, from its slender rush-like stem, Nareissus Jonquilla, L.

Joseph's rlower, Du. Joseph's bloem, the goat's beard, in allusion to its popular name of Go-to-bert-at-noon, and Joseph's refusal to do so, the implements and memorials of their aehievements and trials having been usually adopted as the badge of the Bible heroes, and exhibited in their pietures. Thus Samson had his jawbone, David his giant's head, Jonah his gourd, ete. Tragopogon pratensis, L.

Joubarb, Fr, joubarbe, see Jupiter's beard.

JUDAS TREE, from this, and not the elder, being the one upon which some of the legends represent that traitor as having hung himself, Cereis Siliquastrum, L.

Jily Flower, a term used by Drayton under the mistaken 
notion that it gave the meaning of Gilliflower, the stoek, Matthiola, L.

JuNIPER, from the Lat. Juniperus, a word of uneertain origin, J. eommunis, L.

Juro's Rose, L. rosa innonis, the white lily. We are told by Cassianus Bassus in his Geoponiea (l. xi. c. 20), that Jupiter, to make his son Hereules immortal, put lim to the breast of Juno while she was sleeping, and that the milk which was spilt, as the ebild withdrew from her, formed the milky way in the heavens, and gave rise to the lily upon earth. The story is curious as an instance of one that was transferred from the pagan to the Roman Catholie mythology; for it is evidently the souree of a similar one of the Virgin and the milk thistle. See Lyte, (b. ii. e. 42.) Lobel, (Kruydtb. p. 201.) Dodoens, (ii. 2. 1.)

Lilium eandidum, L.

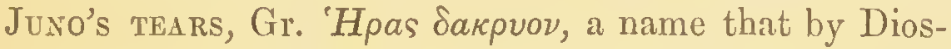
eorides was given to the Coix lacryma, now ealled "Job's tears," in allusion to its hard, polished, bead-like seeds, but through some eonfusion with the peristereon, as in Apuleins, c. 66 , transferred to the vervain, whieh has nothing about it that resembles a tear,

Verbena offieinalis, L.

JupITER's BEARD, Fr. joubarb, L. Jovis barla, the houseleek, so ealled from its massive inflorescenee, like the seulptured beard of Jupiter.

Quam sempervivam dicunt, quoniam viret omni

T'empore: barba jovis vulgari more vocatur:

Esse refert similem prædietæ Plinius istam. Macer.

Sempervivum teetorum, L.

Jupiter's staFr, R. Turner, (Bot. p. 216,) the mullein, Verbaseum Thapsus, L.

JuR-NuT, Da. jord-nöd, earth-nut,

Bunium flexuosum, L.

K.ILE, see CALE. 
KathaRINE's FLowTr, from the persistent styles spreading like the spokes of a wlieel, the symbol of St. Katharine, from her having been martyred upon a wheel,

Nigella damascena, I.

Kecks, Kex, Kecksies, Kaxes, Kixes, or Cashes, the dry hollow stalks or haulms of umbelliferous plants, $\mathrm{E}$ called from an old English word keek or kike retained in the Northern eounties (Broekett) in the sense of "peep" or "spy," Go. kika, Da. kige, Du. kijken, a uame suggested by their most obvious peeuliarity: viz., that one may look through them. It is eommonly given to the stems of the cow-parsnep and eow-parsley.

Kedlock, or Ketlock. See Chedlock.

KeLPWARE, a sea-ivrack or ware that produees lielp or barilla,

Fueus nodosus, and resiculosus, $I$.

KEMPs, the flower stalks of the ribwort plantain, A.S. cempa, a warrior; Da. kxmpe, a word peeuliar to the Northern eounties, and more probably of Danish than Anglo-Saxon origin, alluding to the ehild's game of fighting them against one another; one that is known in Sweden also, where they are ealled Kümpar and Kamp-gräs;

Plantago laneeolata, L.

KERNEL-WORT, from having keruels or tubers attached to the roots, and being therefore supposed, on the doctrine of signatures, to eure diseased kernels, or serophulous glands in the neek,

Serophularia nodosa, L.

KIDNEY-veTcH, beeause "it shall prevayle much against the strangury, and against the payne of the reynes." Lyte, (b. i. eh. 7).

Anthyllis vulneraria, $\mathrm{L}$.

KIDNEY-wort, from a distant resemblance of its leares to the outline of a kidney, Cotyledon Umbilicus, $L$.

KING's Crover, from its M.Lat. name corona regia, roral crown, "beeanse," as Parkinson says, (Th. Bot. p. 720 , ) "the yellowe flowers doe erown the top of the stalkes," as with a eliaplet of gold,

Melilotus offieinalis, $L$. 
King's cup or сов, O.E. cop, a head, from the resemblanee of the unexpanded flower-bud, and the blossom of its double variety, to a stud of gold, sueh as liings wore, Fr. bouton d'or,

Raumculus aeris and bulbosus, L.

Kixg's кмов, see Kisg's cup. A.S. cncep, a button, Da. knup and kinop.

Kipper or Knipper nut, ealled in Seotland knapparts, from knap, a knob, and urt, wort, the heath-pea, from its knotty tubers,

Vieia Orobus, DC.

KISS - ME - ERE-I - RISE, KISS-ME-BEHIND-THE-GARDEN-GATE, LOOK-UP-, or JUMP-UP-ANID-KISS-ME, see PANSY.

Kiss-Me-Twice-Before-t-Rise, R. Turner, (Bot. p. 22:3,) the fennel flower,

Nigella damaseena, L.

KNAP-HOTTLE, from its inflated ealyx, resembling a little bottle, and snapping when suddenly eompressed, Du. linappen, craek, snap, Silene inflata, L.

KN.P-Weed, KNop-, or KNob-Weed, Da. knopurl, from . its knob-like heads, A.S. cncep, L.Ger, knoop, Da. linap and kinop, G. Inopf', Centaurea nigra, $\mathrm{L}$.

Krawet, G. linauel or knänel, a hank of thread, from its spreading stems,

Seleranthus, L.

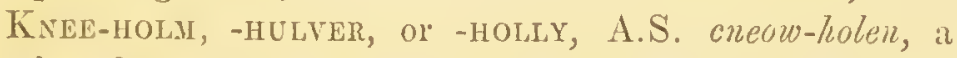
shrub referred to the holms or hollies on account of its cvergreen priekly leaves, and deriving the prefix kinee from eonfusion, under the name of daphne, and victoriola, with Lat. cneorum, a plant used in chaplets, as were some speeies of this genus. See Pliny, (N.H. xxi. 9.)

Ruscus aculeatus, L.

livigur's spurs, the larkspur, from its long, slender, projecting nectaries,

Delphinium, L.

Kingitr's-WORT, -WOUND-Wont, or -PONDworT, from its sword-like leaves,

Stratiotes aloides, L.

KNr'T-BAck, L. confirma, from being used als a strengthener or restorative, the comfrey,

Symplyytum oflicinale, L. 
Knob-tang, Da. tany, sea-weed, aud knol, A.S. cnarp, a word connected with many others becginning with len, lil, $g n$, and $g l$, in all the Germanic languages, and signifying a lump, or something linotted and hard,

Fucus nodosus, L.

Knolles, turuips, Du. Knol, Da. Rnold, a tuber,

Brassica liapa, L.

Krop-SEDGE, from the round hard capitules of seedvessels, the burr-recd, Sparganium ramosum, Huds.

KNOT-BERRY, from the knotty joints of the stems, Rubus Chamæmorus, L.

Knot-GRass, or KNot-wort, the centinode, from its trailing jointed stems and grass-like leaves. The "hindering knotgrass" of Shakspeare, (M.N.D. iii. 2), was probably so called from the belief that it would stop the growth of children, as in Beaumont and Fletcher's Coxcomb, $A$. iii. s. 2 :

"We want a boy

Kept under for a year with milk and knotgrass."

Polygonum aviculare, L.

That of Aubrey in his Nat. Hist. of Wilts, p. 51, and which is described by Fuller in 1662 as growing at Maddington near Salisbury, 24 fect in length, and by other writers as "Orcheston grass," from a village so named, was, according to Dr. Maton, (Linn. Traus. vol. r.) and Britton's Beautics of Wiltshirc, (vol. ii. p. i9), the fiorin grass, Agrostis alba, rar. stolonifera, L.

Kont-rabi, a German name, from It. carolo-raja, Fr. chon-rave, L. caulo-rapum, a calbage-turnip, a cabbage whose stem is swollen so as to resemble a turnip,

Brassica olcracea, var. gongylodes, L.

Laburnus, au adjective from L. labor, denoting what belongs to the hour of labour, and which may allude to its 
closing its leaflets together at night, and expanding them by day,

Cytisus Laburnum, L.

Lid's Love, the southernwood, see Boy's Love.

L.idderz to heaver, the Solomon's seal, ealled so, Parkinson tells us, (Th. Bot. p. 699,) "from the forme of the stalke of the leaves, one being set above the other," but more probably from a eonfusion of scel de Notre Dame, our Lady's seal, with échielle de N.D. our Lady's ladder. See below Lady's Seal. Convallaria Polygonatum, L. in Hudson, by mistake, Polemonium cæruleum, L.

LAdy's BEDSTRAW, see BedsTRAW.

Ladly in the names of plants almost always alludes to Our Lady, Notre Dame, the Virgin Mary, and often replaees, and is often replaeed by that of Venus. Thus Onr Lady's comb is the Venus' eomb, ete.

L.IDY's Bower, so named by Gerarde, p. 74.0, from "its aptness in making of arbors, bowers, and shadie eovertnres in gardens," Clematis Vitalba, L.

L.IDY's COsiB, from the long slender parallel beaks of the seed-vessels, Seandix Peeten Veneris, L.

L.IDY's cushion, from its close eushion-like growth, the thrift,

Armeria vulgaris, $W$.

LADY FEns, from its Latin name in modern works, Asplenium filix fœmina, Bern.

LAtyY's FLYGER, from its palmate bracts,

Anthyllis vulneraria, I.

I.IDY'S GARTERS, from the ribbon-like striped leaves, a rariety of

Digraphis arundinacea, PB.

LiJY's H.ıIr, the quake-grass, Briza media, L.

L.1ur's L.aces, doddler, from its string-like stems,

Cuseuta, L.

L.IDY'S LOOKING-GL.LSs, from the resemblance of its expanded flswer set on the elongated ovary to an ancient metallic mirror on its straightit handle,

C'ampanula liybrida, L. 
Iany's mantee, from the shape and the vandyked edere of the leaf, a translation of its Arabie name al kemelych, Sw. Mariekipa,

Lady's Navel, see Navelwort, Alchemilla vulgaris, $\mathrm{L}$.

Umbilieus pendulinus, DC.

L.IDY's NigHTCAP, in Wiltshire, (Akerman) the larger bindweed,

Convolvulus sepium, L.

L.idy's seal, or signet, M. Lat. Sigillum Slo Harie, al name that in the older writers is correctly given to a Convallaria, the plant now called Solomon's seal, from round cicatrices on the root-stock, which resemble the impressions of a seal, but which has been injudiciously transferred to a diffcrent plant, the black bryony, which has no such characteristic markings. This change seems to have bcen introduced by the herb-sellers, as the latter plant, the bryony, is described by Fernelius and others as one, "quar herbariis et officinis sigillum beatæ Mariæ nuncupatur." Ciesalpinus, and Mattliolus tell us that the former, the Convallaria, was called indifferently St. Mary's or Solomon's seal. "Sunt qui polygonatum sigillnm S. Marice, et qui sigillum Salomonis voeitent." Matt. in Diose. l. iv. c. 5 . "It is al one herbc, Solomon's seale, and our Ladr's seale," says the Grete Herbal. See Casp. Bauhin, de Plantis sanctis, p. 67.

The original plant, Convallaria polygonatum, L. The plant of modern writers, Tamus communis, L.

LADY's sLIPPER, from the shape of the labellum of its flower,

Cypripedium Calceolus, L.

LADY's sunck, from the rescmblance of its white flowers to little smocks liung out to dry, as they used to be once a year, at that season especially,

When daisies pied and violets blue,

And 7ady-smoetis all silver white,

And cuckoo-buds of yellow hue,

Do paint the meadows with delight. 
When shepherds pipe on oaten straws,

And maidens bicach their summer smocts, ete.

Shaksp. L.L.L., A. v. sc. 2.

Cardamine pratensis, L.

Lidy's тHIrbLe, ealled also TViтCH's thimble,

Campanula rotundifolia, L.

LAdr's THISTLE, the milk thistle, See above Jino's Rose.

Carduus Marianus, L.

LAD.Y's TrESSES, from the resemblanee of the flowerspikes, with their protuberant ovaries plaeed regularly one over the other, to a lady's hair braided,

Neottia spiralis, Rieh.

LAKE WEED, from its growth in still water, '

Polygonum Hydropiper, L.

LAMB's LETTUCE, formerly classed with the lettuees, and called in Latin Lactuca agnina, "from appearing about the time when lambs are dropped;" See Martyn, Fl. rustiea; or aceording to Tabernæmontanus, (i. 475), because it is a favourite food of lambs; Valerianella olitoria, L.

LAMB's QUARTERS, properly Lammas quarter, from its blossoming about the first of August, old style, the day of a festival instituted as a thanksgiving for the first fiuits of the harvest, when an oblation was made of loaves of the new eorn; the A.S. hlaf-mcesse, loaf mass, misscu panum, which in the Salisbury Manual is ealled Benedictio nororum fructuum;

Atriplex patula, L.

LAMB'S TOE, from its soft downy heads of flower's,

Anthyllis vulneraria, L.

LAmB's Torgue, Gr. $\alpha \rho \nu o \gamma \lambda \omega \sigma \sigma o \nu$, from the shape of the leaf,

Plantago media, L.

IAxcashire Asprotel, a plant allied to the asphodels and abundant in Laneashire, Nartheeium ossifragum, L.

LAXr: DE BEEF, Fr. langne de bauf, fiom the tongue shape and papillated surfaee of the leaf, the ox-tongue,

Ielminthia eehioides, Gärt. 
LARch, It. larice, the name with which it was introduced from the mountains of Italy, L. larir, Gr. $\lambda a p\llcorner\xi$, derived perhaps from its use in building and carpentry, L. lur, a house, O.N. and Russ. lar, a chest, Gr. $\lambda a p \nu a \xi$,

\section{Pinus Larix, I.}

LARK-SPUR, -HEEL, -TOE, Or -CLAW, from the projecting neetary,

Delphinium, I.

LAUREL, Sp. laurel, L. laurellus, dim. of laurus, a name originally applied to the sweet bay called in Chaucer, Douglas, and other early writers laurer, from Fr. laurier, but subsequently extended to other evergreens, and at present in eommon parlanee eonfined to the cherry laurel,

Prunus Lauroeerasus, L.

"Alexandrian-, from Paris, who is ealled in Homer Alexander, having been erowned with it as victor in the publie games, (Stapel in Theophrast. p. 253), whenee its names in Apuleius, e. 58, Daphne Alexandrina, and Stephliane Alexandrina,

Ruseus raeemosus, $\mathrm{L}$.

"BAY-,

Laurus nobilis, L.

„ COPSE-, or Spurge-, from its place of growth,

Daphne Laureola, L.

„Pontugal-, from its native eountry,

Prunus lusitanica, L.

" Roman-, from its being used in the chaplets worn by the Roman emperors, the siveet bay,

Laurus nobilis, L.

Laurustine, or more eommonly Latrustinus, L. laurus linus, from being regarded as a laurel, and as the shrub deseribed by Pliny, and by Ovid (Met. x. 98), under the name of Tinus, Viburnum Tinus, L.

Lavender, by ehange of $l$ to $r$ from Du. and G. larendel. It. lavandola, M. Lat. lavendula, from lavare, wash, as being the plant used to seent newly-washed linen, whence the expression of "laid up in lavender ;" or, as Diez tells us, from its being used at the baths in washing the body. 
In support of this last opinion C. Stephan tells us (De re hort. p. 54): "Lavenduia antem dicta quomiam magnum reetigal Genuensibus prebet in Africam eam ferentibus, ubi lavandis eorporibus Lybes ea utuntur, nee nisi decoeto ejus abluti mane domo egrediuntur." Lavandula Spiea, L.

Statiee, L.

Laver, A.S. laefer, L. laver, a name given by Pliny to some unknown aquatie plant, now applied to eertain esenlent sea-weeds, as $\quad$ Porphyra laeiniata, Ag. and

Ulva latissima, Grev.

LEEK, a remnant of A.S. porleac, from L. porrum, and leac, a plant, G. lauch, Du. look, Allium Porrum, L.

Lent-Lily, the daffodil, from the season of flowering, the spring, A.S. lencten, O.H.G. lenzo, Du. and Fl. lente, Nareissus Pseudonareissus, L.

Lentils, Fr. lentille, L. lenticula, Ervum Lens, L.

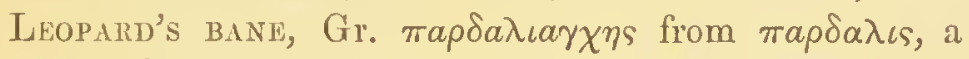
pard, and $\alpha \gamma \chi \omega$, choke, the name of some poisonous plant, whieh Nieander says in his Theriaea was used on Mount Ida to destroy wild beasts, transferred by Turner to the trulove, a very imoxious one, Paris quadrifolia, L.

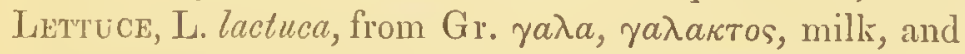
$\varepsilon \chi \omega$, eontain, through lattouce, an older form of the word that is still retained in Seotland,

L. sativa, L.
Lettuce, Frog's-,
Potamogeton densus, $\mathrm{L}$.
"Limb's-,
Valerianella olitoria, Mn.
WaLL-, a plant of the lettuee tribe found npon Prenanthes muralis, L.

walls,

Lice-B.se, the stavesacre, Delplinium Staphisagria, L.

Licires, Gr. $\lambda \epsilon \iota \chi \eta \nu$, a tetter, from its roundish, leprouslooking apothecia, as seen upon old buildings, Liehen, L.

Lichwale, or, as in a MS. of the fifteenth century, Lytinewale, stone-switeh, the gromwell, so ealled in allusion to its stony seeds, and their medicinal use in eases of calculus, from Gr. $\lambda \iota \theta 0 s$, a stone, through M. Lat. licho or 
lincho, a pebble, as in the Grant herbier, where the lapis demonis is called lincho- and licho-demonis, and wale, O. Fr. vanle, now gaule, from the Breton gwalen, a switch,

Lithospermum oflicinale, $\mathrm{L}$.

Licirwort, from its growing on stones (Eee LichWALE), the wall-pellitory,

Parietaria officinalis, L.

LiLAC, a Persian word introduced with the shrub, Syringa vulgaris, $\mathrm{L}$.

LiLy, L. litium, Gr. $\lambda \epsilon \iota p \iota o v$, of unknown, very ancient origin, used in some oriental languages for a flower in general, as in Cant. vi. 2-3, and Matt. vi. 28, and as rosje, rose, is used in the Illyrian; a trope of frequent occurrence among all nations, particularly the less cultivated races;

Lilium, L. its petals,

Checkered-, the fritillary, from the markings on

" Water-, Fritillaria Meleagris, L.

LiLY-among-Thorns, of Canticles ii. 2, L. Litium inter" spinas, understood by the herbalists as the woodbine, which, as W. Bulleyn says, "spredeth forth his sweete lilies like ladics' fingers among the thorns,"

Lonicera Caprifolium, L.

LiLY-OH-THE-vaLLEY, ol Lily-CoNvally, L. lilinm con-

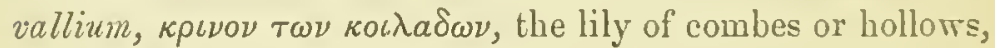
a name taken from Cant. ii. 1, "I am the lily of the ralleys," but not the flower mcant by the author, for this our English flowcr does not grow in Palestine,

Convallaria majalis, $\mathrm{L}$.

Lime, Line, or Linden-tree, called in all Germanic languages, and in Chaucer, Linde, a word connected with Ic. and Sw. linda, a band, and A.S. lide, pliant, which stands in the same relation to the continental name, as, c.g. Iriðer, cattle, to G. rind, and to to Fris. tond, that is having a final $d$ clanged to $\gamma$, and the $n$ omitted. The name has evidently been originally applied to the inner 
bark, or bast, of the tree so mueh used in the North for cordage. In the Merbals, and all old works after Chaueer's time, it is spelt Lyne or Line, as in the ballad of Robin Hood and Guy of Gisborne, wherc it rhymes to "thine :"

"Now tell me thy name, good fellow," said he,

"Under the leaves of lyne."

The $n$ has in later writers been changed to $m$, and lyne become lime, as hollen halm, henep hemp, and mayne maim. Linden is the adjeetival form of lind with 'tree' or 'timber' understood, and it is to be remarked that the names of most trees are properly adjectives, and in the Western counties are generally used with an adjeetival termination, as elmen-tree, holmen-tree, \&e.

Tilia europæa, L.

Line and Linseed, L. linum, Gr. Acvov, flax, probably a word adopted from a langruage alien to the Greek, upon the introduction of its eulture, Linum usitatissimum, $\mathrm{L}$.

Ling, Da. Nor. and Sw. lyng, a word which Holmboc considers to represent Skr. gangala, by a replaeing of $g$ with $l$, the common heath. This word is often combined with herle, a heath, as in $\mathrm{Sw}$. ljunghed, Da. lyngluede, ericetum, a heath-land, and conversely hedlelyng, the heathplant; leading to the belief that heath was the waste land. and lyng the shrub growing on it. See Diefenbach (Lex. Comp. ii. 496.)

Calluna vulgaris, $\mathrm{L}$.

Lion's-Foot, or -PAW, from the shape of the leaf resembling the impress of his foot, Alchemilla vulgaris, $L$.

LiRUORICE-veTCH, a veteh-like plant with a sweet root,

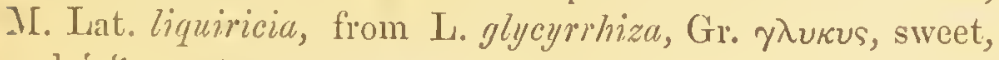
and $\dot{\rho} \iota \zeta a$, root, Astragalus glyeyphyllus, I.

LiRY-CONFAYCY, a eorruption of $\mathrm{L}$. lilinm convallium, lily of the valleys,

Convallaria majalis, $\mathrm{L}$.

LITIIY-TREE, from A.S. lið, pliant, a word etymologically identical with lind (See Linden); the tree being so ealled, because, as P'arkinson says: ('T'h. Bot. p. 144.8,) "the branches hereof are so tough and strong withall, that 
they scrve better for bands to tye bundels or any other thing withall, or to make wreathes to hold togrether the gates of fields, then either withy or any other the like," the wayfarce tree,

Vilsurnum Iantana, L.

Limius, G. lackmns, from lac, Skr. lakisha, a red dye, and moos, moss, a liehen, in popular language a moss, used in dyeing, the orehil,

Roecella tinctoria, Agr.

Litrlegoon, a plant so ealled on the Eastern Border (Johnst.) to distinguish it from the allgood,

Euphorbia Helioscopia, L.

Livelong, or Liblong, from its remaining alive hung up in a room. Brande in Pop. Ant. says that it is a habit with girls to set up two plants of it, one for themselves and another for their lover, upon a slate or treneber, on Midsummer eve, and to estimate the lover's fidelity by his plant living and turning to their's, or not. The name should probably be "Livelong and Liblong" (Lirc long and Love long). See Midsumarer mex.

Sedum Telephium, L.

Liverwort, from the liver shape of the thallus, and its supposed effects in disease of the liver. See Brunsehwrgk, (b. ii. e. 11).

Marehantia polymorplia, L. "Grouxd-, Peltidea ennina, Aeh.

"Noble-, in Ameriea ealled Liverleaf, and from its three-lobed leaves supposed to be, as Lyte tells us, (b. i. ch. 40 ,) "a sovereign medieine against the heate and inflammation of the liver," Anemone hepatiea, L.

LobGrass, from lot, or lop, to loll or hang about, as in loblolly, ete., so ealled from its langing panieles,

Bromus mollis, $\mathrm{L}$.

Locken, or Lucken Gowan, or Gowlon, a elosed goole or goldin, a term applied, aceording to Lightfoot and Jamieson, to the globe flower, called for the same reason, viz., its connivent petals, the cabbage daisy,

Trollius europæus, L. 
Loggerheads, from the resemblanee of its knobbed involueres to a weapon so called, consisting of a ball of iron at the end of a stick, the knapreed, the Clobbewed of old MSS.,

Centanrea nigra, L.

LoxDOx PRIDE, a name given in the first plaee to a speckled Sweet William, from its being a plant of whieh London might be proud, as was a similar name to the Mountain Pride, the Pride of India, and the Pride of Barbadoes, (see Parkinson's Parad. p. 320,) but of late years transferred to a saxifrage, which is commonly supposed to be so called, because it is one of the few flowers that will grow in the dingy lanes of a town. See Seeman's Journal, rol, i. It is understood, however, upon apparently good authority, that of $\mathrm{Mr}$. R. Heward in the Gardener's Chronicle, to have been given to this latter plant in referenee to the person who introdueed it into cultivation, Mr. London, of the firm of London and Wisc, the eclebrated Royal Gardeners of the early part of the last eentury.

$$
\text { Saxifraga umbrosa, } \mathrm{L} \text {. }
$$

Loxdoy rocket, called rocket from its leaves resembling those of an eruea, and London from its springing up abundantly in 1667 among the ruins left by the Great Fire,

Sisymbrium Irio, L.

LoNG PURPtes, of Shakspeare's Hamlet, (A. iv. se. 7,) supposed to be the purple-flowered orchis,

O. mascula, $L$,

Lonsestrafe, a translation of the Lat, lysimachia, as though the plant were called so from its stopping strife, Gr. $\lambda \nu \sigma \iota$ and $\mu a \chi \eta$. Pliny tells us (b. xxv. c. 35) that the name was given to it after a certain king Lysimaelus ; but, nevertheless, in deferenee to a popular notion, he adds that, if it be laid on the yoke of oxen, when they are quarrelling, it will quiet them. Isysimachia vulgaris, L.

" Purple-, Lythrum Salicaria, L.

LOLUS AND LADLES, from ehildren so calling the spadix 
of the Wakc Robin, as they find it to be purple or white; a name of recent introduction, to replace certain older, aud gencrally very indecent oues; Arum maculatum, L.

Lonen, its name in Chaucer and Gower from Fr. laurier, the swect bay,

Isaurus nobilis, L.

LOUSE-BERRY TREE, from its fruit having once been used to destroy lice in children's heads : "The powder kills nits, and is grood for scurfy heads." Dict. of Husbandry, under "Spindle tree;" and Loudon, (Arb. Brit. ii. 406);

Evonymus europrcus, L.

LOUSE-BUR, from its burs, or seed-pods, clinging like lice to the clothes, Xanthium strumarium, L.

Lousf-wort, "because," says Gerarde, p. 913, " it filleth sheep and other cattle, that feed in meadows wherc this groweth, full of lice,"

Pedicularis, L.

Lovage, in Pr. Pm. and in Holland's translation of Pliny, spelt, Love-ache, as though it were love-parsley, Fr. Levesche, corruptions of Lat. levisticum, whence also, through the same mistake, G. liebstöckel, and A.S. lufestice, and lulestice, Levisticum officinale, Ko.

Love, the virgin's bower; "The gentlewomen call it Love," says Parkinson, (Th. Bot. p. 3S4), from its habit of embracing, or, perhaps, from its forming natural arbours in which lovers may sit; Clematis Vitalba, L.

Love-APPLES, L. poma amoris, Fr. pommes d'amour, from It. pomi dei Mori, Moors' apples, this fruit having been introduced as mala cethiopica, Solanum Lycopersicum, L.

LovE-IN-A-MIST, ol -IN-A-PUZZLE, from its flowel being enveloped in a dense entanglement of finely divided bracts, Nigella damascena, L.

LOVE-IN-IDLENESS, or LOVE-AND-IDLE, or, with more accuracy, Love-IN-IDLE, i.c., in vain, as in the phrasc in Exod. xx. 7 : A.S., "Ne nem bu Drihtnes nameu on ydel" - "Tac bu noght in idcl min namen," a name of the pansy that perpctuates a current phrase, as in the couplet, 
"When passions are let loose without a bridle, "Then precious time is turned to love and idle;"

Taylor.

one of the many names of an amatory eharacter attaehed to this flower,

Viola trieolor, L,

LOVE-LIES-BLEEDING, fiom the resemblanee of its erimson flower-spike to a stream of blood, and the eonfusion of the two first syllables Aluar of its Latin name with amor, love,

Amarantins eaudatus, L.

LovEMAN, the goosegrass, a name given to it by 'Turner to express the $\mathrm{Gr}$. $\phi \iota \lambda a \nu \theta \rho \omega \pi \circ$, from its elinging to people,

Galium Aparine, L.

Lowry, or Laukr, L. lanea, adj. of laurus, laurel, the spurge laurel, which, on aeeount of its evergreen leaves, was ranked with the laurels, Daphne Laureola, L.

LucElswe, Fr. Zuzerne, apparently from the Swiss eanton of that name, but Diez and Littré say that its derivation is unknown. By some of the older herbalists the sainfoin was ealled so. At present the name is eonfined to the Medieago sativa, L.

LuJuld, eontraeted from It. Alleluiola, dim. of Alleluia; see Hallezujah. Oxalis Aeetosella, L.

Luxarie, L. Zunaria, from luna, monn, a name given to il great number of different plants. The following deseription of one is eopied by Gesner, in his treatise upon plants ealled Lunaria, from some anonymous author: "Lnnaria emicat in montibus humidis. Caule visitur proeero et rubente, anguloso, nigris asperso maeulis. Folia instar Lnure orbis, aut nummi alicujus, rotunda sunt, aut sampsuchi foliis similia. Flos lnteus; odor mosehi. Chymista facultatem fere eandem, quam ehelidonio ei attribuunt. Metallia omnia vi cjus in Solem et Lunam eonverti pollicentur. Noetibus lueere aiunt, erescente Luna. Colligi oportere restate pridie Divi Joannis Baptistre, Lmo pleni, ante ortum Solis; erescit enim (aiunt), et deereseit eum 
Luna." Gesner observes that "the clyymists, who first wrote in this way, and those who have sinee believed them, were either ignorant men, who easily and rashly placed relianee in the fables of others, and published monstrous deseriptions of plants that have no cxistence; or signified by enigmatieal deseriptions, not any plants, but things very different, as by the name of chelidonivm and elydrivm, I know not what quintessence or philosopher's stone." As at present understood, it is the forn that from its semilunar fronds is called Moonwort, Botrychium Lunaria, I.

LUNG-FLOWER, a translation of Gr. $\pi \nu \in \nu \mu o \nu a \nu \theta \eta$, from $\pi \nu \in \nu \mu \omega \nu$, lungs, and $a \dot{\alpha} \nu 0$, f florver,

\section{Gentiana Pneumowanthe, L.}

LUNG-Wont, L. pulmonaria, from pulmo, lungs, being supposed, from its spotted leaves, to be a remcdy for diseased lungs,

P. officinalis, L.

\section{„TreE-, Stieta pulmonaria, Hook.}

Lupine, L. lupinus, literally " wolfish," but supposed to

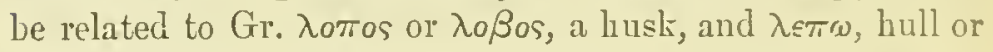
peel. If we had any reason to think it an Asiatic genus that was introdueed into Italy, we might explain its name as a translation of $\lambda v \kappa \epsilon \iota$ s, Lyeian, mistakeu for an adjective from גикоs, a wolf. Wedgwood's derivation of it from a Slavonian root is, for reasons geographical and historical, quite inadmissible. Lupinus, $\mathrm{L}$.

Lustwort, a name translated from Du. loopich-cruyllt, which, aceording to Dodoens, has that menning, and has been given to the plant, he says, "quia acrimonia sua sopitum Veneris desiderium exeitct," the sunder,

Drosera, L.

LYME-GRass, from L. elymus, $\quad$ E. europæus, L.

Lron's snap, from L. Leontostominm, Gr. גeovios, and бтopเov, the snapdragon, snap having formerly had the meaning of the Gr. $\sigma \tau o \mu\llcorner o v$, a little mouth,

Antirrhinum majus, L. 
MADDER, in old MSS. mailyr, from the plural of L. Ger. made, a worm, and ealled in an. Anglo-Saxon MS. of the thirteenth century vermiculum. See Mayer and Wright, p. 139. Hude is the same word as the Go. and AS. maða, whence mad, used by Tusser for a magrgot, and moth, whieh properly means the worm "that fretteth the garment," and not its winged imago, a word related to Go. matjan, eat, L. mandere, its root mall. The name was applied to the plant now ealled so from eonfusion with another red dye, that was the product of worms, viz., the cocci ilicis, which infest the Quercus coccifera, L., and which were called in the middle ages vermiculi, whence Fr. vermeil and vermillon, a term now transferred to a mineral colour.

Rubia tinctorum, $W$. Sherardia arvensis, L.

Madnep, the mead-nape, or -parsnep, or as it was once spelt, pas-nep, the eowparsnep. From Gerarde's assertion that "if a phrenetiche or melaneholic man's head be anointed with oyle wherein the leaves and roots have been solden, it helpeth him very much," it would seem as though pas-nep was misunderstood as It. pazzo-napo, mad turnep, and mead conformably changed to mad.

\section{Heraeleum Sphondylium, L.}

M.id-wont, Du. meerl, madder, for which its root was used, Asperugo procumbens, L.

MAGHet, maid, an adopted Flemish word, Go. magaps, O.H.G. magad, Fris. mageth, A.S. magð, Fl. maghet, as in the hymn beginning

"O, moeder ende maghet, reine vrouwe!"

Willems, No. 114.

Lat. flos virgineus, Gr: $\pi a \rho \theta \epsilon \nu \iota \nu$, a name given to many radiate composita with white ray florets, says Stapel in 'Theophrast. (p. S33, b.) "quod morbis mulierum nterinis medeantur;" an idea suggested by their fincied resemblance to the moon, whieh, from its regulating the monthly 
perinds of the year, was supposed to influence tloe corn. plaints peenliar to young women, and all affections of the womb. See Maithes, Margcherth, Mather, Machlas, Maruweed, Mayweed, and Moox-datsy. These plants were, in aneient times, and for the same reason, dedieated

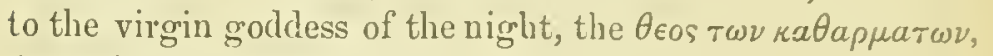
Artemis, or Diana; but in Christian times have l,een transferred to the two saints, who in this particular replace her, St. Mary Magdalene and St. Margaret.

Anthemis, Aehillæa, Pyrethrum, Bellis, Chrysanthemum, Matriearia, \&e.

MaIden-HaIr, from its hair-like fine stalks,

Adiantum Capillus Veneris, L.

Aeeording to Lobel (Kruydtboek, p. 126), the name of Maydlen heere was in his time given to the bog asphodel, "om dat de jonge doehters haer hayr daermede geel maeeken;" beeause young girls make their hair yellow with it. This fashion of dyeing the hair yellow was very" prevalent in the middle ages, but the lye of wood ashes was most generally used for the purpose, and as the employment of this plant is not notieed by other writers, nor any sueh name given to it, he was probably mistaken. See Maid's Hair. Nartheeium ossifragum, Lam.

MIaiden-hair-grass, G. (in Bauhin's 'Th. Bot.) jungfranen haar, but by Parkinson (Th. Bot. p. 1166, spelt Mead Hair-grass; in either ense from its delieate hair-like stalks; the quaking-grass, Briza medin, L.

MAIDEN-PINK, a mistake for MEAD-PLN, G. wiesen-nelke, a pink that grows in meadows, Dianthus deltoides, L.

MaId's hair from its soft floeenlent habit, like the loose un-snooded hair of maidens, and its yellow colour, to whieh, as a beauty in the hair of women, sueh frequent allusion is made by Chaueer and other romanee writers. Eren =o lite as Henry the Eighth's reign Horman says, "Maydens were silken eallis, with the whiche they keepe in ordre 
theyr heare made yclowe with lyc." See Way's Promp. Pm. p. 294.

Galium verum, L.

M.ırthes, that is maids, A.S. mage ðe, mag 內e, in $\mathrm{Pr}$. $\mathrm{Pm}$. and other old works mayde-wedle and maythys, from Gr. $\pi a \rho \theta \epsilon \nu ı \nu$, because, says W. Coles, "it is effectual against those distempers of the womb to which virgins are subject," meaning hysterics, and other irregularities of the system. See Maghet.

Pyrcthrum Parthenium, L.

", RED-, or RED MAYYDE-WEED, from its having been classed with the composite flowers called maithes, and its crimson colour, Adonis autumnalis, $\mathrm{L}$.

MaKebate, because, says Skinner, "if it is put into the bed of a married couple, it sets them quarrelling;" but a mere translation of its Latin name as if from $\pi 0 \lambda \in \mu o s$, war;

Polemonium cæruleum, L.

MALLow, A.S. malwe, L. malva, Gr. $\mu a \lambda a \chi \eta$, which Pliny and Isidore derive from $\mu a \lambda a \sigma \sigma \epsilon \iota \nu$, soften, as alluding to the laxative property of the plant, Malva.
" Mursh-,
"TREE-,
Althæa officinalis, L.
M. moschata, L.
Lavatera arborea, $\mathrm{L}$.

MandraKe, Gr. $\mu a \nu \delta$ payopas, a plant generally belicved to have been one nearly related to the deadly nightshade. Scc Hogg in Hooker's Journal, 2nd ser. vol. i. p. 132, and Smitl's Dict. of the Bible, art. Mandrake. Fraudulent dealers used to replace its roots with those of the white bryony cut to the shape of men and women, and dried in a hot sand bath. See Brown's Popular Errors, (b. ii. ch. 6,) Tragus, (ch. exxvi,) Stapel in Theophrast. (p. 583,) and especially Matthioli, (l. iv. c. 61,) where he tells us that Italian ladies in his own time had been known to pay as much as 25 and 30 ducats [aureos] for one of the artifieial Mandrakes of certain itinerant quacks; and describes the process by which they were made. They were supposed to remove sterility, a notion that has prevailed in the Eist 
from the remotest antiquity. Henee Rachel's desire to obtain them, as related in Gen. ch. xxx., v. 14. The rort used by these clealers was that of the common white bryony.

Bryonia disiea, $\mathrm{L}$.

Maxael Wunzer, literally "seareity root," but originally Mangold, a word of unknown meaning, and as Mengel or Menwel applied to doeks,

Beta vulgaris, L, var. hybrida, Sal.

ManNa-Grass, from the sweet taste of the seed,

Glyeeria fluitans, RB.

Map-Lichen, from the eurious map-like figures formed by its thallus on flat stones, Leeidea geographica, Hook.

MAPLe, A.S. mapel-treow, or mapulder, in Pr. Pm. mapulle, a word adopted from the language of the ancient Britons, and of early and general use throughout England, as is shown by the number of plaees named after the tree. It is elearly the Welsh mapul, a knob in the middle of any thing, and refers to the knotty exereseenee from the trunk of the tree, the bruscum, so mueh employed and so highly valued in the Roman times and in the Niddle ages for making howls and tables, that single speeimens of it have fetched many thousand pounds. See Pliny, (N.H. xvi. 2i,) and Smith, (Diet. Ant. art. Mensa.) The tree was naturally named after its most valuable produet, its mapul, and the word adopted, upon their arrival here, by the Anglo-Saxons.

Acer eampestre, L.

Maras, either the Gael. muram, or, as is more probable, the Fris. and Dan. marhalm, sea-haulm or straw, a word whieh in Norway is applied to the zostera and eertain fuei, but here to the grass ealled mat-weed,

Psamma arenaria, PB.

Manch or Merch, Da. märlee, Sw. meerki, the old name of parsley, preserved in stanmarch, the Alexander, and in the $G$. wasser-merke and Dir. vand-merke, eelery, formed from L. armoracia, in the fifteenth eentury ealled in German 
merich and mirrich, and to this day in Wetterau mirch. In I.S. the parsley is ealled merce, meric, and merici. Sce L. Diefenbach, Or. Eur. No. 26.

Apium, L.

MARE-BLoBs, from A.S. mere and myre, a marsh, and blob or bleb, a bladder, the marsh-marigold, so ealled from its round flower-buds, and usual place of growth,

Caltha palustris, L.

MAuE's TAI, a plant ealled in old herbals "Female Horse-tail," Lat. cauda equina fremina, being looked upon as the lemale of the larger and stronger Equisetum fluviatile. Modern botanists, following Hudson, have shifted the hyphen, and ehosen to understand the name as "Femalehorse Tail," or "Mare's Tail." Hippuris vulgaris, L.

Marguerite, from the French, the daisy, in Chaueer MargaretTs, a plant so ealled, not from its faneied innoeenee and simplieity, but beeause, for reasons given under ILAGHET, it was formerly used in uterine discases, which were under the especial care of St. Margaret, of Cortona. This lady, aeeorling to Mrs. Jameson, (Mon. Ord. p. 329), liad for some years led an abandoned life, but had repented and been canonised, and was regarded by the people of her native town as a loeal Magdalene, and, like her prototype, supposed, in respect of her early habits, to preside over the disenses of the womb, and others peculiar to young women. See Miudur. Her name has been mixed up with that of a St. Margaret, of Antioeh, who, aecording to Hampson, (Aled. Ev. Kal. ii. 257), "was invoked as another Lueina, beenuse in her martyrdom she prayed for lying-in-women." But it is the Cortona saint, and not this one of Antioel, whose name has been given to the daisy, and probably in the first place to the moon-daisy. 'The story of the maiden of Antioch,

"Maid Margarete, that was so meeke and mild ;" to whom it is popularly assigned, is given by Mrs. 
Jameson, (Sacr. and Legend. Art, p. 306.)

Bellis perennis, $I$.

Maniet, from the French, the Coventry luell, L. viula Mariana,

Campanula Trachelium, IJ.

Marigord, called in the Grete Herball Mary Goules, is name that secms to lave originated from the A.S. merscmear-gealla, marsh-horsc-gowl, the marsh marigold, or caltha, transferred to the exotic plant of our gardens, and misunderstood as "Mary gold." Its forcign synonyms lave no reference to the Virgin Mary. It is often mentioned by the older poets under the game of Gold simply.

Calendula officinalis, L.

" Corr-, from its place of growth, and yellow flowers, Chrysanthemum segctum, L.
" Marsh-,
Caltha palustris, $\mathrm{L}$.

Marjoram, or MLajoram, L. majorana, with change of $n$ to $m$, as in Lime, Holm, etc. Origanum Majorana, L.

Marmaritin, in Middleton's "Witch," Lat. in Pliny marmaritis, the peony,

Pæonia corallina, L.

Mariow, Vegetable-, from its soft and delicate flesh,

Cucurbita ovifera, W.

Marsh-Asphoder, a plant of the asphodel tribe, groming on moors, Narthecium ossifiagun, L.

Marsh-Beetle, ol -Pestle, from its shape, the reedmace, Typha latifolia, L.

Marsh-Cistus,

Marsh-Elder,

Marsh-Fern,

Ledum palustre, L.

Marsh-Flower, Limnanthemum nymphroides, Lk. Marsh-Holyruse, Andromeda polifolia, L.

Marsi-MLallow, Althæa officinalis, L.

Marsh-Marigold,

Marsh-Parsley,

Caltha palustris, L.

Marsh-Pennytiont,

Marsh-Samphire,

Viburnum Opulus, L. Aspidiun Thelypteris, Sw. Apium gravcolens, $\mathrm{L}$. Hydrocotyle vulgaris, $\mathrm{L}$. Salicornia herbacea, L. 
MIAisi-TrFforl,

MLRSH-WorTs,

IT.ARY-BUD, in the aubade in Cymbeline, (A. ii. sc. B), "And winking Marybuds begin

To ope their golden eyes :"
Menyanthes trifoliata, L.

Vaccinium Oxyeoces, I.

the marigold, Columella's "flaventia lumina calthr: " 1.97 :

"The Marigold that goes to bed with the sun,

And with him rises weeping:"-Wint. T. Ac. iv. sc. 3 :

ill allusion to its flowcrs, which, as Lyte says, "do close at the setting downe of the sunne, and do spread and open againe at the sunne rising:" a phenomenon to which the older pocts allude with great delight, both in respect to this flower and the daisy.

Calcndula officinalis, $\mathrm{L}$.

Maser-TREe, the maple, from the bowls or drinking cups, called masers, being made from the linotty parts of its wood, called in O.H.G. masar, whence M. Lat. scyphi maserini, Du. maes-hout, from maese, a spot, O.H.G. mazeldera, misel-tree, whence G. massholder. See Maple. Bowls made of silver and gold were called by the same name, as in Ritson's Ancient Popular Poetry, p. 77 :

\section{"Pecys of syluyr, masers of golde."}

Sec Pr. Pm. p. 325, Way's note. Accr campestre, L.

\aster-wort, a translation of its Latin name, Imperatoria, which was understood by the herbalists as indicating the masterly virtues of the plant, but has more probably becn given to it, with the sense of "Imperial," under the idea that it was the onc deseribed by Apuleius, c. 130, as having been used by Augustus under the names of Basilica and Regia, as a protcction against serpents : "Hac utebatur Iinperalor Augustus." Impcratoria Ostruthium, L.

Iatrelion, from L. maratriphyllon, fennel-leaf, $\mathrm{Gr}$. $\mu а \rho a \theta \rho o v \phi u \lambda \lambda o \nu$, called in the Ort. Sanit. c. 432, and in the Grete Herball, Marefolon, in Gerarde Matfellon, in Dodoens Malerfillon and "Malrefilon, voce, ut apparet, corrupta," in W. Coles Madefelon, in Parkinson Mutre- 
fillon, in old MSS. Maltefelone, Maudefelune, Madfeloun, ete. The Lat. maratriphyllon, the souree of all these barbarous terms, seems in the first plaee to have been giver1 to the water violet, Hottonia, on account of its fincly divided fennel-like leaves, and this is the plant which bears the name in Lobel and Pena's Kruydtboek, 1551, p. 965. From this it would seem to have been extended to other so-ealled violets, viz. the genus Viola, and the centauries. Thus in the Grete Herball, (eap. eeecii), we read "Jaeen, Herba elavellata, Torquea, Marefolon. Jacea is an herbe," ete. In H. Brunsehwygk, p. xlix, these synonyms are assigned to the pansy: "Freissam krut ron den krieehen torqueta, und von den arabisehen marefolon genant, und in latin yaeea nder herba elavellata, oueh von ettiehen dreifaltigkeit blumen genant umb dreyerley farb siner blumen, gelb, blow, und weyss." In the Ortus Sanitatis also it is figured and deseribed as a pansy, under the German name Freysehem-kraut, epilepsy-wort, and entitled "Jaeea vel herba elavelata, Latine, greee torqueta, arabiee marefolon." Jacea being extended to the genus Centaurea has carried the name from the violet tribe to the knapreed, but under the eorrupt form of Matfellon.

Centaurea nigra, $\mathrm{I}$.

Mat-grass, or Sirall Mat-weed, from its dense matlilie tufts, Nardus strieta, L.

Mat-rusi, the bulrush, from its use in making mats, Seirpus laeustris, $\mathrm{L}$.

MaT-WeEd, Psamma arenaria, R.S. and also the eord-grass, beeause as Gerarde says, p. 39, " these kindes of grassie or" rather rushie reede serve for to make mats and hangings for ehambers, frailes, baskets, and sueh like, and the people of the country where they grow do make beds of them, and stratre their houses and ehambers with them, insteede of rushes."

Spartina strieta, Sm. 
Mather or Mauther, a word used in the Eastern counties to mean a girl of the working class, O.N. madr, a man, a human being, a word from which it is probable that some prefix has been lost, a name applied to the wild chamomiles as a translation of their Greek name $\pi a \rho \theta \epsilon \nu \iota \nu$. See Maghet and Maitile.

Anthemis Cotula, L.

Maudlin, Maudeline, or Mawdeleyn, L. herba divce Marice, It. herba di santa Maria, so called after St. Mary Magdalene, either in allusion to her box of scented ointment, as containing this aromatic; or that, like other plants with white ray florets, it was employed in utcrine diseases, over which, as the especial patroness of loose women, she was supposed to preside. See Costmary and Maghet.

and

Balsamita vulgaris, L. Achillæa Ageratum, L.

Matdlin-wort, from its use in the same complaints as the above, the moon-daisy,

Chrysanthemum Leucanthemum, L.

It is necessary to observe that the monks in the middle ages mixed up with the story of the Magdalene, as recorded in Scripture, that of another St. Mary, whose early life was passed in a course of debauchery :

"Seint Marie Egipciake in Egipt was ibore.

Al hire yong lif heo ladde in sinne and in hore,

Unnethe zhe was tuelf yer old, ar zhe gon do folie,

Hire bodi and al here wille heo tok to sinne of lecherie."

Cott. Ms. Julius, D. ix., fol. 52, b, quoted by Hampson, ii. 257.

Her penance and pardon were a favourite subject for the legends of all Western Europe. The attributes of the impure groddess of the Egyptians, Isis, and of the Greek Artemis, and the Roman Juno Lucina, have been transferred in Roman Catholic times to this saint, and her counterpart, St. Margaret.

MaUle, the mallow, It. and $\mathrm{Sp}$. maula, by transposition of the $u$, from L. malva, M. sylvestris, L. 


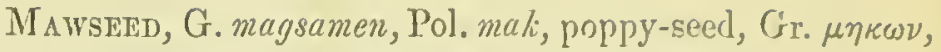

Mawther, see Mather.

Papaver somniferurn, L.

May or MaY-Bush, from its time of flowering, the hawthorn, Cratægus Oxyacantha, L.

MaY-LiLY, the lily of the valley,

Convallaria majalis, $\mathrm{L}$.

MaYweed, from may, a maiden, Da. mö, Ie. mey, and not from the month, a plant used for the complaints of young women. See Magriet. Pyrethrum Parthenium, Is. , Stinkrvg-, Matriearia Chamomilla, L.

MaYdweed, says Lupton, (b. 8, n. 46 ), "is a stinking hearbe, having a flower like a dayseye," one sn named from being used in the same cases as the mathers and mayweeds, Anthemis Cotula, L.

MAY-WORT from the month of its flowering,

Galium erueiatuın, L.

Mazzards, from L. manzar, cxplained in Pr. Pm. by "spurius, pelignus," a wild, a spurious eherry,

Meadsweet, see Mejadow Sweet.

Prunus avium, L.

Meadow Bouts, Fr. Zouton d'or, the wild Bachelor's button of moist grass-lands, Caltha palustris, L.

Meadow Clary,

Meadow Cress, Salvia pratensis, L.

Meadow Parsarip, Heraeleum Sphondylinm, L.

MeAdow Pink, the ragged Robin,

Lyehnis flos eueuli, L. and the maiden pink, Dianthus deltoides, L.

Meadow Rue, from its finely divided rue-like leares, whenee its name in old writers Peganon or Pigamon, from Gr. $\pi$ ryavov, rue, Thalietrum flarum, L.

Meadow Saffron, from the resemblanee of its flowers to those of the crocus or true saffron,

Colchieum antumnale, L. 
Meidow Saxifrage, from its leaves resembling those of the burnet saxifrage,

Silaus pratensis, Bess.

Meadotr Sweet, or, as in Turner, Mede-Swete, a meaningless name, a corruption of mead-wort, A.S. mede- or medo-uy.r, Da. miöd-urt, Sw. miöl-ört, the mead-, or honeywine-herb. Hill tells us in his Herbal, p. 23, that " the flowers mixed with mead give it the flavour of the Greek wines," and this is unquestionably the sourec of the word. Nemnich also says that it gives beer, and various wines, and other drinks an agreeable flavour. The Latin name, Regina prati, meadow's queen, has misled our herbalists, in their ignorance of its use, to form the ahove strangely compounded word Meadow-sweet. Spiræa ulmaria, L.

Mead-wort, or Mede-wort, the old and correet name of the so-called Meadow SweEt. Sec above.

Meal-berry, Da. meelbor, Norw. miölbor, from the floury character of the cellular strueture of its fruit,

Aretostaphylos Uva ursi, Spr.

Mealy-tree, from the mealy surface of the young shoots and leaves,

Viburnum Lantana, L.

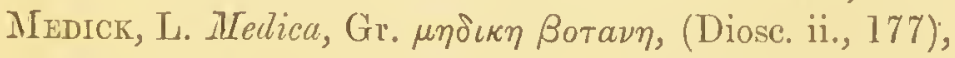
the name of some plant that according to Pliny (l. xviii. c. 43) was introduced into Greece by the army of Darius, and ealled so to mean Median. It seems formerly to have been given to a sainfoin, but is at present assigned to the Jueerne and its congeners. Medicago sativa, L., ete.

Medbar, called in Normandy and Anjou mestier, from L. mespilus, but as the verb mesler became in English meddle, so this fruit also, although a word of different origin, took a $d$ for an $s$, and becamc medlar.

Mespilus germanica, L.

Melanchuly gentleman, from its sad colour,

Hesperis tristis, L.

Melancholy thistle, from its supposed virtue in the eure of melaneholy,

Carduus heterophyllus, L. 
Melrlot, L. melilolus, Gr. $\mu \in \lambda \iota \lambda \omega t o s$, from $\mu \in \lambda \iota$, boney, and $\lambda \omega$ тоs, a name applied by Greek writers to some very different plant from the one at present called so,

Melilotus officinalis, J.

Melon, Fr. melon, from L. meloncm, obj. case of melo, Gr. $\mu \eta \lambda o \nu$, an apple, M. Lat. melo, Cucumis Melo, L.

Merche, see Marche.

Mercury, a name rather vaguely applied in old works, and now limited to a poisonous weed, from the god Mereury, in respeet of some fancied activity in its operation; or, aecording to Pliny, from its having been discovered by him ;

Mereurialis, L.

"DoG's-, from its worthlessness,

Mereurialis perennis, $\mathrm{L}$.

"English-, the all-good,

Chenopodium Bonus Henrieus, L.

, French-,

Mereurialis annua, $\mathrm{L}$.

Mercury's Violet, the Mariet,

Campanula Traehelium, L.

Merry, Fr. merise, mistaken for a plural noun, as cherry from cerise, L. mericea, adj. of merica, some berry mentioned by Pliny, the wild eherry, Prunus avium, L.

Mew, Gr. $\mu \eta$ v, $\quad$ Neum athamanticum, L.

Mezereon, a name derived by Mesue from a Persian name signifying a "destroyer of life," but by others from Arab. maczeroun, a dwarf olive, a name adopted by the herbalists from the writings of the Arabian physicians, Daphne Mezereon, L.

Michaelmas Daisy, from its resemblanee to a daisy, and its season of flowering, Aster Tradeseanti, L.

Midsumaer Datsy, the moon datsr,

Chrysanthemum Leneanthemum L.

Midsumer men, from a eustom of girls to try their lovers' fidelity with it on Midsummer erc. See Linelore. Sedum Telephium, L. 
Migroxetre, dim. of Fr. mignon, darling, from G. minne, love, a name applied in France to several very different plants,

Reseda odorata, L.

Mindew, A.S., mele-deau, from melu, meal, and decu, deu, G. mellthcut, a name deseriptive of the powclery appearance upon leaves and stems of plants from the growth of eertain minute fungi; that of wheat,

Puceinia graminis, $\mathrm{P}$.

Mirfort, Fr. mille and feuilles, L. mille foliola, from the numerous fine segments of its leaves, a name under which Apuleius seems to have meant the horsetail, Equisetum, describing it (in e. 99) as a plant "thyrso unius radicis, molli, fulvo, ita eoxquato atque elimato, ut manufactus videatnr, foliis f'œnieuli similibus ;" but at present given to the yarrow,

$$
\begin{aligned}
& \text { "Hooned-, } \\
& \text { "WATrR-, }
\end{aligned}
$$

and also the water violet,
Achillæa Millefolium, L.

Utrieularia, L.

Myriophyllum, L.

Hottonia palustris, $\mathrm{L}$.

Mirk Parster, from its millyy juiee,

Peucedanum palustre, Mn.

Mrlk-thistle, a thistle supposed to have derived the colour of its leaves from the milk of the Virgin Mary having fallen upon them, as she nursed the infant Jesus, a fable suggested by the similar one of the lily having been whitened by the milk of Juno as she nursed the infant Hereules. See Juno's Rose.

$$
\text { Silybum Marianum, DC. }
$$

MILK-VETCI, from a belief that it increased the seeretion of milk in the groats that fed on it, Astragalus, L.

MILK-Wort, a translation of its Greels name in Dioscorides, $\pi o \lambda v$ ya 0 ov, a plant called so, says Gerarde, (p. 450 , ) from its "virtues in proe'rring milk in the breasts of nurses," Polygala vulgaris, $\mathrm{L}$. 
Mrte-Mountain, from the Lat. cha-moel-inum monlanum, Gr. $\chi a \mu a l-\lambda(\nu o \nu$, ground flax, the fairy flax,

Linum catharticuin, L.

MrLrew, Fr. millet, from L. milium, a name, which, for want of good distinetive terms, is popularly extended to several different species of the grenera

Milium, Panicum, Paspalum, and Sorglium.

Mrutwaste, the finger-fern or ceterach, of which Du Bartas says, p. 79 (Sylvester's transl, 1611):

"The Finger-ferne, which being given to swine,

It makes their Milt to melt away in fine ;"

a notion adopted from an assertion made by Vitruvius, as quoted by Matthioli (1. iii., e. 134), that in the island Crete, near the river Poterius, which flows between Gnosus and Cortyna, on the side towards Cortyna, the flocks and herds were found without spleens because they browsed on this herb; while, on the other side, towards Gnosus, they had splecns because it docs not grow there. WT. Coles, to improve the story, tells us that "if the asse be oppressed with melancholy he eates of this herbe, Asplenion or Miltwaste, and so cases himself of the swelling of the spleen." The notion was probably suggested, on the doctrine of signatures, by the lobular milt-like outline of the leaf in the species to which the name was originally given, the ceterach; a species which is now rather inconsistently made the type of a genus bearing this last name of "Ccterach," while another sct of plants, in no respect rescmbling a spleen, are called "Spleenworts," and "Miltwastes." The enlarged splecn, called ague-cakc, was that which it was supposed to waste or diminish when given medicinally: Gerarde and other herbalists praise its efficacy in all infirmities of this organ. W. Bulleyn indecd says (fol. l) that " no herbe maie be compared therewith for his singular vertuc to help the sickness or grief of the splenc."

Asplenium Ceterach, L. 
Mrvт, L. mentha, Gr. $\mu \iota \nu \theta \eta$.

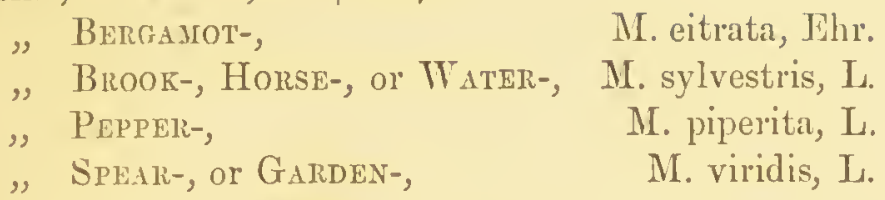

Mistletoe, A.S. mistiltan, a name that at first sight seems to be derived from mistl, different, and tan, twig, and to have been given to the shrub from its being so unlike the tree it grows upon; a feature which Baeon in his Natural History (eent. vi. 556) has noted as its distinguishing eharaeter. "It is a plant," says he, "utterly differing from that upon which it groweth." But by some eminent philologists this easy explanation is rejeeted, and the word derived from mist, exerement. It is not improbable that its Latin name viscum may have been confused with viscus, entrails. What other eonnection there is or ean be between mist and mistletoe, it is diffeult to see. The name is the same, viz. mistel or mistil, in all the Germanie languages, and its root in this view of it, migh, mingere. The Greek name $i \xi_{o s}$ is identical with Lat. riscum, and throws no light upon the question. It has been called mistil in O.H.G. from the most ancient times: see Graff, s. v. Sibthorpe, as quoted by Walpole, (Travels, vol. i. p. 265, , says that "the true misletoe of the aneients is the Lorantlus Europæus, whieh is still ealled $\partial \xi_{0}$ s, and from which birdlime is prepared. Our misletoe grows also in Greece, but is not to be found on the oak, but on the silver fir, and abounds on Parnassus, where it is ealled not ó $\xi_{\text {òs but }}$ $\mu \epsilon^{\prime} \lambda \lambda a$, and is gathered by the herdsmen as food for the labouring oxen." Whatever the aneient Greek worl $i \xi o s$ may have meant, it is probable that the viscum of the Latin writers in their aecount of the Druids was not this latter species, but the loranthus, one which grows upon the Quereus puleseens, I. an oak indigenous to the South of France, lut not to this country. Viseum album, L. 
Mitriridate Mustalen, from being userl in a medicinc, named after Mithridates, a king of Pontus, who invented, as an antidote to all poisons, the famous preparation called after him Mithriduticum, into which this plant, among many morc, was subsequently introdued. The original prescription, discovered by Pompey among the archives of the king, was very simple. Q. Screnus tells us that

\section{"Magnus scrinia regis}

Cum raperet victor, vilem deprehendit in illis Synthesin, et vulgata satis medicamina risit : Bis denum rute folium, salis et breve granum Juglandesque duas, terno cum corpore ficus."

Other ingredients, animal as well as regetablc, were added to it from time to time, and the name changed to Theriaca. See Treacie Mustard. Thlaspi arvense, L.

Mithridate Peppermort, Lepidium campestre, $\mathrm{Br}$.

Mock-PLANe, the sycamore, a translation of its Latin specific name, Acer Pseudoplatanus, L.

Mouy, the name of a plant in Homer's Odyssey, and occasionally introduced into modern poetry, as in Milton's Comus, (1. 636,) but not identified with any known species, and probably meant by Homer to be understood allegorically. See notc on this subject in Harwins's Milton, vol. iv. p. 89.

MONEY-FLOWER, from its glittering round dissepiments left after the falling of the valves, Lunaria biennis, $\mathrm{L}$.

MoneY-wort, the herb Twopence, so called from its pairs of round leaves, Lysimachia Nummularia, L.

„Connish-, from its round leaves, and its groming in Cornwall,

Sibthorpia europea, L.

Monkshood, from the resemblance of the upper sepal to the cowl of a monk, Aconitum Napellus, L.

Monk's Rhubarb, a dock that, according to Tabernæmontanus (p. 824), was so called, "dicweil dic wurzel der 
Rhabarbaren ähnlich ist, und von den Barfüssern und Carthaüsern in den klostern eine zeitlang heimlich gehaltel ;" aceording to Parkinson, from its being the doek deseribed as a rhubarb by the monks who commented upon Mesues.

Rumex Patientia, L.

Moon DaIsY, a large daisy-like flower resembling the pietures of a full moon, the type of a elass of plants, which, on the doetrine of signatures, were exhibited in uterine eomplaints, and dedieated in pagan times to the goddess of the moon and regulator of monthly periods, Artemis, whom Horsley (on Hosea ix. 10) would identify with Isis, the goddess of the Egyptians, with Juno Lueina, and with Eileithuia, a deity who had speeial eharge over the funetions of women; an office in Roman Catholie mythology assigned to Mary Magdalene and Margaret. See Mauduin, MarGUERITE, and MAGHET.

Chrysanthemum leuean themum, L.

Moox-wort, a fern so called from the semilunar shape of the segments of its frond, Botryehium Lunaria, Sw.

Moor-BaLLS, from their globular form and oeeurrenee in the lakes upon moors,

MOOR-grass, Conferva ægagropila, L.

Mook-whin, or Moss-whin, a whin that grows on bleak heaths and mosses,

Moor-wort, see Worts,

Genista angliea, L.

Monel, Hr. morelle, It. morello, dim. of moro, a Moor, I. Maurus, so ealled from its blaek berries.

"Great-, the deadly nightshade,

,

PETTY-, the garden nightshade, Atropa Belladonna, L.

Solanum nigrum, L. also a fungus, Fr. morille, Morehella eseulenta, P.

Morgeline, Fr. morsgeline, from L. morsus galline, the henbit,

Veroniea hederifolin, L.

Moschatele, It. moscatellina, froin L. moschus, musk, 
through mosco, moscado, musky, and its dim. moscadello, a plant so called from its faint musky odour,

Adoxa Moschatellina, L.

Moss, Fr. mousse, L. muscus.

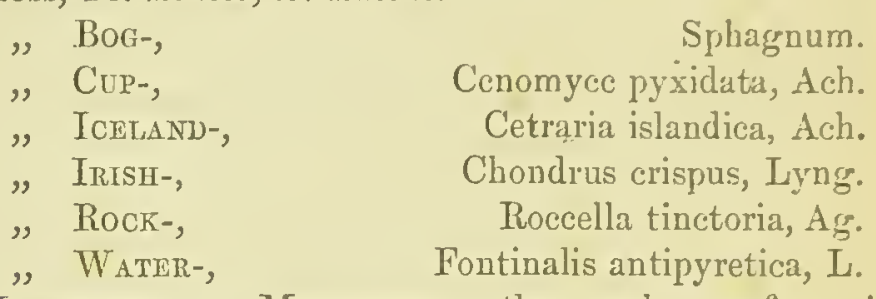

Moss-berry, or Moor-Berry, the cranberry, from its growing on moors or mosses, Vaccinium Oxycoccus, L.

Moss Canpion, from its moss-like growth,

Silene acaulis, $\mathrm{L}$.

Moss-crops, from crop, a head of flowers, and its place of growth. Ray and Plukenet (Alm. p. 201) say that in Westmoreland it is called by this name, because sheep are fond of it. It means merely moor-flowcrs.

Eriophorum vaginatum, L.

Moss-RUsin, from its growing on heaths and mosses, Juncus squarrosus, L.

Mother of Thousands (Treas. of Botany) a pun on its old name penny-wort, Linaria cymbalaria, L.

Mother of Thyme, a name that uudoubtedly ought to be written IIother-Thyme, as meaning "womb-thyme," having been giveu to this plant from its supposed effect upon the womb, which in our old writers is called mother, a use of the word adopted from the Flemish. According to Isidore (c. ix.) this plant was iu Latin also called "matris animuln, quod menstrua morct." Hence, too, its German names Quendel and Kuttelliraut. See HörER, vol. ii., p. 184. Platearius says of it:

"Serpyllum matricem comfortat et mundificat. Mulieres Salernitanæ hoc fomento multum utuntur."

The nearly allicd genus Melissa is, for the same reason, 
called by Herbarius (c. 84) Muderkrut, a word exaetly equivalent to IIotherwort. See below.

Thymus Serpyllum, L.

Motherwort, so ealled, says Parkinson (Th. Bot.p. 4.4), from its being "of wonderful helpe to women in the risings of the mother," i.e. hysteries, Leonurus Cardiaca, L.

", also in old works the mugwort, whieh, from its being used in uterine diseases, was called moder-wort, womb-wort, a name that by Xlfric is correctly rendercd matrum-herba, wort of mothers, but by later writers misunderstood and rendered mater herbarum, mother of worts. Thus Maeer (e. i.) -

"Herbarum matrem justum puto ponere primo:

Præcipue morbis muliebribus illa medetur."

Indeed its use in these affeetions was so general that Ray tells us (Cat. Plınt. p. 29), quoting the words of Schröder:- "Uterina est, adeoque usus est ereberrimi muliereulis, quæ eam adhibent interne et externe, ut vix balnea et lotiones parent in quibus artemisia non eontineatur." Like other uterine herbs it was dedieated to the gouddess of the moon, Artemis, and thence its Latin name. Artemisia vulgaris, $\mathrm{L}$.

MovLd, in ink and other fluids, usually

Mouldiness, Hygroerocis, Ag.

Mountain Ash, a trce whieh from its pinnate leaves is popularly ealled an $A s h$, the wild service tree, or rowan, Pyrus Aueuparia, L.

Mountain Cowslip, Primula Aurieula, L. Mountais Elm, the wyeh elm, Ulmus montana, L. Mountala Fern, Mountaix Sorrel, Aspidium Oreopteris, Sw.

Mouse-BARLEy, G. maus-gerste, Siv. mus-korn, a translation of its Latin name, which was given to it cither from the belief that it was the Colium murinum of Pliny (l. xxii. 
c. 25), or, through a confusion between murinum, of a mouse, and murale, of a wall, to express that it was a wallbarlcy; and this last is the most probable origin of the name, sincc 'Tragus tells us that it was called so, because it grows upon walls: "weil es von sich selbst auf den Mauren wächst;" and Dr. Wm. Turner (pt. ii. p. 17): "that it was called of the Latines Hordeum murinum, that is wall-barley."

Hordeum murinum, L.

MousE-Ear, from the shape of the leaf,

\section{Hieracium Pilosella, L.}

Mouse-ear Chickweed,

Cerastium rulgare, $\mathrm{L}$.

Modse-Ear Scorpion-grass, the plant now called "Forget-me-not," from its one-sided raceme being curved likc that ereature's tail, and its small soft oval leaves,

Myosotis palustris, L.

Mouse-TaIL, from its slender cylindrical seed-spike,

DIyosurus minimus, L.

Mouse-tail Grass, Martyu in Fl. rustica, from the sliape of the spike,

Alopecurus agrestis, L.

Moutan, from the Chinese Meu-tang, king of flowers, the tree peony,

Pæonia Moutan, L.

Mudwort, from its place of yrowth,

Limosella aquatica, L.

MugGet, Fr. muguet, O. Fr. musquet from L. musquettus, a dim. of muscus, musk, a name applied in French to several flowers, and to the nutmeg as noix muguette, in English from the aromatie odour of its roots to the lily of the valley, Fr. muguet de Mai, Convallaria majalis, L.

Mugget, Petry-, Fr. petit-muguet, little dandy, a word applied to cffeminate dressy young men, Jemmy Jessamies, with puffy yellow hair, Galium verum, $\mathrm{L}$.

MUG-WEET, Goldex-, a corruption of Fr. muguet,

Galium eruciatum, DC.

Mug-wort, a name that eorresponds in meaning with its syuonym wyrmwyrt, wormwood, from O.E. mough, moghe, 
or moughte, a maggot or motli, a word used by Hampole

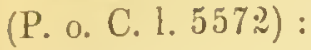

"And wormes and moghes on pe same manere Sal pat day be in wittenes broght ;"

and by Wycliffe (Matt. vi. 20) :

"Where neper ruste ne moughte destruyep;"

a name given to this plant from its having been recommended by Dioscorides to ward off the attacks of these insects; whence Macer (c. 3) dc Absinthio:

"A tineis tutan reddit qua conditur arcam."

and Trm. Bulleyn, speaking of wormwood, says, fol. 2 :

"It kepeth clothes from wormes and mothes."

The same plant having been used in uterine affections, and thence called Motherwort, may have been allowed to retain this antiquated name of Mugwort when used against moths, to prevent confusion with other motherworts.

Artemisia vulgaris, L.

Mercberry, by a change of $r$ to $l$, from L. morus, Gr.

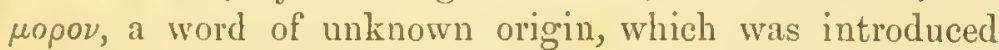
into Greece with the tree,

M. nigra, L.

Mullein, or White Mullein, in old works Molayne, A.S. molegn, the hig-taper, Fr. moleine, the scab in cattlc, O.Fr. malen, L. malandrium, the malanders or leprosy, whence malandrin, a brigand, from lepers having been driven from society, and forced to a lawless life. The term malandre was applied to other diseascs of cattle, to lung diseases among the rest, and Marcellus Empiricus explains it as " morbus jumenti quo tussit." The hig-taper, being used for thesc, acquired its names of Mullein, and bullock's lungwort.

Verbascum Thapsus, L.

" Petry-, the cowslip. "Those herbes," says Gerarde, "which at this day are called Primroses, Cowslips, and Oxelips, are reckoned among the kinds of Mulleins, 
for that the ancients lave named them Verluasculi, that is to saie, small Mulleins."

Primula veris, Is.

Mullet, Fleabane-, a plant used to destroy fleas, and called mullet, Fr. mollet, from its soft leaves,

Inula dysenterica, L.

Muscovy, or Musk, from its odour,

Erodium moschatum, L'Her.

Mushroon, Fr. mouscheron, at prescnt spelt mousseron, it name applied to several specics of Agaricus, and derived by Diez from mousse, moss, with which it is diffecult to sce how mushrooms are connected. Onc of the most conspicunus of the genus, the A. muscarius, is used for the destruction of flies, mousches, and as Albertus Magnus says (1. vii. 345) :

"Vocatur fungus musrarum, eo quod in lacte pulverizatus interficit muscas."

and this secms to be the real source of the word, which, by a singular caprice of language, has heen transferred from this poisonous species to mean, in the popular acceptation of it, the wholesome kinds exclusively. Agaricus, L.

Misk Orchis, from its scent,

Herminium monorchis, RB.

Musk Thistle, from its scent, Carduus nutans, L.

Mustard, It. mustarda, which according to Diez, Brachet, and Littré is derived from L. mustum, new wine, which they say is used in preparing it,

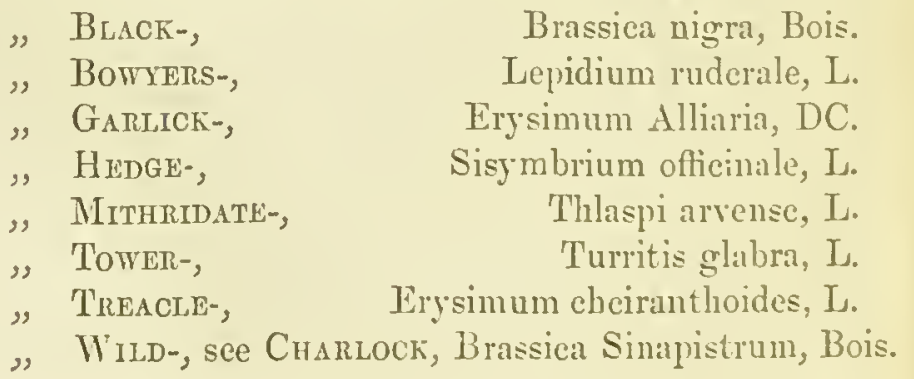

Brassica alba, Bnis. Brassica nigra, Bois. 
Mype, Wcl. maip, Gael. neip, given in Gerarde (p. s71) as a name of the parsnip, a corruption of L. napus, and properly meaning the turnip,

Brassica Rapa, L.

MYretee, It. mirtillo, dim. of mirto, L. myrtus, Gr. ниртоऽ,

Myrtus communis, L.

NaicwonT, perhaps more correctly Agnail-wort, the whitlow-grass, from its supposed curative powers in cases of agnail, Draba verna, L. and Saxifraga tridactylites, L.

NaKed Ladies, G. nakte jungfer, from the pink flowers rising naked from the earth, the mcadow saffron,

Colchicum autumnale, L.

Nancy Pretry, sec None-so-pretrty, the London pride, Saxifraga umbrosa, L.

NAP-AT-Noox, from its flowers closing at midday, the goat's beard,

Tragopogon porrifolius, $\mathrm{L}$.

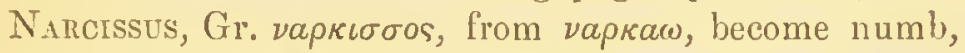
related to Skr. nark, hell, so called from the torpidity caused by the odour of the flower, as remarked by Plutareh,

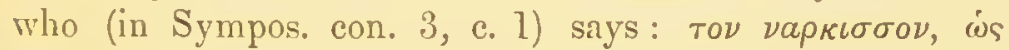

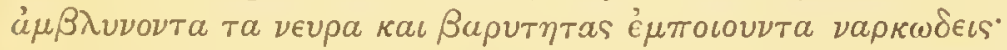

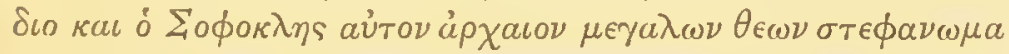

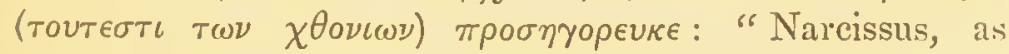
blunting the nerves, and causing Narentic heaviness: wherefore also Sophocles called it the ancient chaplet of the Great (that is the Infernal) gods." The passage is quoted from an exquisite chorus of the Edipus at Colonos,

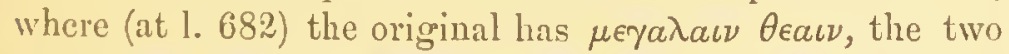
great goddesses, meaning Ceres and Proserpine. The epithet which the poct herc applies to the narcissus, $к a \lambda_{l}$ Borpus, finely clustered, suggests that he meant the hyacinth, a plant which, from its heavy odour and dark colour, was more likely than the one we now eall narcissus to have becn consecrated to those deitics. Plutarch adds that " those who are numbed with death should very fittingly 
be crowned with a benumbing flower." The crincidence of the name narcissus with the Skr. nark indicates some very ancicnt traditionary connexion of Greek with Asiatic mythology. Ovid, who undoubtedly means onc of the jlants which still bear this name, represents it as haring locen so called after a youth who pincd away for lore of his own image reflected in a pool of water; an instance, among many more, of a legend written to a name; for as an old poct, Pamphilus, remarks, Proserpine was gathering Narcissi long before that youth was born. Narcissus, L.

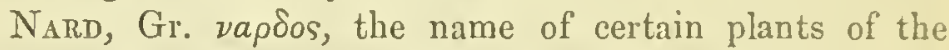
valerian tribe, that were formerly, and are still, much used in Asiatic harems, and valued for their scent,

$$
\text { Valeriana, L. }
$$

NAVEL-wort, from the shape of its leaf,

Cotyledon Umbilicus, L.

NAVEw, Fr. naveau, from napellus, dim. of L. napus, the rape,

Brassica Napus, I.

NECKWEED, a cant term for hemp, as furnishing halters for the necks of criminals,

Cannabis sativa, $\mathrm{L}$.

Nectarine, It. nettarino, dim. of nettare, L. nectar,

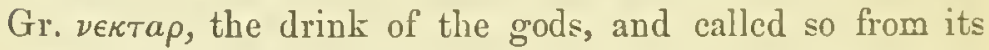
flavour, Amygdalus persica, var. lrevis, L.

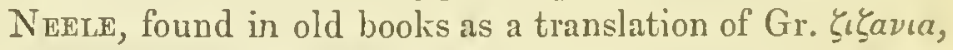
and equivalent to cockle or darnel, Fr. nielle, L. nigella, blackish, once used to mean weeds generally, but in later works restricted to the larger ray grass.

"Frumentis nocuam lolium Grecus rocat herbam, Quam nostri dicunt vulgari more nigellam." Macer, c. 64. Lolium temulentum, $\mathrm{L}$.

NeEd te Forze, from its delicate spines,

Genista anglica, L.

NEP or Neppe, contracted from L. nepeta, the cat-mint, Nepeta cataria, L.

Nettle, A.S. and Du. netel, Da. naelde, Sw. nactlo, 
G. nessel, the instrumental form of net, the passive participle of $n e$, a verb common to most of the Ind-European langrugges in the scnse of "spin" and "sew," Gr. $\nu \epsilon \epsilon \iota \nu$, L. ne-re, G. nä-hen, Skr. nah, bind. Nettle would seem to have meant primarily that with which one sews. Applied to the plant now called so, it indicates that this supplied the thread used in former times by the Germanic and Scandinavian nations, which we know as a fact to have been the case in Scotland in the seventeenth century. Westmacott says (p. 76) : "Scotch cloth is only the housewifery of the nettle." In Friesland also it has becn used till a late period. Flax and hemp bear southern names, and werc introduced into the north to replace it.

Urtica, L. , BeE-, Galeopsis versicolor, Curt.

Netrle, Dead-, or Blind-, Lamium, L.

" HeDGe-, from its nettle-like leaves and place of growth, more properly Hedge Dead-nettle,

$$
\text { Stachys sylvatica, } \mathrm{L} \text {. }
$$

Hemp-,

Galeopsis, L.

" Rovax-, from being found abundantly about Romuey in Kent, and the report that "Roman soldiers brought the seed with them, and sowed it there for their own use, to rub and chaf'e their limbs, when through extreme cold they should be stiffe and benummed; having been told that the climate of Britain was so cold, that it was not to be cndured without some friction or rubbing, to warm their blocds and to stir up natural heat." Parkinson (Th. Bot. p. 44.]). Lyte's explanation of this and other applications of the term "Roman" is more probable. "It is a straunge herbe, and not common in the countrey, and they do call al such straunge herbes as be unknowen of the common people, Romish or Romayne herbes, although the same be brought from Norweigh." Du. Roomsche netel, Fr. ortic romaine.

Urtica pilulifera, L.

Nigirtshade, A.S. niht-scada, O.H.G. naht-scato, from 
its officinal Lat. name solutrum, which is derived, as an instrumental noun, from L. solari, soothe, as aratrum from arare, and means "anodync." Under this form we find it in the Ort. San. (c. 349); and Matthioli, in speaking of the Belladonna (c. 59), describes it as "eam plantam quarn herbariorum vulgus solatrum majus nominut." This word solatrum has been mistaken for solem atrum, a black sun, an eelipse, a shade as of night.

" BittersweET-,

" Deadly-,

"Enchaster's-,

"Woody-: the bittersweet.

Ninety-Knot, see Knot-grass and Centinode.

Nipple-wort, Fr. herbe aux mamelles, from its use in cases of sore nipple, Lapsana communis, L.

Nit-GRass, from its little nit-like flowers, a translation of its L. specific name, lendigerum,

Gastridium lendigerum, L.

None-so-Pretty, or Nancy-PRetTy, the London pride, terms that seem to allude to the celebrated Nancy Dawson, of whom the song says :

"Of all the girls in our town, \&c., There's none like Nancy Dawson."

Saxifraga umbrosa, L.

Nonsuch, "a name conferred upon it from its supposed superiority as fodder." Smith in Eng. Bot.

Medicago lupulina, L. in Gerarde and Parkinson applied to the scarlet lychnis,

Lychnis chalcedonica, L.

NoON-Flower, or NoON-TIDE, from its closing at midday, and marking the hour of noon, the goat's beard,

Tragopogon pratensis, $\mathrm{L}$.

Noops, i.e. knops, A.S. cncep, a button, a name of the cloudberry used on the Eastern Border,

Rubus Chammenorus, L. 
Nosebleed, the yarrow, from its having been put into the nose, as we learn from Gerarde, to cause bleeding and to cure the megrim, and also from its being used as a means of testing a lover's fidelity. Forby in his East Anglia (p. 4.24) tells us that in that part of England a girl will tickle the inside of the nostril with a leaf of this plant, saying,

"Yarroway, yarroway, bear a white blow;

If my love love me, my nose will bleed now."

Parkinson (Th. Bot. p. 695) says that "it is called of some Nose-bleede from malking the nose bleede, if it be put into it, but assuredly it will stay the bleeding of it." This application of the yarrow, and all the superstitions connected with it, have arisen, as in so many other instances, from the medicval herbalists having been misled by a name, and taken one plant for another. Isidore (c. ix.) in speaking of a polygonum, but meaning by that name a horse-tail, says that it was called herba sanguinaria, from its being used to make the nose bleed. Apuleins calls the horsetail millefolium, and this term millefolium was subsequently transferred to the yarrow, which by this blunder acquired the names of Ilerba sangninaria and Nose bleed, and with the names the remedial charncter of the horse-tail, and its superstitious appliances. See Samguinary.

Achillæa Millefolium, L.

Nostoc, some alien word, the name of a genus of Algre. so called. Scc Fallen Stars. Nostoc commune, Ag.

Nut, A.S. hnut, Ic. hnitt, Sw. nolt, Da. nödd, G. nuss, L. nux, words connected with knit, linot, knopf, knob, implying a hard round lump.
„Chest-,
Castanea vesea, DC.
" Eartir-, or Pig-, or Jur-, or Hog-,
Bunium flexuosum, With.
" Frexcri-, the walnut,
" HazEL-, or WOOD-,
"W WL-, or WelsiI-, Juglans regia, L. Corylus Avellana, L. Juglans regia, L. 
OaK, A.S. ac, rec, Seot. aik, O.N. cik, Sw. el, Da.ey, Ic. eyk, L.G. eek and eik, G. ciche, O.H.G. eih, the $h$ having a gruttural sound. All these words refer to the fruit of the tree, the acorn, from whieh, as its most uscful product, the onk took its name. "During the Anglo-Saxon rule," says Selby, p. 227, "and even for some time after the Conquest, oak forests were eliefly ralued for the fattening of swine. Laws relating to pannage, or the fattening of logs in the forest, were enaeted during the Heptarehy; and by Ina's statutes any person wantonly injuring or destroying an oak-tree was muleted in a fine varying aceording to its sizc, or the quantity of mast it produced." Quereus, L.

" HoLm-, from its leaves being evergreen and somewhat like the upper leaves of holly, Quereus Ilex, L.

Oak of Cappadocia, or -of Jerusalems, from a fancied resemblanee of its leaf to that of an oak, and its eoming from a foreign country, Chenopodium ambrosioides, L.

OAK-FERN, of old herbals, from its frequent oceurrence upon the trunks of oak trees, Polypodium vulgare, L.

", of modern botanists, for reason unknown,

Polypodium Dryopteris, L.

$\mathrm{O}_{A T}$, A.S. ata, a word that seems originally to have meant "food," the O.N. ata, and Lat. esca, for ellca or etca, and derived from words signifying "eat," A.S. etan, Lat. edlere, from an aneient root, the Skr. ad, and applied to the oat cxclusively, as being onee the ehief food of the north of Europe. With this word ata is etymologieally eonneeted, and indeed, identical, G. aas, a earease, the term haring, apparently, been adopted, in the former sense by an agrieultural, and in the latter by a carnirorous, a shepherd or hunter tribe of the Germanie race: an evidenee, as far as it goes, that we must not assume our various dialects to have originated simultaneously from any one eommon tonguc, or in any one distriet.

Avena sativa, L.

WILD-, Arena fatua, L. 
OAT-Grass, a farmer's term, aeeording to Martyn in Fl. Rust., but eertainly not a common one, for the lobgrass,

Bromus mollis, L.

Ofbit, in Turner Ofbrten, for bitten-off', the Devil's bit, from the appearanee of the root, Scabiosa sueeisa, L.

OrL-SEED, from oil being made from it,

Camelina sativa, L.

OLD-MAN, southernwood, from its use as reeommended by Pliny (1. xxi. c. 2l), and as explained in the line of Maeer, e. ii. :

"Hæc etiam venerem, pulvino subdita tantum, Incitat."

Artemisia Abrotanum, L.

OLD-MAN'S-BEARD, from its long white feathery awns, the traveller's joy,

Clematis Vitalba, L.

ONE-berry, from its one eentral fruit, the trulove, Paris quadrifolia, $\mathrm{L}$.

ONE-BLADE, from its barren stalk having only one leaf. Its Latin speeific name implying "two-leaved" refers to the flowering stalk. Maianthemum bifolium, DC.

Onion, Fr. oignon, in a Wyeliffite version of Num. xi. 5, uniowns, from L. wnio, some speeies of it mentioned by Columella,

Allium Cepa, L.

WELsH-, not from Wales, but the G. wälsch, foreign, the plant having been introduced through Germany from Siberia,

Allium fistulosum, L.

Orach, formerly Arach, in. Pr. Pm. Arage, in MS. Harl. 979, Arasches, Fr. arroche, a word that Menage, Diez, and Littré derive from L. atriplice. Its Gr. name $\chi \rho v \sigma o \lambda a \chi a \nu o \nu$, golden herb, suggests a more probable explanation of it in a presumed M.Lat. aurago, formed from aurum, gold, by the addition to it of ago, wort, as in plantago, lappago, plumbago, solidago, ete., and this word aurago would beeome in French arroche, as borago bourroche. At the same 
time its use in the eure of jaundice, aurugo, may lave fixed npon the plant the name of the disease.

"Alriplicem tritam cum nitro, melle, et aceto, Dicunt appositam calidam sedare podagram: Irtericis dicitque Galenus tollere morbum Illius semen cum vino sæpius haustum."

Macer, c. xxviii. 1. 7. Atriplex hortensis, $\mathrm{L}$.

„Stinking-, or Dog's-, from its foul smcll,

Chenopodium Vulvaria, L.

Orchanet, from the French. See Alcavet.

ORCHARD-GRASS, from its growing in orchards under the drip of trees,

Dactylis glomerata, L.

Orchal, Orchel, Orchil, or Archal, a lichen used in dyeing, so called after Federigo Rucellai, or Oricellari, who about the year 1300 first introduced it. Höfer, Hist. de la chimie, t. 1. p. 471 .

Orcheston Grass, see Krot-Grass,

Agrostis stolonifera, L.

Orснгs, Gr. ó $\chi \iota s$, from its double tubers,

, BEE-, from the resemblance of its flowers to a bee,

Ophrys apifera, L.

"BoG-,

, Butrerfly-,

"Drone-,

, FLY-,

, Frog-,

"Green-man-,

, Green Musk-,

"HAND-,

" Lizard-,

, MAN-,

, Military-,

,MONKEY-,

"MUsk-,
Malaxis paludosa, Sw. Habenaria bifolia, RB.

Ophrys fucifera, Sm. Ophrys muscifera, Huds. Habenaria viridis, $R B$. Accras anthropophora, RB. Herminium monorchis, RB.

Orchis maculata, L.

Orchis hircina, Scop. Aceras antbropophora, RB. Orchis militaris, L. Orchis teplurosanthos, Vill. Herminium monorehis, RB. 
, SPIDER-,

Oplurys aranifera, Hud. and arachnites, Willd.

Organi, or Oran, marjoram, from L. origanum, Gr. ò also the penny-royal, Origanum vulgare, L. Mentha Pulegium, L.

Orpixe, Fr. orpin, eontraeted from orpiment, L. anripigmentum, gold pigment, a sulpliuret of arsenic, a name given in old works to certain yellow-flowered specics of the genus, but perversely enough, transferred of late to almost the only European one that has pink flowers,

$$
\text { Sedum Telcphium, Is. }
$$

Orrice, either from its officinal Latin name, Acorus Dioscoridis, or from Ireos, (sc. radix) by transposition of the vowels, or very probably from some confusion between these two words, ireos and acorns; since the roots of two different species of Iris were known as Acorus falsus or adulterinus, and sold for those of Aenrus Calamus, L. (Bauhin's Pinax. p. 34.) It cannot be derived, as in our dictionaries, from Iris, the initial $I$ of which could not have beeome $O$, and could scarccly have remained unaspirated. At present it means the Florentine Iris, but is used in older works as a generic name, and in Cotgrave, and old German herbals, applied as Wild Ireos, to the water flower de luce, and to the stiuking gladdon. Iris, $\mathrm{L}$.

Osier, Mr. osier, M.Lat. oseria, whenee osevetum, a withy-bed, from a Celtic word meaning water, or ooze, that has given its name to the Oise in France, and to screral rivers in England, spelt aecording to the dialect of the district, Ouse, Osc, Use, or Ise, and which in M.Lat. would have made Osa, whenee an adjective osaria, aqueous, and osier.

Salix viminalis, L.

Osuund, Osmond royal, or Osmund the waternan, apparently a corruption of G. gross mons-kraut, greater moon-wort, representing its ancient officinal name lunaria mujor. There are other derivations of it, such as that by 
Beekmann, from the name of some person; hy Nemnich, on the authority of Houttnyn, from os, mouth, and mundare, eleanse; by others from os, bone, and mundare, cleanse. The Waterman would seem to be its Flemish name, Watervarn. The Royal refers, we are told by Lobel (Kruydb. i. p. 991), to its great and exeellent virtues; but more probably to its stately habit. Osmunda regalis, $\mathrm{L}$.

Osterick, M.Lat. ostriacum, apparently a corruption of L. aristolochia, a name transferred to it from another plant, Polygonum Bistorta, L.

Our Lady's Bedstraw, etc. See Lady's.

OWLER, a corruption of Aller, the alder tree.

Ox-EYE, the great daisy, a translation of L. buphlhal $m u s$, Gr. $\beta o v \phi \theta a \lambda \mu o \nu$, a name now appropriated to a different genus, Chrysanthemum Leucanthemum, L.

Ox-HEEL, or more properly Ox-HEAL, A.S., oxnalil, from its being used in settering oxen. See SETtermort.

Helleborus foetidus, L.

Oxu.IP, A.S., oxan-slippe, a word that, like Cowslip, is of very uneertain derivation. O. Coekayne (in Leech. ii. p. 378) suggests that the seeond syllable may be slyppa, a soft viseid mass, but leaves unexplained what this has to do with the plant. Primula veris eauleseens, L. elatior, Jacq.

OX-TONGUE, from the shape and roughness of its leaf, Helminthia eehioides, Gärt.

Oyster-GReEN, a sea-weed, so named from its bright green tint, and its being frequently found attached to the oyster,

Ulva laetuca, L.

PadDock-PIPes, in Cotgrave TOAD-PIPEs, from its straight hollow pipe-like stalks, and growth in mud, where toads haunt, the horse-tail,

Equisetum limosum, L.

Paddock-stools, in Topsell Padstoole, Du. paddc-stoel, toad-stool, from their resemblanee to the tripods called joint-stools, and the notion that toads sit upon them. (See TOADSTOOL).

Boletus and Agarieus. 
Padelion, Fr. pas de lion, from the resemblanee of its leaf to the impress of a lion's foot, the lady's mantle,

Alchemilla vulgaris, $\mathrm{L}$.

Paigle, Pagle, Pagel, Peagle, Pegyli, and Pygrt, a name that is now seareely heard exeept in the Eastern eounties, and usually assigned to the eowslip, but by Ray and Moore to the Ranunenlus bulbosus. It is a word of extremely obseure and disputed origin. If we were sure that in the first plaee it meant the Ranunculus, there would be renson to think that it eame from Du. spiegel, a mirror, and referred to an amusement of ehildren to reflect the flower upon the ehin of their playmates to see whether they love butter. This I am inelined to think is its simple, but most probable, origin. Of the transferenee of names from one plant to another we have examples enough. Most of the dietionaries derive it from paralysis; Latham from $\mathrm{F}$. épingle, a pin, in allusion to its pin-shaped pistil; Forby, strangely enough, from A.S. paelb, a die-plant, a purple robe; Forster, in Perennial Calendar, p. 19l, says that it "evidently signifies pratingale, from prata, meadows, where it delighteth to grow." An East Anglian eorrespondent informs me that paigle means a spangle. In Flemish pegel is a gauge.

Primula veris, $\mathrm{L}$.

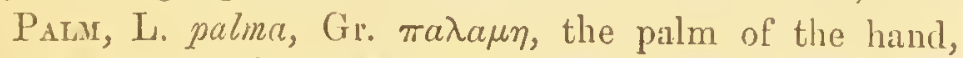
from the shape of the leaf in the species most familiar to Greek and Latin writers, the dwarf palm of the sonth of Europe. The name is given in England to the sallow with its eatkins in flower, from its branches having formerly been carried in proeessions, and strown on the road the Sunday next before Easter, in imitation of the palm leaves that were strown before Jesus on his entry into Jerusalem. A representative of the Eastern tree was required, and these golden tassels presented themselves at preeisely the right season. Branches of the yew tree, on aceount of its leuves being green at this season, were also used. In an 
old sermon on Palm Sunday, quoted by Hampson (ii. 300), the aecount of it is as follows: "pan Thu yode towerde Jerusalcm, and pe pepul brokon brawnehes of olyfe and of palme and keston in pe way, \&e., but for encheson we have non olyfe pat bereth grene leves, we takion in stede of hit hew and palmes wyth, and bercth abowte in proeession." (Cott. MS. Claud. A. 11. fo. 52.) This was the ancient usage in Scotland, as deseribed by Sir Walter Scott in his Castle Dangerous (eh. ix.): "Several of the Seottish pcople, bearing willow branehes, or those of yew, to represent the palms which were the symbol of the day [Palm Sunday] were wandering in the ehurehyard." So also in The fair maid of Perth (vol, ii. eh. xvii.): "Bearing branehes of yew in their hands as the readiest substitute for palm boughs." This was the eustom in East Kent, according to Evelyn's Sylva; in Dorsetshire, Notes and Queries, (3 S. vii. p. 364); and in Ireland; and the yew-tree which, as well as the willow, was popularly called "Palm," was planted in churehyards to supply boughs for these oceasions. Salix eaprea, L., and Taxus baceata, L.

Palsy-wort, L. Merba paralyseos, from its supposed power to cure the palsy, the eowslip, Primula veris, L.

Pance or Paunce, sce Pansy.

PaNICK-GRass, L. panicum, which Pliny says was "a panieulis dictum," so ealled from its panieles. The word seems to be formed from panus, a head of millet, and to be connected with panis, bread, from an ancient root pa, feed, retained in pa-sco, pa-bulum, and pa-ter. See Bopp. Comp. Gram. p. 1164.

Panicum, L.

Pansy, or Paunce, Fr. pensée, thought, onee ealled menues pensées, It. pensieri menuti, idle thoughts, G. unnïtze sorge. Dr. Johnson and Talbot would derive the name from L. panacea, but the plant has never been called so, nor regarded as a panacea. Its habit of eoquettishly hanging its head, and half hiding its face, as well as 
some fancied resemblances in the throat of the corolla, lias led to many quaint names in our own, and in foreign languages: "Cull me-," or "Cuddle me to you," "Love and idle," "Live in idleness," or "Love in idleness," a line, perhaps, of some song or poem, "To live and love in idleness," but originally, it would seem, "Love in idle," that is, "in vain," and in Lobel, "Love in idle Pances," "Tittle my fancy," "Kiss me, cre I rise," "Jump up and kiss me," "Kiss me at the garden gatc," "Pink of my John," and several more of the same amatory character. From its three colours combined in one flower, it is called "Herb Trinity," and "Three faces under a hood;" from confusion with the wallfower, "Heartsease ;" and from M. Lat. viola flammea, "Flame flower." There is no plant that has obtained so many names, and curious sobriqucts. Viola tricolor, L.

Paris, see Herb Paris.

Park-leaves, a name that seems, like its Danish, Swedish, and Norwegian synonym, pirkum or perkum, to

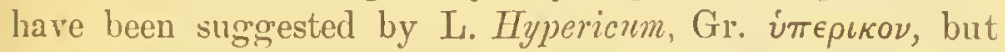
taken in the sense of perked or pricked leaves, from those of the commonest species of the genus, H. pcrforatum, L. being so dotted with resinous deposits, as to look as if they were pricked all over; a charactcr not observable in that to which the namc of Park-leaf is now restricted. Its Frcich synonym, parcoeur, by heart, seems, like the English name, to have been suggested by the Latin through an accidental coincidence of sound.

H. Androsæmum, L.

Parsassus-grass, a plant supposed to be one described by Dioscorides as growing on Mount Parnassus,

Parnassia palustris, L.

PArsley, spelt in the Grete Herball Percely, Fr. persil, L. petraselinum, from Gr. $\pi \in \tau \rho o s$, rock, and $\sigma \in \lambda \iota \nu 0 \nu$, some umbelliferous plant,

"Bastard-, or Bur-,

P. sativum, Koch.

Caucalis daucoides, $\mathrm{L}$. 


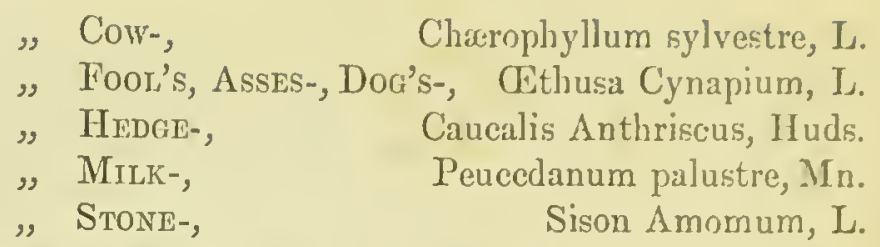

PARSleY-k'ERN, from the resemblance of its fronds to parslcy leaves,

Cryptogramma crispa, $\mathrm{RB}$.

Parsley-pient, or Parsley-Break-stone, Fr. perce-pierre, of percer, pierce, and pierre, stone, from its bcing used in cases of stone in the bladder, and so called, according to $T$. Coles (Ad. in Ed. ch. 222), "from its cminent faculties to that purpose,"

Alchemilla arvensis, Sm.

Parsnip, or, as it is spelt in old herbals, PASsep and Pastnir, from L. pastinaca, by change of $c$ to $p$,

Pastinaca sativa, $\mathrm{L}$.

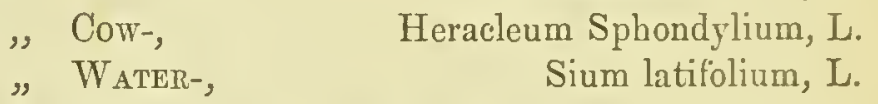

Pasque- or Passe-Flower, Fr. pasques, Gr. $\pi a \sigma \chi a$, Heb. pesach, a crossing over, from its blossoming at Easter, that in old works was called Pask; as in Robert of Brunne, p. 263 :

"Fro gole to pe pask, werred Sir Edward,"

Anemone Pulsatilla, L.

Passenage, the garden cress, from the French, and derived by Littré from passer used transitively and rage, madness, and called so, and also chasserage, from its supposed power of driving away hydrophobia,

\section{Lepidium, L.}

Passions, or Patience, a dock so called, apparently, from the Italian name under which it was introduced from the South, Lapazio, a corruption of $\mathrm{L}$. lapathum, having bcen mistaken for la Passio, the Passion of Jesus Christ, Rumex Patientia, L.

Paul's Butony, a name given to it by Turner, as being 
the plant described as a betony by Paul Agineta,

Veronica serpyllifolia, L.

Pawnck, in Spenser, the Pansy.

PEA, in old works PEAse, a word that has either arisen from Fr. pois, pronounced, as it used to be, pay, or from the old form pease being, like cerise, a cherry, mistaken for a plural. The Lat. pisum, from which it is derived, means brayed in a mortar, pinsun, or, as it is spelt in Apuleius, pisatum, Gr. $\pi \iota \sigma o s$, from Skr. pish, bray, whence peschana, a quern or handmill. Tusser makes the plural peason agreeably to a practice of ending the plural with $n$, when the singular ends with $\delta$, as e.g. oxen, housen, hosen, from ox, housc, hose.

Chick-,
" Chickling-,
EverlastinG-,
" Heath-,
Sweet-,
"Wood-,

Pisum sativum, L. Cicer arietinum, $\mathrm{L}$. Lathyrus, L. Lathyrus latifolius, L. Orobus tuberosus, L. Lathyrus odoratus, L. Orobus tuberosus, L.

Peach, in old works spelt Peske, Peesk, Peshe, and Peche, O.Fr. pesche, L. persica, as in Pliny (H.N. b. xv. c. 13), a proof, as he remarks, that this fruit was introduced from Persia, Amygdalus Pcrsica, W.

PEdCH-wort, from the resemblance of its leaves to those of the peach, Polygonum Persicaria, L.

$\mathrm{PEAR}_{2}$ a foreign word adopted from the Southern into the Germanic languages, It. and Sp. pera, Fr. poire, probably once pronounced paire, from L. pyrus,

\section{Pyrus communis, L.}

Pearl-plant, from its smooth hard pearly seed, the gromwell, Lithospermum officinalc, L.

Pearl-grass, from its glittering panicles,

Briza maxima, L.

Peart-Tort, from its being used to cure a disense of the eyc called pearl,

Sagina, I. 
Peaseling, an inferior Pea, (compare Chickling, Vetchling, Crambling), Orobus, I.

Pegroots, (Dale, p. 177) the green hellebore, from its roots being used by cattle doctors in the operation of pegging or settering. See StrTeiworr.

Helleborus viridis, L.

Pell-a-mountain, or Pency Mountain, corruptions of serpyllum montanum, hill thyme, Thymus Serpyllurn, L.

Pellitory, or Paritory, of the wall, L. parietaria, from paries, a house-wall, into which this weed usually grows, $\quad$ Parietaria officinalis, L.

Pelditory, or Peldeter of Spata, Sp. pelitre, L. pyrethrum, Gr. $\pi \nu \rho \in \theta \rho o \nu$, "by reason of his hot and fiery taste," says Gerarde, p. 758. The term Pellitory of Spain seems merely to refer to its being the plant called so in Spain, and not to its being brought thence.

Anacyclus Pyrethrum, DC.

PENNy-cress, from its round flat silicules, resembling silver pennies, Thlaspi arvense, L.

Penny-grass, from its round seeds like silver pennies, Rhinanthus Crista galli, L.

Penny-rot, in Lyte Penny-grass, from its character of giving sleep the rot, and its small round leaves,

\section{Hydrocotyle vulgaris, $\mathrm{L}$.}

Penny-Royal, from L. pulein regium, through $\mathrm{Du}$. poley, in the old herbals called puliol royal; its Latin name being derived from its supposed efficacy in destroying fleas, pulices, Pliny (H. N. b. xx. c. 54).

Mentha Pulegium, L.

PENNY-WoRT, from its round leaves,

Linaria Cymbalaria, Is.

$\begin{array}{ll}\text { MARSH-, } & \text { Hydrocotyle vulgaris, L. } \\ \text { WALL-, } & \text { Cotyledon Umbilicus, L. }\end{array}$

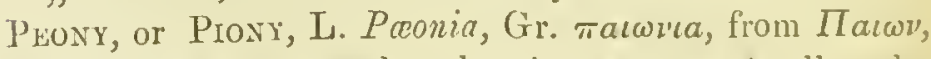
a god of physic, supposed to be the same as Apollo, who 
healed the gods Ares and Hades of their wounds (Homer, Il. bk. v. 1. 4.01 and S99), Pæonia corallina, Retz.

Pepper, L. piper, Gr. $\pi \iota \pi \epsilon \rho \iota$, Skr. pippali.

"WALL-, from its biting taste, and place of growtl, the stone-crop,

Sedum acre, L. and also

$$
\text { W } \text { ATER-, }
$$

Pepper-crop, a cyme or head of flowers with the pungent taste of pepper, the stone-crop, Sedum acre, L.

Pepper-grass, a plant with lincar grass-like leaves, and pepper-corn-like pellets of inflorescence,

Pilularia globulifera, $\mathrm{L}$.

Pepper-ment,

Pepper-Saximrage,

PEPPER-worT, from their acrid taste, the cresses, but more particularly

Lepidium latifolium, L.

Percepier, Fr. percepierre, pierce-stone, from its supposed lithontriptic virtues,

Alchemilla arvensis, Sm.

Periwinkle, in Chancer and other old pocts spelt Perityke and Pervenke, M. Lat. pervincula, dim. of L. pervinca, from per, about, and vincire, bind, this plant having been used for chaplets, as in the Ballad against the Scots, 1. $12: 3$ :

"A garlande of pervenke set on his heved." Ritson, vol.i. p. 33.

Vinca major, and minor; L.

Persian Willow, oftener called French Willow, although really an American plant, from the resemblance of its leaves to willow leaves, and its foreign origin,

\section{Persicaria, sec Peach-wort.}

Epilobium angustifolium, L.

Pestilence-weed, G. pestilenz-wurz, the butterbur coltsfoot, from its having been formerly, as Lyte tells us, (b. i., c. 13) of great repute as "a sovereign medicine against the plague and pestilent fevers ;" for, as the Ortus Sanitatis more explicitly declares (c. cexlv.); "Der safft von 
discm kraute, gemisehet met cssig und rauten-safft, yegliclis gleieh vil, und dis gretruncken des abents auff ein löffel foll, maehet sere schwitzen, und treibet mit dem schweiss auss dic pestilcnz."

Tussilago Petasites, I.

Petrigree or Petrigrue, Fr. petit, little, and greou, holly, the butcher's broom, so called from its prickly leaves,

Ruscus aculeatus, L'Her.

Petty-mullein, the eowslip, its name in old herbals, as translated from L. verbasculum, this plant baving been regarded as a small speeies of verbascum or mullein,

Primula veris, L.

PetTy-whin, a small prickly shrub, a name giren in Lyte's Herbal to the restharrow, but by later botanists to the needle-furze,

Genista angliea, L.

PEWTER-WORT, from its being used to clean perrter vesscls,

Equisetum hyemale, L.

Pheasant's Eye, from its bright red corolla and dark centre,

Adonis autumnalis, L.

Pick-needle, see Pink-needle, and Powke-needle,

Erodium moschatum, L.

ProK-Purse, from its robbing the farmer by stealing the goodness of his land; a name that in some counties is given to the spurry, but seems to have been assigned to the shepherd's pouch more especially, on account of the number of little purses that it displays, its purse-like silicles; $\quad$ Capsella Bursa pastoris, L.

Pigeon's-grass, Gr. $\pi \epsilon p \iota \sigma \tau \epsilon \rho \epsilon \omega$, a place for pigeons, a name given to it, according to Galen, as quoted by Matthioli (1. iv. c. 56), from pigcons frequenting it: "quod in ea peristeræ, hoc est columbæ, versentur." So also the Medical MS. Sloane, 1571, 1.699:

And gyt sayth mayster Macrobius,

Gyf yt be cast in at duffe hows,

Alle the duffys ther abowte

Schulle gedyr theder on a rorte.

Verbena officinalis, L. 
Pigeon's pea, Fr. pois-pigeon, Ervum Ervilia, L.

PIG-NUT, from its tubers being a favourite food of pigs, and resembling nuts in size and flavour,

Bunium flexuosum, With.

Pig-Weed, from its being supposed to be fatal to swine, see Sowbane,

Chenopodium rubrum, L.

Piggesnie, or, as in MS. Harl. 7334, Piggesneyghe, a word that occurs in a line of Chaucer, applied to a lady, and associated with the primrose,

\section{"A primerole, a piggesneyghe." Mill. T. 82.}

And in the ancient song, My suete swetyng, in Ritson's collection (vol. ii. p. 21) :

\section{"And love my pretty pygsnye."}

The commentators on Chaucer explain it, amusingly enough, as a "pig's eye." It seems to mean a "Whitsuntide pink," from L.G. Pingsten, G. Pfingst, and eye, Fr. oeillet, L. ocellus, the name of these flowers from the circular marking of their corolla. Pingst is shortened from Gr. $\pi \epsilon \nu \tau \eta \kappa о \sigma \tau \eta$, meaning the fiftieth day after Easter, and Pingsten-eye has bcen corrupted into Piggesnie.

Dianthus Caryophyllus, L.

Pile-wort, L. pila, a ball, in allusion to the small tubers on the roots, and its supposed efficacy, on the doctrine of signatures, as a remedial agent,

Ranunculus Ficaria, L.

Pill-conn, or Pild-conn, that is, peel-corn, from its grain separating from the chaff, Avena nuda, L.

Pill-wort, from its small globular involucres, L. pilula, dim. of pila, a ball,

Pilularia globulifera, L.

Pimpineld, or Pisipernele, Fr. pimprenelle, It. pimpinella, M. Lat, bipennella, from having sccondary little pinnæe, or feather-like lcaftcts; in old authors, as Evelyn 
in lis Aeetaria, and Lyte, the lurnet, of which the Italian proverb says :

"Linsalata non e bella Ove non e la I'impine-lla."

Poterium Sangruisorlua, L.

in modern works more generally

Pimpinella Saxifraga, Is.

" RED-, a plant entirely different from the above, as are the two following species, and in no way agreeing with the name as just explained, and why ealled so unlinown,

Anagallis arvensis, $\mathrm{L}$.

, WATER-,

Samolus Valerandi, L.

and in Lyte Veroniea Beceabunga, and V. Anagallis, L.

"YELLOW-,

Pin-Rlish,

Prne-T'ree, L. pinus, a word that J. Grimm eonsiders to be a eontraetion of picinus, pitehy, and others as related to Skr. pina, fat, L. pinguis, in allusion to its resinous seeretion. Isidore says that it was ealled so "ab acumine foliorum : pinum enim antiqui acutum nominabant" (from the sharp point of its leaves ; for picked was by the aneients called pinum).

Pinus, L.

"Ground-, from its terebinthinate odour and lowly

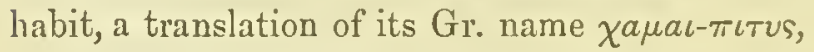

Ajuga ehamæpitys, L.

PINE-SAP, either from its sapping the pine, or growing from the juices of the pine, a modern term left by its author unexplained, Monotropa Hypopitys, L.

Pink, L. Germ. pingsten, Du. pintister, Thitsuntide, as in the first line of Reinelse de Vos,

"It gesehach up einen pinkstedacl,,"

"It happened on a Whitsunday,"

the season of flowering of one of its speeies, the Whitsuntide-gilliflower of old authors. The dietionaries derive it from a supposed Duteh word, pink, an eye; one, lowerer, that does not appear to have any suels meaning in that 
language. It is a curious accident, that a word, that originally meant "fiftieth," $\pi \epsilon \nu \tau \eta \kappa o \sigma \tau \eta$, should comc to be successively the name of a festival of the Church, of a flower, of an ornament in muslin called pinking, of a colour, and of a sword-stab. See Prggesnie.

Dianthus, L.

Cheddar-, or ClifF-, from its occurrence on Cheddar clifts,

D. casius, L.

Clove-, from its odour of cloves,

,"

Cushion, from its habit, DEPTFond-, from its place of growth in Gerarde's time,

Marden-, more properly, MEADow-, G. wiesennelle, from its place of growth, a confusion of maid and meanl,

D. deltoides, L.

Pink-NeEdle, from the rescmblance of its long tapering awns to the needle used in pinking, or making cyclet holes like pinks, in muslin,

Erodium moschatum and cicutarium, L.

Prink-weed, from the colour of the stems, the knot-grass, Polygonum aviculare, $\mathrm{L}$.

Pipe-tree, the lilac, from its branches having a large pith that is easily bored out to make pipe-sticks, whence also its Latin name from Gr. $\sigma \nu \rho \iota \gamma \xi$,

Syringa, L.

Pipewort,

Eriocaulon septangulare, L.

Pipperidge, or Piprage, red-pip, the barberry, Fr. pepin, a pip, and rouge, red, a name descriptive of the colour and character of its small juiceless fruit, which seems to be rather a pip than a berry,

Berberis vulgaris, $\mathrm{L}$.

Prssabed, the dandelion, its name in nearly all the languages of TVestern Europe, and called so, says Dalc, p. 83, "quia plus lotii derivat in vesicam, quam pueruli retinendo sunt, præsertim inter dormiendum, eoque tunc imprudentes et inviti stragula permingunt." Beckmann 
assigns the same reason. But it is questionable, whether a name so general could lave originally belongred to a plant that has never been an article of diet, and more probal,le, that it has been transferred to the dandelion from the salsify or the asphodel.

Taraxacum officinale, $L$.

Pixie-stools, a synonym of "toad-stools" and "paddoek-stools," the work of those elves,

\section{"whose pastime}

Is to make midnight mushrooms,"

and a name of some interest as shorring the identity of the king of the fairies, Puck, with the toad, Fries. pogge; for pixie is the feminine or diminutive of Puck, and the pisiestool the toad-stool. The name is in the Western eounties given to all suspieious mushrooms alike, but in printed books is generally assigned to the champignon. See TOADSTOOL.

Marasmius oreades, Fries.

Plaister-clover, from its trefoil leaves, and use in ointments, Melilotus offieinalis, L.

Plane, its Old Fr. and idiomatieally eorreet form, replaeed in Spenser (F. Q. I. i. 8) and in Milton (P. L. iv. 478), with Platane, L. platanus, Gr. $\pi \lambda a$ avos,

Platanus orientalis, and oceidentalis, $L$.

" Mock-, the syeamore, Acer pseudoplatanus, L.

Plantage, a name that oeeurs in Shakspeare's Troilus and Cressida, A. iii., Se. 2, with an allusion to a superstitious belief that seems to be due to a false derivation of the word, as planet-age, i.e. planet-wort:

"As true as steel, as plantage to the moon."

The poct probably meant not the plantain, but the moonwort.

Botryehium Lunaria, L.

Plantain, L. plantago, from planta, sole of the foot, and ago, whieh seems to have been used in plant-names with the sense of "wort," from the shape of the leaf in the larger species resembling a footstep, P. major, L. etc. 
" WATER-,

Alisma Plantago, L.

Plantain-Shoreweed, a weed of the plantain tribe found beside lakes and ponds, Littorella laeustris, L.

Plowaran's Allheal, see Clown's Allheal.

Plowman's Spikjanand, from the fragrant smell of the root, and its being supposed by Gerarde, p. 647, to be the

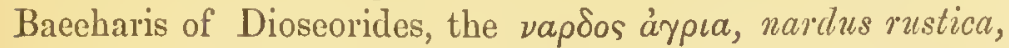
elown's nard, of other writers, Conyza squarrosa, L.

Plum, A.S. plum, L.G. prume, L. prunum, from some Asiatic name. In Cato's time the fruit was known to the Romans, but not the tree.

Prunus communis, Huds. var. domestiea, L.

Pole-ReEd, properly, as in Newton's Bible Herbal, and as it is still ealled in our Western counties, Poot-nEED, from its place of growth, Arundo Phragmites, L.

Pole-rush, Lyte, eh. lii., properly, as in our Western eounties, Pool-rush, see Bulnush.

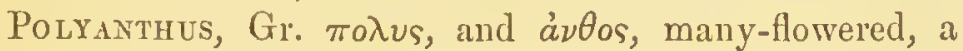
garden variety of the oxlip, Primula veris, L. elatior.

Poly-jountain, L. polium montanum,

Bartsia alpina, $\mathrm{L}$.

Polypody, Gr. $\pi o \lambda v s$, and $\pi o \delta \in s$, many feet, a name given to certain ferns with peetinate fronds, from the resemblanee of some of them to a seolopendirium,

Pojpion, see Pumpkin.

Polypodium, L.

Pondweed, from its growing in ponds,

Potamogeton, L.

" Horned-, Zannichellia, L.

Poor-man's Parmacetty, L. sperma ceti, whale's sperm, "the sovereignst remedy for bruises," a joke on the Latin name of the plant, Bursa, a purse, which to a poor man is

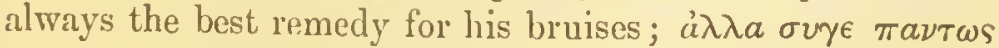

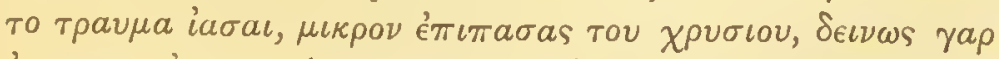

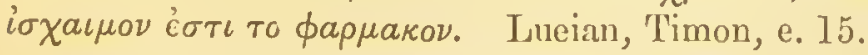

Capsella Bursa yastoris, L. 
Poor-anan's Pupper, Tseridium latifolium, Is.

Poor-Man's Treacre, garliek, a translation of Lat.

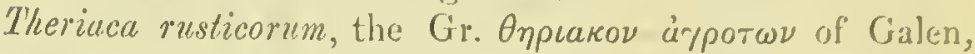
so ealled beeause it was supposed to he an antidote to animal poison, (Pliny, 1. xx. c. 23). See 'I'reacle Mistaru. In Arund. MS. 42, f. 15b, as quoted in Pr. P'm. (Way), p. 501, we read that juiec of garliek "fordop venym and poyson mygtily, and pat is pe skyle why it is ealled Triacle of uppelonde, or ellys homly folkys 'Triacle."

\section{Allium sativum, L.}

Poor-MaN's WEATHER-gLass, the red pimpernel, from its elosing its flowers before rain, whenee the proverb:

"No ear hath heard, no tongue can tell

The virtues of the Pimpernell."

\section{Anagallis arvensis, L.}

Poplar, Fr. peuplier, from L. popularia, adj. of populus, a word that seems to be identical with pepul, the name of the Indian Ficus religiosa, the leaves of which so elosely resemble those of the poplar, as in the varnished and pietured speeimens to be very eommonly taken for poplar leaves; a name that was probably brought westward to Europe by the early Asiatic colonists, and earried eastward into India, in connexion with some rcligious observances, Populus, L.

Poplar, Black-, in eontrast to the White poplar,

\section{P. nigra, L.}

" Lombardy-, from a perhaps mistaken belief that it came originally from the north of Italy,

$$
\text { P. fastigiata, Dsf. }
$$

"White-, or GreY-, from the eolour of the undersurface of its leaves, P. alba, L.

Pople, a name given in W. Turner's Libellus to the coinn coekile, Agrostemma Githago, L.

Poppy, A.S. papig, L. papaver,

"G G GREN-, or OpIUa-, or White-,

P. somniferum, L. 
" Horned-, from its long curved seed-pods,

Glaucium luteum, L.

„, Red-, or Cony-, or Field-,

P. Rhœas, L.

SEA-,

Glaucium luteum, L.

"Spatling-, from the froth called cuckoo-spittle so frequently found upon it, Silene inflata, L.

, Welsh-, from its occurrenec in Wales,

Meconopsis cambrica, L.

Potato, Sp. Batatas, the name of a tropical convolvulus, the so-called "Sweet-potato," injudiciously transferred to a very different plant, Solanum tuberosum, L.

Potherb, Whire-, the lamb's lettuce, in contrast to the Olus atrum, or Black potherb, Valcrianclla olitoria, L.

Poukenel, or Powke-needle, L. acus denonis, Devil's darning needle, from Pouke or Puck, Satan, in allusion to the long beaks of its seed-vessels, Scandix Pecten, L.

Pratling Parnell, a name that seems to imply a girl of suspicious character, who has let out scerets, or told tales to her own discredit, Saxifraga umbrosa, L.

Prickly Samphire, see Samphine.

Pricket, Fr. triacquette, dim. of triacque, and

Prick-Madar, Fr. trique-madame, for triacque madame, from L. theriaca, an anthelmintic medicine, anong the principal ingredients of which were stone-crops,

Sedum acre, album, and reflexum, L.

Prick-timber, or Prick-wood, from its being used to make skewcrs, shoemakers' pegs, and goads, which were formerly called pricks, G. pinnholtz, the spindle tree,

Evonymus curopæus, L.

Priest's Chown, from its bald receptacle, after the pappus has fallen from it, rescmbling the shorn heads of the Roman Catholic clergy, Taraxacum officinalc, Vill.

Priest's Pintle, G. pfaffen-pint, and pfaffen-zagel, Fr. vit le prestre, so called from the appcarance of the spadix, Arum maculatum, L. 
Primerole, in Chancer, (Mill. T. 1. 82, ) and Gower (b. vii,) from the Fr. primeverole, dim. of primavera, shortened from It. fior di prima vera. See Prumirose.

Primula veris, L. acaulis.

Primprint, or Prim, a name now given to the privet, but formerly to the primrose, from the $\mathrm{Fr}$. prime printemys, first spring, and exactly corresponding to the modern Fr. name of this flower, primeveree. In the middle ages, however, the primrose was called in Latin Ligustrum, as may be seen in a Nominale of the fifteenth century in Mayer and Wright's vocabularies, (p. 192 and p. 264, ) and several other lists, and so late as the seventeenth century in W. Coles's Adam in Eden, where he says of Ligustrum, "This herbe is called primrose. It is good to potage." But Ligustrum was used on the continent, and adopted by Turner, as the generic name of the Privet; and prim-print, as the English of Ligustrum, thus came to be transferred from the herb to the shrub.

Ligustrum vulgare, $\mathrm{L}$.

Primet, shortened from primprint, and correctly applied in the Grete Herball, ch. cccl., to the primrose,

\section{Primula veris, L.}

Primrose, from Pryme rolles, the name it bears in old books and MSS. The Grete Herball, ch. cccl., says, "It is called Pryme Rolles of pryme tyme, because it beareth the first floure in pryme tyme." It is also called so in Frere Randolph's catalogue. Chaucer and Gower write it in one word primerole. This little common plant affords a most extraordinary example of blundering. Primerole is an abbreviation of Fr. primeverole, It. primaverola, dim. of prima vera, from fior di prima vera, the first spring flower. Primerole, as an outlandish unintelligible word, was soon familiarized in to prime rolles, and this into primrose. This is explained in popular works as meaning the first rose of the spring, a name that never would have been given to a plant that in form and colour is so unlike a rose. But the 
rightful claimant of it, strange to say, is the daisy, which in the south of Europe is a common and conspicuous flower in early spring, while the primrose is an extrcmely rare one, and it is the daisy that bears the name in all the old books. See Fuehs, p. 145, where there is an excellent figure of it, titled primula veris; and the Ortus Sanitatis, (Ed. Angsb. 14S6,) ch. cecxxxiii., where we have a very good woodeut of a daisy titled " masslieben, Premula veris, Latine." Brunfelsius, (ed. 15:1,) speaking of the Herba paralysis, the cowslip, says, (p. 190,) expressly, "Sye würt von etlichen Doctores Primula veris genannt, das doch falseh ist wann Primula veris ist matsomen oder zeitlosen." Brunschwygk (b. ii. e. viii.) uses the same words. The Zeitlose is the daisy. Parkinson (Th. Bot. p. 531) assigns the name to both the daisy and the primrose. Matthioli (Ld. Frankf. 1586, p. 653) calls his Bellis major "Primo fiore maggiore, seu Fiore di prima vera, nonnullis Primula veris major," and figures the moon-daisy. His Bellis minor, which seems to be our daisy, he ealls "Primo fiore minore, Fior di primavera, Gallis Marguerites, Germanis Masslieben." At p. $\$ 93$ he figures the cowslip, and calls that also "Primula veris, Italis Fiore di primavera, Gallis primevere." But all the older writers, as the author of the Ortus Sanitatis, Brunschwygk, Brunsfels, Fuchs, Lonicerus, and their eotemporaries, with the single exception of Ruellius, assign the name to the daisy only. Primula veris, L. aeaulis. Scotland,

ScOTCH-, from its growth upon the mountains of Primula farinosa, L.

Primrose Peerless, a name now given to a narcissus, apparently transferred to it from a lady, the favourite of 'Thomas à Becket, of whom it is related by Bale, that "Holye Thomas would sumtyme for his pleasurc make a journcy of pylgrymage to the prymerose jeerlesse of Staffordc." Hampson (vol, i. p. 121). 'The term primerose was not unfrequently applied to ladies in the middlc ages. Sec Chaucer, (Mill. 'T. I. 82). Nareissus biflorus, Curt. 
Prince's Featuen, from its resemblance to that of the Prinee of Wales, Amarantus hypoehondriacus, $\mathrm{L}$.

Priver, in Tusser Privy, altered fiom Prymet, an ablureviation of Primprint, the primrose, through a confusion between this flower and the shrub, from the application to both of them by medieval writers of the Latin Ligustrum. See Primiprint.

Ligustrum vulgare, $\mathrm{L}$.

„BARREN-, from its want of the eonspieuous white flowers of the real privet, to which it eertainly bears no other resemblanee than in being an evergreen,

\section{Rhamnus Alaternus, L.}

Procession Flower, see Rogation Flower.

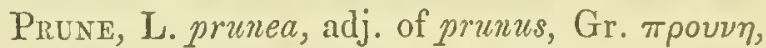

P. eommunis, Huds. var. domestiea, $L$.

Puckfists, from fist, G. feist, erepitus, and Puck, O.N. puki, who, in Pieree Plowman and other old works, seems to have been the same as Satan, but in later tales the king of the fairies, and given to coarse praetieal jokes. See Pixif Stools.

Lyeoperdon, L.

Pudding-GRass, pennyroyal, from its being used to make stuffings for meat, formerly called puddings, as in an Old Play, The Ordinary (Dodsley, vol. x. p. 229) :

"Let the Corporal

Come sweating under a breast of mutton, stuffed With Pudding."

R. Turner says (Bot. 1). 247), that it was espeeially "used in Hogrspuddings," which, aeeording to Halliwell, mere made of flour, eurrants, and spiee, and stuffed into the entrail of a hog. Mentha Pulegium, L.

PUFY-BALL, from its resemblanee to a powder puff, Lyeoperdon giganteum, Bat.

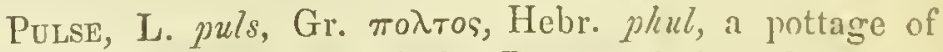
meal and peas, the food of the Romans before the introduetion of bread, and afterwards used to feed the saered ehieken, a term now eonfined to the fruit of Leguminosie. Pumpkin, or Poupion, Fr. prompon, whenee bumpkin, 
L. pepo, -onis, Gr. $\pi \epsilon \pi \omega \nu$, which was used in the samc sense; as, e.g. in Homer (Il. ii. 235), $\grave{\omega} \pi \epsilon \pi o \nu \epsilon s$, blockheads! and in the phrase $\pi \epsilon \pi o \nu o s$ $\mu a \lambda a \kappa \omega \tau \epsilon \rho o s$, softer than a pumpkin ; see Talbot in Eng. Etym. Cucurbita Pepo, L.

Purification Flower, the snowdrop, see Fair Maids of February.

Purple Loosestrife, Galanthus nivalis, L.

Purple Marshwort, or -Marshlock, or Purplae-wort, from the colour of its flowers, and its being consequently regarded, as W. Coles tells us in his Art of Simpling, (ch. xxvii,) as "an excellent remedy against the purples," Comarum palustre, $\mathrm{L}$.

Purret, Fr. porrette, It. porreta, dim. of porro, the leek, L. porrum, Allium Porrum, L.

Purslane, in Turner Purcellaine, in the Grete Herball Porcelayne, Fr. porcellaine, It. porcellana, a name first used by Marco Polo in describing the fine earthenware made in China, and adopted from the name of a sea-shell, which resembles it in tcxture, and is so called from porcella, a dim. of L. porcus or porca, used in a figurative sense, as explained by Diez and Schcler. In Latin the plant was called portulaca, and this word seems to have bcen confounded with the more familiar porcellana. It certainly bears no resemblance to porcelain. Fuchs (Hist. plant. p. 111) derives its German name of Portzel kraut from L. porcellus, a pig. Portulaca olcracea, L.

Purslane, Sea-, Atriplex portulacoides, L.

Prrrie, the pear-trce, A.S. pirige,

Pyrus communis, L.

Quakers and Shakers, Quake-, or Quaking-grass, from its trembling spikclets, Briza media, L.

QLeEN of THE MLAD, L. Regina prati, from its flowers resembling ostrich feathers, the badge of royalty, Spiræa Ulmaria, L. 
QUICK-IN-TIIE-HAND, that is "Alive in the hand," tlie T'oueh-me-not, from the sudden bursting and contortion of its seed-pods upon being pressed,

\section{Impatiens Noli me tangere, L.}

Quicken or QUICK-BEAM, or WICKEN, a tree ever moving, A.S. cwic-beam, from cwic, alive, and beam, tree, translated in Elfrie's glossary "tremulus," a name applied by him to the aspen, but which has been transferred to this, the wild service, or roan tree, probably through some confusion between cwic and wicce, a witeh, and the roan being regarded as a preservative against witeheraft. Sec lios: Wicken is merely a different spelling of the same word. Whick is given in Levin's Manipulus as meaning "alive," "vivus."

Pyrus aueuparia, L.

QUICK-SET, from its being set to grow in a hedge, a quick or living plant, and forming what $\mathrm{Hyll}$ calls "a livelye hedge," as eontrasted with a paling or other fence of dead rood, the hawthorn,

Cratrgus Oxyaeantha, L.

QUILL-WORT, from its resemblanee to a bunch of quills,

Isoetes laeustris, L.

Quince, in Chaueer (R.R. 1. 1375) coine, of which quince seems to be the plural, Fr. coing, It. and Span. cotogna, L. cydonium, ealled in Greek $\mu \eta \lambda a \kappa v \delta \omega \nu \iota a$, from Cydon, a plaee in Crete,

Pyrus Cydonia, L.

Quitcil-grass, or TwITch, with an interehange of the initial eonsonant of frequent oceurrence, owing partly, perhaps, to the early copyists writing the letters $c$ and $t$ exactly alike, but also from a dialectic tendeney in somc distriets to pronounec $t w$ as $q u$, and $q u$ as $t w$, (see Atkinson's Clev. Dial. in v. 'Twill) the couch-grass, A.S. crcice, from cwic, vivaeious, Sw. kwikka. See СобсH.

Triticum repens, L.

RABone, Sp.rabano, L. raphanus, the radisb,

Raphanus sativus, L. 
HADISH, It. radice, root, L. radix, a plant valued for its root, Raphanus sativus, L.

„ IIorse-, a larger and stronger radish,

Cochlearia Armoraeia, L.

Ragaed Robin, Fr. Robinet dechiré, from its applieation, upon the doetrine of signatures, to the laeeration of the organ so-ealled, a name suggested by its finely laeiniated petals, Lyehnis Flos Cuculi, L.

R.Gimont, G. ragwurz, a term expressive of supposed aphrodisiae virtues, and originally assigned to plants of the Orehis tribe, as it is in Germany to the present day, and as we find it in all our own early herbals. With the same implied meaning tlie pommes d'amour are ealled by Lyte (b. iii. eh. 85) Rage-apples. In our modern floras the name Ragwort is, for no other assignable reason than its laeiniated leaves, transferred to a large groundsel,

Seneeio Jaeobæa, L.

Rainberim-thorn, (Florio in v.) the buekthorn, from $L$. rhamnus. See Rfine-Berries. Rhamnus cathartieus, $L$.

RaISIN-TREE, the red currant tree, from eonfusion of its fruit with the small raisins from Corinth ealled eurrants,

Ribes rubrum, $\mathrm{L}$.

RAMPE, in the sense of "wanton," from its supposed aphrodisine porvers, the cuekoo pint, Arum maeulatum, I.

RAMPION, Fr. raiponce, a word mistaken, as in the eases of "cerise" and "pease," for a plural, and the $m$ inserted for euphony; from L. rapunculus, a small rapa, or turnip; a bell-flower so called from its eseulent tubers,

Campanula Rapuneulus, L.

Raysies or Rasson, A.S. hramsa, Norw. rams, Da. ramse, Sw. rams, G. ramsel, from Dar. Sw. and Ic. ram, rank, a wild garlick so ealled from its strong odour, and the rink flavour that it eommunicates to milk and butter. Kimson would be the plural of ramse, as peason of pease, and oxen of $\mathrm{ox}$.

Allium ursinum, $\mathrm{l}$. 
RApe, L. rapus, or rapum, Brassica Rapa, Is.

Raspberry, in 'Turner's herlual ealled Raspis or Kaspices, of whieh the last syllables look like the Du. bes, berje, a berry. 'The first is more obseure. It ean scarcely be rasy, as the dietionaries explain it; for, although the sterns are rough, the fruit is not so. It seems, like several other names of plants, to be of double origin; being partly corrupted from Fr. ronce or rouce, a bramble, as brass from bronce, and partly from resp, as it is ealled in Tusser, a word that in the Eastem eounties means a sloot, a sucher, a young stem, and especially the fruit-bearing stem of raspberries. (Forby.) This name it may owe to the cireumstanee that the fruit grows on the young shoots of the previous year. Fr. in Cotgrave meure de ronce.

Rubus Idæus, L.

Rattle-box or Yellow Rattle, A.S. hrcelele or hratelmyrt, L. crotalum, Gr. кpotanov, from the rattling of the ripe seed in its pod,

, RED-,

Rhinanthus Crista galli, L.

Pedieularis sylvatica, $L$.

Rawbone, properly Rabone. See Runch.

RAY-GRass, Fr. ivraie, drunkenness, from the supposed intoxieating quality of the seeds of the darnel, a species of the same genus, Lolium perenne, $\mathrm{L}$.

REV-KNEEs, from its red angular joints, the eulrage or ilsinalt, Polygonum Hydropiper, L.

RED-LEGs, from its red stalks,

Polygonum Bistorta, L.

RED Monocco, from the eolour of the petals,

Adonis autumnalis, $\mathrm{L}$.

RED-ROT, from its supposed baneful effeet upon sheep, and its red colour,

Drosera, L.

RED-SILANKs, from its red stalks,

Polygonum Persiearia, L.

and in the Northern eounties, where it is a niekname for the 
Scotch Highlanders, the herb Robcrt,

Gcranium Robertianum, I.

REDWEED, the red poppy, not merely from its red flowers, but from these being used as a weed "or dye. "Ils teignent la laine en beau rouge, lorsqu'elle est traitée par l'alum et l'acide acetique." Duchesne, pl. utiles, p. 18:3.

Papaver Rhceas, $\mathrm{L}$.

REED, A.S. hreod, G. riet, and a similar name in all Germanic languages. It seems to be identical with Lat. arundo, in which the $i$ of the former is replaced with $u$, as in hirnndo compared with Gr. $\chi \in \lambda \iota \delta \omega \nu$, a swallow, and an $n$ inserted before $d$ for euphony. The initial $h$ of the A.S. hreod is also found in the Lat. harnndo of several MSS. and inscriptions. The root of the word unknown.

Arundo Phragmites, L.

REED-MACE, from the "Ecce homo" pictures, and familiar statues of Jesus in his crown of thorns, with this reed-like plant in his hand as a mace or sceptre,

Typha latifolia, L.

ReIndeER-moss, a lichen on which the reindeer feeds,

Cladonia rangiferina, Hoffm.

Rest-harrow, arrest-harrow, Fr. arrete-bcenf, from its strong matted roots impeding the progress of plough and harrow,

Ononis arvensis, $\mathrm{L}$.

RhINe-BERries, the fruit of the buckthorn, Du. rhynbesien, G. rainbeere, a name explained by Lyte (b. vi. c. 30) as meaning berries from the Rhine, by Adelung derived from rain, a boundary, the usual place of growth of the shrub, but perhaps from L. rhamnus,

Rhamnus catharticus, $\mathrm{L}$.

Rnvbarb, M.Lat. rha, from its oriental name raved, and barbarum, foreign, to distinguish this, a plant of the Volgat, from the Rha ponticum, another kind that came from the Roman province, Pontus, Rheum, $\mathrm{I}$.

"Monk's-,

* Rumex Paticntia, L. 
RIBBON-GRASS, the striped variety of

Digraplis arundinacea, PI3.

Ribwort, or RibGrass, from the strong parallel veins in its leaves,

Plantago lancerslata, $\mathrm{L}$.

RiE-GRass, a name that through some confusion betwerell rie and ray is by many farmers wrongly applied to the raycriass, a perennial darnel,

Lolium perenne, $\mathrm{I}$.

but by Ray, by Martyn in his Flora Rustiea, and all cureful writers assigned, with more propriety, to the meadow barley, the flowering spike of whieh somewliat resembles that of rye,

Hordeum pratense, $\mathrm{L}$.

Rish, the old spelling of rush.

Roax-tree, See Rowan.

ROAST-BEEF, from the smell of the bruised leaf, the stinking gladdon, Iris fœtidissima, $\mathrm{L}$.

ROBIN - RUN - IN - THE - HEDGE, LIZZY-RUN-UP-THE-HEDGE, names of the ground ivy, which seem to have been given to it from eonfusion of gill, ferment, Fr. guiller, with gill, a girl. See Gicl and Haymaids. Nepeta Gleehoma, B.

Rocambole, Fr. rocambolle, a word of uneertain derivation,

Allium Seorodoprasum, L.

Rock cREss, from its allianee to the eresses, and its growth upon roeks, Arabis strieta and petrea, Lam.

Rock-MOss, a liehen that grows on roeks,

Roceella tinetoria, $\mathrm{Ag}$.

Rock-Rose, a name that properly belongs to the Cisti, with whieh the English representatives of the order were onee comprised, from the resemblanee of some of them to a rose, and their growth on roeks, Helianthenum, L.

Rock-Tripe, Fr. tripe de roche, an edible liehen, upon whieh Sir J. Franklin and his companions supported themselves in Aretic Ameriea, and so ealled from some faneied resemblance,

Gyrophora vellea, Aeli.

Rocket, Fr. roquette, It. rucchetta, dim. of L. eruca, Eruea sativa, Lam. 


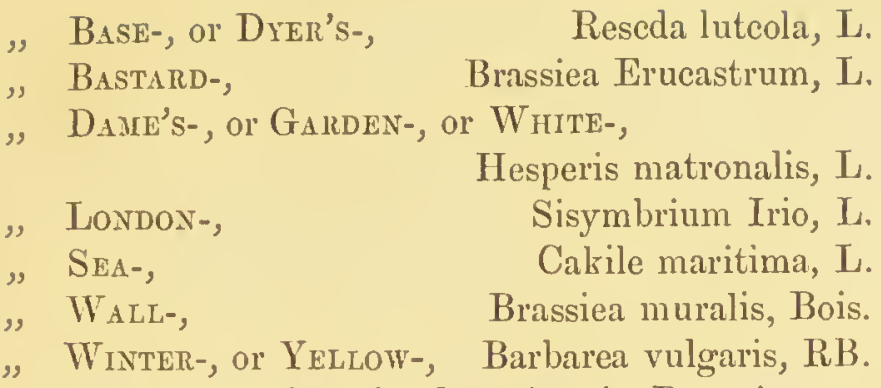

Rogation-FLOWER, from its flowering in Rogation week, the next but one before Whitsuntide, when processions were made to perambulate the parishes with the Holy Cross and Litanies, to mark the boundaries, and invoke the blessing of God on the erops. Gerarde says (p. 450) that " the maidens which use in the countrics to walke the procession, makc themselves garlands and nosegaies of it." It was for the same reason ealled Cross-, Gang-, and Proeession-flower. Polygala vulgaris, $L$.

Rose, L. rosa, a word adopted into most of the modern languages of Europe, Gr. pooov, whieh evidently means 'red,' and is nearly related to Go. rauds, G. roth, W. rhudd, Rus. rideyu, and Skr. rolidile, red. The L. rosa appears to be a foreign word introdueed to replaee a more ancient name for this shrub, rubus, whieh, like the Gr. pooov, is expressive of a red eolour, as we see from its derivatives, rubeus, ruber, rubidus, rubicundus, rubere, erubescere, rubigo, rubia, but which is employed by Latin writers merely in the sense of a bramble bush. Rosa would seem to be connected with pooov through a form in $t$, rota, whence rutitus, reddish, and L. rola, Wel. rhorl, Gael. roth, a wheel, so named, we may presume, from the rcsemblanee of its outline to a rose. The one eultivated in aneient times must have becn a erimson species, to judge from the myth of its springing from the

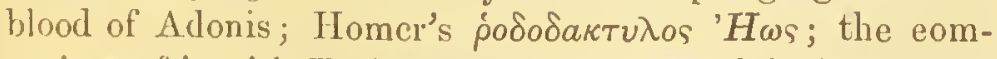
parison of it with Tyrian purple in Columella's line:

Jam rosa mitescit Sarrano clarior ostro ; 
and the distinet statement of Isidore (c. ix.) that it was called so, "quod rutilante colore rubet." Riosa, L.

$$
\text { " Brier-, or Dog-, or Hip-, R. canina, I. }
$$

"Burner-, from the resemblance of its leaf to that of the burnet,

R. spinosissima, Is.

, CabBaGE-, from its well filled flowers,

R. centifolia, L.

" Canker-, from its supposed injurious effect on wheat-crops, the red or field poppy, Papaver Rhoeas, L.

" China-, or Monthly-, R. indica, L.

"Christmas-, from its rose-like flowers, and its blossoming in the winter,

"Cons-, the field poppy, Papaver Rhoeas, L.

"DAMask-, from Damascus, R. damascena, Mill.

" DoG-, $\quad R$. canina, L.

"GUelder-, from its balls of white flowers which somewhat resemble a double rose, and its native country Gueldres, the sterile-flowered var. of the water elder,

Viburnum Opulus, L.

" Province-, from Provins, a small village about forty miles from Paris, where it used to be cultivated. Douce in Illustrations of Shakspeare, (vol. ii. p. 247,) says : "It was imported into that country from Syria by a count De Brie. There is an elegant cut and a good account of it in the first edition of Pomet, Hist. des drogues, 1694, fol. p. 174."

R. centifolia, L. var.

Rose-A-RUBy, L. rosa rubea, from its rich red flowers, Adonis autumnalis, $\mathrm{L}$.

Rose $\mathrm{B} \Delta \mathrm{Y}$, the name given by Turner to the oleander, but now, from resemblance of leaf in an outline drawing, improperly applied in some books to a very different plant: Epilobium angustifolium, L.

Rose Campion, the rose-coloured eampion,

Lychnis coronaria, L. 
Rose Elder, the elder that bears roses, the Guelder rose, Viburnum Opulus, L.

Rose-root, or -woRT, L. rhodia radix, from the odour of its rootstoek,

Rhodiola rosea, $\mathrm{L}$.

ROSEMARY, L. rosmarinus, sea-spray, from its usually growing on the sea-eoast, and its odour like that of the sea, Rosmarinus offieinalis, $\mathrm{I}$.

" Marsi-, or Wild-, from its narrow linear leaves like those of rosemary, Andromeda polifolia, L.

Rot-GRASs, from its being supposed to bane sheep, a grass in the sense of herbage, Pinguieula vulgaris, L.

Rowan, or Roan-TREe, ealled in the Northern eounties Ran or Royne, Da. and Sw. rönn or mun, the O.Norse runa, a eharm, from its being supposed to have power to avert the evil eye. "The most approved eharm against eantrips and spells was a braneh of the Rowan-tree planted and plaeed over the byre. This saered tree eannot be removed by unboly fingers." Jamieson's Seot. Diet.

"Roan-tree and red thread Haud the witches a' in dread."

Johnston in East. Bord.

The word runn, from Skr. $r u$, murmur, meant a seeret. A rin-wita was a private seeretary, one who knew his master's secrets; and from the same word were derived rynan, to whisper, runa, a whisperer, in earlier times a magieian, and rün-stafas, mysterious staves. From this last use of the word the name run eame naturally to be applied to the tree from whieh such staves were usually eut, as boc to that from whieh bonkstaves, locstafas, were made; but it does not appear to be aseertained why this tree should have been so exelusively used for earving runes upon, as to have derived its naine from them, not only in the British isles, but in the Scandinavian eountries also. There was probably a superstitious feeling of respeet for it derived from ancient times. Pyrus Aueuparia, Gärt. 
Rundes, a name that should mean a red or ruddy flower, and is hardly applicable to a yellow one, such as the narigold to which it is given in carly writers. But red and ruddy were formerly said of gold; as in the ballad of Robin Hood and the Sheplicrd:

"Here's twenty pounds in good red gold."

and in those of Germany, Flanders, Denmark and Sreden. The author of the Grete Herball, in speaking of this plant, says: "Maydens make garlands of it, when they go to feestes and bryde ales, because it hath fayre yellorre floures and ruddy."

Calendula officinalis $\mathrm{L}$. and the corn marigold, Chrysanthemum segetum, $\mathrm{L}$.

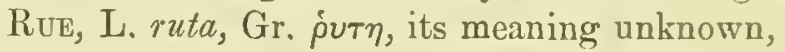

Ruta graveolens, L.

" MEaDow-, or FEN-, from its rue-like much divided leaves, and its place of growth, Thalictrum flavum, L.

WALL-, Asplenium Ruta muraria, L.

RuNCH, a coarse wild radish, the jointed charlock, a word of uncertain derivation, but one that in Scotland is applied to a strong rawboned woman, as a "runchie quean," in reference, as Jamieson thinks, to this plant.

Raphanus Raphanistrum, L.

RuptuRE-wonT, from its fancied remedial powers,

Herniaria glabra, L.

Rush, in old authors Ryschys, Rish, Resh, and Rishes, A.S. risc, related to It. lisca, reed,

, Boc-,

, Bul-, Mat-, or Pool-,

Juncus, L.

"CANDle-, from its furnishing wiclis,

Juncus effusus, L.

, Club-,

Scirpus palustris, $\mathrm{L}$.

" Dutch-, or Scouring-, Equisetum hyemale, L.

"Flowering-, from its tall rush-like stem and handsome head of flowers, "PIN-, Butomus umbellatus, $\mathrm{I}$. Juncus effusus, L. 
Rust, from an effect similar to the rust of iron produced upon plants by certain minute fungi, which have been supposed to be conditions of Puccinia graminis, but for the present are classified as Trichobasis Rubigo vera, Berk.

Rutabaga, the Swede turnip, so called from Sw. rotaluggar, root-rams. J. H. Lundgren in N. \& Q., 4th ser., v. $76 . \quad$ Brassiea campestris, L. var. rutabaga.

RYE, A.S. ryge, O.N. rugr, W. rhyg, O.H.G. roggo, Lith. ruggei, Rus. rosh, Pol. rez", Esth. rukki, a word extending, with dialectic modifications, all over Northern Asia, from which this grain scems to have travelled to the South and West. Its derivation unknown. See L. Diefenbach, (Or. Eur. No. 29,) and J. Grimm, (Gesch. d. D. Spr. p. 64).

Secale cercale, $L$.

Rye-grass, see Rie-grass, and Ray-grass.

\section{Sabiv, see Savine.}

SAFrlower, from its flowers being sold, as a dye, for genuine saffion, Carthamus tinctorius, L.

SAFrrov, Sp. azafran, Ar. al zahafaran, from Pers. zaafer (Littré),

Crocus sativus, $\mathrm{L}$.

SAGE, in Gower SAUlge, Fr. sauge, It. and Lat. salria, which by change of $l$ to $u$ became sannia, sauja, sauge, as ulveus, a trough, by the same process, ange, Salvia, L.

"WOOD-, from its sage-like leaves, and growth in woods, and about their borlers,

Teucrium Seorodonia, L.

SaINfors, sometimes spelt, as in Lyte, in Dale, and in Martyn's Flora Rustica, Saintfoin, in Hudson St. Foin, in Plukenet Sainet-foin, and thenee translated by some of our old writers "Holy hay," hut really formed from Fr. sain, wholesome, and foin, hay, L. sanum fonum, representing its older name Medica, which properly meant 'of Media,' but wats misunderstood as meaning 'curative.' Accurding to Plukenet and IIIll, the name was first given to the luecrne, 
Medieago sativa, and that of lueerne to an Onolurychis, cur jresent sainfoin. There does not appear to be any saint named Foin, nor any reason for aseribing divine propertios to this plant. Aeeording to Bomare, quoted by Juchesne, "Le S. est ainsi appelé pareeque c'est le fourage le plus appetisant, le plus nourrissant, et le plus sain, qu'on puisse donner aux ehevaux et aux bestiaux." (rood reasons for it name follow of eourse. The equivocal word Iledica is undoubtedly the origin of this one. See MEDick.

As at present applied, Onobrychis sativa, Lam.

Sarnfoin, in the Dietionary of Husbandry, 1717, lucerne, whieh is explained as "Mediek fodder, Spanish trefoil, and Snail or Horned elover grass," Medieago sativa, L.

ST. Anthory's Nut, the pignut, from his being the patron saint of pigs, "Immundissimas poreorum greges eustodire eogitur miser Antonius." Moresini Papatus, p. 133.

Bunium flexuosum, L.

St. ANThONY's RAPE or TURNEP, from its tubers being a favourite food of pigs, Ranuneulus bulbosus, $L$.

St. Barbara's cress, from its growing and being eaten in the winter, her day being the 4th Dee. old style; or, as the Grimms explain the G. synonym barbel- or barlenkraut, "weil es die barlen im baeh fressen," beeause the barbel in the brook eat it,

Barbarea vulgaris, DC.

St. BarnabY's Thistle, from its flowering at the summer solstiee, the 11th old style, now the 22nd of Jume, his day, whenee its Latin speeifie name,

Centaurea solstitialis, $\mathrm{L}$.

St. Bennet's herb, see Herb Bunnet.

St. Catharine's flower, from its persistent styles resembling the spoles of her wheel, Nigella damaseena, L.

S't. Christopher's herb, see Herb Christopher.

ST. DaboEc's HEATH, from an Irisl saint of that name, a speeies found in Ireland, Menziesia polifolia, Jus.

ST. JAMES's worT, either from its being used for the 
diseases of horses, of whieh this great warrior and pilgrim saint was the patron; or, aeeording to 'Tabernæmontanus, leeanse it blossoms about his day, the 25th July, whioh inay have led to its use in a veterinary practice upon male colts at this season ;

Seneeio Jaeobæa, L.

ST. John's wort, from its being gathered on the eve of St. John's day, the 2tth June, to be hung up at windows as a preservative against thunder and evil spirits, whence it was called Fuga dæmonum, and given internally against mania, Hyperieum perforatum, $\mathrm{I}$.

St. Patrich's Cabbage, from its oeeurrenee in the West of Ireland, where St. Patriek lived, the London pride,

\section{Saxifraga umbrosa, L.}

St. Peter's wort, of the old Herbals, the eowslip, from its resemblanee to St. Peter's badge, a buneh of keys, whence G. schliissel-blume,

Primula veris, $L$.

St. Peter's wort, of modern floras, from its flowering on his day, the 29th June, Hyperienm quadrangulum, L.

S.Alad, or Saliet, CorN-, from it being eaten as a salad, and growing in corn-fields, Valerianella olitoria, Poll.

Salad Burnet, a burnet eaten in Italy with salad,

"L'insalata non e bella, Ove non e la pimpinella."

See Pimperneli.

Poterium Sanguisorba, L.

SAlep, Mod. Gr. $\sigma a \lambda \epsilon \pi \iota$, Pers. sahaleb, the plant from which salep is made, Ar. aecording to Littré, tsaleb, a fox,

Orehis maseula, morio, and latifolia, L.

Saligot, lir. saligol, a sloven, or one who lives in dirt, from its growing in mud, a plant that Lyte tells us p. (536) was found in lis time "in eertayne places of this countrie, as in stues and pondes of cleare water," Trapa natans, L.

Sallow, A.S. scalh, salh, salig, O.H.G. salaha, Da. selje, O.N. selja, L. salix, Gr. é $\lambda \iota \xi$, Ir. sail and saileog, Sw. saly, Fin. salawa, different forms of a word that implies a slruls fit for withes, A.S. sal, or sal, a strup or tie, with a termi- 
nating adjectival ig or $h$, corresponding $t$, the $i x$, or es, or ica in the Latin names of shrubs. Sal, a hall, in O.H.F. a house, G. saal, seems to be of the same origin, and to tell us that our ancestors divelt in houses of wicker work, even men of rank. The L. aula, Gr. civ $\eta \eta$ is perhaps the sarne word as sal. It means both a stall and a hall. In fact, the royal sheepcote was in the primitive nation the royal palace, as among the Tartars of the interior of Asia is the arul at the present day. See Westmacott, p. 84. Salix, L.

SALtow-THORN, from its white willow-like leaves, and spinous branehes, Hippophae rhamuoides, L.

SAlsiry, Fr. salsifis, L. solsequinm, from sol, sun, and sequi, follow, a plant whose florver was supposed to follow the sun.

Tragopogon porrifolius, $\mathrm{L}$.

SAltwort, from its officinal Latin name Salicornia, salthorn,

Salicornia herbacea, L.

Glaux maritima, I.

Sampinte, more properly spelt Saypire or Sampier, Fr. Saint Pierre, It. Herba di San Pietro, contracted to Sampetra; from being, from its love of sea-cliffs, dedicated to the fisherman saint, whose name is the $\mathrm{Gr}$. $\pi \epsilon \tau p o s$, a rock, Fr. pierre,

Crithmum maritimum, L.

\section{Marsh-,}

Salicornia herbacea, L.

SAND-WEED, or -WORT, from its place of growth,

Alenaria, L.

Sanguinary, L. sanguinaria, the yarrow, from being eonfused, under the cquivocal name millefotium, with il horsetail that Isidore tells us (e. ix.) was formerly used to make the nosc bleed, and thence called herba sanguinarin. See Nosebletd.

Achillaea Nillefolinm, L.

SANICLE, a word usually derived immediately from L. sanare, heal, which on principles of etymology is impossible. Indeed it is, as Adelung remarks, au even question, whether its origin is Latin or German. The great abundance of the plant in the middle and north of Europe 
would ineline us rather to the latter as the likeliest, and it may be a corruption of Saint Nicolas, called in German Nickel. Whatever its derivation, the name was understood in the Middlc ages as meaning " eurative," and suggested many proverbial axioms, such as:

"Qui a la bugle et la sanicle, Fait aux chirurgions la nicle." "He who has bugle and sanicle makes a joke of the surgreons;" and

"Celuy qui sanicle a, De mire affaire il n'a."

"He who kecps sanicle, has no business with a doctor." Sanicula does not occur in classical Latin writers, and there is no such word as sanis or sanicus from which it could lave been formed. But in favour of the derivation from Sun Nicola or Sunct Nickel, is the wonderful Tale of a Tub, the legend of his having interceded with God in favour of two children, whom an innkeeper had murdered and pickled in a pork tub, and obtained their restoration to life and health. See Brady's Clavis Calendaria, vol. ii. p. 315, Forster's Perennial Calendar, p. 688, and Mrs. Jameson's Sacred and Legendary Art, p. 27:3. A plant named after this saint, and dedicated to him, might very reasonably be expected to "make whole and sound all wounds and hurts hoth inward and outward," as Lyte and other herbalists tell us of the sanicle. 'The Latin name, as in so many other cases, would be the nearest approael that could be made to the German. See Self-hedL. Sanicula europrea, L.

Great-, from resemblance of leaf,

Alchemilla vulgaris, L.

Saracens Coxsound, M.Lat. Consolida Saracennica. Parkinson says ('Tl. Bot. p. 540), that "it is called Solidago and Consolida from the old Latine word consolidare, which in the barbarous Latinc age did signify to soder, close, or irlue up the lips of wounds; and Saracenica, because the 'Turks and Saraeens had a great opinion thereof in healing the wounds and hurts of their people, and were aecomited 
great ehirurgions, and of wonderful skill thercin." Hence it was in German also called /leidnisch wundkraut.

Scnecio Saracenicus, W.

Satin-FLower, from the satiny dissepiments of its seedvessel,

Lunaria bicnnis, $\mathrm{L}$.

Satyrion, L. satyrium, Gr. oatuplon from oatupos, a satyr, a name applicd to several species of orchis, from their supposed aphrodisiac character. "Mulieres partium Italiæ dant eam radicem tritam eum lacte caprino ad incitandam libidinem." Herbarius, c. cxxviii. Orchis, L.

SaUce-ALONe, so called, according to W. Coles, from being "eaten in spring-time with meat, and so highly flavoured that it serves of itself for sauce instead of many others." This is an ingenious explanation of the name; but the real origin of it is more likely to be the It. aglione, Fr. ailloignon, coarse garlick. Like its German name, Sasskrant, sauce-herb, the English name will mean "saucegarlick," and refer to its strong alliaceous odour.

Erysimum Alliaria, L.

SAdGH, the sallow, A.S. sealh, Salix Caprea, L.

Savine, in Gower Saveine, from the Sabine district of Italy, Juniperus sabina, L.

Savoury, Fr. savorée, It. savoreggia, L. satureja,

Satureja hortensis, L.

SAtor, from the country of its discovery, Brassica oleracea, L. var. Sabauda.

SAW-WORT, from its leaves being nicked like a saw,

Serratula arrensis, $\mathrm{L}$.

SaxirRage, L. saxifraga, from saxum, rock, and frango, break, being supposed to disintegrate the rocks, in the crevices of which it grows, and thence, on the doctrine of signatures, to dissolve stone in the bladder. Isidore of Seville derives it primarily from this latter quality. The words in the Ort. San. are: "Der meister Ysidorus spricht, das dises kraut umb des willen heysst saxifraga, wann es 
den stein brichet in der blasen, und den zu sandt machet." It is for the same rcason called in Scotland Thirlstane.

Saxifraga, L.

Saxifrage, Burnet-,

GOLDEN-,

MEADOW-:
Pimpinella Saxifraga, L.

Chrysosplenium, L.

Silaus pratcnsis, Bess.

SCABWORT, from its use in veterinary medicine to cure scabby heels, the clecampane,

Inula Hclenium, L.

Scabious, L. scabiosa, scurfy, from scabies, scurf, in allusion to the scaly pappus of its seeds, which, on the doctrinc of signatures, led to its use in leprous diseases, and its being regarded as a specific remedy for such as were "raüdig " or "grindig," itchy or mangy. See Brunschwygkt. Scabiosa, L.

Scad-Tree, in Jacob's Pl. Faversh, the bullace,

Prunus communis, var. insititia, Huds.

SCALD-BERRY, from the supposed curative effect of its leaves boiled in lye in cases of scalled head, Park. Th. Bot., p. 1016, the blackberry, Rubus fruticosus, L.

SCALE-FERN, from the scales that clothe the back of the frouds,

Ceterach officinarum, W.

Scallon, a garlick from Ascalon in Syria,

Allium ascalonicum, L.

SCARLET-runNer, a climber with scarlet flowers,

Phaseolus multiflorus, L.

Scratica-Cress, from Iuat. Ischiatica, so called from its supposed effect in cases of irritation of the ischiatic nerve, a species of candytuft,

Iberis amara, L.

SCORPION-GIRAs, the old name of the plant now called "Forget-mc-not," and that under which it is described in all our Herbals, and all our Floras, inclusive of the Flora Londinensis and Gray's Natural Arrangement, to the cnd of the first quarter of this century, when the term "Forget-me-not" was introduced with a pretty popular" talc from Germany, and supcrseded it. It was called 
Scorpion-grass, from its spike resembling a scorpion's tail, and its being therefore supposed, on the doctrine of rignatures, to be good against the sting of a scorpion. Iyte tells us (b. i. c. 42) that in his day, 1578, it had "uone other knowen name than this."

Ny yosatis, L.

Scotcri Asphodel, a plant of the Asphodel tribe cornmon in Scotland, Tofieldia palustris, Huds.

Scotch FIr, from its being the one that grows wild in Scotland,

Pinus sylvestris, $\mathrm{L}$.

Scotcu Thistle, the national badge of Scotland, and in the first place a thistle of any kind, adopted, it is said, in consequenee of a night attack by a Danish army having been betrayed by the cry of one of the invaders who had trodden upon a thistle with his naked feet, at present assumed by artists, from no better reason than its clegant habit, to be the musk thistle, Carduus nutans, L. but by gardencrs taken to be a Mediterranean plant which docs not grow in Scotland, Onopordon Acanthium, L.

Scourlvg Rush, or Scrub-grass, a rush-like plant used in scouring utensils of wood or pervter, the Dutch rush, a species of horsetail, Equisetum hyemale, L.

Scrambling Rocket, a corruption of Crambling.

ScratchwEed, Fr. grateron, fiom gratter, scratch, the goose-grass or eleavers, so called from its rough-edged leaves,

Galium Aparine, L.

SCURVY-GRASS, -CRESS, or -WEED, frou its use against seurvy,

Cochlearia offieinalis, L.

SEA-BEET,

Beta maritima, L.

SEA-BELLS, -BINDWEED, Or - WLTHWIND,

Convolvulus Soldanella, L.

SEA-BELT,

SEA-BUCKTHORN,

SEA-BUGLOSS,

SEA-CALE, or -KALE, a eale or colewort that grows by the sea-side,
Laminaria saccharina, Lam. Hippophae rhamnoides, L. Pulmonaria maritima, $L$. Crambe maritima, $L$. 
SEA-GILLIFLOWER,

SEA-GRAPE,

SEA-GRASS,

SEA-HARD-GRASS,

SEA-HEATH,

SEA-HOLly, -HOLMe, or -HULVER,

Eryngium maritimum, L.

SEA-LACES, -Catgut, ol -Whipcord-, a marine alga,

Chorda Filum, Lam.

SEA-LAVENDER,

Sed-LyMe-grass,

SEA-MAT-WEED,

SEA-MILK-WORT,

SEA-POPPY,

SEA-PURSLANE,

SEA-RELD,

SEA-ROCKET,

SEA-STARWORT,

SEA-WEEDS,

Sedt-ront, from the round markings, like impr Statiee Limonium, L. Elymus arenarius, L. Psamma arenaria, P.B. Glaux maritima, L. Glaueium luteum, L. Atriplex portulacoides, L. Psamma arenaria, P.B. Cakile maritima, L. Aster Tripolium, L. Algæe.

SEAL-WORT, from the round markings, like impressions of a seal, on the root-stoek, the Solomon's seal,

Convallaria Polygonatum, L.

Seaves, rushes, a North-eountry word, Da. siv,

$$
\text { Juneus, L. }
$$

SEdGe, SEgG, or Segs, originally the same word, A.S. secg, whieh is identieal with sacg, and seax, a small sword, a dagger, and was applied indiseriminately to all sharppointed plants growing in fens; as rushes, reeds, flags, and sedges. 'Thus in a Wyeliffite version of Exod. ii. 3, "she trok a basket of rush," is, "sehe took a leep of segg." Their sense is at present limited; Sedge being now eonfined to the genus and Segg to the gladdou and flag-flowers, Carex, L, Iris, I.

SEE-BRIGIT, from its supposed effeet on the eyes (see Clary),

Salvia Selarea, L. 
Segarum, from its application as a vulnerary to newlycut rams, bulls, and colts, which in the North are callet seggrams and seggs. Sec StagGErwort.

Senecio Jacobrea, L.

Sej,F-Heal, correctly so spelt, and not'Slough-heal, for rcasons stated under this latter term. It meant that with which one may cure onc's sclf, without the aid of a surgeon, to which effect Ruellius quotes a Frenen proverb, that "No one wants a surgeon who keeps Prunelle." Scc Park. Th. Bot. p. 526. and also for the same rcason, Prunella vulgaris, $\mathrm{L}$. Sanicula europra, I.

Sengreen, A.S. sin, evcr, and grene, green, G. sinngrüi, from its evergreen leaves, the houseleek,

Sempervivum tectorum, $\mathrm{L}$.

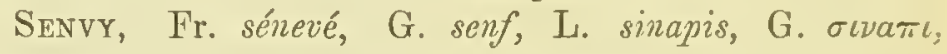
mustard, Brassica nigra, Boiss.

Septroir, or Setroil, from its seven leaflets, Fr. sept, and feuilles, Lat. in Apuleius, (c. 117,) septefolium, Gr.

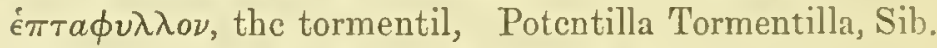

Service-, or, as in Ph. Holland's Pliny more correctly' spelt, Servise-Tree, from L. cervisia, its fruit having from ancicnt times been used for making a fermented liquor, a lind of beer :

\section{"Et pocula læti}

Fermento atque acidis imitantur vitea sorbis."

Virg. Geor. iii. 379.

Diefenbach remarks: (Or. Eur. 102) "biswcilen bedeutet cervisia einen nicht aus Getreide gebrauten Trank;" and Evelyn, in speaking of the fruit of the wild serrice tree, tclls us in his Sylva (cb. xv.), that "ale and beer brewed with these berries, being ripe, is an incomparable drink." The Cerevisia of the ancients was madc from malt, and took its name, we arc told by Isidore of Scville, from Ceres, Cereris; but this has eome to be used in a sccondary sense without regard to its etymological meaning, just as 
in Balm-tea we use tea in the sensc of an infusion, without regard to its being properly the name of a different plant. The French name of this tree, cormier, is derived from an ancient Gaulish word spelt by Dioseorides кoup $\mu$, which was a drink made from its berries, and that probably to which Virgil alludes. See Corne. Pyrus domestica, Sm.

Service, Wrld-, the rowan tree, Pyrus aucuparia, Gärt.

SeTwall, from M.Lat. Zedoar or Zeduar, the name of an Oriental plant for which this was sold, through the changes of $r$ to $l$, and $z$ to $s$, by which we get Zeduar, Zedualle, Setewale, as in Chaucer, and Setwal, a plant usually understood to be

Valeriana officinalis, L. but according to Lyte

Valeriana pyrenaica, L.

Setterwort, a plant so called becausc it was used for the operation of seltering. "Hushandmen are used to make a hole, and put a piece of the root into the dewlap of their cattle, as a seton, in eases of diseased lungs; and this is called pegging or settering." (Gerarde, p. 979.) Setter is a corruption of seton, It. setone, a large setu, or thread of silk.

Helleborus foetidus, L.

SHAKER, from the tremulous motion of its spikelets, the quaking grass,

Briza media, L.

Shallot, Fr. eschalotte, from L. Ascalonitis, of Asculon in Palestine, its native country, Allium ascalonicum, L.

SHanrock, Erse seamrog, compounded of seamar, trefoil, and $\circ g$, little, the seamar, in the opinion of L. Diefenbach, the same as sumar, in a word that is given by Marcellus of Bordeaux, physieian to Theodosius the Great, as the Celtic name of elover, visumarus. The plants that for : long time past have been regarded by the Irish as the true shamrock, and worn by them on St. Patrick's Day, are the black nonsueh, and the Dutch clover; and these, but chiefly and almost cxelusively the first, are sold for the national badge in Covent Garden, as well as in Dublin. Intermixed with them are several other speeies of the sime 
two gencra, medicago and trifolium, but no plant of any other genus. Of late years, however, several writers have adopted Mr. Bicheno's fancy, and advocated the claims of the wood-sorrel to this honour, but certainly without the smallest shadow of reason. Mr. J. Hardy, in an excellent article on the subject in the third number of the Border Magazine, has shown that the plant intended by the writers of Queen Elizabeth's reign was the watercress. Thus Stanihurst, in Holinshed's Chronicle, (ed. 1596,) says: " $\mathrm{W}^{\top}$ atercresses, which they tearme shamrocks, roots, and other herbs they feed upon;" a statement which he repeats in his work, "De rebus in Hibernia," p. 52. Fynes Morison also says that " they willingly eate the herbe shamrock, being of a sharp taste, which, as they run to and fro, they snatch like beasts out of the ditches." It will be objected to the watercress, that its leaf is not trifoliate, and could not have been used by St. Patrick to illustrate the doctrine of the Trinity. But this story is of modern date, and not to be found in any of the lives of that saint. The plant which is figured upon our coins, both Irish and English, is a conventional trefoil. As its leaflets are stipitate, it cannot have been meant for a wood-sorrel. That which I learn from Dr. Mnore, of Dublin, and other competent persons, has for many years been recognized in Ireland as the true Shamrock, is the black nonsuch,

\section{Medicago lupulina, $\mathrm{L}$.}

and occasionally mixed with it, or mistaken for it, the Dutch clover,

Trifolium repens, $\mathrm{L}$.

SHAREwORT, L. inguinalis, from being supposed to curc diseases of the share or groin, called buboes, whence one of its synonyms in old authors bubonium. The misunderstanding of this word bubonizm led to some ludicrous theories of the effect of the plant upon toads. The Ortus Sanitatis tells us (ch. 431) that it means toad-rcort, for that "bubo means toad. Inde bubonium. Aud it is so called, 
because it is a great remedy for the toads. When a spider stings a toad, and the toad is becoming vanquished, and the spider stings it thickly and frequently, and the toad cannot avenge itself, it bursts asunder. But if such a burst toad is near this plant, it chews it, and becomes sound again. But if it happens that the wounded toad cannot get to the plant, another toad fctches it, and gives it to the wounded one." A case is recorded in Topsell's Natural History, p. 729, as having becn actually witnessed by the Duke of Bedford and his attendants, at a place called Owbourn, (a mis-spelling of Woburn, and oftentimes related by himself. The error lias arisen from the confusion of bubo with bufo. The toad-flax has acquircd its name from a similar blunder. Aster Tripolium, L.

SHAVE-GRASS, from being "used by fletchers and combmakers to polish thcir work therewith," says W. Coles, Du. schaaf-stroo, from schaaf, a plane, and stroo, straw,

Equisetum hyemale, L.

SHEEP'S-BANE, from its cliaracter of baning sheep (see Ger. p. 528), the whitcrot, Hydrocotyle vulgaris, L.

Sheep's-bit, or Sheep's-bit-Scabious, so called to distinguish it from the Devil's-bit-scabious,

Sheep's Parsley, in Suffolk,

Jasione montana, L.

Chærophyllum temulum, L.

SheEp's Sorrel,

Rumex Acetosella, L.

Shelley Grass, or, as Threlkeld spells it, Skally Grass, a word the origin of which is obscurc, perliaps the Sc. skellie, which means " charlock," extcnded to weeds in gencral, the couch-grass,

SHEPHERD's CRESS,

SHEPIERD's NEEDLE,

Shepinerd's purse, 'Triticum repens, L. Teesdalia nudicaulis, RB. Scandix Pccten, L.

SHEPHERD'S ROD, or STAFF, L. virga pastoris, the small tcascl,

Dipsacus pilosus, L 
Shepherd's, or Poor Max's Weatuler-glass, from its closing its flowers beforc rain, tle red pimpernel,

Anagallis arvensis, $\mathrm{L}$.

Sineme-grass (Turn.i. 112), sedgr, from its cutting edges, A.S. sceran, shcar,

Carcx, $\mathrm{L}$.

Shore-grass, or Shore-tweed, from its usual place of growth,

Littorella lacustris, L.

Sickle-wort, L. secula, from its flowers, when scen in profile, resembling a sicklc,

Prunclla vulgaris, $L$.

Siethes, in Tusser, a kind of chives, spclt in Holybande Sieves, from the Fr. cive, Allium fissile, I.

SILver Frr, from the silvery whiteness of the under surface of its leaves,

Pinus picea, L.

Silver-weed, L. Argentina, from the silvery under surface of its leaves,

Potentilla anserina, $\mathrm{L}$.

SimpLins' Joy, from the good sale they had for so highly esteemed a plant, the vervain, Verbena officinalis, $L$.

Srason, Fr. seneçon, in Bulleyn Sextion, and in the Eastern counties Stircion, corruptions of L. senecio, -onis, a name derived from senex, an old man, and given to the common groundscl in allusion to its heads of white hair, the pappus upon tho seed:

"Quod canis similis videatur flore capillis."-NIacer;

or, as Bulleyn expresscs it: "because the flower of this lerbe hath white hair, and when the winde bloweth it away, then it appeareth like a bald-headed man."

Senecio vulgaris, L.

SkEG, in Ph. Holland's Pliny (b. xviii. c. 6) and Florio, the sloe-tree, from its rending clothes, as a sceg, or ragged projecting stump might,

Prunus spinosa, L.

, in Kent the bullace.

SkEwER-WOOD, from skewers being made of it, the spindle-tree,

Evonymus europæus, L.

Skirret, in old works called SKYrwort or SKrrmyt, Du. suikerwortel, sugar-root, Sinm Sisarum, L. 
Skolicar, from the shape of the calyx,

Scutellaria galericulata, L.

Sleep-at-noon, from its flowers closing at midday, the goat's beard,

Tragopogon pratense, L.

SLEEPWORT, from its narcotic properties,

Lactuca virosa, L.

Sloe, in Lancashire slaigh or sleawgh, A.S. sla-, slag-, or slah-porm, the sla meaning not the fruit, but the hard trunk, a word that we find in our own, and in all its kindred langunges, to be intimately connected with a verb meaning slay or strike.

NOUN.

A-S. sla

slage

Eng. sloe, O.E. sle slay

Du. and L.G. slee slaan

G. schlehe
VERB.

slean

slagan

schlagen
Noun.

Da. slaaen

Sw. slà

Icel.

Old Fries.

Old Sax.
VERB.

slaa

slà

sla

sla

Whether this connexion is due to the wood having been used as a flail (as, from its bcing so used at this day, is most probable) or as a bludgeon, can only be discovered by a comparison of its synonyms and the corresponding verb in other languages of the Ind-Europcan group.

\section{Prunus spinosa, L.}

Sloke, Slauke, or Slake, a Gaelic name given to several species of edible Porphyræ and Ulvæ.

Slodgh-HEAL, a supposed, but mistaken correction of Self-heal, the slough being that which is thrown off from a foul sore, and not that which is healed, the wound itself. Besides, the term slough was not used in surgical language till long after the plant had been called Selfe-heal, and applied as a remedy, not to sloughing sores, but to fresh cut wounds. Scc Sflf-heal. Prunella vulgaris, L.

Sirallage, a former name of the celery, meaning the small acke or parsley, as compared with the $i \pi \pi 0 \sigma \epsilon \lambda \iota v o v$, 
or great parslcy, olus atrum. Scc Turner's Nomenclator, A.D. 1548, and Gerarde. Sce also Acriv.

Apium graveolens, $\mathrm{L}$.

SMOKE-WOOD, from boys smoking its porous stalks,

Clematis Vitalba, L.

Surv, from its rescmblanec to the smut on kettles, a fungus that attacks the ears of corn and other grasses,

Uredo secretum, P.

SNaG, in Cotgrave, and in Lyte (b. vi. ch. 47), the sloe, from its branches being full of small snags or projections,

Prunus spinosa, L.

SNaIl Clover, from the spiral convolutions of its legumes, the lucerne genus,

Medicago, L.

SNAKE'S HEAD, from the checkered markings on the pctals like the scales on a snake's head,

Fritillaria Meleagris, L.

SNAKE'S TAIL, from its cylindrical spikes, the sea hardgrass,

Ophiurus incurvatus, RB.

SNAKE-WEED, the bistort, from its vrithed roots,

Polygonum Bistorta, L.

SNAP-DRAGon, from its corolla resembling the snap or snout, Du. sneb, G. schnabel, of some animal. It means, perhaps, "Snap, dragon!" Antirrhinum majus, L.

SNEEZE-wonT, from the powder made from it causing

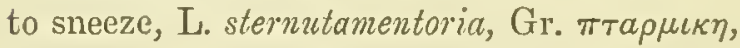

Achillea Ptarmica, L.

SNow-Ball Tree, from its round balls of white flowers, a var. of the Guelder rose, Viburnum Opulus, $\mathrm{L}$.

SNOWBERry, from the white colour and snowlike pulp of its fruit,

Symphoria raccmosa, $\mathrm{Ph}$.

SNow-Drop, from G. schneetropfen, a word that in its usually accepted sensc of a drop of snow is inconsistent; for a dry powdery substanec, like snow, camot form a drop. In fact, the drop refers, not to icicles, but to the large pendants, or drops, that were worm by the ladies in 
the sixtecnth and seventeenth centuries, both as car-rings and hangings to their brooches, and which we sce so often represented by the Dutch and Italian painters of that period.

Galanthus nivalis, L.

SNoW-FLAKE, a name invented by W. Curtis to distinguish it from the snow-drop, Leueojum restivum, L.

Sosprort, from its being used in scouring (Ger. p. 360), and frothing in the hands like soap, says Brunschwygk,

Saponaria offieinalis, L.

Soldier-orchis, from a fancied rescmblance in it to a soldier,

Orchis militaris, L.

Solonon's SEAL, from the flat round scars on the rootstock, resembling what is ealled a Solomon's seal, a name given by the Arabs to a six-pointed star, formed by two equilateral triangles intersecting each other, and of frequent oceurrence in Oriental tales; as in the first story of the Arabian Nights; Convallaria Polygonatum, L.

Sops-IN-WINe, from the flowers being used to flavour wine. Chaveer says of it, writing in $\mathrm{Edw}$. III's reign :

"There springen herbes grete and smale,

The licoris and the setewale,

And many a clove gilofre,

And notemuge to put in ale,

Whether it be moist or stale." T. of Sir Th. 49 .

The plant intended was the elove-pink, -gilofie, or -gilliflower,

Dianthus Caryophyllus, I.

Sorb, L. sorbus, from sorbeo, drink down, in allusion to a bererage made from the fruit. See Service-Tree. A name formerly given to at present to Pyrus domestica, L. Pyrus torminalis, L.

Sorren, Fr. surelle, a dim. derived from L. Germ. suur, sour, from the acidity of the leaves, Rumcx Acetosa, L.
"Sheep's-,
WOOD-,
Pumex Acctosella, L.
Oxalis Acetosella, $\mathrm{L}$.

Sourings and SweEtings, crabs and sweet apples. 
Sourhirnwood, A.S. suðernewule, abridged from superue wermod, southern wormwood, as in Lib. Med. (O. Cockaysue, Leechd. i. p. 5 l).

Artemisia Abrotanum, I.

Sowbane, from being, as Parkinson tells us ('Th. But. p. 74.9), "found eertain to kill swinc,"

Chenopodium rubrum, L.

Sowbread, G. saubrodt, L. panis porcinus, from its tuber being the food of wild swine,

Cyelamen europreum, I.

Sow Thistur, in Pr. Pm. thowthystil, A.S. prefepistel, or pupistel, O.G. du-tistel, sprout thistle, from bufe, a sprout, an indieation of the plant having been valued for its edible sprouts, whieh Evelyn tells us were eaten by Galen as a lettuee, and, as we learn from Matthioli (1. ii. e. 124), thcy were by the Tuscans, even in his day: "Soneho nostri utuntur hyeme in acetariis." It seems to have been called sow-thistle, through its name in the Ortus Sanitatis (e. cxlviii.) suwe-distel, or, in some editions, saw-distel, a corruption of its A.S. and older German name.

Sonchus oleraceus, L.

SowD-wort, the soda-plant, the plant from the ashes of which soda is obtained, Fr. soude, L. solida, soda being the solid residue left by boiling a lye of its ashes,

Salsola Kali, L.

Sowrr, Wood-, see Sorrel.

Sparagus, in Evelyn's Acetaria, shortened from Lat. Asparagus, as Emony from Anemony, by the mistake of the initial vowel for the indefinite artiele, $a$ or $a n$, and further eorrupted to Sparrow-grass, an example of the habit of the unedueated to explain an unknown word by a more familiar one; Asparagus offieinalis, $\mathrm{L}$.

Sparrow-Tongue, from its small aeute leaves, the knotģlass,

Polygonum avieulare, $\mathrm{L}$.

SpART-Grass, in the Northern counties (Brockett), "a 
dwarf rush common on moors and wastes ;" a name given to scveral different species of rush;

Juncus, L.

Spatting-Poppr, from A.S. spatlian, to froth, from the spittle-like froth often seen upon it caused by the bite of an insect,

Silene inflata, L.

SPEAR-grass, in Shakspeare (Henry IV. lst part, A. ii. sc. 4), and in Lupton's Notable Things, a plant used to tickle the nose and make it bleed; the common reed, sce SPIRes,

Phragmites communis, Trin.

Spear-Mint or Spire-aint, from its spiry, not capitate inflorescence,

Mentha viridis, $L$.

SPEEDWELL, from its corolla falling off and flying away as soon as it is gathered; "Speed-well!" being equivalent to "Farewell!" "Good-bye!" and a common form of valediction in old times. "Forget-me-not," a name that has since passed to a myosotis, appears to have first been given to this plant, and addressed to its fleeting flowers. See Forget-ue-not. Veronica Chamædrys, L.

Spezt, the same word in Du. Ger. Da. and Sw. the It. spelda, Sp. espelta, Fr. espeautre, from G. spalten, split. spelt is explained in Levin's Manipulus by eghumare, to husk.

Tritieum Spelta, L.

Sperage, Fr. esperage, from L. asparagus, Asparagus offieinalis, L.

Spikenet, Spicknel, or Spignel, Sp.espiga, spike, and eneldo, from L. anethum, dill, a plant that was imported from Spain under that name; see Lyte, b. iii. c. 15;

Meum athamanticum, $\mathrm{L}$.

Sprisicn, It. spinace, derived, according to Diez and Scheler, through a presumed M.Lat. spinaceus, spiny, from L. spina, a thorn, in allusion to its sharp-pointed leaves, or, as Littré and others with more reason say, to its prickly fruit. If we assume a word for whieh we have no authority, spinax would bring us nearer to the It. spinace than spinaceus. 'The analogy of other plant-names would 
suggest a M.Lat. spinago. But the word seems to have an entircly different origin. Fuchs tells us (Hist. Stiry. p. 665), that it is called in Arabic Mispanach : "Arabica" fuctionis principes /lispanach, hoc est, Hispanicurn ohus nominant." Dodoens (b. v. i. 5) tells us also, "Spinachiain nostra æas appellat, nonnulli spinachenm olus. Ab Arabibus et Serapione IIispanac dieitur." Brunfelsius (ed. 1531) says expressly at p. 16, "Quæ vulgo spinaclia hodie, Atriplex Hispaniensis dicta est quondam; eo quod ab, Hispania primum allata est ad alias cxteras nationes." Tragus also calls it Olus Hispanicum; Cotgrave, /lerbe

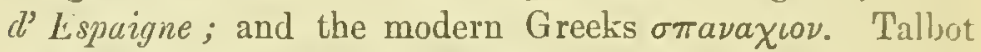
in Engl. Etym. talics the same view, and considers the name as meaning "Spanish." It is probably one of those many words which, being of foreign origin and misunderstood, have been altered into others of more familiar sound.

Spinacia oleracea, L.

Spindle-tree, from its furnishing wood for spindles, A.S. spindel, which meant, not so much the implement used in spinning, as a pin or skewer, a purpose for which it is used to this day, and whence it has taken its other names of Gadrise, Prickwood, Skerver-wood, etc.

Evonymus europæus, L.

SpINks, or Bog-spinks, Du. pinkster-bloem, from their

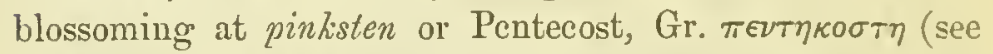
PINK), the Lady's smoek, Cardamine pratensis, L.

SpIREs, ol SpIRE-REed, the pool-reed, A.S. pol-spere, in the Wycliffite version of the bible called Spier, as Exod. ii. 3: "Iche puttide hym in a place of spier," and Job ix. 11: "Whether a spier may wexc without water." In the Owl and Nightingale, 1. 19, SPrre;

"I-meind mid spire and grene segge."

Probably it meant a spear, A.S. spior or spere, and in the first place was so named from the Spanish reed, Aruudo 
Donax, having been imported and used for missiles. In later times we find this word in the sense of a pointed inflorescence, as a "spyre of corne," Palsg. "I spyre as corne doth." ib. Spire is in different counties applicd to several different plants, such as rushes and sedges. It usually means the common reed,

Arundo Phragmites, L.

SPLEEN-WORT, from its supposed efficacy in diseases of the spleen, Gr. $\sigma \pi \lambda \eta \nu$, a notion suggested, on the doctrine of signatures, by the lobular form of the leaf in the species to which the name was first given, the ceterach. See Miltwaste.

Asplenium, L.

Spoonwort, G. löffel-kraut, from its leaf being shaped like an old-fashioned spoon; whence also its Latin name;

Cochlearia officinalis, L.

Spret, a name given in the northern counties to several rushes which grow in damp meadows that are thence called spretty, more particularly, Juncus articulatus, L.

Spreusidany, from L. peucedlanum,

Peucedanum officinale, L.

Spring-grass, sec Vernal-grass.

Spruce, from G. sprossen, a sprout, as the tree from the sprouts of which sprossen-bier, our spruce-beer, is made. Evelyn, from the expression he uses: "Those of Prussia, which we call Spruse," seems to have fancied that it meant "Prussian."

Pinus Abies, L.

SPURGe, Fr. espurge, L. expurgare, from its medicinal cffects, Euphorbia, L.

" CAPER-, from its immature fruit being substituted for the real caper, Euphorbia Lathyris, L.

"SuN-, from its flowers turning to the sun, Euphorbia helioscopia, L.

Spurge Latrel,

Spurge Olive, Dapline Laureola, L. Spur-wort, It. speronella, from its verticils of leaves 
resembling the large spur-rowels formerly worn,

Sherardia arvensis, Is.

Spurry, a word from which Lyte says (b. i. ch. 38) that the Lat. spergula was formed. It seems more likely that spergula is contraeted from asparagula, a presumed dirn. of asparagus, a plant whieh it somewhat resembles, and spurry from spergula. The G. spark, and Fr. espargoutte, seem to be the same word differently developed. Cotgrave gives is Fr. spurrie.

Spergula arvensis, L.

SPURT-Grass, a rush of which the baskets were made: that were ealled in A.S. spyrtan, and which seem, from one of Zlfrie's eolloquies, to have been used for eatehing fish. This word spyrta has probably been formed from L. sporta, a basket made of spartum, the Sp. esparto, the grass so mueh used for mats and baskets in the South, and related to $\mathrm{Gr}$. $\sigma \pi \epsilon \iota \rho a \omega$, twist, wreathe.

Seirpus lacustris and maritimus, $L$.

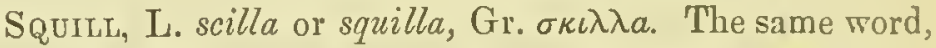
the It. squilla, is now used to mean the small evening bell sounded from the eampanili in Italy for vespers serrice, and this Diez would derive from O.H.G. shilla, G. schelle, and the verb skellan, ring, and quotes a passage from the Lex. Sel. "Si quis schillain de eaballo furaverit," to show its original use as a horse-bell. It seems far more probable that the little bell should have been so ealled from its resemblanee to the bulb of an Italian plant, and its name liave been adopted by other nations with the Christian religious rites, than that Italians should have first learnt a name for sueh an old invention from the Germans. But be the origin of squilla what it may, the flower was not ealled so from any resemblanee to a bell, as its synonym "Harebell" might lead us to suppose, but is simply the Gr. word $\sigma \kappa l \lambda \lambda a$.

Seilla nutans, ete. Sm.

Squinancy, from its supposed effieaey in euring the disease so ealled in old authors, viz. the quinsy, Fr. esqui- 


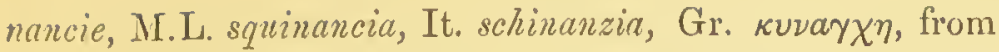
$\kappa \nu \omega \nu$, dog, and $\iota \gamma \chi \omega$, strangle, a dogr-ehoking disease, onc in which the patient, from inflammation and swelling of the fauees, is obliged to gasp with his mouth open like a strangled $\log$,

Aspcrula eynanehica, L.

Squinancy Berries, black eurrants, from their use in sore throat, Ribes nigrum, L. Squirrer TaIr, from the shape of the flower-spike, Hordcum maritimum, With.

Squitch, or Quirch, A.S. cwice, from cwic, vivaeious, the eouch-grass, so called from its tenacity of life,

Triticum repens, and Agrostis stolonifera, L.

STAB-wort, the wood-sorrel, so called, according to Parkinson (Th. Bot. p. 747), "because it is singular good in all wounds and stabbes into the body." By most authors it is spelt stubwort.

Oxalis acetosella, $\mathrm{L}$.

Staggerwort, usually understood to be so called from curing the staggers in horses, but to judge from its synonym Seggrum, and its being found in some works spclt Staggwort, more probably derived from its application to newly-castrated bulls called Seggs and Staggs,

Senecio Jaeobæa, L.

Standerwort, or Standergrass, Fl. standelkruid, G. stendel-vourtz, Sw. standört, names of which it is needless to unveil the meaning, but descriptive of a supposed effect of the "Foul standergrass," suggested by its double tubers, which, on the doetrine of signatures, indicate aphrodisiac virtucs,

Orchis mascula, L.

Stanmarcil, O.E. stane, stonc, and march, parsley, a translation of Gr. $\pi \epsilon \tau \rho \circ \sigma \epsilon \lambda \iota \nu o \nu$, the Alexander, which usually grows among the stones of ruined buildings, and on rubbly or rocky ground, Smyrnium Olusatrum, L.

STar-Fruit, from the radiated star-like growth of its seed-pods, Actinocarpus Damasonium, L. 
Star-grass, a grassy-looking aquatic plant with stellate leaves,

Callitriche, I.

Star Hyacintu, from its open stellate flowers,

Seilla verna, Hud.

STAR-JELLY, the nostoe, a jelly-like alga popularly supposed to be shed from the stars, Nostoe commune, Ag.

Star Thistle, from its spiny involucre, resembling the weapon ealled a morning star, Centaurea solstitialis, L.

Star-wolit, from the shape of the flower.
"SEA-,
Aster Tripolium, L.

Star of Bethlehen, from its white stellate flowers, like pietures of the star that indicated the birth of Jesus,

\section{Ornithogalum umbellatum, L.}

Star of the Eartir, from its leaves spreading on the ground in star fashion, Plantago Coronopus, L.

Star of Jerusalem, It. girasole, turn-sun, its Italian name familiarized into Jerusalem, the salsify,

Tragopogon porrifolius, L.

STARCH-CORN, from stareh being made of it,

Tritieum Spelta, I.

STARCH-WORT, from its tubers yielding the finest starch for the large eollars worn in Queen Elizabeth's reign,

Arum maeulatum, L.

StaRe, or Starr, Dan. star, or stär-gräs, Te. stör, Sw. starr, words meaning "stiff grass," as in Douglas's Virgil (b. vi. 1. 870):

$$
\text { "rispis harsk and stave," }
$$

a name applied to various sedges and eoarse sea-side grasses, more espeeially

Cirex arenaria, L. and Ammophila arundinaeea. Host.

STAVER-WORT, from being supposed to eure the starers or staggers in horses,

Seneeio Jaeobra, Is.

Stavesacre, a plant that was onee in great use for destroying liee, but whieh with the gradual inerease of cle:lnly habits is beeome searee in our gardens, L. stay, his- 


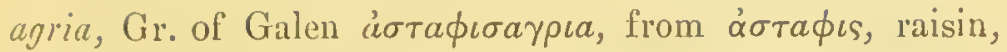
and $\alpha \gamma p$ sa, wild, referring to the similarity of its leaf to that of the vine; unless Galen's plant was an entirely different one, for which ours has becn mistaken;

\section{Delphinium Staphisagria, L.}

Stay-Plough, the rest-harrow,

Ononis arvensis, $\mathbf{L}$.

STickadove, a name corrupted from the officinal Lat. flos sloechados, flower of the stoechas, a lavender so called from growing on the Hyercs, islands opposite Marseilles, and called by the ancients Stoechades, from standing in a

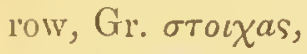
Lavandula Stoechas, L.

Stinkrorn, from its shape and offensive odour, Phallus impudicus, L.

STITCH-worT, in a thirteenth eentury MS. in Mayer and Wright, p. 14:0, spelt Stich-wurt, and given as the translation of "Valeriane," a plant used to cure the sting, G. stich, of venemous reptiles; but in later works explained as curing the stitch in the side. See Gerarde, p. 140.

Stellaria Holostea, I.

Stock-Gilliflower, now shortened to Stock, from stock, the trunk or woody stem of a trec or shrub, added to Gilliflower to distinguish it from plants of the Pink tribe, called, from their seent, Clove-Gilliflowers,

Matthiola incana, $\mathrm{L}$.

STоск-Nут, from its growing on a stick, G. slock, and not on a tree like the walnut,

Corylus Avellana, L.

STone Bisit, a basil that grows among stoues, Calamintha Clinopodium, Benth.

STONE-BREAK, G. steinbrech, from L. sarifraga, so named from its supposed power of rending rocks, and thence cmployed to brcak stone in the bladder, Saxifraga, L.

STONE-crop, from crop, a top, a bunch of flowcrs, a cima, and stone; being a plant that grows on stone walls in dense tuf'ts of yellow flowers;

Sedum acre, $\mathrm{L}$. 
STONE-Fers, from its growtl on stone walls and rocks, Ceterach officinarum, WW.

Stone-hot, or Stonxond, corruptions of stone-vort, and Stone-hore, or Stowor, of stone-orpine, (see Orrine,

Sedum reflexum, I.

STONE-Tront, from caleareous deposits on its stalk,

Chara, L.

STones, a translation of Gr. op $\chi \iota s$, a name given to several orehideous plants from their double tubers, and in old herbals used with the name of some animal prefixed, as, e.g. that of the dog, fox, goat, or hare, Orehis, L.

Strangle-Tare, a tare that strangles, a name given to several speeies of Lathyrus and Vicia, L. also a plant that strangles a tare, Cuscuta europæa, L.

Strap-WORT, L. corrigiola, a little strap, dim. of $\mathrm{L}$. corrigia, so ealled from its trailing habit,

Corrigiola littoralis, $\mathrm{L}$.

Strawberry, A.S. streowberie, either from its straw-like halms, or from their lying strown on the ground. Some have supposed that the name is derived from the custom in some parts of England to sell the wild fruit threaded on grass-straws. But it dates from a time earlier than any at. which wild strawberries are likely to have been marketable.

Fragaria vesea, $L$.

Strawberry Clover, from its round pink strawberrylike heads of seed, formed by the inflated ealyx,

Trifolium fragiferum, L.

STRAwBerRy-tree, from the shape and colour of its fruit, Arbutus Unedo, L.

STuвworT, from its growing about the stubs of hem trees, the wood-sorrel, Oxalis Acetosella, L.

Strntion, a corruption of L. nasturtium, a cress, a popular name of a plant which from the flavour of its leaves was by the old herbalists ranked with the cresses, T'ropæolum majus, L. 


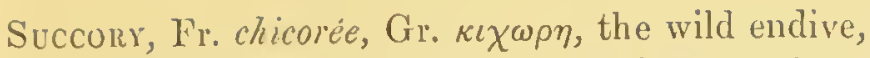
Cichorium Intybus, L.

SulpHCR-wort, from its roots being, according to Gerarde (p. 1053), "full of a yellow sap, which quirkly waxeth hard and dry, smelling not much unlike brimstone, ealled Sulphur,"

Peucedanum officinale, L.

Sundew, a name explained by Lyte in the following description of the plant. "It is a herbe of a very strange nature and marvellous: for although that the Sonne do shine hoate and a long time thereon, yet you shall finde it alwayes moyst and bedewed, and the small heares [hairs] thereof alwayes full of little droppes of water: and the loater the Sonne shineth upon this herbe, so much the moystier it is, and the more bedewed, and for that cause it was called Ros Solis in Latine, whiche is to say in Englishe, The dewe of the Sonne, or Sonnedewe." Nevertheless, the Gcrm. name, sindau, leads us to suspect that the proper meaning of the word was "ever-dewy," from A.S. O.S. and liris. sin, ever, rather than from sun. The Latin name, Ros solis, is modern, and, as the plant is seldom met with in the South of Europe, is probably a mistranslation of the German or English one. Drosera, L.

Sunflower, from its "resembling the radiant beams of the sun," as Gerarde says; or, as another old herbalist expresses it in Latin, "idea sua exprimens solis corpus, quale a pictoribus pingitur;" and not, as some of our popular pocts have supposed, from its flowcrs turning to face the the sun, which they never do; a delusion that Thomson expresses in the lines:

"But one, the lofty follower of the sun,

Sad when he sets, shuts up her yellow leares,

Drooping all night, and, when he warin returns, Points her enamour'd bosom to his ray."

$$
\text { Summer, 1. } 216 .
$$

Helianthus annuus, L. 
also in some herbals, from its only opening in the sunshine, the roek rose, Helianthemurn vulgare, Gärt. but in our older poets, the marigold, as in IIcywrood's Marriage Triumphe:

"The yellow marigold, the sunne's own flower."

"It was so named," says IIyll, "for that after the rising of the sun unto noon, this flower openeth larger and larger: but after the noontime unto the setting of the sun the flower eloseth more and more, so that after the setting thereof it is wholly shut up." Hyll, Art of Gard. e. xxx.

This, the Marigold, is the plant which Ovid means, (Jetam. Lib. iv. 1. 269) :

"Illa suum, quamvis radice tenetur,

Vertitur ad Solem ; mutataque servat amorem."

It is also the flower that in Anglo-Saxon is ealled solscee, Fr. souci, from O.F. soucicle, L. solsequium, sun-following. Calendula offieinalis, L.

Sun-sPurge, from its flowers turning to face the sun, the wart-wort,

Euphorbia helioseopia, L.

SWALLOW-PEAR, a wild pear that is not a "ehoke-pear," a kind that may be eaten, Pyrus torminalis, $\mathrm{L}$.

Swallow-wort, Gr. $\chi \epsilon \lambda \iota \delta o \nu \iota \nu \nu$, of $\chi \epsilon \lambda \iota \delta \omega \nu$, a swallow, beeause, aeeording to Pliny (b.xxv. eh. S), it blossoms at the season of the swallow's arrival, and withers at her departure, a name, that, for the same reason, has been given to several other plants, as the Ranuneulus Fiearia, Fumaria bulbosa, Caltha palustris, and Saxifraga granulata, L.; but, aeeording to Aristotle and Dioseorides, beeause swallows restore the eyesight of their young ones with it, even if their eyes be put out. It is to be reeolleeted, that, however absurd some of these superstitions, they may nevertheless be the real souree of the name of a plant. Chelicionium majus, $L$.

Swede, a turnip so ealled from having been introdueed from Siweden, Brassiea eampestris, L. var. rutabaga. 
Sireet Alrson, a plant with the smell of honey, a species of Alyssum, of which Alison is a corruption, and not the name of a lady, Alyssum maritimum, L.

SwEET BAY, from the odour of its leaves, to distinguish it from other cvergrcen shrubs, such as the strawberry tree and cherry laurel, that were once reckoned among the bays, Laurus nobilis, L.

Sweet-Briar, a wild rose whose leaves are sweet-scented, Rosa rubiginosa, $\mathrm{L}$.

Sweet Chervil, or Sweet Cicely, from its agrecable scent, Gr. $\sigma \epsilon \sigma \in \lambda \iota$, Myrrhis odorata, Scop.

Sweet Flag, to distinguish it from the unscented flag, or iris,

Acorus Calamus, Is.

Swekt GaLe, from its scent, Myrica Gale, L.

Siret John, probably a fanciful name given to certain varieties of pink to distinguish them from those called Sweet Williams, Dianthus barbatus, $\mathrm{L}$.

SirEet-PEa, a scented pea, Lathyrus odoratus, L.

SIIEET-SEDGE, or -SEG, a plant which, having sword-blade leaves, was comprised under the general name of Segs and Sedges, and fraudulently sold for the sweet cane or calamus aromaticus,

Acorus Calamus, L.

Sweet William, a popular name of a common gardenflower, perhaps from Fr. oeillet, L. ocellus, a little eye, corrupted to Willy, and thence to Willian; a name assigned by IT. Bulleyn (fol. 48) to the wallflower, but by later herbalists to a species of pink; Dianthus barbatus, $\mathrm{L}$.

SWEET WILLOW, from its having the labit of the dwarf willows, and swcet-scented foliage, the sweet gale,

\section{Myrica Galc, L.}

Siweeting, a sweet apple, as contrasted with the crab,

Pyrus Malus, L.

Swine's-bane, see Sowbane.

SwINE'S-CleESS, a cress only good for swinc, Senebicra Coronopus, Poir. 
Swrines-grass, Swynel gruss of the Grete Herluall, Di. swinegres, the knot-grass. Johnston in Jiast. Bord, observes that "Swine are said to be very fond of it," a statement confirmed by writers on agriculture.

\section{Polygonum aviculare, L.}

Swine's-SNout, L. rostrum porcinum, from the form of the receptacle, the dandelion, Taraxacum Dens leonis, $\mathrm{L}$.

Swine Succory, a translation of its Greek name from vos, pig's, and $\sigma e \rho \iota s$, succory, Hyoseris minima, L.

Sword FlaG, from its banner-like flower, and swordshaped leaf, Iris Pseudacorus, $\mathrm{L}$.

Sycamne, that of Luke (ch. xvii. v. 6), the wild fig.

Sycamore, Gr. бикopopos, properly the name of the wild fig, but by a mistake of Rnellius, according to J. Bauhin (Hist. Plant. p. 168), transferred to the great maple. This mistake arose, perhaps, from this tree, the great maple, being, on account of the density of its foliage, used in the sacred dramas of the Middle Ages to represent the fig-tree into which Zaecheus climbed, and that in which the Tirgin Mary, on her journey into Egypt, had hidden herself and the infant Jesus, to avoid the fury of Herod; a legend quoted by Stapel on Theophrastus (p. 220, a), and br Thevenot in his Voyage de Levant, who tells us (part $\mathrm{i}$. p. 265) : "At Matharee is a large sycamore or Pharaoh's fig, very old, but which bears fruit every year, They say that upon the Virgin passing that way with her son Jesus, and being pursued by the people, this fig-tree opened to receive her, and closed her in, until the people had passed by, and then opened again." The tree is still shown to travellers, a few miles N.E. of Cairo. (See Corrper's Apocryphal Gospels, p. 191, note.) The great maple was naturally chosen to represent it, from its making, as II. Gilpin expresses it, an "impenetrable shade."

Aeer Pseudoplatanus, L. 
The Sicamour of the author of the Flower and Leaf (1.54) was some twining shrub, probably the woodbine:

"The hegge also that yede in compas, And closed in all the greene herbere, With sicamour was set and eglatere, and 1.66 , Wrethen in fure."

"The hegge as thicke as any castle wall, That who that list without to stond or go, Though he would all day prien to and fro, He should not see if there were any wight Within or no."

Lonieera eaprifolium, L.

Srndaw, G. sinnau, Da. synav, a word that seems to be derived from $\sin$, ever, and $a a$, water, a name given by W. Turner (b. iii., p. 24) to this plant, beeause "at night it eloseth itself together like a purse, and in the morning it is found full of dew." See Sundew. The lady's mantle,

Alehemilla vulgaris, $\mathrm{L}$.

SYringa or Syring, a name commonly given to a shrub whose stems are used in Turkey for making pipe-stieks, from L. Syrinx, a nymph who was changed into a reed,

Philadelphus eoronarius, L.

by Evelyn to the lilae, that for the same reason was ealled Pipe tree, Syringa vulgaris, L.

TANG, O.N. pang, D. lang, Fris. mar-tag, a word that corresponds to Da. tag, A.S. peece, thateh, from sea-weed laving formerly been used to eover houses, instead of straw. The word has been adopted from one of the northern languages, and refers to a time earlier than the eultivation of eereal grains in high latitudes. Fueus nodosus, I.

TANGLe, seemingly an attempted explanation of Tang, as if it meant entangling, Laminaria digitata, $\mathrm{Ag}$.

TAnsy, $\mathrm{rr}$. athanasie, now eontracted to tanacée and trnaisie, M.Lat. athanasia, the name under whieh it was 
sold in the shops in Iyte's time, Gr. AOavarıa, immortality, referring to a passage in Iucian's Dialogues of the Gods (no.iv.), where Jupiter, speaking of Ganymede, Eays to

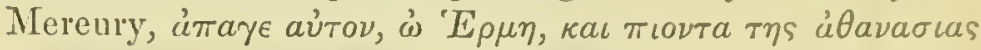

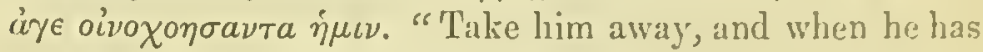
drunk of immortality, bring him baek as eupbearer to us."

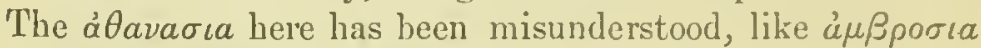
in other passages, for some special plant. Dodoens says (1. i. 2, 16), that it was ealled so, "quod non eito flos inareseat;" which is searcely true. Hyae. Ambrosinus, in lis Phytologia, p. 82, says: "Athanasia ita vocata quia ejus suceus vel oleum extractum eadavera a putredine conservat." Tanacetum, its systematie name, is properly a bed of tansy, and is a word of modern origin.

Tanacetum vulgare, $\mathrm{L}$.

" Goose-, or Wrro-, from its tansy-like leaves,

Potentilla anserina, L.

TARE, an obseure word for which many derivations have been proposed, but none that is satisfactory. In old works it is usually eombined with fytche, as the tare-fytehe.

Lathyrus, Ervum, Ticia.

Tarragon, a corruption of its Lat. specific name, meaning "a little dragron,"

Artemisia Dracunculus, L.

TAsSEl-GRASS, a grass-like plant with bunches of delicate leaves like tassels, Ruppia maritima, L.

Teasel, A.S. tcesel, from tcesan, tease, applied metaphorieally to seratching cloth, Dipsaeus fullonum, L.

Tench-ween, either from its growing in ponds where teneh have broken up the puddling by burrowing in it; or, as Forby says, "from its having a slime or mucilage about it that is supposed to be very agrecable to that fish;"

$$
\text { Potamogeton natans, L. }
$$

Tunt-wont, the wall rue, a fern so called from its having been used as a speeific or sovereign remedy in the eure of rickets, a disease onee known as the Taint. [See Beaum. and 
Fletch., Philaster, A.i. sc. 1.] Threlkeld, under Adiantum album, says: "It is one of the capillary plants, and a specific against the Rickets. For this reason our ancestors gave it the name of Tent-wort."

\section{Asplenium Ruta muraria, L.}

'TETTER-BERRY, from its curing a cutaneous discase called tetters, the white bryony,

Bryonia dioica, $\mathrm{L}$.

TETTER-TroRt, from its curing tetters, the greater celandine,

Chelidonium majus, L.

TeYu-, Teil-, Trl-, or Tiliet-tren, the lime, Fr. tille, formerly spelt teille, a word now confined to the inner bark or bast of the tree, and replaced with the dim. tilleul, from M. Lat. tilliolus, dim. of tilia, Tilia europaea, L.

Thate-cress, from a Dr. Thalins, who published a catalogue of the plants of the Hartz mountains,

Arabis Thaliana, L.

Thape, see Feabe.

Tueve-thonn, O.E. of Pr. Pm. thethorn, A.S. pefe-, pife-, or pyfe-porn, a word that occurs in Wyeliffe's Bible, in the fable of Jotham (Judg. ix. 14, 15), as a translation of the L. rhamnns of the Vulgate, Heb. atad, the name that Dioscorides, as cited by Bochart (i. 752), says that the Carthaginians also called a large specics of rhamnus. It is unknown what bramble Wyclifle meant. T. Wright, in his Manners of the Middlc Ages (p. 296), takes it for the Thape or gooseberry. The context requires a barren or worthless brier, and the monks who commented upon Mesues took it to be the dewberry: "Mowachi qui in Mesuem eommentarios edidere, Rhamnum existimaverunt rubum quendam, qui humi repens, incultisque proveniens, mora cæeruleo potius quam nigro eolore profert." Matthioli (l. i. c. 102). They probably followed an ecclesiastieal tradition, in fixing upon this particular bramble, as representing rhamnus. The word theve seems to be related to such as imply lowliness and subservience, Go. pivan, to 
subjeet, pivi, a female slave, etc. (See Diefenl,ach, I,ex. eomp. ii. 705.) In this view of it Theve-thorn or Thenethorn, as we find it printed, will be the parent of Jev-berry rather than of Thape, and I have no hesitation in referring it to that speeics.

Rubus eresius, $\mathrm{I}$.

Thistci, A.S. pistel, fiom pydan, stab, and the same word essentially in all the kindred languages.

" BLESSED-, from its use against renom,

Carduus benedictus, $\mathrm{I}$.

and the milk thistle,

C. Marianus, L.

Carline-, from its euring Charlemagne's army of a pestilenee, Tabernæm. ii. p. $39 \mathrm{l}$.

Carlina vulgaris, L.

, Cons-, or WAY-, from its growing in fields,

Serratula arvensis, $\mathrm{L}$.

leaves,

and

Serratula arvensis, L.

, Cotton-, from its eottony white stems and Onopordon Aeanthium, L.

Carduus eriophorus, $L$.

" Fullen's-, from its use in dressing eloth,

Dipsaeus Fullonum, L.

" Gentle-, from its eomparatively soft, unarmed, and inoffensive eharaeter, Carduus Anglieus, L. " Holy-, Carduus benedietus, L.

" Melancholy-, from its use in hypoehondria, Carduus heterophyllus, L.

, Musk-, from the seent of its flowers,

Carduus nutans, L.

, OUR LADr's-, from being dyed with her milk,

Carduus Marianus, L.

, St. Barnaby's-, from its season of flowering, Centaurea solstitialis, $\mathrm{L}$.

Scotch-, as being the badge of Seotland, probably" in the first plice any thistle indifferently; but at the present day

Onopordon Aeanthium, and Carduus nutans, L. 
2)

93

Sow-, a mistake of its A.S. name pupistel, Sonchus oleraeeus, L. Stak-, from its star-shaped involuere,

Centaurea Calcitrapa, L.

Thistle upon Thistle, from its numerous priekles ('Threlkeld),

Onopordon Aeanthium, L.

Tuors, A.S. pom, Go. paumnus, and, like thistle, the same word in all the kindred languages, and used with it alliteratively, a word of unknown derivation.

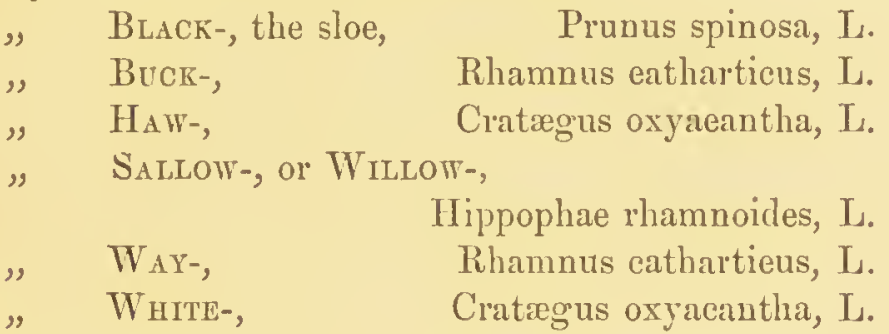

THORN-APPLE, a plant with a thorny fruit,

Datura Stramonium, L.

Thorn-Broon, the furze,

Ulex europæus, $\mathrm{L}$.

Thorow-wax, or Throw-wax, a name given to the plant by Turner, beeause, as he says, "the stalke waxcth throw the leaves," Bupleurum rotundifolium, L.

THREE-FACES-UNDER-A-HOOD, the pansy,

Viola tricolor, L.

Thrifr, the passive participle of threave or thrive, press close together, and meaning the "clustered" pink, so ealled from its growing in chense tufts, Armeria vulgaris, $W$.

Throat-wor', G. halswurz, the Canterbury bell, from being supposed, from its throat-like eorolla, to be a eure for sore throats,

Campanula Trachelium, L.

'Thrui-wort, from thrum, a warp-end of a weaver's web, as in the Teeschale proverb, "He's nae good weaver that leaves lang thrums," a word used by Lyte in deseribing the reed-mace, the head of which he says (b. iv. e. 5:3), "scemeth to be nothing els but a throm of gray wool, or 
flockes, thicke set and thronge togither." The plant lias its name from its long tassel-like panicles of red flowers, the florimer,

Amarantus caudatus, $I$ s.

Thyme, Gr. $\theta v \mu o s$, from $\theta v \omega$, fumigate, and identical with L. fumus, Skr. dhnma, smoke, from dhu, agritate, the name of some odoriferous plant or shrub used in sacrifices, at present appropriated to a genus of labiate plants, and more partieularly to the wild or hill thyme,

Thymus Serpyllum, L.

'TllLet, in $\mathrm{Ph}$. Holland's Pliny, the till or lime tree.

TILLS, abbreviated from lentils. "The eountry people," says Parkinson (Th. Bot. p. 1068), "sow it in the fields for their eattle's food, and eall it Tills, leaving out the Lent, as thinking that word agreeth not with the matter. Ita sus IInevvam." Ervum Iens, L.

Tнмотну-Grass, from its having been brought from New York by a Mr. Timothy Hanson, and introdueed by him into Carolina, and under that name first reeommended to the attention of English agrieulturists,

Phleum pratense, L.

TINE-TARE, a tare or veteh that tines, or eneloses and imprisons other plants. John Heywood, writing of Idleness, says (p. 30 of Bell's edition):

"This vice I liken to a weed That husbandmen hare named tyne,

The which in corn doth root or breed; The grain to ground it doth incline."

Vieia hirsuta, Koch.

and in Linn. Soe. Journ. vol. v. Lathyrus tuberosus, L.

Tithrmali, a name of the spurge tribe in old writers, L. tithymalus, Euphorbia, L.

TOAD-Fuax, from its narrow, linear, flax-like lenres, and its having been deseribed by Dodoens, as "Herba assimilis eum Bubonio faeultatis," and Bubonio having been mistaken for bufonio, from bufo, a toad; as it is 
in the Ortus Sanitatis, ch. 431, where the author, speaking of the Bubonium, says, "dieses kraut wird von etliehen genennet bubouium, das ist hroten-kraut; wann bubo heisset cin krot. Inde bubonium." Linaria vulgaris, L.

"BASTARD-, from its leaves rescmbling those of the preceding plant, Thesinm linophyllum, I.

ToAD-PIPE, from its straight fistulous stalks, and growth in damp places where toads haunt, and croak, and pipe to one another, Equisetum limosum, L.

TodD-sTooL, any of the unwholcsome fungi, supposed to be called so from a belief that toads sit on them. So Spenser, in Sheph. Cal. Dec. 1. 69 :

"The griesly todestool grown there mought I see, And loathed padducks lording on the same."

But as the toad was the impersonation of the devil in popular opinion, perliaps the word may once have had the same meaning with Pixie Stool, and have referred to their origin from devil's droppings. Boletus, Agaricus, etc.

ToBscco, a name of the plant that was adopted by the Spaniards from the Indians of Cuba, but properly the name of the pipe in which it was smoked, the weed itself having been called Cohiba,

Nicotiana Tabacum, L.

'Tolmeneer, 'lolmeiner, or Colmenier, a name given by the herbalists to a variety of the Sweet William. It is spelt by Lyte (b. ii. ch. 7), in three syllables Tol-me-neer, as though it meant "Toll or cntice me near," and Colmenier might in the same way be cxplained as "Cull me near." It is most likely a corruption of D'Almagne, or 7 'Allemagne, as being a pink of Germany.

Dianthus barbatus, L.

Tosaro, its American-Indian name, Sp. tomate,

$$
\text { Solanum Lycopersicum, I. }
$$

Tooti-cress, or ToolH-vioule, from the tooth-like scales of the root,

Dentaria bulbifera, L. 
Tootnwort, from the tooth-like scales of the root-stock and base of the stem, Lathrea Squamaria, L.

Torcil, G. dartsch, the mullein, called sn, because, aceording to Parkinson (Th. Bot. p. 62), and W. Crales (ch. 112), "the clder age used the stalks dipped in suet to burn, whether at funerals or otherwise," a use of the plant indicated by Dioscorides, who (1. iv. 104) speaks of

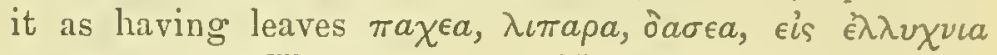
$\chi p \eta \sigma \iota \mu \eta$. See Higtaper. Verbascum Thapsus, L. WATER-, Typha latifolia, L.

Tonnentil, Off. L. tormentilla, from the use of the root in cases of dysentery, L. tormina, or, as Lobel says, from its relieving the pain of toothache,

Potentilla Tormentilla, Sibt.

Tovcri-ME-NOT, from the sudden bursting of its seedpods upon being touched; a phrase that was familiar from the "noli-me-tangere" pictures in Roman Catbolic countries;

Impatiens Noli me tangere, L.

TouCH-WOOD, Polyporus igniarius, $\mathrm{L}$.

Tower-cress, from its having been found growing upon the tower of Magdalen College, Oxford. Its Lat. specific name, turrita, expresses a pyramidal babit of growth, and seems to have been given to it as a translation of its trivial English name, in mistake of its intended meaning.

$$
\text { Arabis Turrita, L. }
$$

Tower-yustard, from the tapering growth of the inflorescence something in the form of a Dutch spire, "om de spits torrewijse oft naeldewijze ghewas van de steelkens," says Lobel (Kruydtboek, p. 262), Turritis glabra, L.

Town-CRESS, A.S. tun-ccerse, a cress grown in a tun, or enclosed ground, as contrasted with the water-and other wild cresscs. Tun seems usually to have meant, as in Iccland at the present day, a close or pasture in connexion with farm buildings. So in Wycliffe's N. Test. (Luke xiv. IS): "I have bought a toune." It is still retained in 
this sense in that very interesting and only half-explored magazine of antiquities, the nomenelature of our fields; and met with oeeasionally as Tun-mead. It is also the Du. tuin, a garden.

Lepidium sativum, L.

Tor-wont, from the little imitations of purses that it bears,

Capsella Bursa, DC.

Travelcer's Joy, from the shade and shelter that it affords by the bower's it forms in roadsile hedges,

Clematis Vitalba, L.

Treacle-Mustard, or -Woruseed, from its being used among 72 other ingredients, in making "Veniee treaele," a famous vermifuge and antidote to all animal poisons, and one that was in great vogne during the Middle Ages; Du. triakel, Off. L. theriaca, from Gr. Onpıov, a small animal. It was so named from the vipers that were added to the Mithridate by Andromaelus, physieian to the Emperor Nero.

"Andromaehus a voulu ehanger le nom de Mithridate en eeluy de Theriaque, à eause des vipères, auxquelles il a attribué le nom de $\theta \eta \rho \iota \nu$, et lesquelles il a ajouté pour la base prineipale de eette eomposition." - Chares, l'histoire des animaux, ete., qui entrent dans la Theriaque. Paris, 1668. See also Heberden's Antitheriaea.

This remedy, triacle, as it was ealled, was the souree of many popular tales of soreerers eating poison, and was retained in the London Pharmaeopeia till about 100 years ago. It was to eure "all those that were bitten or stung of venomous beastes, or had drunk poison, or were infeeted with the pestilenee. The name has extended to Persia, where opium is ealled Teryak. Vambéry (Central Asia, p. 428). See Pr. Pm., v. Treacle. Erysimum eheiranthoides, L.

\section{'Treacle, Poor-man's-, \\ Allium sativum, L.}

TreE, A.S. treow, a word in whieh we find very mueh mixed up in different languages the meaning of a living tree, timber, and an oak-tree espeeially: Skr. druma, druta, 
dru, tree, düru, wood; Zend. dru; Gr. Sopv, both a sprearshaft and a tree, $\delta \rho v s$, an oak and a tree grencrally ; Sliav. drevo and dervo, both wood and tree: Alban. dru, word; Wel. dar, derw, oak; Gael. durach; Gro.trin, A S. trons, Da. trä, both wood and tree. These words seem ts lue related to Skr. dliruva, Zend. drva, firm, O.II.G. triu, true. It is eertainly remarkable that at the early periorl of the first formation in Asia of our eommon mother-langruare, and long before the invention of stecl, so hard a wood as that of the oak should have been so commonly used, as to have beeome synonymous with timber generally. Yet the most aneient boats that have been discovered are of this tree, hollowed out with the aid of fire and tnols of stone.

Trefort, L. tria foliola, three-leaflets, a name given more partieularly to the elovers, Trifolium, L.

Trembling Poplar, the aspen, from its quivering leaves, Populus tremula, L.

Trifroly, of Shalsspeare's Cephalus and Proeris, TriFOLIE of others, a trefoil, so ealled from its three leaflets.

Trinity, see Herb Trinity.

Trip Madai, in Sharroek, p. 143, Trich-Madas, Fr. trippe madame, eorrupted from triacque madame, a plant used as a treacle or vermifuge, Sedum reflexum, $\mathrm{L}$.

Troll-FLower, the globe-flower, from Sw. troll, Da. trold, Fris. trol, a malignant supernatural being, a name eorresponding to Seoteh Witches Gowan, and giren to this plant on aceount of its aerid poisonous qualities,

Trollius europeus, L.

Truelove, ineorreetly so spelt for Trulore, a plant ealled so from its four leaves being set together in the form of a trulove-, or engaged lovers' knot, sueh as is seen in eoats of arms where the wife's is quartered with her husband's; from Da. trolowet, betrothed, of tro, faith, and lore, promise, O.N. trolofad, and not from faithfulness in lore 
with whieh it has no etymologieal eonnexion;

Paris quadrifolia, L.

Trufrle, in Parkinson and Dale TrubBes, It. tartuffola, dim. of tartufo, from L. terre tuber, Tuber eibarium, Sibt.

Tulip, in old works Tulipas, a word that in Turkish means "turban," Pers. dulbend, from its rieh and varied colours, and its shape resembling that of an inverted cap,

Tulipa Gesneriana, L.

Tunhoor, from A.S. tun, a court or garden, Du. tuin, and hufe, a crown, a translation of Gr. $\sigma \tau є \phi a \nu \omega \mu \alpha \gamma \eta$ s, and L. terre corona, the ground ivy,

Nepeta Glechoma, Benth.

Turk's CAP, in Parkinson's Paradisus, the tulip, a translation of its Oriental name. See T'ulip.

Turxip, L. terre napus,

Brassica Rapa, L.

Turnsole or Tornsole, a name erroneously given in some old works to the wartwort, from its being supposed to turn its flowers towards the sun, Fr. tournesol,

Euphorbia helioscopia, L.

TUSSACK-GRASS, from its growing in thiek tufts or tussocks, Aira cespitosa, L.

Tuts.s, in old works Tutsayne, Fr. toute-saine, allwholesome, a word that Gerarde (p. 435), Nemnich, and others derive from its "healing all." Thus Lobel tells us (Kruydtb. pt. i. p. 768), that "it is ealled by the common people in France Toute saine, because, like the Panacea, it cures all sicknesses and diseases." This idea has probably been suggested by its M. Lat. name Androscemum, Gr. of

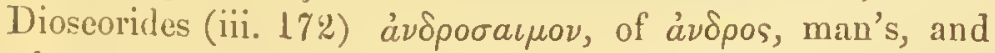
aipa, blood, a name given to it in reference either to the claret colour of the juice of its ripc capsule; or the bloodstain left on the fingers after rubbing the flower, as Fuehs explains it; or more probably to an unguent made from this and a elosely-allied species, of which Gerarde says (p. 433) : "The leves, floures, and seeds stamped, and put 
into a glasse with oile olive, and set in the sunne for certain weekes, doth make an oile of the colour of blood, which is a most pretious remedy for deep wounds, and those that are thorow the body."

Hypericum Andros:emum, L.

TWAY-BLADE, from its two loot-leaves,

Listera ovata, $\mathrm{I}$.

Twice-writhen, L. bistorta, Polygonum Bistorta, L.

TwIG-RUSH, from its tough, twiggy, branching growth,

TwITCH, see QUITCH-GRASS.

Cladium Mariscus, L.

Twopence, see Herb Twopence.

TwOPENNY-GRass, so called by Turner from its pairs of round leaves "standyng together of ech syde of the stalke lyke pence," Lysimachia Nummularia, L.

UNSHOE-THE-HORSE, It. sferra-cavallo, from its horseshoe-shaped legumes being, upon the doetrine of signatures, supposed to have the power of making horses easi their shoes. "Wann die Pferde auf der Weide gehen, und sie auf diess kraut oft treten, fallen ihnen die Hufeisen bisweilen ab." Tabernæm. ii. p. 230.

Hippocrepis comosa, L. says, p. 79, ed. 1611 :

"Horses that, feeding on the grassie bills, Tread upon Moonwort with their hollow heels, Though lately shod, at night go barefoot home."

Botryehium Lunaria, Sw.

UPSTART, the meadow saffron, from its flowers starting up suddenly from the ground, without first putting out leaves,

Colchicum autumnale, $\mathrm{L}$.

VALERIAN, L. valeriana, a name of uncertain origin, Taleriana officiualis, L. 
VELVET-DOCK, the mullcin, from its large soft leaves,

Verbascum Thapsus, L.

VeLveT-FLower, the love-lies-bleeding, from its crimson velvety tassels,

Velvet-Leaf, Amarantus caudatus, L. Lavatera arborea, L.

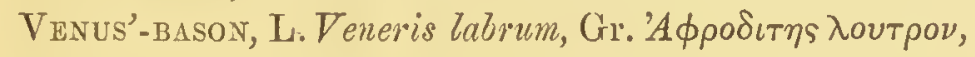
the teasel, so named after the goddess of beauty, from the hollows formed by the united bases of the leaves bcing usually filled with water, that was used, says Ray, "ad verrucas abigendas," to remove warts and freckles,

Dipsacus sylvestris, L.

Venus'-COMB, from the slender tapering beaks of the seed-vessels being set together like the teeth of a comb, Scandix Pecten, L.

Venus'-HaIr, the maidenhair fern, Adiantum, L.

Venus'-LOOKING-GLASS, from the resemblance of its flowers set upon their cylindrical ovary to an ancient round mirror at the end of a straight handle. The name is given by Spenser (F. Q. iii. i. 8) to a magic mirror, in which a lady might see her destined husband.

Campanula hybrida, $\mathrm{L}$.

VerNaL-GRass, from its early flowering, Anthoxanthum odoratum, L.

Vervain, Fr. verveine, L. verbena,

Verbena officinalis, L.

Vetch, or FEтch, or Fitch, It. veccia, L. vicia, related to vincire, bind, as the G. wicke to wickeln, from its twining habit. Used absolutely it means the common vetch,

Vicia sativa, L.

$\begin{array}{ll}\text { " } & \text { Bitter-, } \\ \text { " } & \text { Grass-, } \\ \text { " } & \text { Horse-shoe, } \\ \text { " Kidney-, } & \text { Milk-, } \\ \text { ", Tare-, }\end{array}$

Vicia Orobus, DC.

Lathyrus Nissolia, L. Hippocrepis comosa, L. Anthyllis vulneraria, L. Astragalus glycyphyllos, L. Vicia, L. 
Vetchling, a spurious vetch, Lathyrus pratensis, Id.

VINE, Fr. vigne, L. vinca, adj. of vinum, winc, as licing the wine-shrub, G. wein-relse, Gr. oivos. Turner and sone other old writers spell it vynde, from confusion with A.S. winde. The first syllable of vinum and vitis is probably a radieal wi or mi, whence $\mathrm{L}$. viere, twist, with, withy, etc., and given to the vine in reference to its twining halsit.

Vitis vinifcra, $\mathrm{L}$.

VIOLET, It. violetta, dim. of L. viola, which itsclf is a dim. of iov; in botanical nomenclature now confined to the genus to whieh the pansy belongs, but by ancient writers extended to many other very different plants, especially scented ones. Indeed Laurenberg in Appar. Plant. says (p. 77) : "Videntur mihi antiqui suaveolentes quosque florcs generatim Violas appcllasse, cujuscunque etiam forent generis." Even to the present day we retain it in the popular names of several plants of very different orders. Used absolutely, it means the genus Viola, $\mathrm{L}$.

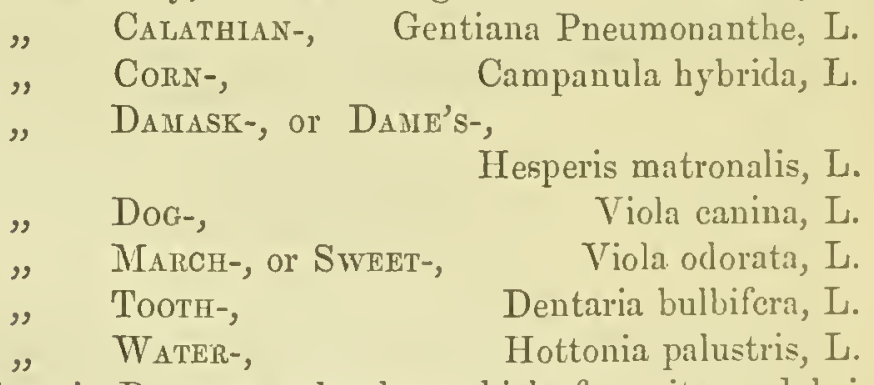

Viper's Bugloss, a bugloss which, from its seed bcing like the head of that reptile, was supposed, on the dnctrine of signatures, to cure its bite. Thus Matthioli (l. iv. c. 69): "In Echio, herba contra viperarum morsus celeberrima, natura semen viperinis capitibus simile procrearit."

Echium vulgarc, L.

VIPER-GRASS, I. viperaria, because, according to Monardus, a physician of Scville quoted in Parkinson's Th. Bot. (p. 410), "a Moore, a bondslave, did helpe those that were 
bitten of that renomous beast, the viper, which thcy of Catalonia called Escuerso, with the juice of this herbe, which both took away the poison, and healed the bitten place very quickly, when Treaklc [Theriaca] and other things would do no good." Its Italian and offieinal Latin name, scorzonera, is derived from It. scorzone, a venemous serpent, popularizcd into a word that would seem to mean " hlack rind," scorza nera.

Scorzoncra edulis, Mn.

Virein's Bower, a shrub so named by Gerarde, as fitting to be a bower for maidens, and with allusion, perhaps, to Queen Elizabeth, but not, as we might be tempted to imagine, to the Virgin Mary in a riposo, or resting scene on the way to Egypt, the frequent subject of pictures,

Clematis Vitalba, L.

Wagwart, a West-country term supposed to mean wagwanton, $\mathrm{Fr}$. in Clusius (p. cexviii), amouretles tremblantes, the quaking-grass, so called from its quivering spikelets,

Briza media, L.

WAKE-PINTLe, a name given in Florio and Torriano's Dictionary as the translation of Ital. Aro, and apparently identical in its meaning with Wake-robin, and Cuckoo-pint, the wake being, like cuckoo, a modern form of A.S. cwic, cucu, and Low. Gicrm. quek, alive, and the noun allusive to its supposed aphrodisiac porvers, Arum maeulatum, L.

$W_{A K E}$ RoBIN, from Fr. rolinet, a word of the same meaning as pintle. See Cuckoo-pint and WAKe-Pintle.

Arum maculatum, L.

WALE-wonT, or WALL-WoRT, the dwarf elder, A.S. wealwyrl, from A.S. wal, slaughter, or wealh, foreign, and corresponding to the other names of the plant, Danesblood and Dancwort, which Aubrey, without a shadow of authority for the statcment, tells us were given to it from its growing at a village called Slaughterford in Wiltshire, where it is supposed that an army of Danes was destroyed. In-German walwurz means the comfrey. Ort. San. (e. xcr.). Brunscl. (b. ii. e. xx.). Sambueus Ebulus, L. 
Watnut, or WELsil Nut, A.S. wealh-linut, from vealh, foreign, G. wätsch, O.H.G. walah, J'r. ganye, an adjective used more partieularly of Italy, from whence the tree was introdueed into Northern Europe, Juglans regia, L.

WALL Barlex, a barley that grows about walls, and which seems to have been taken for the specics called by Pliny (l. xxii. e. 25) lolium murinum, mouse-darnel, the murinum of which was confused with murale, and understood as wall-darnel. Thus Tragus explains the name, as given to the plant, "weil es von sich selbst auf den Mavren wächst;" and Turner tells us (part ii. p. 17): "It is ealled of the Latines Hordenm murinum, that is, Wall-barley." See Muuse-barley.

Hordeum murinum, L.

IVall Cress,

Walt Fern, Arabis, L.

WALL-FLower, a plant introdueed from Spain as a $\mathbb{T}$ all Stock-gillofer, which became successively $\mathbb{W}$ all gilliflorer, and Wall-flower. The Gillofer was the French girofier, and under Stock-gillofer was comprehended the Stock, Matthiola incana, as well as the wall-flower.

Cheiranthus Cheiri, L.

Wall Pennywort, from its round leaves, and its usually growing from between the stones of walls,

Cotyledon Umbilicus, L.

Walr Pepper, from its biting taste, Sedum acre, L.

WALL RockeT, from its rocket-like leaves, and growth upon old ruinons walls, Brassica tenuifolia Boiss.

WALL Rue, a fern so called from its rue-like leaves, and growing between the stones of walls,

Asplenium Ruta muraria, L.

WARE, A.S. war, sea-weed generally, Algæ, L.

WARENCE, Fr. garance, M.L. varantia, or verantia, the madder, from vera, true, genuine, Gr. $a \lambda \eta \theta$ ivos, meaning, par excellence, red, the most glowing colour; as in Spanish colorado means not merely tinted, but blood-red;

Rubia tinetorum, L. 


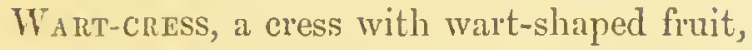

Senebiera Coronopus, Poir.

WART-SPURGE, or WART-WEED, from being used to cure warts,

Euphorbia helioseopia, L.

Water Agrmony,

Bidens tripartita, L.

WATER BETONY,

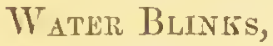

Scrophularia aquatica, L.

Montia fontana, L.

WATER-CAN, Da. autiande, from the shape of the sced vessel, the yellow water-lily,

Nuphar luteum, L.

Titer Ceitokweed,

Water CrFss,

Water Crowfoot,

W ATER Dock,

Water Dropwort,

Water Elder,

Water Featherfoll,

Montia fontana, L.

WATER FENneL,

Water Fers,

Water Flag,

Water Germander,

Water HeMp,

Water Hemlock,

Water Horehound,

Water Horsetall,

Water Lily, Fringed-,

$"$ " $"$ White-,

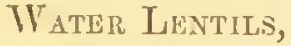

Water Milfoil,

Water Moss,

Water Parsitip,

Water Pepper,

Water Pinpelinel,

Water Plantain,

Water Purslane,

Nasturtium officinale, RB.

Ranunculus aquatilis, L.

Rumex Hydrolapathum, L.

CLinanthe fistulosa, L.

Viburnum Opulus, L.

Hottonia palustris, L.

Enanthe Phellandrium, L.

Osmunda regalis, L.

Iris Psendacorus, L. Teucrium Scordium, L.

Bidens tripartita, L.

Cicuta virosa, L.

Lyeopus europæus, L.

Chara, L.

Villarsia nymphæoides, L.

Nymphra alba, L.

Nuphar luteum, L.

Lemna, $\mathrm{L}$.

Myriophyllum verticillatum, L.

Fontinalis antipyretiea, L.

Sium katifolium, L.

Polygonum Hydropiper, L.

Veroniea Beceabunga, L.

Alisma Plantago, L.

Peplis Portula, L. 
W ATER ROCKET,

Water Scorpion-Grass,

Water Soldier, from its sword-shaped leaves,

TVATER SPIKe,

Water Starwort, from its starry tufts of leaves,

Callitriche, I.

Water Thyme, a name which, from some resemblance of its leaves to those of thyme, has been given to a pestilent weed that chokes our canals, Elodea canadensis, Rd.

Water Torch, in Newton's Herbal of the Bible, the reed-mace, of which Rob. Constantine, in his Dict. abstrus. vocab., says that its panicle soaked in oil and lighted supplies the place of a torch,

TVATER VIOLET,

Water Wort,

WAY BARLeY, -Bennet-, or -Bent, from its growing by waysides,

Hordeum murinum, L.

Waybread, the plaintain, A.S. wegbrced, Da. vejlred, G. of Ort. San. wegbreyt, and wegbreidt, a word the meaning of which is very uncertain. O. Cockayne (Leechdoms, iii. p. 347) explains it as waybroad. It probably meant "spread on the way." Thus the Ort. San., under Incensaria, says, that it is "beynahet als wegbreidte und rechst auch an den sandigen bergen, und brcitet sich langes die erde."

Plantago major, L.

WAYFARING- or WAYFARER-TREE, from growing in hedges by the road-side, a punning name given to it by Gerarde, as implying that it is "ever on the road,"

\section{Viburnum Lantana, L.}

Way-thors, highway-thorn, G. wegedorn,

Rhamuus catharticus, $\mathrm{L}$.

WEASEL-SNOUT, from the shape of the corolla, the rellow dead nettle,

Lamium Galeobdolon, Crz.

Weed, American River-, a name that, for want of a 
more distinctive one, is now adopted for a pestilent wced that was some years ago introduced with Canadian timber, and now infests our rivers, ponds, and canals. It has hitherto been generally known as "Babington's curse;" a name that conveys a most unjust imputation upon a distinguished botanist, who, except drawing up an able description of the plant, has had nothing at all to do with it.

Elodea canadensis, Rd.

WEePiNG Willow, a tree supposed, from the resemblance of its delicate pendulous branches to long dishevelled hair, the conventional expression of gricf, to be the willow of Psalm cxxxvii. 1: "By the rivers of Babylon we sat down, we wept. We hanged our harps upon the willows." But, althongh it is now found growing wild in those countries, it is believed to have been introduced from China, and not to be the tree of the psalmist.

Salix babylonica, L.

WeLCOME-TO-OUR-House, a term unexplained, perhaps a quibhle on its name, Cyparissias, as meaning "Sip ere ye see us," "help yoursclf to the tankard, without waiting to be asked," Euphorbia Cyparissias, L.

WeLd, Would, or Woold, Sp. gualda, Reseda Luteola, L.

Welsh ONION, G. wälsch, foreign, being a Siberian species, and introduced into England from Germany,

Allium fistulosum, L.

Welsh Poppy, from its growing in Wales, Meconopsis cambrica, DC.

Wharre, a crab, W. chwerw, austere, bitter, Pyrus Malus, L.

WHEAT, a term used in the first place with the meaning of white, wheat being, in contrast to rye, and black oats, and the black barley of Northern Asia, a white grain, A.S. hucete, Go. hraiteis, O.N. hveiti, O.H.G. hveizi, Lith. Kwetys, 
Skr. śvêla, white, the initial s'v answering, as in other cascs, to a German $h u$, and Lith. $k w$, 'Triticum vulgarc, L. , Buck-, G. buchwailzen,

Polygonum Fagopyrum, L. Cow-, sce under Cow-WHEAT.

WHIN, from Fr, guindole, M.Lat. guindolum, a word that generally means a kind of cherry, but in Langucdoc is applied to the jujube, L. ziziphus, a name extended to other thorny and prickly shrubs (see HıP), the furze bush,

Ulex europæus, L.

Ononis arvensis, $L$.

WhiN-BERRY, or WIMBERRY, the bilberry, from its growing on whins or heaths, Vaccinium Myrtillus, L.

Whip-TONGUe, from children using its leaves in play to draw blood from their tongues, Galium Mollugn, L.

White BeaMr-TREe, a pleonasm, as A.S. beam means simply a tree. It is called White Beam from the white down on the young shoots and under surface of the leaves; but Beam-tree, as it is often given, without the White, is a vague and silly term.

Pyrus Aria, L.

White Ben, from Ar. Behen, Silene inflata, $\mathrm{L}$.

WHIте BLOW, a name given to two of our earlicst spring flowers very conspicuous upon walls, and also called Whitlow-grasses, of which White Blow may perhaps be a corruption, Saxifraga tridactylites, L., and Draba verna, L.

Whiте-Botrue, from the shape of the calyx, and in distinction from the bluc bottle, Silene inflata, $\mathrm{L}$.

WHITE-RоOт, or-WORT, its officinal name, the Solomon's seal,

Convallaria Polygonatum, L.

Wнлте Rot, from its being supposed to bane sheep, Hydrocotyle vulgaris, $L$. also, for the same rcason, the butterwort,

Pinguicula vulgaris, L.

White Potherb, in distinction from the black potherb or olus atrum, the lamb's lettuce, Talcrianclla olitoria, L. 
Whiте-тнов, in distinction from the sloe or black-thorn, from its comparatively light-coloured rind. Sec Albespyre.

Cratægus Oxyacantha, L.

White Wild-vine, the whitc bryony, in distinction from the black bryony, L. vitis alba, Plin. (1. xxiii. i. 16), Gr. $\dot{a} \mu \pi \epsilon \lambda o \lambda \epsilon u \kappa \eta, \quad$ Bryonia dioica, L.

WHITLOW-GRASS, a name given to two small spring

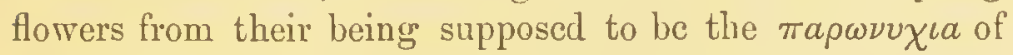
Dioscorides, and useful in the cure of whitlows,

Saxifraga tridactylites, L., and Draba verna, L.

Whitten-tree, a tree so called from its white branches; in Berkshire, the wayfarer-tree, Viburnum Lantana, L. but according to Gerarde (p. 1237), the water-clder, Viburnum Opulus, L.

Whort, or WhORTLEBERRY, the bilberry, corrupted from L. myrta and myrtillus, the names in old vocabularies of the myrtle-berry, a fruit largely imported in the Middle Ages, and used in medicine and cookery, and one that the bilberry much resembles in outward appearance, the $m$ being replaced with $w$ as in many other instances : e.g. in wick from Lat. myxa. In Egenolf's Herbarum Imagines, fol. 31 , b. this plant is represented under the title: mirlus, heidelleer; which is the German name of the bilberry. Vaccinium Myrtillus, L.

Wich or Wiтch Elm, see W тсн.

WiCKen-TREe, see QuiCKen.

Wirdrva, the crab apple, contrasted with the swceting or cultivated sweet apple; as in Spenser (F. Q. b. iii. c. vii. 17): "Oft from the forest wildings he did bring." Pyrus Malus, L.

WILL-OF-THE-WISP, from its sudden and mystcrious growth by night, as if dropped by some phantom,

Nostoc cominune, Ag.

Willian, a name given to the pinks, a genus known to 
old writers as eyes, L. ocellus, Fir. ocillel, a little eye, corrupted to Willie, and thence to William.

"SWEeT-, a flower called so, in allusion perhaps to the hero of a popular ballad, "Nair Margaret and Sweet William," if this was really in existence alove 300 years ago,

Dianthus barbatus, L.

"WILD-, the Ragged Robin, Lychnis flos cuculi, L.

WILLow, a word that seems to express a plianey, a willingness of disposition that well accords with the character of this tree, whose branehes have from time immemorial been used for wieker-work, A.S. wilig, L.G.wilge, Salix, L.

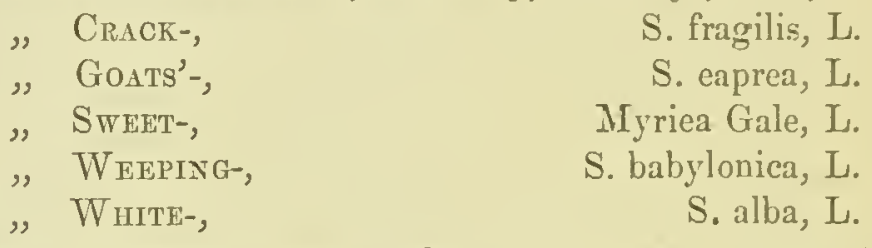

Willow-herb, in W. Coles Willow-WeEd, from its willow-like leaves,

Epilobium, L.

"SPIKed-, Lythrum Saliearia, L.

Willow-thorn, a thorny shrub with the habit of a willow, Hippophae rhamnoides, $\mathrm{L}$.

Willow-Trort, in Sylvester's Du Bartas, p. 79, the loosestrife,

"So willow-wort makes wonted hate shake hands"

Lysimaehia vulgaris, L.

WiND-FLOWER, from Gr. à $\mu \omega \omega \nu \eta$, see ANEMOXY.

Anemoue, L.

WIND-ROSE,

Rœmeria hybrida, DC.

WINDLE-STRAW, A.S. windel-sircow, from vindan, trist, and streow, straw, a grass whose halms are used for platting, Agrostis Spiea renti, $L$. and

Cynosurus eristatus, $\mathrm{L}$.

WINE-BERRY, in the Northern eounties, the red-eurrant, Ribes rubrum, L. 
Wister Aconite, a plant allied to the aeonites, and blowing at midwinter, Eranthis hyemalis, DC.

Winter Cherry, from its red cherry-like berry ripening against the winter,

Winter Cress, Plyysalis Alkekengi, I. Barbarea pr:eeox, RB.

Winter-Green, a name adopted by Turner from the German winter-griun, of the Ortus Sanitatis (c.316). The Danish winter-grönt me:ns the ivy, and it is probable that this latter, the ivy, is the rightful elaimant of the name, as being so eonspieuously green when the trees are most of them bare of leaf.

Pyrola, L.

WIATER-WEED, from its being in winter the weed that spreads most,

Veronica hederifolia, L.

WIRE-BENT, a bent-grass with wiry stems,

Nardus strieta, L.

Writches'-BUtTer, Fris. traal-butter, Sw. troll-smör, from its buttery appearanee, and unaccountably rapid growth in the night, whieh has given rise to a superstitious belief, still prevalent in Sweden, that witehes milk the eows, and scatter about the butter, Exidia glandulosa, Bull.

Wiтch ElM, or - HazeL, a mistaken spelling. See Wror. Witcies' thimble, Silene maritima, L.

Witchen, or Quicken, or Wicken, the rowan-tree, from quycchyn, move (Pr. Pm. p. 4.21), a word related to A.S. cwic, alive. Evelyn looking upon it as derived from witch, supposes it to be so called, because "it is reputed to be a preservative against fascination and evil spirits, if the boughs be stuek about the loouse, or used for walking staffs." It would seen in the first plaee to have meant the aspen, and through some mistake to have been transferred to the rowan-tree. Pyrus aueuparia, Gärt.

Wiтнwixd, A.S. wiðwinde, from wið, about, and windan, wind,

Convolvulus arvensis, $\mathrm{L}$.

W'THY, A.S. wiðige, wiðie, or wiððe, G. wienc, and etymologieally identieal with $\mathrm{Du}$. winde, standing to it in 
the same relation as lithy to linde. Words closely related to it occur in other languinges, as the Iat. vitis and rimen, Gr. itea or yıtea, and Pers. bûl, all derived from a rost vi, the Skr. wê, and having the sense of twisting and twining, the especial use of the osier in all countries. See VINE.

Salix viminalis, L.

WOAD, or WADE, A.S. wad, O.S. mode, O.H.G. veil, in Charlemagne's eapitulary waisila, whence O.Fr. gresde, Fr. guécle, and gaide, M.Lat. guasdinm, guesdium, words derired originally from some ancicnt barbarie language,

WOAD, WILD-,

Isatis tinctoria, $\mathrm{L}$.

Wolfsbane, wolf-poison, a plant so called because, says Gerarde (p. 822), "the hunters which seeke after woolfcs, put the juice thereof into rawe flesh, which the woolfes devoure, and are killed," Aconitum Lyeoetonum, L.

WOLF'S-cLAW, from the claw-like ends of the trailing stems,

Lycopodium clavatum, L.

WoLf's MiLk, from the acrid qualities of its milky juice. Euphorbia, L.

WoodBIne, not a bine that grows in woods, but a ereeper that binds or entwines trees, in old authors called WoopVYNDE and WOODBINDE, A.S. wudu-winde and wudu-bind, from wudn, a tree, and windan, trinc, or bindan, bind, Ger. in Tabermm. ii. 616, Wald-winde, It. Tincibosco, Lonicera Periclymenum, L.

It would seem in some passages to mean the bitterswcet, as in Mids. N. Dr. iv. I.

"So doth the woodbine the sweet honersuckle Gently entwist."

WOOD BLADES, -GRASS, Or - RUSH,

Luzula sylvatica, DC.

Woon Crowroot, of Parkinson, the wood anemony, from its leaves rescmbling those of a crowfoot,

Anemone nemorosa, L. 
TOod Latres, I. lanieola, dim. of laums, a name under which all evergreen shrubs were onee included,

Daphne Iaurcola, L.

Woop LiLr, the lily of the valley,

Convallaria majalis, $\mathrm{L}$.

Wood Nigitshade, the bittersweet,

Solanum Dulcamara, I.

Trood Nut, Corylus Avellana, L.

Wood PEa, from its small pea-like tubers, and its usually growing in woods, Vicia Orobus, DC.

WOOD REED, in distinetion from the pool-recd, Calamagrostis epigeios, I.

WOOD-ROOF, -ROFE, -ROW, -ROWEL, or -RUFF, and agreeably to an old distich :

"Double U, double O, double D, E, $\mathrm{R}, \mathrm{O}$, double $\mathrm{U}$, double $\mathrm{F}, \mathrm{E}$,"

Wooddenowfre, A.S. wude-rofe, from Fr. rone, a wheel, and its dim. rouelle, a little wheel or rowel, the leaves being set upon the stem in verticils that resemble the large rowels of aneient spurs. This is one among several other words that we find to have been adopted into Anglo-Saxon from the French, an occurrence a good deal more frequent than philologists seem to be aware, who, looking upon the former as a pure Germanie language, would trace its vocabulary too exelusively to native roots.

Asperula odorata, L.

Wood Rusin, or -Grass, Luzula sylvatica, DC.

Wood SAGE,

Wood Sorret, or -Sowr, Teucrium Scorodonia, L. Oxalis Acetosella, L.

Trood Sptrge,

WOOD VETCH,

TWOod Vine, Euphorbia amygdaloides, I. Vicia Orobus, DC. Bryonia dioiea, $\mathrm{L}$.

Wood-WAXEN, A.S. wudu-weave, which would secm to mean "wood-grown," a word very inapplieable to a plant 
that is always found in open meadows. It is most probably a corruption of some German name meaning "woadplant," waul-gevä̈chse. It is called in Sloane MS. I 571 , :3, Worlewcx.

WOOLD, a dyer's term, see WELD.

Woolles, the mullein, from its woolly leaf, Fl. vollekinuglt, Ger. of Ort. San. c. 110, Wulkraut,

\section{Verbascum Thapsus, L.}

WorAI-Grass, from its vermifuge qualitics,

Sedum album, L.

WORM-SEED, from its reputed vermifuge qualities,

Erysimum chciranthoides, $\mathrm{I}$.

Worsiwood, a word corrupted from A.S. and O.E. vermod, as in Wycliffe's Lam. iii. 19, G. wermuth, O.H.G. werimnota, O.S. weremede, words which seem to be compounded with G. wehren, A.S. werian, keep off, mod or made, maggot, but which, by an accidental coincidence of sound, have been understood as though the first syllable were worm. L. Diefenbach would prefer to derive it from a Celtic root that means "bitter," Wel. chwerw, Corn. wherow. Be that as it may, it was understood in the Middle Ages as meaning a herb obnoxious to maggots, one to be used to preserve things from them, and given as an anthelmintic or worm medicine.

Artemisia Absinthium, L.

Worts, see Whortleberry, Vaccinium Myrtillus, L.

Worts, in Chaucer a gencral name for cultivated plants, A.S. wyrt, Go. aurts, Skr. vridh, grow; but in Shakspeare (M.W.W. act i. sc. 1), and in Lupton's Notable 'Things, more especially cabbage, being an abbreviation of colencorts, Brassica, L.

Woundwort, from its soft downy lenves having been used instend of lint for dressing wounds,

Stachys Gcrmanica, L.

also, for the same reason, Anthyilis vulncraria, L. 
"Clowy's, sec under Clown.

"KNight's WATER-, a plant that from its swordshaped leaves was supposed, on the doetrine of signatures, to heal sword-wounds,

Stratiotes aloides, L.

WrAck, seaweed thrown ashore, from a Norse or Frisian word connected with Da. vrage, reject, Du, wraken,

"Grass-, a sea-plant with long grass-like leaves,

Zostera marina, L.

WroH-ELM, an elm so named from its wood having been used to make the chests called in old writers vyches, lucches, or whycches, from Fr. huche, A.S. hwacce, a term applied by Sir John Mandeville (c. viii.) to the Ark of the Testimony ; and in a poen called "Cleanness," edited hy Dr. R. Morris, to Noah's Ark, 1. 362 :

"And alle woned in pe whichche pe wylde and pe tame;" but more generally to the boxes used for keeping provisions, as in Hazlitt's Early Popular Poetry, p. 210 :

"His hall rofe was full of bacon flytches, The chambre charged was with vyches Full of egges, butter, and chese."

\section{Ulmus montana, L.}

WrCH-HAZEL, from the resemblance of its leaf to that of the hazel, the wych-elm,

Ulmus montana, L.

YAkR, abbreviated from yarrow, and applied to a very different plant, the spurry, from both having been confused under the name of milfoil, Spergula arvensis, L.

Yarrow, the milfoil, A.S. gearwe, L.Ger. geruwe, O.H.G. garawa, O. Fris, lerva, G. garbe, a word that seems to have been properly the name of the vervain, hicrabotane, the

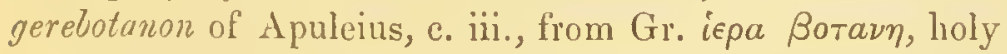
herb, with which and with the betany we learn from a couplet in Maecr, c. 58, that it was associated in its ruluerary and other supposed virtues:

"Herbam, cui nomen foliis de mille dederc, Betonicamque pari verbene pondere junge." 
'The initial $h i$ of Greek words has in the Ciermanic languages been usually replineed with $y$ or $j$, and thus, as IJieromymus and Hierosolyma have beeome Jerom and ferusulem, so liera has beeome yarrow. Speaking of $V^{T}$ erluena, Fuchs says, (ed. Basil. fol. 154.2, p. 591): "Jieralotane ider, ricta, quod ea olim apud Romanos domus purgaljatur, familia lustrabatur, Jovis mensa ad saerifieium et epulas verrebatur, et feeiales in saeris lequationibus illa coronahantur, vel, ut Dioseorides inquit, quod in expiationibus suspensa et alligata mire ntilis sit." As at present nnderstood,

YEAST-PLANT, Aehillea Millefolium, L.

Yellow Archangel, see Archangel,

Lamium Galeobdolon, Crz.

YezLow Birdsnest, in eontrast to the wild earrot, that was also ealled Birdsnest,

YeLLOW Bugle,

Yet.low CRess,

YELIOW LOOSESTRIFE,

YEJLLW OX-EYE,

Yellow Purpernel,

Yeliot RattLe,

YELI.OW ROCKET,

Monotropa Hypopitys, L.

Ajuga Chamapitrs, L.

Barbarea preenx, RB.

Lysimachia vulgaris, $\mathrm{L}$. Chrysanthemum segetum, L.

Lysimaehia nemorum, L.

YeLLOW-WEED, a weed or dye-plant used for dyeingr yellow, the term weed being here, as in green-weed, redweed, ete., not the A.S. weod, but the Du. reed, G. rrainl, the weld,

YELLOT-WORT,

Reseda Luteola, L.

Yevering Belis, L. tintinnabuhum terre, said to be so called from a lofty eonieal mountain near Kirk Nerrton in Northumberland, where it has been found growing wild, Prrola seeunda, L.

YEW, or YeUGit, in old authors varionsly spelt EwGH, Jint, Uit, Ewr, and U, A.S. iw, O.HI.G. izca, G. cibe, Sp. and Port. iva, F. if, W. yw, from Mr. Isat. irus, iva, or ium, 
a name applied to several different plants, and of uneertain derivation. Some of the dictionaries allege for it a Celtic iw, green, but there does not appcar to be any such word. It seems to be an abbreviation of aiuga, a misspelling of L. abiga, a plant mentioned by Pliny (b. xxiv. ch. 20), als

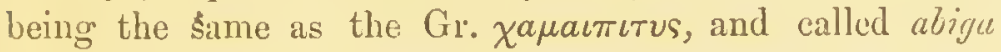
from its causing abortion. Different as are the two words abiga and ajuga in our modern print, the $\delta$ of abiga might be writtell so as to look iike a $v$ or $u$, and the word be read as aurga or ainga, as the dot over the $i$ is placed. From this seems to have been formed iua, under which term the yew and ivy were so inextricably mixed up, that, as dissimilar as are the two trees, there can be no doubt that their names are in their origin identical. How they eame to be attached to them both, is the difficulty. Apuleius (ch. 26), speaking of chamepitys, says, "Græci chamrpityn, Itali abigam, alii cupressum nigram vocant." Brunsfels too says of the chamæpitys (b.i.p. 161), "Ego autem cipressen existimavi." The yer seems to have been taken for this black cypress, and in this way to have acquired the terms abiga, and ajuga, and iua and iva. But we learn from Parkinson (Th. Bot. p. 284) that a weed of corn-fields, the plant that is now called chancepitys, was "called in English Ground pine, and Ground ivie, after the Latin word Iva." This term Ground iry was assigned by others to another small labiate plant (Nepeta Glechoma, B.), which was formerly called Hedera terrestris, and ivy was regarded as the equivalent of hedera, and was subsequently transferred to the Hedera helix, our present Ivy. 'Thus by a train of blunders, Pliny's aliga bccomes ajuga, and ajuga becomes iua or iva. 'This aliga (ajuga, or iua) was, as Pliny tclls us, the samc as the Greek chamcopitys. The yew-tree gets the name of chamcepitys through a remark made by Apuleius, and thereby, as its synonym, that of iua or iva. The ground-pine, from its terebinthinate odour, also gets 
the name of chamcepitys, and thereby, as its synonym, that of iua or iva. But from chama- being equivalent to terrestris, this nume ina or ina passes over to a weed called, from the shape of its leaf and ereeping habit, herlera terrestris, and the equivoeal word hedera conveys it to the shrub whieh thus gets the name of $i v y$. See lvy.

\section{Taxus baceata, $L$.}

YoKE-EL, the hornbeam, from yokes being made of it, Gr. ל̌ Carpinus Betulus, L.

Yorkshire SaNicle, the butterwort, from being, for its healing qualities, ealled by Bauhin (Pin. 24.3) Saniculn, and "growing so plentifully in Yorkshire," as Parkinson tells us (Th. Bot. p. 534), Pinguieula vulgaris, L.

Yoraut, Yernet, or Yuxnut, in the Northern eounties, a dialeetie pronuneiation of Earthnut, Da. jordmüd,

Bunium flexuosum, With.

Youthwort, A.S. conð, a floek, and rotian, rot, mistaken for wort, so ealled from its being supposed to bane sheep, the red-rot, Drosera rotundifolia, L. 


\title{
SYSTEMATIC NAMES OF BRITISH PLANTS,
}

\author{
WITH THE OMISSION OF SUCH AS RAVE NO POPULAR EQUIVALENT.
}

Acer canpestre, L. Maple. Maser-tree.

" Pseudoplatanus, L. Sycamore. Mock Plane. Aceras anthropophora, RB. Man-, or Green Man Orchis. Achillea Millefolium, L. Yarrow. Nosebleed. Milfoil. Sanguinary.

" Ptarmica, L. Sncezewort. Goose-tongue.

, Ageratum, L. Maudlin.

Aconitum Napeluus, L. Monkshood. Wolfsbrue. Aconite. Frial's cap.

Acorcs Calanus, L. Sweet Flag. Sweet Sedge. Actea spicata, L. Baneberry. Herb Christopher. Actinocarpus, see Damasonium.

Adiantum Capiluos, L. Maidenhair. Capillaire. Venus' Hair. Adonis autumials, L. Pheasant's eye. Red Mayd-weed. Rose-a-ruby. Red Morocco.

Adoxa moschateldiya, L. Moscatel. Agoponium Podagraria, L. Goutweed. Ashweed. Herl, Gerard.

Mescules Hippocastanum, L. Morse Chesnut. Finusa Cynapium, L. Fool's Parsley. Asses' Parsley. Dog's Parsley.

Agamicus mescariles, L. Bug Agarie. Flybane.

", Campestris, L. Mushroom.

" Arvensis, Sch. Horse Mushroom.

Agrimonia Elpatoria, L. Agrimony. Egremoino. 
Agrostemin, seo Lycinis.

A griostis ALBA, L. Fiolin.

" " var. stolonifera. Knot-grass.

Agrostis Spica venti, L. Windlestraw.

Aira cespitosa, L. 'Tussaek-gi'ass.

CARYOPHYLLEA, L. Hail-grass.

AJuga Chandepitrs, L. Ground-pine. Forget-me-not. Herl,

Iry. Gout Iry. Field Cypress.

" Reptans, L. Bugle.

Alaria esculenta, Lam. Honeyware.

Alchemilla arvensis, L. Parsley-piert. Breakstone. Pereepier.

" vulgaris, L. Lady's mantle. Lion's foot. Padelion. Syndaw.

Alisma Plantago, L. Water Plantain.

Alliaria officinalis, DC. Jaek-by-the-hedge. Sauee-alone.

Garliek Mustard. Garliek-wort.

Allium ascalonicum, L. Shallot. Seallion. Cibbols.

"Cepa, L. Onion.

Scorodoprasum, L. Rocambole.

Schenoprasum, L. Chives.

vineale, L, Crow Garliek.

URsinuı, L. Ramsons. Bear's Garliek. Buekrams.

Fistulosum, L. Welsh Onion.

PoRRUi, L. Leek. Purret.

Satrvor, L. Garliek. Poor-mar's treaele. Churl's treaele.

Allosorus crispus, Ber. Parsley-fern.

Alnus glutinosus, L. Alder.

Alopecurus Agrestis, L. Blaek Bent. Mouse-tail Grass.

Hunger Grass.

pratensis, L. Meadow Foxtail.

Althexa officinalis, L. Marsh Mallow. Hoek-herb.

" Rosta, L. Hollihoek.

Alyssum maritirum, L. Sweet Alison.

" Saxatile, L. Yellow Alison. 
Amarantus cavdatus, L. Florimer. Love-lies-bleeding. Amaranth. 'Thrnmwort. Velvet-flower.

" Impochondriacus, L. Prinee's feather.

Aybrosia, L. Ambrose.

Amar Majus, L. Bull-twort. Herb William. Bishop's weed. Amigdalus persica, W. Peach. Neetarine.

Axacharis Alsinastrum, Bab. See Elodea canadensis, Rd. Axacrclus Pyrethrum, DC. Pellitory of Spain.

Anagalis arvensis, L. Red Pimpernell. Poor-man's Weather-glass.

Anchusa officinalis, L. Alkanet. Bugloss.

Andromeda Polifolia, L. Moor-wort. Marsh Rosemary. Marsh Holyrose.

Anemone neMorosa, L. Wind-flower. Wood Crowfoot. Wild Anemony.

" Pulsatilla, L. Flaw-flower. Pasque-flower.

" Hepatica, L. Noble Liverwort. Hepatiea. Liverleaf.

Anethum graveolens, L. Dill-seed. Anet.

Angelica Archangelica, L. Archangel.

" Sylvestris, L. Holy Ghost.

Anthenis nobilis, L. Chamomile.

" Cotula, L. Maydweed. Dog's Fennel. Mather. Anthoxanthum odoratum, L. Sweet-scented Vernal-grass. Axthriscus sylvestris, L. IIare's Parsley.

Axthyllis vulneraria, L. Lady's Fingers. Kidney Vetch. Lamb's-toe.

Axtirrinnum mayus, L. Snapdragon. Calves snout. Lion's snap.

Apium graveolens, L. Celery. Smallage. Marsh Parsley. Aquilegia velgaris, L. Columbine. Culverwort. Arabis perfoliata, Lam. Tower Mustard.

, TurRita, L. Tower Cress.

"Tilaliana, I. Wall Cress.

" stricta, Huds. and petras, Lam. Roek Cress. Arbutus Unedo, L. Strawberry-tree. 
Arctium Lappa, I. Burdoek. Hardock. Hurr-\}urr. Arctostapiylos Uva URsi, Spr. Bearberly. Meallerry. Arenaria, L. Sand-wort, or -weed.

Aristolochia Clematitis, L. Birthwort.

Armeria vulgaris, W. 'Thrift. Lndy's eushion. Sea Gilliflower. Cushion Pink.

Artemisia Absinthium, L. Wormwood.

" Dracunculus, L. Tarragon.

" vUlgaris, L. Mugwort. Motherwort.

" Aвrotanom, L. Southernwood. Boy's love. Lad's love. Old Man. Averoyne.

Arum macolater, L. Cuekoo-pint. Lords and Ladies. Wake-pintle. Wake Robin. Aaron. Bloodyman's-finger. Calves-foot. Rampe. Stareh-wort. Arundo Phragmites, L. Reed. Pole-reed. Spires. Asarum europaun, L. Asarabaeea. Fole-foot. Hazel-wort. Asparagus officinalis, L. Sparrow-grass. Sperage. Asperdgo procumbens, L. German Madwort. Asperdla cynaxchica, L. Squinaney-wort.

, odorata, L. Woodroof.

Aspidium Lonchitis, Sw. Holly-fern.

" aculeatum, Sw. Prickly Shield-fern.

" 'Thelypteris, Sw. Marsh-fern.

" Oreoptreris, Sw. Sweet-fern. Mountain-fern.

" Filix ins, Sw. Male-fern.

Aspleniom, L. Spleenwort. Miltwaste.

" Filix foenina, Bern. Lady-fern.

" marindr, L. Sea Spleenwort.

, Trichomanes, L. Black Maidenhair.

", Reta noraria, L. Wall Rue. Tent-wort. Aster Tripolidu, L. Sharewort. Sea Starwort.

Tradescant, L. Michaelmas Daisy. Astragalds glycyphyllos, L. Liquorice Veteh. Atriplex hortensis, L. Oraebe, " Portulacoides, L. Sea Purslane.

" Patdla, L. Delt Oraeh. Lamb's Quarters. Fat hen. 
Atrole Belladoxna, L. Deadly Nightshade. Dwale. Deatl's-herb. Great Morel.

Avena sativa, L. Oat. Haver.

" KUDA, L. Pill-eorn.

" Fatua, L. Wild Oats. Diake.

Ballota NigRa, L. Flaek Horehound.

Balsamita vulgaris, L. Aleeost. Maudlin. Costmary.

Barbarea Precox, RB. Belleisle Cress.

" velgaris, RB. Winter Cless. Yellow Roeket. St.

Barbara's Cress. Land Cless.

Bartesia alpina, L. Poly-mountain.

Odontites, L. Eyebright Cow-wheat.

Berlis perenvis, L. Daisy. Brnisewort. Herb Margaret.

Marguerite.

Berberis vulgaris, L. Barberry. Pipperidge.

Beta maritima, L. Beet. Mangel-wurzel.

Betula alea, L. Bireh.

Bidexs cerved, L. Nodding Bur Marigold.

" tripartica, L. Trifid Bur Marigold. Water Agrimony, Water Hemp.

Blachnum bolieale, Sw. Hard-fern.

Borago officinalis, L. Borage.

Botrychium Lunaria, Sw. Moonwort. Lunarie. Plantage. Brassica oleracea, L. val's. Cabbage. Cauliflower. Broeeoli.

Cale. Savoy. Kohl-rabi. Bore-eole.

$"$ Cumpestris, L. var. Rapa, Rape. Coltza. Mype.

" " var. Napus. Turnip. Kinolles. Navew, liutabaga. Swede.

$"$ ALla, Boiss. Mustard.

Sixupistrum, Boiss. Charloek. Wild Mustard.

Chedloek.

" Nrgli, Boiss. Blaek Mustard. Senvy.

" TFxuffolis, Boiss. Wall Roeket.

Briza medi, L. Quaking-grass. Wagwants. Lady's hair.

Dodder-grass. Maidenhair-grass. Shaker. Pearl-grass. 
Bromus moldis, L. Lobgrass. Oatgrass.

" STrimilis, L. Diake.

Bryonia MIOICA, L. White Bryony. White Wild Vine.

Bunida flexuosum, W. Arnut. Yor-nut. Jur-nut. Jig-nut, Mandrake. Tetter-berry. Hogr-nit. Earth-nut. St. Anthony's-nut.

Bupleurum rotundifolium, L. Thorowax. Hare's car. Butonus exbellatus, L. Flowering Rush.

Buxus sempervirens, L. Box.

Cakile maritima, L. Sea Rocket.

Calainagrostis Epigeios, Roth. Wood-reed.

Calamintila Clinopodidm, Benth. Stone Basil. Field Basil. Horse Thyme.

" Acinos, Clair. Basil Thyme.

Calendela officinalis, L. Marigold. Golde. Gools. Gowan. Ruddes. Marybuds.

Callitriche aqdatica, Sm. Star-grass.

Caltha paldestris, L. Marsh Marigold. Brave Bassinets.

Boots. Meadow Bouts. Mare-blobs.

Camelina sativa, L. Gold of pleasure. Cheet. Oil-seed. Campanula Rapenceles, L. Rampion. Corentry Rapes. " RotUndifolia, L. Harebell. Lady's Thimble. Witehes' Thimble.

" myrrida, L. Venus' Looking-glass. Lady's Lookingglass. Corn Violet.

" Trachelium, L. Canterbury Bells. Throat-wort. Haskwort. Mereury's Violet. Mariet. Coventry Bells. Cannabis sativa, L. Hemp. Gallow-grass. Neekreed. Cantharellus cibarius, Fr. Chantarelle.

Capsella Bdrsa pastoris, L. Shepherd's poueh. Casse-weed.

Clappedeponeh. Toy-wort. Piekpurse. Poor-man's Parmaeetty.

Cardamine amaka, L. Bitter Cress.

" priatensis, L. Lady's smock. Cuekoo-flower. Mteadow Cress. Spinks. 
Caniduds benedictus, I. Blessed Thistle.

, Eriophorus, L. Cotton Thistle. Friar's crown.

, heteropitruus, L. Melaneholy Thistle.

, Laxceolatus, L. Spear Thistle. Bur Thistle.

" Marianus, L. Milk Thistle. Lady's Thistle.

, Nutans, L. Musk Thistle. Seoteh Thistle.

Carfi, L. Sedge.

" paniculata, L. Hassoeks.

" armania, L. Stare.

" PANiCEA, L. Carnation-grass.

Carlina vulgakis, L. Carline Thistle.

Carpinus Beturus, L. Hornbeam. Hurst Beeh. Hard-beam. Yoke Elm.

Carthantes tinctorius, L. Safllower.

Carua Carut, L. Carraway.

" Bulbocastanox, L. Earth-nut. Pig-nut. Arnut.

Carcalis Anthriscus, Huds. Hedge Parsley. Hemloek Chervil. Rough Cieely.

, Daucoides, L. Bur Parsley. Hedgehog Parsley. Hen's foot.

Cexomyce pridida, Ach. Cup Moss.

Centaurea Cyanes, L. Bluebottle. Corn-flower. Blue Blaw. Hurt-sickle.

" Nigra, L. Knapweep. Horse-knob. Hard-head. Mat-

fellon. Bullweed. Churl's head. Loggerbead.

, Caicitrapa, L. Caltrop.

, solstitralis, L. St. Barnaby's Thistle. Star Thistle. Centranthus ruber, DC. Red Valerian.

Ciatureules maxtus, L. Chaff-weed.

Cerastuuar vulgara, L. Monse-ear Chiekweed.

Ceratophylum, L. Hornwort.

Cercis Siliquastrum, L. Judas-tree.

Ceteracil officinarum, Willd. Ceteraeh. Sealy-fern. Fingerfern. Miltwaste.

Cetraria islandica, Aeh. Teeland Moss.

Cinsephullus symestre, L. Cow Parsley. Wild Cicely. 
Criara, L. Water Horsetail. Stone wort. Chemantius Chemin, L. Wall-flower. Blecding-heart.

Bloody warrior. Wild Cheir. Chevisaunce.

Cher.idonium majus, L. Celandinc. Swallow-wort. Tetter-wort. Chenopodium, L. Goosefoot.

" AlBum, L. Frostblitc.

" Bonus Henricus, L. Allgood. Good King Henry.

Blite. English Mercury.

" POLYSPERMUd, L. Allseed.

, Rubrum, L. Pig-weed. Sowbane.

" Vulvaria, L. Dog's Orach. Stinking Orach.

" ambrosiomes, L. Oak of Cappadocia. Oak of Jerusalem.

" Botrys, L. Ambrose.

Cherleria sedoides, L. Cyphel.

Chlora perfolita, L. More Centory. Yellow-wort.

Chondrus crispus, Lyn. Carrageen Moss. Irish Moss.

Chrysanthejum Ledcanthenum, L. Moon-wort. Ox-ege.

Moon Daisy. Maudlin-wort. Midsummer Daisy.

3 Segetui, L. Bigold. Boodle. Goldins. Gools. Ruddes.

Yellow Ox-eye. Corn Marigold.

Parthenium, L. Feverfew.

Chrysocona Linosiris, L. Goldilocks.

Chrisospleniur, L. Golden Saxifiage.

Cicer arietindu, L. Garavauce. Gram. Chick pea.

Cichorium Intybus, L. Succory. Chicory.

" Endivia, L. Endive.

Cicuta virosa, L. Water Hemlock. Cowbane.

Circea Lutetiana, L. Enchanter's Nightshade.

Cladiom Mariscus, L. Twig-rush.

Cladonia rangiferina, Hff. Reindeer Moss.

Clematis Vitalba, L. Virgin's bower. Lidy's bower. Oldman's-bcard. Traveller's joy. Bind-with. Hedgevine. Love. Smokc-wood. Climbers.

Cocillearia officinalis, L. Scurvy-griss. Spoonwort.

, Armoracia, L. Horse Radish. 
Colchicum autumale, L. Meadow Saffion. Naked Ladies. Upstart.

Comarum, sce Potentilla. Conferva egagropila, L. Moorballs. Conium inculatur, L. Hemlock. Herb Bennett. Convaliaria iajalis, L. Lily of the Valley. Liry-eonfancy. May-lily. Lily-eonvally.

" Polygonatur, L. Solomon's seal. Ladder-to-heaven. Lady's seal. Seal-wort. White-root.

Convolvulus arvensis, L. Bindweed. Bearbind. Withwind. Cornbind.

" Sepruar, L. Hedge-bells. Lady's nightcap. Campanelle. "Soldantlla, L. Sea-bells, -Bindweed, or -Withwind.

Corallorhiza invata, RB. Coral-root.

Coriandrua sativua, L. Coriander. Col.

Corvus sangunea, L. Dogwood. Gadrise. Dog-eherry. , Suecica, L. Dwarf Honeysuckle.

Corrigiola littoralis, L. Strapwort.

Corydalis tuberosa, DC. Holewort. Hollowort.

Corylus Avellana, L. Hazcl. Stoeknut. Filbert. Cobnut. Cotrledon Uabilicus, L. Navel-wort. Kidney-wort. Hipwort. Lady's navel. Wall Pennywort.

Crambe maritma, L. Sea-kale. Sea Cabbage.

Crateges Oxyacantha, L. Hawthoin. Quickset. Whitethorn. May. Albespyne.

Crepis, L. Hawksbeard.

Crithifum maritimum, L, Samphire.

Crocus satives, L. Saffron.

Cucejis Melo, L. Melon.

" Satrvus, L. Cueumber.

Cucuriata Pepo, L. Gourd. Pumpkin.

" ovifera, W. Vegctable marrow.

Cominum cransun, L. Cummin.

Cuscuta furopat, L. Doddel, Laly's laces. Brille's laces.

IIcll-wced. Devil's guts. Strangle-tarc. 
Crchamen europaum, L. Sowbread. Cyclamen. Crinara Scolymus, L. Aitichoke. Cinara Cardunculus, L. Cardoon.

Cxnodon Dactilan, L. Doob. Dog's tooth.

Cinoglossuar officinale, L. Hound's tongue. Dog's tongue. Criosurus cristatus, L. Dogstail.

" ECinnatus, L. Cock's- comb grass.

Cxperus longus, L. Cypress-root. Swect Cypress. Galangalc. Crpripedium Calceolus, L. Lady's slipper.

Crstopteris fragilis, Bern. Bladder-fern.

Cxtisus Laburnum, L. Laburnum. Golden chain.

Dactylis glomerata, L. Orehard-grass. Dew-grass.

Damasonidm stellatum, P. Star-fruit.

Daphne Laureola, L. Spurge-, or Wood-, or Copse-Lanrel. Lowry. Daphne.

" Mezereon, L. Mezereon. Spurge Olive.

Datura Stramonidm, L. Thom-apple. Dewtry.

Daucus Carota, L. Carrot. Bee's nest. Dauke.

Delphinium, L. Larkspur. Knight's spurs.

" Grandiflorum, L. Bee Larkspur.

"Staphisagria, L. Stavesacre.

„ Consolida, L. Consound.

Dentaria BUlbifera, L. Tooth Violet. Coral-wort.

Dianthus, L. Pink.

, Armeria, L. Deptford Pink.

" Deltoides, L. Maiden Pink. Meadow Pink.

, Crsius, L. Cheddar Pink. Cliff Pink.

" Barbatus, L. Sweet William. Sweet John. Tolmeiner.

" Prolifer, L. Childing Pink.

" Caryophylud, L. Carnation. Clote Pink. Gilliflower. Piggesnie. Sops-in-wine.

Digitalis purpurea, L. Foxglove. Finger flower.

Digrapitis arundinacra, P.B. Lady's garters. French-girars.

Ribbon-grass.

Diotis maritima, Dsf. Sea Cudweed. 
Dirsacus fullonur, L. Fuller's teasel.

" Pilosus, L. Shepherd's staff, or -rod. *

", sylvestris, L. Teasel. Venus' bason.

Draba verna, L. Whitlow-grass. Nail-wort. White Blow. Drosera rotundifolia, L. Sundew. Lustwort. Youthwort. Drias octopetala, L. Mountain Arens.

Echidu vulgare, L. Viper's-bugloss.

Elatine Hydropiper, L. Water Pepper. Water-wort.

Elonea canadensis, Rid. Ameriean River weed. Water Thyme.

Elyuts arenarius, L. Lyme-grass.

Enietrom nigrom, L. Crowberry. Crakeberry.

Epilobidm hirsutum, L. Codlins and Cream. Willow-herb. " angustifolium, L. Freneh willow. Persian willow. Rose-bay.

Epimedium alpinum, L. Barren-wort.

Eripactis, RB. Helleborine.

Equisetuai arverse, L. Bottle-brush.

" hyemale, L. Dutch-rush. Shave-grass. Pewter-wort. Seouring-rush.

" Lmosum, L. Paddock-pipes. Toad-pipes.

"Teluateja, Ehr. Great Horsetail.

Eraxthis hymalis, DC. Winter Aeonite.

Erica Tetralix, L. Cross-leaved Heath.

" cinerea, L. Grey Heath. Seotch Heatl.

" vulgaris, L. Ling. Henth. Grigg.

", vagaxs, L. Cornish Heath.

Erigeron acre, L. Blie Fleabane.

Eriocaulon septaxgulate, L. Pipe-wort.

Eriotiorui, L. Cotton-rush.

" Vaginatum, L. Iare's-tail-rush. Moss-erops.

Erodicn moschatum, L'Her. Heron's bill. Muscovy. Musk.

Pink-, Powk-, or Pick-needle.

Eiveri Lexs, L. Lentil. Tills.

" Eivilia, L. Ers. Pigeon's pea. 
Eryogium maritimum, L. liryngo. Sea Ilolly. Ersimla-chemanthomes, L. Treacle Mustard.

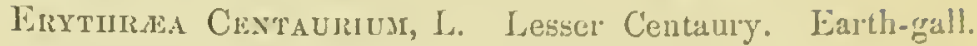
Christ's ladder'.

Euratorius cannabinum, I. Ifemp Agrimony. Holy rope. Eurmorbia helioscopia, L. Sun-spurge. Turnsole. Wartweed. Devil's milk. Cat's milk. Littlegoorl. Churustaff.

" Lathrris, L. Wild Capers.

" Cyparissias, L. Weleome-to-our-house.

Euphrasia officinalis, L. Eyebright. Euphrasy.

Ifvonyuts Europaus, L. Spindle-tree. Priek-wood. Skewerwood. Gadrise. Louse-berry-tree.

Exidia glandulosa, B. Witehes' butter.

" Auricula Jude, Fr. Jew's ears.

Fagus sylvatica, L. Beeeh. Buek-mast.

Festuca pratensis, L. Fesene-grass.

Ficus Carica, L. Fig-tree.

Filago, see Giaphalidil.

Filix, Fern.

Faniculua vulgare, Gürt. Fenuel.

Fontinalis antipyretica, L. Water Moss.

Fragaria vesca, L. Strawberry.

Frankenia latis, L. Sea Heath.

Fraxinus excelsior, L. Ash.

Fritillaria Meleagris, L. Fritillary. Guinea hell. Cheekered lily. Snake's head.

Fucus nodosus, L. Kelpware. Tang. Kinob-tang.

natans, Turn. See Sargassum.

Fumaria officinalis, L. Fumitory. Earth-smoke.

Fungus, L. Mushroom. Toadstool. Paddock-stool.

Gagla lutea, Ker. Yellow Star of Bethlehem.

Galantiuns nivalis, I. Snowdrop. Fair Mlaids of February. Purification-fluwer. 
Galeopsis Ladanum, L. Red Hemp-nettle.

Tetranit, L. Hemp-nettle. Bee-nettle.

Galiem Crucrata, Seop. Crosswort. Maywort. Golden Mugweet.

"Moldugo,L. Whip-tongue. White Bedstraw.

„ verum, L. Lady's Bedstraw. Maid's hair. Petty

Mugget. Cheese Rennet.

"Aparine, L. Cleavers. Cliders. Goosegrass. Goosebill.

Harif. Goose-heiriffe. Loveman. Beggar's liee.

Serateh-weed. Cateh-weed. Grip-grass.

Gastrididu lendigerum, P.B. Nit-grass.

Geaster, B. Earth-star.

Gexista tinctoria, L. Base-broom. Dyer's Green-weed.

Wood-waxen.

" axglica, L. Petty Whin. Needle Furze. Moor-, or' Moss-Whin.

Gextiana, L. Bitterwort. Felwort. Gentian.

" Pxecronantue, L. Autumn bells. Calathian Violet.

Lung-flower.

Grraniun pratexse, L. Meadow Cranesbill. Crowfoot Cranesbill.

" Robertianum, L. Herb Robert. Red-shanks.

„IOLLE, L. Dove's foot.

, Columbixur, L. Culverfoot.

Geum undayum, L. Avens. Herb Bennet.

" Rivale, L. Water Avens.

Glaidolus comannis, L. Gladiole. Coin-flag.

Glaccium luteum, L. Horned Poppy. Sea Poppy.

Gladu marima, L. Blaek Saltwort. Sea Milk-wort.

Griceria flutans, RB. Mauna-giass.

Ginapilaliuar dioicua, L. Cat's-foot.

., Margaritaceum, L. Everlasting.

" Luteo-Albun, L. Jersey Livelong.

„, uliginosum, L. Cudweed. Chafe-weed. Cotton-weed.

" Germanicum, L. Herb Impious. Childing Cudweed.

Goodrelia repexs, RB. Creeping Satyrion. 
Gyrophora vellea, Aeh. Rock-tripe.

Habenaria biforia, RB. Butterfly Orehis. " viridis, RB. Frog Orchis.

Hedera Helix, L. Ivy. Hedysarum coronatium, L. French Honeysuckle. Helianthendui vulgare, L. Rock-rose. Sunflower. Helianthus annuds, L. Sunflower.

" TUBerosts, L. Jerusalem artichoke.

Hellebords niger, L. Christmas Rose.

" FEeTidus, L. Bear's foot. Oxheel. Setterwort.

$" \quad$ viridis, L. Peg-roots.

Helminthia echioides, Gärt. Lang-de-beef. Ox-tongue. Heracleda Sphondylidm, L. Cow Parsnip. Meadow Parsiip. Madnep. Hog-wreed. Clog-weed. Bear's breeeh. Herminid MIONORCHis, RB. Musk Orchis. Herniaria glabra, L. Rupture-wort. Burst-wort. Hesperis matronalis, L. Dame's Violet. Damask Violet.

Queen's Violet. Close Scienees.

" tristis, L. Melaneholy Gentleman. Hieracium, L. Hawk-bit. Hawk-weed.

" Piloselita, L. Mouse-ear.

" adrantiacom, L. Grimm the Collier.

Hierochloe borealis, Rm. Holy-grass.

Hippocripis comosa, L. Horse-shoe-veteh. Unshoe-the-horse. Hippophae Rhamnoides, L. Sea Buek-thorn. Sallow-thorn. Willow-thorn.

Hipreris velgaris, L. Mare's tail. Hordetr, L. Barley. Big. Bear. ", maritimum, L. Squirrel-tail. " nurinum, L. Mouse Barley. Wall Barley. " Pratianse, L. Rie-grass.

Hottonia palustris, L. Water Violet. Bog Featherfoil. Water Milfoil. Water Gilliflower.

Humules Lurules, L. Hop.

Hyacistirus, L. Hyacinth. Jacinth. 
HrDrocharis Morsds rande, L. Frogbit.

Hydrocotrle vuliaris, L. Penny Rot. White Rot. Flookwort. Marsh Pennywort.

Iryexophylum, Sm. Filmy Fern.

HŸoscyayus NiGER, L. IIenbane.

Hroseris mivima, L. Swine Sueeory.

Irpericum Androsanum, L. 'Tutsan. Park-leaves.

" Peirforatum, L. St. John's wort.

" Quadrangulum, L. St. Peter's wort. Hard-hay.

HYPOCHARIS MACUlata, L. Cat's ear.

Hyssopus OFficinalis, L. Hyssop.

IBERIS UMBellata, L. Candy-tuft. amara, L. Seiatiea Cress.

Ilex Aquifolidi, L. Holly. Holm. Hulst. Hulver. Christmas. Impatiens Noli me tangere, L. Touch-me-not. Balsamine. Quick-in-Hand.

Inperatoria Ostruthidi, L. Master-wort.

Inula Conyza, DC. Ploughman's Spikenard. Fleawort.

" DYSenterica, L. Fleabane Mullet.

" Helenidi, L. Elccampane. Elf-doek. Horse-hele.

Seab-wort.

" Crithaoides, L. Golden Samphire.

" PUlicaria, L. Fleabane. Herb Christopher.

Iris Pseudacords, L. Sword Flag. Yellow Flag.

" Florentina, L. Orice-root. Flower-de-Luee.

" FGtidissima, L. Stinking Gladdon. Gladwyn. Ronstbeef.

Isatis Tinctoria, L. Woad.

Isoetrs LACUSTRIS, L. Quill-wort.

Jasione montana, L. Sheep's-bit Seabious.

Jasminum officinale, L. Jessamine.

Juglans REgra, L. Walnut. Freneh-nut.

Juxcus, L. Rush. Seaves.

" Effosus, L. Candlo Rush. Pin Rush.

" squarrosus, L. Goose-eorn. Moss Rush. 
JuNiperus Comunis, L. Juniper.

" Sabina, I. Sarinc.

Lactuca sativa, L. Lettuce.

" vinosa, L. Sleepwort.

Lagurus ovarus, $\mathrm{L}$. Hare's tail.

Laminaria saccharina, Lam. Honcywarc. Sca Belt.

" digitata, Ag. Tangle.

Lamidr amplexicadle, L. Henbit.

, PURPUreum, L. Red Deał-nettle.

" ALbUm, L. White Dead-nettlc. Deaf-, or Blind-ncttlc.

White Archangel.

" Galeobdolon, Crz. Yellow Archangel. Weaselsnout. Yellow Dead-nettle.

Lapsana commenis, L. Nipple-wort.

Lathraa squamaria, L. Toothwort. Clown's Lungwort.

Latirrus Nissolia, L. Grass Veteh.

" Aphaca, L. Yellow Vetehling.

"Macrorrhizus, Wim. Heath Pea.

" Pratensis, L. Tare-everlasting. Vetchling.

" sylvestris, L. Everlasting Pea.

" odoratus, L. Sweet Per.

Laurus nobilis, L. Sweet Bay. Roman Laurel. Lorer.

Lavatera arborea, L. Velvet-leaf. Tree Mallow.

Lavandula Spica, L. Lavender.

"Sroechas, L. Cassidony. Stick-a-dove. French Lavender.

Lecairora tartarea, Aeh. Cudbear.

Lecidea geographica, Hk. Map Lichen.

Ledum Palustre, L. Marsh Cistus.

Lesina, L. Frog-foot. Duek's-meat.

Leontodon Taraxacum, L. See Taraxacum officisale, W. Leondrus Cardiaca, L. Motherwort.

Lepidiud Campestre, RB. Mithridate Pepperwort. Cowcress.

" roderale, L. Bowger's Mustarl. 
Lemidium latifolium, L. Penny Cress. Dittany. Dittander. Pepper-wort.

„ Satrum, L. Town Cress. Garden Crẹss. Passerage. Leccolum estrucar, L. Snowflake. Ligusticum scoticum, L. Lovage. Ligestrum vulgare, L. Privet. Primprint. Lrlidar Caxprdus, L. White Lily. Juno's Rose.

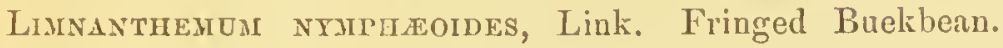
Marsh flower.

Limosella agdatica, L. Mudwort.

Linaria vulgaris, Mneh. Toadflax. Flaxweed.

" Crmbalaria, Mill. Mother-of-thousands. Penny-wort. ,. SPuria, S. Fluellin.

Linosyris vulgaris, Cas. Goldiloeks.

Lindy usitatissindu, L. Flax. Line. Linseed.

" Catharticex, L. Fairy-flax. Mill-mountain.

Listera otata, RB. Twayblade. Bifoil.

Lithospermum officinale, L. Gromwell. Pearl-plant. Liehwale.

" ARvense, L. Bastard Alkanet.

Littorelia lacustris, L. Shoreweed.

LoliUM PERENNE, L. Ray-grass.

" tejclentum, L. Darnel. Irray. Ray. Neele.

Loxicera Caprifolitsi, L. Caprifoly. IIoneysuekle. Lily among thorns.

$"$ Periclymenum, L. Woodbine.

" Xrlostedi, L. Fly Honeysuckle.

Lotes conniculatus, L. Bird's-foot Trefoil. Butter-jags. Crow-toes.

Luxaria biexisis, L. Honesty. Money-flower. Satin-flower. Bolbonae.

Lupinus, L. Lupine.

Lezula sylvatica, B. Woodrush.

\# CAmpestris, B. Cuckoo-grass.

Lycinis Flos cucoli, L. Ragred Robin. Cuckoo-flower, or -Gilliflower. Meadow Pink. Meadow Campion. " Gitingo, Lay. Corn Cockle. Gith. 
Lrcinis Viscaria, L. Catchi-fly.

" Chalcenoyica, L. Bristol Flower. Cross of Jeru. salem. Flower of Constantinople.

" coronaria, L. Rose Campion.

Lycoperdon, L. Fist-ball. Puek-fist. Fuss-lall. Puff-ball. Lrcopodium clavatusi, L. Wolf's elaw. Club-mose.

" Alpindu, L. Heath Cypress.

" Selago, L. Fir-moss.

Lycopsis arvensis, L. Wild Bugloss.

Lrcopds europeds, L. Gipsy-wort. Water Horehound.

Lysimachia vUlgaris, L. Loosestrife.

" Nemorum, L. Yellow Pimpernell.

" Numuluaria, L. Herb Twopenee. Moneywort. Twopenny-grass.

Lythrun hyssopifolidm, L. Grass Poley.

" Salicaria, L. Purple Loosestrife.

Maianthemum bifolum, DC. One-blade.

Malva rotundifolia, L. Dwarf Mallow.

" Sylvestris, L. Mallow. Round Doek. Maule. Hoekherb. Mauve.

", moschata, L. Musk Mallow.

Marasmus oreades, Fries. Champignon. Pixie stools.

Marchantia polysiorpha, L. Liverwort.

Marrubiuy volgare, L. Horehound.

Matricaria Chamomilla, L. Dog's Chamomile. Maithe. Mather. Maudlin. Mayweed.

Matthiola incana, RB. Stock-Gilliflower. July flower. Stoek. Meconopsis Canerica, V. Welsh Poppy.

Medicago sativa, L. Lueeru. Mediek. Suail Clover. Sainfoin. Holy hay.

" lupulina, L. Nonsueh. Shamroek. Blnek-seed.

" maculata, Willd. Heart Clover.

Melajprrum pratense, L. Cow-wheat. 
Meinotrós officinalis, L. Melilot. Hart's Clover. King's Clover. Plaister Clover.

Melissa officinalis, L. Balm.

Meittis Melissorirylum, L. Bastard Balin.

Mentha sylvestris, L. Horse Mint. Brook-, or Water-Mint. " viridis, L. Spear Mint. Garden Mint.

piperita, L. Pepper Mint.

citrata, Ehr. Bergamot Mint.

Pulegiur, L. Pennyroyal. Pudrling-grass. satrva, L. Garden Mint.

Menyantues trifoliata, L. Buekbean. Bogbenn. Marsh Trefoil.

Mienziesia polifolia, Sm. St. Daboee's Heath. Irish Heath.

Mercurialis perennis, L. Dog's Mereury.

" Annua, J. Freneh Mereury.

Merulius lacrimans, Wulf. Dry-rot.

Miespilus gerianic4, L. Medlar.

Meum athamanticum, Jae. Baldmoney. Mew. Bearwort. Spikikenel.

Milium effusum, L. Millet.

Monaliza fistulosa, L. Bergamot.

Moyotropa Hypopitys, L. Yellow Bird's-nest. Pine-sap. Munta fontana, L. Water-Blinks, or -Chiekweed. Blinking Chiekweed.

Morchella esculenta, P. Morel.

Mores vigra, IV. Mulberty.

Muscari racemosum, M. Grape Hyacinth.

Myosotis Palustris, With. Forget-me-not. Mouse-ear Seorpion-grass.

Mrosurus minimus, L. Mousetail. Blood-strange.

Mrrica Gale, L. Duteh Myrtle. Gale. Bogr Myrtle. Sweet Willow. Candleberry.

Mrriopiyluum, L. Water Milfoil.

Myrimis odorata, Seop. Sweet Chervil. Sweet Cicely. Myrtus comanis, L. Myrtle. 
Narcissus Pseddonarcissus, L. Daffodil. Laent-lily. Cirowbells. Affadyl.

$" \quad$ miflorus, Cint. l'rimrose Peerless.

$"$ JokgUilla, I. Jonquil.

Nandos stiricta, L. Matgrases. Wirebent.

Natemecium ossifragum, Huds. Bog or Marsh Asphodel.

Lameashire Asphodel.

Nasturtiuy officinale, RB. Water-eress.

Neottia Nides avrs, L. Bird's nest.

Nepeta Glechoma, Benth. Ground Ivy. Alehoof. Cat's foot. Hove. Gill. Haymaids. Tunhoof.

" Cataria, L. Cat Mint. Nep.

Nerine sarniensis, W. Guernsey Lily.

Nigelda damascena, L. Devil-in-a-bush. Catharine's flower.

Love-in-a-mist. Bisbop's wort. Fennel-flower.

Kiss me twiee.

Nuphar luteda, Sm. Yellow Water-lily. Brandy-bottle. Candoek.

Nymphea ALba, L. White Water-lily.

Ocynum basilicum, L. Sweet Basil.

CEnanthe fistulosa, L. Water Dropwort.

" crocata, L. Water Hemloek. Dead-tongue.

" Phellandridui, Lam. Horse-bane.

Genothera biennis, L. Evening Primrose.

Omphalodes verna, Mn. Venns' Navel-wort.

Onobrychis satira, L. Sainfoin. Freneh-grass. Coek's eomb.

Ovonis arvensis, L. Rest-harrow. Ground Furze. Stry-plough.

Oropordon Acanthium, L. Scotel Thistle. Cotton Thistle.

Silver Thistle.

Opiroglossdir vulgatum, L. Adder's tongue.

Ophrys al'ifera, Huls. Bee Orehis.

3 aranifera, Huds. Spiler Orehis.

" FUCIFERA, Sin. Drone Orehis.

" muscifera, Huds. Fly Orehis.

Orcirs Morio, L. Goose and Goslings. Grudergosses. 
Orchis militaris, L. Soldier Orchis.

" Masctia, L. Long purples. Stander-wort.

„ Maculata, L. Dead-man's-fingers. IIand Orchis.

" hrrcrna, Scop. Lizard Orchis.

" Latifolia, L. Salep.

Origanum velgare, L. Marjoram. Organy.

Orxithogalum PYrenaicum, L. French Sparrow-gi'ass.

" umbellatem, L. Star of Bethlehem. Eleven-o'clocklady.

Ornithopds peritusillus, L. Bird's foot.

Orobanche major, L. Broomrape.

Orobus, see Vicia.

Osmunda regalis, L. Osmund-royal. Flowering-fern. Herb Christopher.

Oxalis Acetosella, L. Wood Sorrel. IIallelujah. Gowkmeat. Cuckoo's bread. Cuekoo Sorrel. Wood Sower. Stub-wort. Stab-wort.

Oxtria reniformis, Sm. Mountain Sorrel.

Prenia corallina, L. Peony. Marmaritin. Chesses.

„Moutan, L. Moutan.

Palmella cruenta, Agh. Gory Dew.

Panicum crus galli, L. Coek's-spur-grass.

Papaver Rifeas, L. Corn or Red Poppy. Corn Rose. Cop

Rose. Red-weed. Canker Rose. Headache. Head-

warke. Joan Silver-pin. Cheese-bouls.

" somninerum, L. White Poppy. Cheesebouls. Mawseed. Parietaria officinalis, L. Pellitory-of-the-wall. Lichwort. Paris quadrifolia, L. Merb Trulove. One-berry. Herb Paris.

Four-leaved-grass. Leopard's bane.

Parnassia palustris, L. Grass of Parnassus.

Pastixaca satrya, L. Parsnip.

Pedicelaris sylvatica, L. Lousewort. Red Rattle.

Peplis Pontula, L. Water Purslane.

Petroselnum sativuar, L. Parsley.

" Segetur, L. Corn Hone-wort. 
Peucedandm ormenale, L. Brimstone-wort. Sulphur-wort. Hog's Fennel. Har'strong. Spreusidany. Cammock.

" Palustre, Mn. Milk Parsley.

Phalaris canamiexsis, L. Bird-seed. Canary-grass.

Phallus impunicus, L. Stinkhorn.

Prascurr, L. Earth Moss.

Piraseolus vulgaris, L. Freneh Bean. Kidney Bean.

" Multiflorus, W. Scarlet runner.

Philadelphus coronaria, L. Syringa.

Phleum pratense, L. Timothy-grass.

Phlomis fruticosa, L. Jerusalem Sage.

Physalis Alkekengi, L. Winter Cherry.

Pildlaria globulifera, L. Pill-wort. Pepper-grass.

Pimpixella Saxifraga, L. Burnet Saxifrage. Pimpinell. Anisury, L. Anise.

Pinguicula vulgaris, L. Butterwort. Rot-grass. Yorkshire Saniele. Bog Violet.

Pinus syluestris, L. Scoteh Fir. Riga Pine.

" abies, L. Spruee Fir.

” PICEA, L. Silver Fir.

Piscar sativum, W. Pea.

" maritimum, L. Sea Pea.

Plantago lanceolata, L. Ribwort Plantain. Kemps. Coeks. " MEDIA, L. Lamb's tongue.

" Coronopus, L. Star of the Earth. Hart's horn.

" गIAJOR, L. Plantain. Way-bread.

Platanus, L. Plane. Platane.

Poa fluitans, Scop. Flote-grass.

Polemonium ceruleedr, L. Jacob's ladder. Makebate. Greek Valerian.

Polycarpon tetraphillum, L. Allseed.

Polygala vul.garis, L. Rogation flower. Gang flower. Procession flower. Mlilk-wort. Cross flower.

Polygonatum hultiflondi, All. Solomon's seal. Lady's seal. 
Polygoxum aviculare, L. Knotgrass. Ninety-knot. Swine's grass. Sparrow-tongue. Bird's tongue. Pink-iveed. Centinode.

, Fagopyrum, L. Buekwheat. Brank. Convolvulus, L. Black Bindweed.

" Bistorta, L. Bistort. Snake-weed. Toviee-writhen. Adder-wort. Red-legs. Osteriek.

" Persicaria, I. Persiemia. Peaeh-wort. Red-shanks.

" Hrdropiper, L. Arsmart. Culrage. Ciderage. Water

Peppcr. Lake-weed. Red-knees.

Polypodiun velgare, L. Common Polypoily. Wall-fern. Oak-fern.

". Pinegopteris, L. Beech-fern.

" Dizopteris, L. Oak-fern.

Polyporus, Fries. Canker.

fomentarius, Fries. Amadou. Touehwood. Popelus alba, I. Abele. White Poplar.

" tremula, I. Aspen.

" Nigra, L. Black Poplar.

" " var. Fastigiata, Dsf. Lombardy Poplar.

Porphyra laciniata, Ag. Laver.

Portulaca oleracea, L. Purslane.

Potamogeton, L. Pond-weed.

" DExsus, L. Frog's Lettuee.

" Natans, L. Teneh-iveed.

Potentilla Reptans, L. Cinquefoil. Five-leaf. Five-fingergrass.

"Tonyextilla, L. Tormentil. Blood-root. Septfoil. " Fragariastrum, Ehr. Barren Strawberry.

" avserixa, L. Silver-weed. Goose Tansey.

" Comarum, L. Purple-wort.

Poterium Saxguisorba, L. Burnet. Pimpinell. Salad Burnet. Prexantiles uuralis, L. Wall Lettuee.

Prisula veris, L. a. P'rimrose. Petty Mullcin. Primerole.

$\begin{array}{ll}" & \quad \text { b. Cowslip. Herb Peter. Paigle. Palsy-wort. } \\ & \quad \text { e. Oxlip. Polyauthus. }\end{array}$


Primola Almcula, L. Bear's ears. Monntain Cowslip.

$"$ harinosa, L. Bird's eye.

Prunelda vulgairs, L. Hook-heal. Self-lecal. Carpenter'g herb. Sickle-wort.

Prunus comyunis, Huds. v. spinosa, Sine. Blackthorn. Skeg. Suag.

" $\quad$ v. insititia, Bullaee. Damson. Plum.

" Avium, L. Gean. Mazzards. Merry.

" ARMENiACA, L. Aprieot.

" Pades L. Bird Cherry. Heg-, or Hack-berry.

" Laurocerasus, L. Laurel. Cherty Laurel.

" lusitranica, L. Portugal Laurel.

Psama arenaria, P.B. Maram. Halm. Matweed. Stare.

Pteris aquilina, L. Brake. Braeken.

Puccinia graminis, P. Mildew.

Pulmonaria officinalis, L. Lungwort. Bugloss Cowslip. Jerusalem Cowslip.

Pyrethrum Parthenidi, L. Feverfew. Bertram. Mayweed. Maithes.

Pyrola, L. Wintergreen.

, SECUNDA, L. Yevering Bells.

Pyrus communis, L. Pear. Choke Pear.

"Malus, L. Apple. Crab. Codlin. Wharre.

, Aria, Sm. White Berm.

" ToRminalis, Sm. Sorb. Wild Service. Swallow Pear.

"Aucuparia, G. Rowan. Mountain Ash.

" domestica, Sm. Service. Chequer-tiee. Corme.

Quercus Rogur, L. Oak.

"Ilex, L. Holm Oak. Evergreen Oak. Ilex Oak.

" Ceris, L. Turkey Oak.

"

" var. Luecombe Oak.

Radrola Millegraya, L. All-seed. Flax-seed.

Ranunculus aconitifolius, L. Fair Maids of France.

" AQuaticus, L. Water Clowfoot.

" Butboses, L. St. Anthony's Rape, or Turnip.

" Lingua, L. Spear-wort. 
Ranunculus Flaméla, L. Bane-wort.

" Ficaria, L. Pile-ivort. Lesser Celandine.

" scelerates, L. Celery-leaved Crowfoot.

" Auniconus, L. Goldiloeks.

", ACris, L. Crowfoot. Butterenp. Gold-cup. Goldknoppes. King's-eup. Crazy.

anvensis, L. Hunger-weed.

Rapuanus Rapilanistrum, L. Jointed Charloek. Runeh. Rabone.

, Satrvus, L. Radish.

Reseda lutea, L. Base Roeket.

" Luteola, L. Weld. Yellow-weed. Dyer's Rocket.

, odorata, L. Mignonette.

Rhaunes cathartices, L. Buekthorn. Mart's-thorn. Rhineberries. Rain-ber'y thor'n.

" Fraxgula, L. Blaek Alder. Berry Alder. Butcher's Priek-wood.

" Alaternus, L. Barren Privet.

Rнйу, L. Rhubarb.

Ruinantues crista gall, L. Tellow Ratule. Penny-grass. Rattle-box.

Rhodomenia paluata, B.V. Dulse. Ribes Grossclaria, L. Goosebery. Thape. Feabe.

" Rubrum, L. Currant. Garnet-berry. Raisin-tree.

, Nigrum, L. Blaek Currant. Squinauey berry. Grzles. Robicia Pseudacacia, L. Aeaeia.

Roccella tinctoria, L. Arehal. Orchil. Litmus. Cork. liosa pimpinellifolia, L. Buinet Rose.

, rumiginosa, L. Sweet-briar. Eglantine.

" Canisa, L. Dog Rose. Hip Rose.

RotThoklda incervata, L. Hard-grass. liubia tinctorum, W. Malder. Warenee. liubes Casius, L. Dewbery. Theve-thorn.

" IDAUS, L. Raspberry. Framboise. Hindlserry.

" Frutricosus, L. Biamble. Blackberry. Bumblekite. Seald-berry. 
Rubus Cimamasrones, L. Cloud-berty. Naops.

,. Saxatilis, L. Knot-beity.

Rumex, L. Doek.

" Sanguineus, L. Blood-wort. Bloody Dock.

, Pulcier, L. Fildle Doek.

"Acetosa, L. Sorrel. Sharp Doek. Green-sauce.

" Acetosella, L. Sheep Sorrel.

" овтUsifolius, L. Butter Doek.

" Patientia, L. Monk’s Rhubarb.

Ruppia maritima, L. Sea-grass. Tassel-grass.

Ruscus aculeatus, L. Buteher's broom. Box Holly. Knee Holly. Pettigrew.

" Racemoses, L. Alexandrian Laurel.

Ruta graveolens, L. Rue. Herb of Graee.

Sagina procunbens, L. Pearl-wort.

Sagittaria safittifolia, L. Arrow-head.

Salicornia herbaced, L. Glass-wort. Frog-grass. Sea Grape. Salt-wort. Marsh Samphire. Crab-grass.

SaLIX, Willow.

$"$ Fragilis, L. Craek Willow.

" ALBA, L. White Willow.

" viminalis, L. Osier. Withy.

" Caprea, L. Sallow. Palm.

" herbacea, L. Dwarf Willow.

" BabYLONICA, L. Weeping Willow.

Salsola Kali, L. Sowd-wort. Priekly Glass-wort.

Salvia of ficinalis, L. Sage.

" pratexsis, L. Meadow Clary.

" verbenaca, L. Wild Clary.

" Sclarea, L. Clary. Sebright. Clear-eye.

Sajrbeces Ebelus, L. Dwarf Elder. Dane-wort. Wall-wort.

NIGRs, L. Elder. Bore-tree.

Samolus Valerand, L. Brook-weed. Water Pimpermel.

Saxguisorba ofricisalis, L. Great Burnet. Burnet Bloodwort. 
Sanicula mulopaca, L. Simiele. Self-heal.

Sapoxalia officinalis, L. Soqp-wort. Fuller's lerb. Bruisc-wort.

Sargassum vulgare, Ag. Gulf-weed.

Sarothannes scoparrus, Wim. Broom.

Satureja ilortensis, L. Savoury.

SAxifraGa, L. Saxifrage. Thirlstane. Stonebreak.

" Tridactylites, L. Nail-wort. Whitlow-grass.

" vimiosa, I. London Pride. St. Patrick's-èabage.

Pratling Parnel. None-so-pretty. Nancy-pretty.

Scabiosı, L. Scabious.

" sccciss, L. Devil's-bit. Forebitten More. Blue-eaps.

, Columbaria, L. Small Scabious.

" Arvensis, L. Blue-caps.

Scandix Pecten, L. Venus' eomb. Shepherd's neelle.

Devil's darning-needles. Lady's comb. Crow-, or

Crake-needles.

Scrlla verina, Huds. Star Hyaeinth.

" nutans, Sm. Bluebell. Harebell. Squill. Crowleeks. Culverkeys.

Scrrpus Cespritosus, L. Deer's hair.

", Lacustris, L. Bulrush. Pole-rush. Mat-rush.

Scleranthus axyuds, L. Knawel.

SColopexdriom vulgare, Gärt. Hart's tongue.

Scorzonera edulis, Mr. Viper-grass.

Scrophularia nodosa, L. Kernel-wort. Bull-wort. Brownwort.

" aquatica, L. Bishop's leaves.

Scutellaria galericolata, L. Skull-eap. Helmet flower.

" Minol, L. Hedge Hyssop.

Scyphophorus prxidatus, IIk. Cup Liehen. Cup Moss.

Secale cereale, L. Rye.

Sedua Rhodiola, DC. Rose-root.

" 'Telepinum, L. Orpine. Livelong. Liblong. Midsumme1'-mell.

" ALIUß, L. Worm-grass. 
Sedur acre, L. Wall Pepper. Jird's bread. Jack-of-the buttery. Pricket. Pepper-crop. Stonc-crop. ReFlexum, L, Stonor. 'Trip-madam.

Sempervivum tectorum, L. Houseleck. Jupiter's hoard. Joubarb. Aycgrecn.

Seneriera Coronopus, Poir. Swine Cress. Wart Cress. Senecio vulgaris, L. Groundscl. Simson.

"JАСовеA, L. Ragwort. Seggrum. Stagger-wort.

Staver-wort.

" Saracenicus, L. Saracen's Consound.

Serratula tinctoria, L. Saw-wort.

Sisleria cerdelea, Scop. Moor-grass.

Sherardia arvensis, L. Field Madder. Spur-twolt.

Sibbaldra procumbens, L. Scotch Cinquefoil.

Sibthorpia europera, L. Cornish Money-wort. Penny-wort. Silads pratensis, B. Meadow Saxifiage.

Strene acaulis, L. Moss Campion. Cushion Pink.

" inflata, L. Ben. Bladder Campion. Knap-bottle. Spatling Poppy.

" alaritima, L. Witches' thimble.

Sinapis, L. See Brassica.

Sison Amomun, L. Stone Parsley. Hone-wort.

Sismmbrium OFficinale, Scop. Hedge Mustard. Bank Cress. Crambling Rocket.

" Irio, L. London Roeket.

, Sophita, L. Flixweed.

Sidi latifolida, L. Water Parsnip.

, Sisarum, L. Skirret.

Sirrnium Olus atrua, L. Alexanders. Horsc Parsley. Stanmareh.

Solandm Dulcamara, L. Bittersweet. Woody Nightshade.

Felon-wort.

", Nigrum, L. Petty Morel. :

, tuberosun, L. Potato.

" Lrcorersicun, L. Gold apples. Love apple. Tomato.

Solidago Virga aurea, L. Gollen-rod. 
Soxchos oleraceds, L. Sow 'Thistlo. Hare's Lettuee. Spatranidm ramosum, L. Bur Reed. Bedo Sedge. Srartina stricta, Sm. Cord-grass. Spart-, or Spurt-grass. Spergula arvensis, L. Spurry. Franke. Yarr. Spergularia rubra, Pers. Sand Spurry. Sitignum, L. Bog Moss. Spirea Ulmaria, L. Meadow-sweet. Mead-wort. Queen of the mead. Bride-wort.

, Filipendula, L. Diop-wort.

Spiranthes autumalis, Rieh. Lady's tresses. Stachrs Betonica, Benth. Betony. ," Germanica, L. Wound-wort.

" sylvatica, L. Red Arehangel. Hedge Dead-nettle. " Palustris, L. Clown's Allheal.

Staphylea pinnata, L. Bladder-nut. Statice Limonium, L. Sea Lavender. ,, Armeria, Sm. See Armeria. Stellaria media, L. Chiekweed. ,, Holostea, L. All-bone. Stiteh-wort. Sticta Pulmonaria, Hk. Tree Lungwort. Stipa pennata, L. Feather-grass. Stratiotes aloides, L. Water-soldier. Knight's wort. Subularia aquatica, L. Awl-wort. Symphoria racemosa, Ph. Snow-berry bush. Symphytum officinale, L. Comfrey. Knit-baek. Srringa volgaris, L. Lilae. Pipe-tree. Syring.

Tamarix gallica, L. Tamarisk. Tamos comunis, L. Black Bryouy. Lady's seal. Tanacetur vulgare, L. Tansy. 'Taraxacus officinale, W. Dandelion. Priest's erowu. Swine's snout. Pissabed. Blow-ball.

Taxus baccata, L. Yew. Palm. Teesdali nudraulis, RB. Shepherd's Cress. Teucrium Scorodonia, L. Wood Sage. Wood Germander. Hind-heal. 
Teucrium Scordum, L. Water' Germander.

" Chandedrys, I. Germander. Iforseelire.

" Botrrs, L. Oak of Jerusalem.

Thalictrua flavum, L. Meadow Rue. Fen Rue.

'Thesiun linophyludi, I.' Bastard 'Toaiflax.

Thlaspi arvense, L. Penny Cress. Mithridate Mustard.

Thraus Serpyluum, I. Thyme. Hill Thyme. Wild Thyme.

Pell-a-mountain. Mother of Thyme.

" vulgaris, L. Garden Thyme.

Tilia europan, L. Lime-tree. Linden. Teil-tree. Bast-tree. Torieldia palustris, Huds. Seottish Asphodel.

Tordilium maximum, L. Hart-wort.

'Tragopogon i'ratensis, L. Goat's beard. Go-to-bed-at-noon.

Noon-flower. Noontide. Buek's beard. Joseph's

flower.

" Porrifolius, I. Salsify. Star of Jerusalem. Napat-noon.

Trapa natans, I. Saligot.

Trenella Nostoc, L. Fallen Stars. Nostoe. Will of the Wisp.

, arborea, Sm. Fairy butter.

Trichomanes radicans, Sw. Bristle-fern.

Trientalis europea, I. Winter-green Chiekweed. Trifolium arvense, L. Haresfoot Clover.

" Pratense, L. Meadow Clover. Honeysuckle.

, IYBRIDUM, I. Alsike.

" FRAGIFERUM, I. Strawberry Clover.

" incarnatum, L. Crimson Clover.

" agrarium, L. Hop Clover.

" Repens, L. Dutch Clorer.

Triglochin palustre, L. Arrow-grass.

Trigonella ornithopodioides, DC. Bird's foot.

Trinia glaberrina, L. Hone-wort.

Triticun RePens, L. Coueb. Quiteh grass.

" Caninum, Huds. Dog grass.

" Spelta, I. Spelt. Stareh eorn. 
Trollius europaus, L. Globe flower. Troll flower. Loeken Gowan.

TropдzOLUM MAJUs, I. Sturtion.

Tuber cibaridu, Sib. Earth-ball. Truffe.

Tulira, L. Tulip. Turk's eap.

Tussilago Petasites, L. Butterbur Coltsfoot. Pestilenee weed. " Farfara, L. Coltsfoot. Asses foot. Bull's foot. Folefoot. Cough-wort. Horse-hoof.

Trpira latifolia, L. Reed-mace. Bull-segg. Dunse-down. Cat's tail. Water toreh. Marsh beetle. Club Rush.

Ulex europeus, L. Furze. Thorn Broom.

Uliug Campestris, Sm. Elm-tree.

", Montana, Sm. Wych Elm. Wyeh Hazel.

Ulva latissima, Grev. Laver.

Unibilicus, DC. See Cotyledon.

Urtica dioica, L. Nettle.

$" \quad$ urens, L. Sting Nettle.

" Pilulifera, L. Roman Nettle.

Ustilago segeturi, Fries. Smut.

Utricularia vulgaris, L. Bladder-wort. Hooded Milfoil.

Vaccinium Myrtillus, L. Bilberry. Whortle-berry. Hurtleberry. Wim-berry. Blaek-worts.

$" \quad$ vliginosuar, L. Blea-berry.

Vaccinum Vitis Ina, L. Cow-berry.

" Oxycoccos, L. Cran-berry. Bog-berry. Bog-wort.

Fen-berry. Marsh-worts.

Valeriaxa officinalis, L. Valerian. Setwal. Capou's tail.

Cut-heal. Herb Benuett.

Valemianella olitoria, Poll. Lamb's Lettuee. Corn salad. White potherb.

Verbascum Tinarsus, L. Mullein. Hagtaper. 'Toreh. Higtaper. Hare's beard. Jupiter's staff. Bulloek's Lung wort. Velvet Doek.

" Blattaria, I. Moth Mullein. 
Vribena officinatis, L. Vervain. Simpler's joy. Holy berl.

Juno's tears. Pigeon's grass.

Veronica ofricinalis, L. Ground-heele.

" Serpyldifolia, L. Paul's Petony.

" Beccarunga, I. Brooklime. Water Pimpernel.

" Cinamadrys, L. Speedwell. IBlue Bird's-eye.

" Agrestis, L. Germander Chiekweed.

" hederifolia, L. Morgeline. Winter-weed. Hen-bit.

Viburium Lantaxa, L. Wayfaring-tree. Whitten-tree. Lithytree. Mealy-tree.

" Opulos, L. Guelder Rose. WVater Elder. Rose Elder. Snow-ball.

"Tinus, L. Laurestinus.

Vicia sativa, L. Veteh. Fiteh.

" Faba, L. Horse Bean.

, orobus, DC. Bitter Veteh. Kipper nut. Cormeille.

" Lathyroides, L. Strangle-tare.

" hirsuta, K. Tine-tare.

Vinca major, L. Periwinkle.

Viola odorata, L. Sweet Violet. Mareh Violet.

" Canina, L. Dog Violet.

" Tricolor, L. Pansy. Heartsease. Herb Trinity. Three faees under a hood. Faney. Flamy. Kiss me. Love in idle.

Viscum albun, L. Mistletoe.

Vitis Vinifera, W. Vine.

Xanthicm strumarium, L. Bur-weed. Burdoek Clot-meed. Diteh-bur. Louse-bur.

Zannichellia palustris, L. Horned Pond-need. Zostera makina, L. Grass-wraek.

THE END.

Wellcome Library

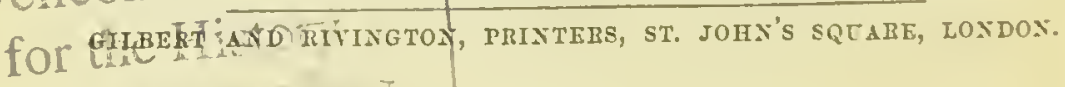
and Urr 



